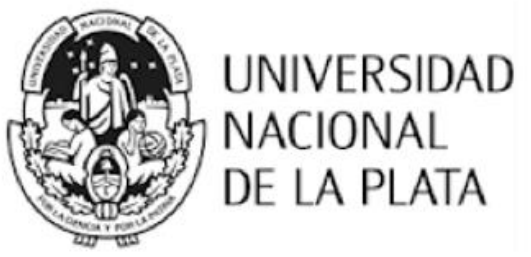

Facultad de Humanidades y Ciencias de la Educación MAESTRÍA EN ESCRITURA Y ALFABETIZACIÓN UNIVERSIDAD NACIONAL DE LA PLATA

\title{
La utilidad de los conocimiento del nombre de la letra para la adquisición del sistema de escritura
}

\author{
Tesis presentada para obtener el grado de \\ Magíster en Escritura y Alfabetización \\ Presenta \\ Giulianny Russo Marinho \\ Profesora en Pedagogía \\ Directora de tesis \\ Mónica Alvarado Castellanos \\ Doctora en Ciencias con Especialidad em Investigación Educativa
}

La Plata, Argentina

Septiembre de 2018 


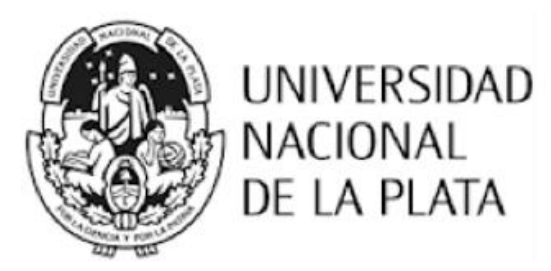

Facultad de Humanidades y Ciencias de la Educación

MESTRADO EM ESCRITA E ALFABETIZAÇÃO

UNIVERSIDAD NACIONAL DE LA PLATA

\title{
A utilidade do conhecimento do nome da letra para a aquisição do sistema de escrita
}

\author{
Tese apresentada para obter o grau de \\ Mestre em Escrita e Alfabetização \\ Apresenta \\ Giulianny Russo Marinho \\ Licenciada em Pedagogia \\ Orientadora de tese \\ Mónica Alvarado Castellanos \\ Doutora em Ciências com Especialidade em Investigação Educativa
}

La Plata, Argentina

Setembro de 2018 
Folha de aprovação 
À minha mãe, que plantou em mim a curiosidade e o desejo insaciável de aprender. Que viu nascer o sonho desse mestrado, vibrou com meu ingresso nele, mas que, infelizmente, não está aqui para celebrar esse momento. 


\section{Agradecimentos}

À Mónica Alvarado, minha diretora, que com generosidade acolheu minhas inquietações e que com muito rigor me orientou nesse caminho. Para além de todos os ensinamentos teóricos, aprendi também ao observar sua postura séria e comprometida com a pesquisa científica. Agradeço a oportunidade que me ofereceu de desenvolver-me com você. Minha profunda admiração e carinho.

À Mirta Castedo, cuja militância possibilitou realizar o meu sonho: estudar e pesquisar junto a tão importantes pesquisadoras; aprofundar e construir de forma acadêmica saberes que dificilmente poderia conquistar aqui no meu país, em que a pesquisa de corte psicogenético ainda não adentrou consistentemente a universidade, em especial, na área da leitura e da escrita.

Aos professores desta maestria, razão pela qual a busquei. Delia Lerner, Ana María Kaufman, Mirta Torres, Flora Perelman, Marina Kriskausky, Mirta Castedo, Mónica Alvarado, Emília Ferreiro e tantos outros: obrigada pela generosidade com a qual nos brindaram durante as aulas, as leituras cuidadosas dos materiais e a abertura ao diálogo e à reflexão.

À Mariel Rabasa, minha tutora, por toda a parceria desde o início desta jornada, pela atenção e paciência dedicadas.

À Belén e à Eugénia, pelos pacientes contatos telefônicos e eletrônicos e a pronta disponibilidade para esclarecer a tantas dúvidas.

Agradeço a Norma Fernández Ortega, pela preciosa ajuda na análise dos dados, e ao IME-USP (Instituto de Matemática e Estatística da Universidade de São Paulo), pela oportunidade de assistir as aulas de Estatística, como aluna especial, e me aprofundar um pouco mais neste precioso universo.

A todos os companheiros da $4^{a}$ Cohorte da Maestría com quem tive o prazer de caminhar nessa jornada. Uma oportunidade a convivência diária com as chicas de Uruguai, Córdoba, Rosário, Patagônia, La Plata, Buenos Aires e de outras partes de São Paulo. Foi uma experiência incrível conhecer tanta gente sabida que dedica suas vidas à escola. Às queridas companheiras da $5^{a}$ Cohorte da Maestría, pela minha adoção em seus/nosso lindo grupo: Adrianna Nunez, Caroline Rezende, Debora Vaz, Isis Nogueira, Natália Raphaela e Priscila de Giovani.

Agradeço, especialmente, às minhas companheiras e amigas Christiane Nakamura e Miruna Genoino, pelas caminhadas até a universidade, a via sacra às livrarias, os sanduíches de atum e as empanadas nossas de cada dia. Os vinhos (que eu tomava tudo), as risadas, os 
longos papos e o sonho compartilhado. Obrigada pela amizade e por todo amor e cuidado a mim dispensados nessa linda jornada. Meu agradecimento e minha doce lembrança desses momentos vividos.

Agradeço à Heloisa Magri e Andrea Ayres por terem por tantas vezes acolhido minhas angústias e me apresentado os caminhos para esta maestria.

À Escola da Vila, por ser tão inspiradora e estruturante em minha formação. Pelo apoio tanto financeiro quanto o de possibilitar minhas ausências na sala de aula nos períodos presenciais. Meu agradecimento, reconhecimento, admiração e amor pela Escola e por cada pessoa dentro dela.

À Andrea Luize, minha primeira grande mestra, cujo brilho no olhar acendeu o meu para a didática da língua escrita, em especial, para a alfabetização inicial. Meu profundo carinho e admiração.

A todos os alunos, com os quais pude aprender ao escutar seus pensamentos, suas reflexões e seus saberes. Foi o que aprendi com vocês que me mobilizou a buscar as respostas para algumas das inquietações e indagações contidas neste trabalho.

Agradeço a todas as escolas que abriram suas portas e a todas as crianças que participaram desta pesquisa, revelando seus saberes sobre a língua escrita. Agradecimento especial à Dona Fátima, pela confiança na seriedade do meu trabalho e por ter me encantado com sua bravura e dedicação à educação pública.

A meus pais, Julio e Edineide, e meus irmãos, Neto e Karol, por serem a minha mais fiel torcida, por sempre acreditarem em minhas potencialidades, mais até do que a realidade permite.

Ao meu querido filho, Antonio, por todas as vezes que precisou ser paciente e esperar pelo colo, pelo peito, pela brincadeira, pela presença. À minha sogra, Ana, que foi uma grande parceira e com quem pude contar para suprir meu filho de todo o amor e os cuidados que ele precisava enquanto me dedicava ao estudo e às reflexões transcritas nesse material, bem como nos acompanhando pela Argentina e México para que eu pudesse estar presente em momentos importantes dessa maestria.

Por fim, a meu marido, André. Meu amigo, meu parceiro e meu amor. Por sonhar junto comigo esse e tantos outros sonhos, por seu apoio irrestrito, pelas minhas ausências e pela ajuda concreta, eficiente e paciente com todo o Excel, e por, reiteradas vezes, me ajudar com todos os conceitos estatísticos e sua importância nesse trabalho. Obrigada. 
- Mas Mónica, isto que estamos "descobrindo" não é óbvio? Esses resultados... você já não os sabia?

- La mejor investigación la hace un experto, no un ingenuo. ¿Cómo se puede aportar a una teoría, si no dominas la teoría? ¿Cómo puedes anticipar una buena hipótesis si no conoces las hipótesis que hay y cómo se han trabajado? Yo lo intuía, yo sabía que había cosas importantes, sabía lo que habian dicho otros desde otras perspectivas, sabía también lo que se decía desde mi modelo. Mas hay una diferencia muy grande entre estas explicaciones y lo que decía mi modelo. Yo tenía una intuición muy grande, tenía que probarlo y es esto lo que hacemos.

(Transcrição de uma sessão de orientação. Querétaro, julho de 2016) 


\section{Resumo}

Pesquisas de natureza cognitivista apontam como fundamental o conhecimento do nome da letra para a aprendizagem da leitura e da escrita, considerando-o um pré-requisito no processo de alfabetização. No entanto, pesquisas de natureza psicogenética marcam que a utilização da informação (nome da letra) está condicionada pela maneira com que a criança entende o funcionamento do sistema de escrita. Nesse sentido, o objetivo desse trabalho foi investigar a relação entre identificar as letras por seus respectivos nomes e a possibilidade de utilizá-las pertinentemente em contextos de escrita e de completar palavras, observando a influência exercida pela motivação fonológica das letras. Solicitamos a participação de 48 crianças pré-alfabéticas, no período fonetizante, entre 5 e 6 anos, que frequentavam a última etapa da educação infantil, em unidades escolares públicas da região central de São Paulo. Organizamos as crianças em 3 grupos de 16 integrantes, segundo o nível de escrita (silábico sem valor sonoro convencional, com valor sonoro convencional, e silábico-alfabético). Em entrevistas individuais, as crianças realizaram três tarefas: identificação de letras fora de contexto, escrita de palavras e completar palavras desprovidas da letra inicial. Os resultados indicam que o efeito da motivação fonológica ligada ao nome da letra difere entre as diferentes tarefas, ou seja, pode influenciar positivamente em algumas e negativamente em outras, variando também segundo o nível conceitual de cada criança. Realizamos análise multivariada para determinar: se identificar letras influencia na tarefa de escrita e de completar palavras; a influência do nível conceitual para identificar, escrever e completar palavras; e a influência da motivação fonológica no desempenho infantil. Os resultados indicam que as possibilidades da criança para utilizar e integrar informações para escrever e completar palavras não dependem do conhecimento do nome da letra.

Palavras-chave: motivação fonológica; identificação de letras; nível de escrita. 


\section{Resumen}

Las investigaciones de naturaleza cognitivista señalan que es fundamental el conocimiento del nombre de la letra para el aprendizaje de la lectura y de la escritura, considerando este saber cómo un prerrequisito en el proceso de alfabetización. Sin embargo, investigaciones de naturaleza psicogenética, marcan que la posibilidad de utilizar la información está condicionada por la manera que el niño entiende el funcionamiento del sistema de escritura. En este sentido, el objetivo de este trabajo fue investigar la relación entre identificar las letras por sus respectivos nombres y la posibilidad de utilizarlas adecuadamente en contextos de escritura y de completar palabras, observando la influencia ejercida por la motivación fonológica de las letras.

Solicitamos la participación de 48 niños pre-alfabéticos, en el período fonetizante, entre 5 y 6 años, que frecuentaban la última etapa de la educación infantil, en unidades escolares públicas de la región central de São Paulo. Organizamos a los niños en tres grupos de 16 integrantes, según el nivel de escritura que presentaban (silábico sin valor sonoro convencional, con valor sonoro convencional y silábico-alfabético). En entrevistas individuales realizaron tres tareas: identificación de letras fuera de contexto, escritura de palabras y completar la escritura de palabras carentes de letras iniciales.

Los resultados indican que el efecto de la motivación fonológica ligado al nombre de la letra difiere entre las diferentes tareas, o sea, puede influenciar positivamente en algunas y negativamente en otras, variando según el nivel conceptual de cada niño. Realizamos un análisis multivariado para determinar sí identificar letras influía sobre la tarea de escritura y completar palabras; la influencia del nivel conceptual para identificar, escribir y completar palabras; y, la influencia de la motivación fonológica en rendimiento infantil. Se mostró que las posibilidades del niño para utilizar e integrar información para escribir y completar palabras, no dependen del conocimiento del nombre de la letra.

Palabras clave: motivación fonológica de las letras; identificación de las letras; nível de escritura. 


\section{Summary}

Cognitive researches indicates that knowing the letters` names is crucial for learning to read and to write, as a prerequisite in the literacy process. However, according to researches of a psychogenetic nature, the possibility of using this information is conditional to the way the child understands the functioning of the writing system. In this context, this works objective was to investigate the relationship between identifying the letters names and their pertinently use in contexts of writing and completing words, taking into consideration the influence exerted by the phonological motivation of the letters. We selected 48 pre-alphabetic children, in the phonetic period, between 5 and 6 years, who attended the last stage of early childhood education in public school units in the central region of São Paulo. We organized three groups of 16 children, according to the written level (syllabic with no conventional sound value, with conventional sound and syllabic-alphabetic sound). In individual interviews, they performed three tasks: identifying letters out of context, writing words and completing words devoid of the initial letter. The results indicate that the effect of phonological motivation related to the name of the letter differs between different tasks, that is, it can influence positively in some and negatively in others, also varying according to the conceptual level of each child. We performed multivariate analysis to determine if identifying letters influences the task of writing and completing words; the influence of the conceptual level to identify, write and complete words; and the influence of phonological motivation on child performance. The results shows that the child's possibilities to use and integrate information to write and complete words do not depend on knowing the name of the letter.

Key words: phonological motivation of the letters; identifying the letters names; written level. 


\section{Sumário}

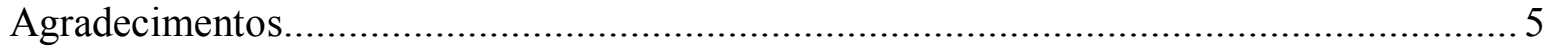

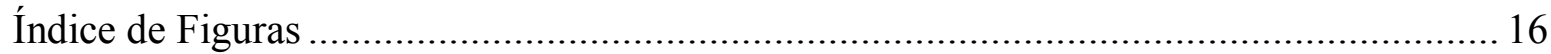

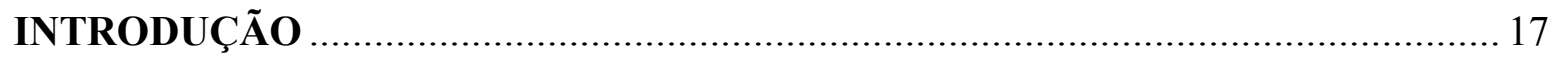

CAPÍTULO 1. REVISÃO DE LITERATURA ......................................................... 21

1.1 Pressupostos gerais da psicologia cognitiva e o que é considerado como pré-requisitos

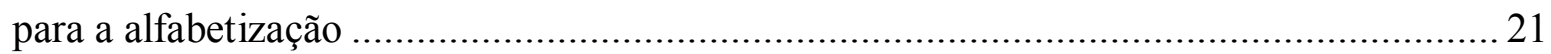

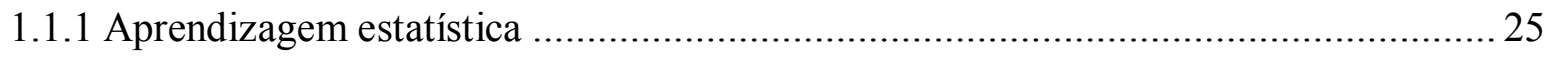

Conhecimento do nome da letra na perspectiva cognitivista....................................... 28

1.2 Pressupostos gerais da psicologia genética e o que consideram pré-requisitos para a

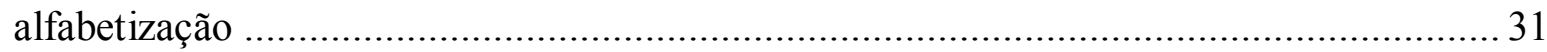

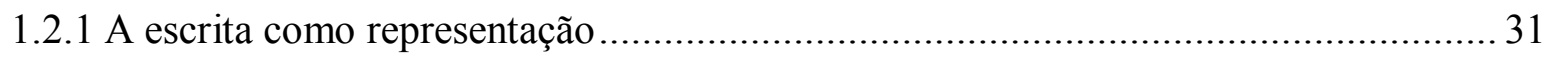

1.2.2 A construção do conhecimento e o sujeito de aprendizagem.................................. 33

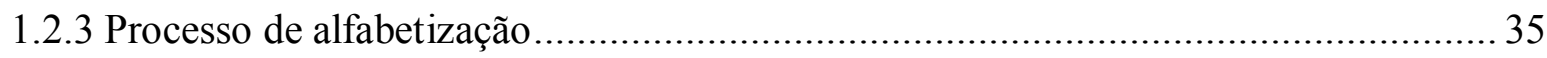

1.2.4 "Pré-requisitos" para aprendizagem da escrita em uma perspectiva psicogenética .... 38

Conhecimento do nome da letra na perspectiva da pesquisa psicogenética ...................... 41

1.3 Trabalhos sobre a aquisição da leitura e escrita em português-brasileiro...................... 44

1.4 Características fonológicas do português-brasileiro .......................................... 48

CAPÍTULO 2. PROBLEMA DE INVESTIGAÇÃO E O DESENHO

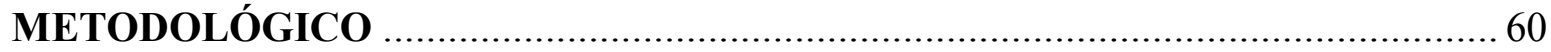

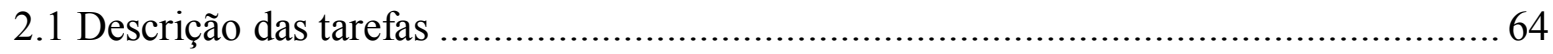

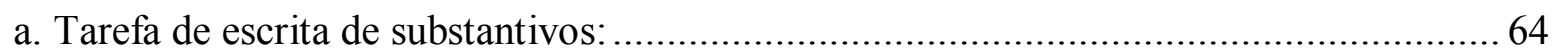

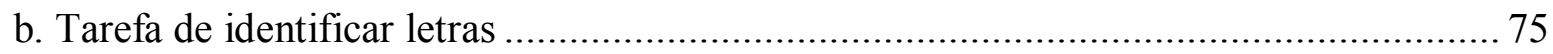

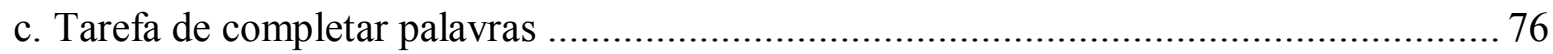

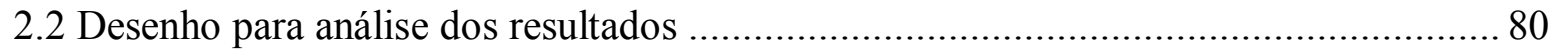

2.3 Amostra: critérios para seleção e descrição geral dos participantes............................. 80

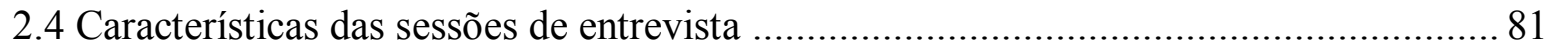

CAPÍTULO 3. ANÁLISE E DISCUSSÃO DOS RESULTADOS ............................. 82

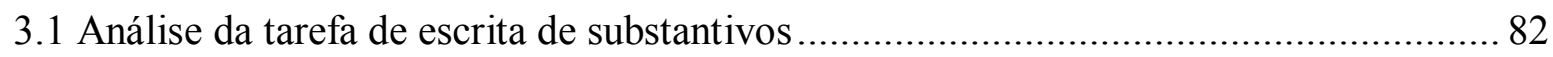

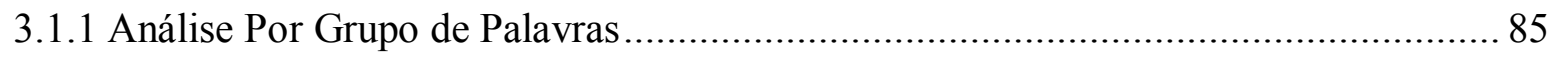

3.1.2 Escrita de sílabas com motivação fonológica versus sílabas de contraste em posição inicial.

3.1.3 Escrita de "sílabas de contraste" versus "sílabas sem motivação fonológica" em posição inicial 
3.1.4 Análise Por Nível de Escrita 93

3.1.4.1 Análise por nível de escrita, segundo a motivação fonológica da $1^{\mathrm{a}}$ sílaba 94

3.1.6 Respostas Segundo a Posição Silábica 101

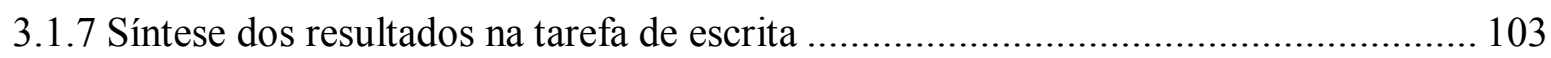

3.2 Análise da tarefa de identificação de letras fora do contexto..................................... 104

3.2.1 Análise segundo motivação fonológica da letra................................................. 110

3.2.2 Análise Por Nível de Escrita ................................................................................ 111

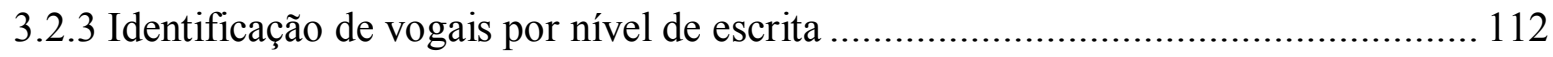

3.2.4 Identificação de consoantes por nível de escrita ............................................... 113

3.2.5 Síntese dos resultados da tarefa de identificação de letras................................... 115

3.3 Análise da tarefa de completar palavras .............................................................. 115

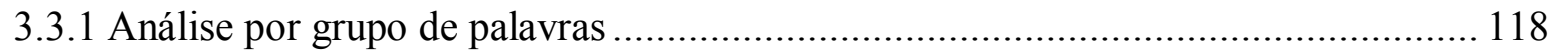

3.3.2 Completar sílabas com motivação fonológica em posição inicial........................... 120

3.3.3 Completar sílabas de contraste em posição inicial ............................................. 121

3.3.4 Completar sílabas não motivadas em posição inicial ........................................... 122

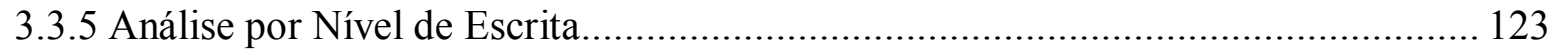

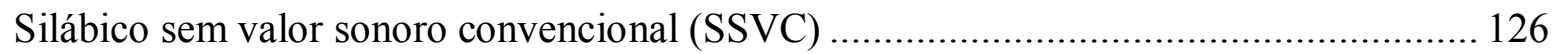

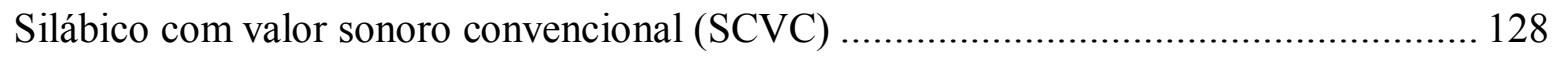

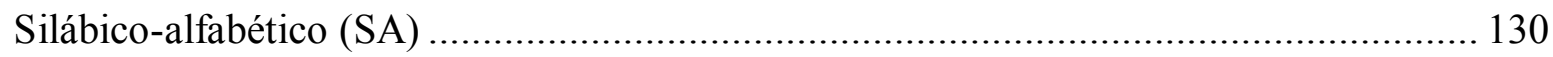

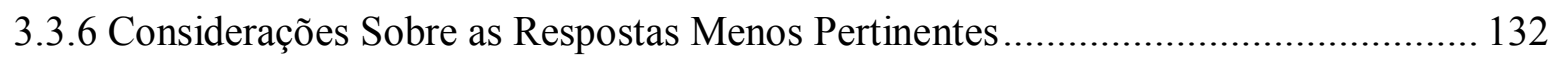

3.3.7 Síntese dos resultados da tarefa de completar palavras ...................................... 134

3.4. Análise das respostas na tarefa de escrever e completar palavras segundo a possibilidade de identificar pertinentemente as letras fora de contexto .......................... 135

3.4.1 Análise das respostas na tarefa de escrever e completar palavras das crianças que

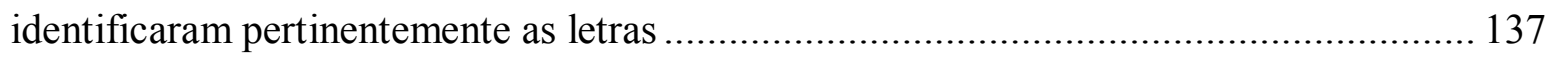

3.4.2 Análise das respostas na tarefa de escrever e completar palavras das crianças que não

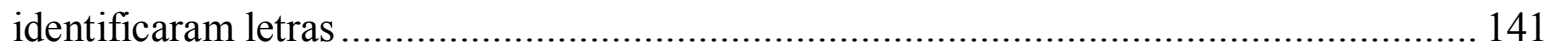

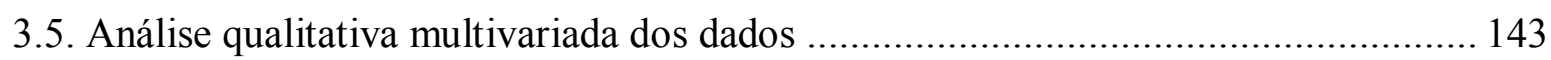

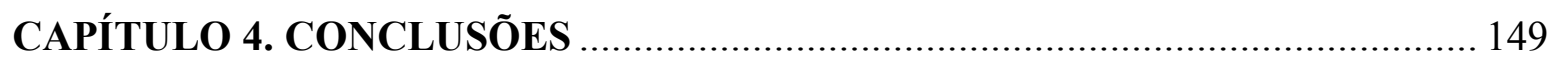

4.1 Conclusões a partir das hipóteses do estudo ....................................................... 150

4.2 Resultados contrastantes com a perspectiva cognitivista..................................... 156

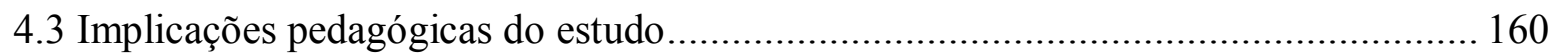

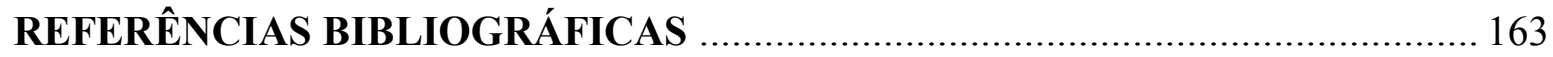




\section{Índice de Tabelas}

Tabela 1: Relação de letras do português-brasileiro e as respectivas realizações sonoras (fonemas).

Tabela 2: Relação dos fonemas do português-brasileiro que possuem mais de uma possibilidade de realizações gráficas (letras)

Tabela 3: Grau de transparência de cada idioma analisado por Seymour, P. H. K.; Aro , M;

Erskine, J. M., 2003

Tabela 4: Classificação hipotética das línguas participantes em relação às dimensões de complexidade silábica (simples, complexa) e profundidade ortográfica (superficial a profunda)

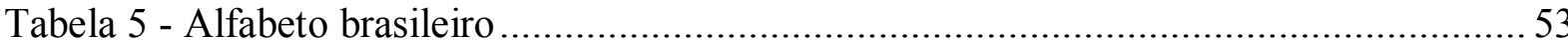

Tabela 6: Relação de vogais orais e nasais nas diferentes posições ...................................... 54

Tabela 7: Exemplo de pronúncias para a vogal E, de acordo com a variação dialetal do

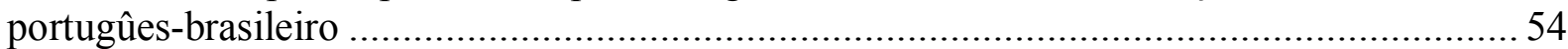

Tabela 8: Exemplo de pronúncias para as vogais postônicas mediais $[\varepsilon$, o] ......................... 55

Tabela 9: Realizações do r ou rr ortográfico possíveis em três regiões brasileiras ..................56

Tabela 10: Realizações do S possíveis em três regiões brasileiras ...................................... 56

Tabela 11: Nomes das letras do português-brasileiro, a realização oficial e outras possibilidades

Tabela 12: Valores considerados das variáveis dependentes para a hipótese 1: o nível de conceitualização da escrita determina as possibilidades de identificar letras, escrever e completar palavras

Tabela 13: Valores considerados da variável independente para a hipótese 2: conhecer os nomes das letras pode facilitar a utilização pertinente da mesma no contexto de escrita.

Tabela 14: Porcentagem de ocorrência de uso das letras no português-brasileiro, de acordo com sua motivação fonológica

Tabela 15: Categorias de palavras, de acordo com a motivação fonológica da primeira sílaba

Tabela 16: Categorias de palavras, de acordo com a motivação fonológica da primeira sílaba.

Tabela 17: Relação das palavras e opções de letras, na ordem em que foram apresentadas. .. 80 Tabela 18: Porcentagem de respostas para cada palavra segundo categorias de análise $(n=48)$

Tabela 19: Descrição das categorias que compõem os agrupamentos mais e menos pertinentes

Tabela 20: Porcentagem de respostas pertinentes e não pertinentes para cada palavra $(n=576)$

Tabela 21: Frequência e Porcentagem de cada tipo de resposta pertinente $(n=411) \ldots \ldots \ldots \ldots . . . .85$

Tabela 22: Frequência e porcentagem de respostas pertinentes e não pertinentes para cada

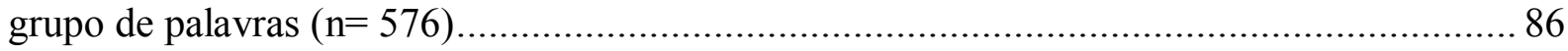

Tabela 23: Frequência e porcentagem de respostas pertinentes da tarefa de escrita, por tipo de

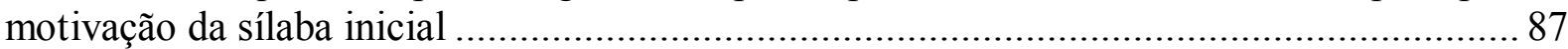

Tabela 24: Porcentagem e Frequência de sílabas motivadas na tarefa de escrita por palavra

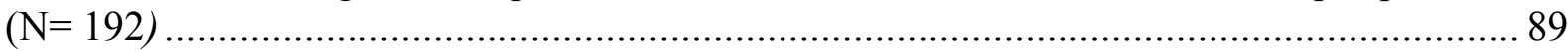

Tabela 25: Porcentagem e Frequência de sílabas de contraste na tarefa de escrita por palavra $(\mathrm{N}=192)$

Tabela 26: Porcentagem e Frequência de sílabas não motivadas na tarefa de escrita por palavra $(\mathrm{N}=192)$ 
Tabela 27: Porcentagem e Frequência de respostas na tarefa de escrita por grupo de sílabas $(\mathrm{N}=192)$

Tabela 28: Frequência e porcentagem de respostas "pertinentes" e "não pertinentes" por nível

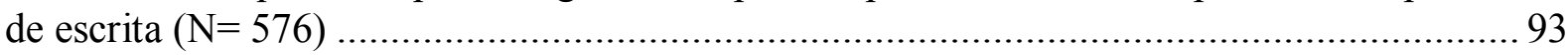

Tabela 29: Frequência e porcentagens de respostas pertinentes por nível de escrita e tipo de

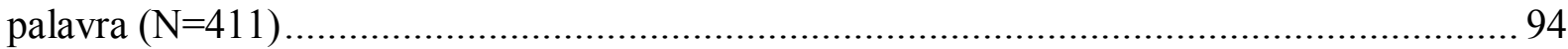

Tabela 30: Testes de qui-quadrado para a representação pertinente da sílaba inicial ............95 Tabela 31: Frequência de respostas para a representação de sílabas iniciais por tipo de sílaba e

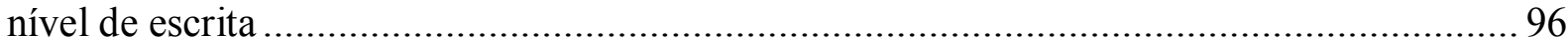

Tabela 32: Correlação de Rô Sperman entre o nível de escrita e o total de escritas convencionais $(\mathrm{CV})$ em cada grupo de palavras $(\mathrm{n}=48)$

Tabela 33: Comparação de médias (ANOVA) entre o uso de vogais nos grupos de palavras 98 Tabela 34: Correlação de Rô Sperman entre o nível de escrita e o total de utilização de vogais em cada grupo de palavras $(n=48)$

Tabela 35: Correlação de Rô Sperman entre o nível de escrita e o total de utilização de consoantes em cada grupo de palavras $(n=48)$

Tabela 36: Frequência e porcentagem de respostas por posição silábica e nível de escrita .. 101 Tabela 37: Categorias de análise para as respostas encontradas na tarefa de identificação de

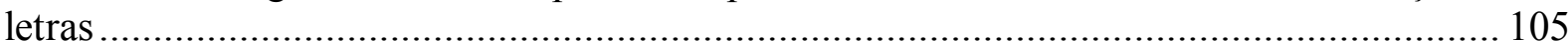

Tabela 38: Frequência e porcentagem de acordo com as categorias de respostas em geral .. 106 Tabela 39: Frequências e porcentagens de respostas pertinentes e não pertinentes .............. 106 Tabela 40: Frequências e Porcentagens de respostas de vogais pertinentes e não pertinentes

Tabela 41: Frequências e porcentagens de respostas de consoantes pertinentes e não

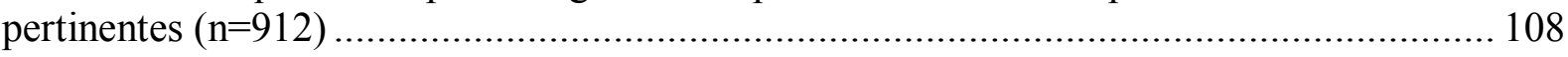

Tabela 42: Agrupamentos de consoantes segundo motivação fonológica ........................... 110

Tabela 43: Frequência e porcentagem de consoantes identificadas segundo a motivação fonológica $(\mathrm{n}=768)$

Tabela 44: Frequências e porcentagens de respostas pertinentes na tarefa de identificação de letras fora do contexto, por nível de escrita.

Tabela 45: Correlação de Rô de Spearman entre Identificação de vogais e consoantes e o nível de escrita

Tabela 46: Resumo dos Testes de Chi-Quadrada de acordo com a vogal

Tabela 47: Frequência e porcentagem de respostas corretas por tipo de consoante (motivada e

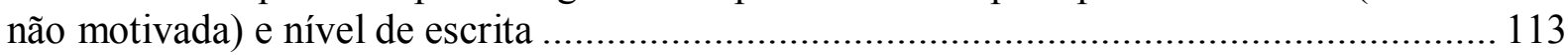
Tabela 48: Resumo dos Testes de Qui-Quadrada de acordo com a consonante motivada ... 114 Tabela 49: Resumo dos resultados dos testes de Qui-Quadrado para respostas corretas de cada consoante não motivada

Tabela 50: Frequência e Porcentagem de respostas obtidas por palavra

Tabela 51: Descrição das categorias que compõem os agrupamentos mais e menos pertinentes

Tabela 52: Frequência e porcentagem de respostas da tarefa de completar palavras, por tipo de motivação da sílaba inicial $(\mathrm{N}=576)$

Tabela 53: Porcentagem e Frequência de sílabas motivadas na tarefa de completar palavras $(\mathrm{N}=192)$

Tabela 54: Porcentagem e Frequência de sílabas de contraste na tarefa de completar palavras

$(\mathrm{N}=192)$

Tabela 55: Porcentagem e Frequência de sílabas não motivadas na tarefa de completar palavras $(\mathrm{N}=192)$ 
Tabela 56: Frequência e porcentagens de respostas pertinentes por nível de escrita e tipo de palavra $(\mathrm{N}=312)$

Tabela 57: Teste de Qui-quadrado entre nível de escrita e o total dos resultados de completar palavras motivadas.

Tabela 58: Teste de Qui-quadrado entre nível de escrita e total dos resultados de completar palavras de contraste.

Tabela 59: Teste de Qui-quadrado entre nível de escrita e total dos resultados de completar palavras não motivadas

Tabela 60: Frequência e porcentagens de respostas do grupo SSV por tipo de palavra e categorias de análise $(\mathrm{n}=192)$....

Tabela 61: Distribuição das frequências e porcentagens de respostas por palavra de contraste, no grupo de crianças SSV

Tabela 62: Frequência e porcentagens de respostas do grupo SCV por tipo de palavra e categorias de análise $(\mathrm{n}=192)$

Tabela 63: Frequência e porcentagens de respostas do grupo SA por tipo de palavra e categorias de análise $(\mathrm{n}=192)$

Tabela 64: Correlação de Rô Spearman entre nível de escrita e o total de palavras

completadas, por grupo segundo a motivação.

Tabela 65: Frequência e porcentagem de respostas por categoria, grupo de palavras e nível de escrita

Tabela 66: Correlação de Pearson Identifica letras motivadas x escreve letras motivadas x escreve letras de contraste

Tabela 67: Correlação de Pearson Identifica letras não motivadas x escreve letras não motivadas.

Tabela 68: Correlação de Pearson identifica letras motivadas x completa sílabas motivadas e de contraste.

Tabela 69: Correlação de Pearson identifica letras não motivadas x completa sílabas não motivadas.

Tabela 70: Frequências e Porcentagens de respostas nas tarefas de escrever e completar palavras motivadas, das crianças que identificaram as letras motivadas.

Tabela 71: Frequências e Porcentagens de respostas nas tarefas de escrever e completar palavras de contraste, das crianças que identificaram as letras motivadas

Tabela 72: Frequências e Porcentagens de respostas nas tarefas de escrever e completar palavras de contraste, das crianças que identificaram letras não motivadas

Tabela 73: Frequências e Porcentagens de respostas nas tarefas de escrever e completar palavras motivadas, de contraste e não motivadas, das crianças que não identificaram letras

Tabela 74: Classificação segundo os tipos de respostas

Tabela 75. Frequência de respostas coordenadas, por nível de escrita

Tabela 76: Pontuação atribuída segundo os tipos de respostas ............................................ 146

Tabela 77: Pontuação total e N por participantes, por nível de escrita ............................... 147

Tabela 78: Pontuação segundo nível de escrita e intervalo numérico ................................. 147 


\section{Índice de Figuras}

Figura 1 Exemplo de escrita silábica sem valor convencional ......................................... 66

Figura 2 Quadro que apresenta cada sílaba das referidas palavras em uma célula e as letras utilizadas para a escrita de cada sílaba.

Figura 3 Quadro que apresenta cada sílaba das referidas palavras em uma célula e as letras

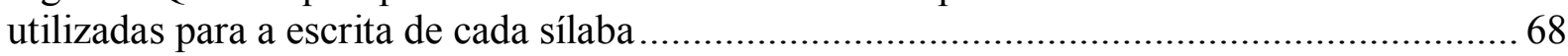

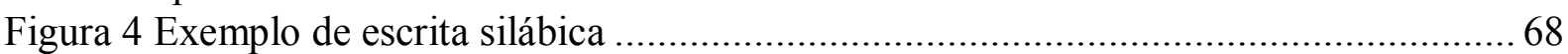

Figura 5 Quadro que apresenta cada sílaba das referidas palavras em uma célula e as letras

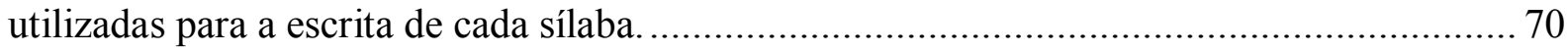

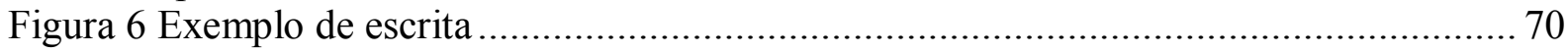

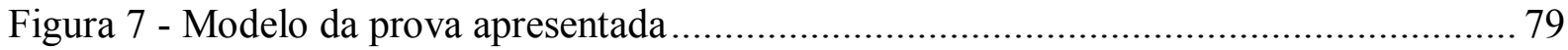

Figura 8 Distribuição das respostas pertinentes pela motivação fonológica da sílaba ........... 88

Figura 9 Porcentagens de vogais identificadas e sua ocorrência no português ..................... 108

Figura 10 Porcentagens de consoantes identificadas e sua ocorrência no português ............ 109

Figura 11 Frequência de respostas pertinentes e não pertinentes por grupo de palavras $(n=576)$

120

Figura 12 Desempenho das crianças SSV em cada grupo de palavras. .............................. 128

Figura 13 Desempenho das crianças SCV em cada grupo de palavras. ............................. 129

Figura 14 Desempenho das crianças SA em cada grupo de palavras. ................................. 130 


\section{INTRODUÇÃO}

Los niños -todos los niños, se los asseguro- están dispuestos a la aventura del aprendizaje inteligente. Están hartos de ser tratados como infradotados o como adultos em miniatura. Son lo que son y tienen derecho a ser lo que son: seres cambiantes por naturaliza, porque aprender y cambiar es su modo de ser en el mundo ${ }^{1}$

Ferreiro, 2008. p.39

A motivação por este tema de pesquisa começou a ser esboçada muito tempo antes de sua formulação objetiva. Apesar de ser um tema teórico de corte psicogenético, ele surgiu da atuação reflexiva em sala de aula no início da minha jornada profissional, quando atuava na Educação Infantil.

Naquele momento, parte do conteúdo da área de "Linguagem Oral e Escrita" desse segmento consistia no ensino do alfabeto, mais especificamente, do nome das letras. Como estava em início de carreira, desenvolvia propostas com esse objetivo, mas não conseguia encontrar sentido e tampouco contextos significativos para dedicar o precioso tempo didático de crianças tão pequenas (salas de 4 e 5 anos) para a memorização das letras. O melhor que pude fazer, naquele momento, ao invés de trabalhar a memorização, foi, por meio de brincadeiras cantadas e de cordas, ensinar a cantilena e a récita do alfabeto. Assim, quando a criança precisasse saber a grafia ou o nome de uma letra, teria uma estratégia para pesquisa dessa informação - consultando a abecedário da sala.

Algum tempo depois mudei de escola e definitivamente essa questão não voltou mais a me incomodar, pois no novo projeto didático em que eu estava trabalhando o objeto de ensino não era a língua em si, mas a prática social de uso da linguagem, ou seja, a aprendizagem por meio do uso, da atuação da criança enquanto leitora e escritora, mediante suas possibilidades em cada momento. Por isso, as intervenções didáticas visavam, sobretudo na Educação Infantil e séries iniciais, não o ensino de conteúdos que supostamente seriam pré-requisitos para a alfabetização, mas sim a formulação de propostas pedagógicas que proporcionassem contextos escolares em que a linguagem é "consumida" e produzida da forma mais semelhante possível à feita fora da escola. Portanto, o ensino descontextualizado da letra (entre outros elementos) não ocorria sequer no $1^{\circ}$ ou $2^{\circ}$ Ano do Ensino Fundamental 1.

\footnotetext{
1 Tradução livre da autora: As crianças -todas as crianças, posso assegurar- estão dispostas à aventura da aprendizagem inteligente. Estão fartas de serem tratadas como pouco dotadas ou como miniatura de adultos. São o que são e têm o direito de ser o que são: seres mutantes por natureza, ou seja, que estão em constante mudança, porque aprender e mudar é seu modo de ser no mundo.
} 
Esta reflexão somente retornava quando escutava professores de outras escolas em simpósios e congressos, em cursos de formação ou quando atuava como professora particular para alunos de importantes colégios privados da cidade de São Paulo. Nesta situação específica, comecei a formular a hipótese de que, para algumas crianças, saber somente o nome da letra não só não ajudava, mas também atrapalhava a aprendizagem da leitura e da escrita. Algumas crianças ficavam presas a essa informação e não se arriscavam em outras estratégias possíveis para ler ou escrever, não aproveitavam outras pistas textuais e contextuais e limitavam-se à decodificação. Algumas recorriam à transcrição fonética, tentando segmentar o máximo possível as palavras e associá-las a uma letra, contudo, saber que a letra J se chama (JOTA) não ajuda quando a criança precisa evocar qual letra representa o [3] em [jangada] - ainda que consiga fazer essa segmentação fonética. No contexto da leitura não era diferente: ao se deparar com a palavra [jangada], pensar que a primeira letra é o "jota" não a ajudará a pensar no que a palavra poderá representar. Pior, algumas crianças, ao se depararem com o desafio de ler, prendiam-se à única possibilidade de que dispunham e apenas soletravam as palavras escritas.

Nesse momento, já estava terminando a pós-graduação lato sensu em alfabetização no Centro de Estudos da Escola da Vila, em São Paulo, e ingressando neste programa de mestrado em "Escritura y Alfabetización", na Universidad Nacional de La Plata, onde pude me aprofundar nas questões apresentadas nesta pesquisa.

Por essa razão, o presente trabalho tem por objetivo investigar a relação entre identificar as letras por seus respectivos nomes e a possibilidade de utilizá-las de maneira pertinente em contextos de escrita e de completar palavras. Também foi objetivo do trabalho verificar se a coincidência sonora entre o nome da letra e o segmento silábico correspondente, ou seja, se a motivação fonológica da sílaba é uma característica fonológica útil em qualquer contexto de utilização e em qualquer nível conceitual de escrita.

Como dito no início desta introdução, há diferentes formas de conceber o processo de alfabetização e delas decorrem diferentes sentidos e importâncias às informações que as crianças recebem sobre o sistema de escrita, sobretudo em relação à relevância do conhecimento do nome da letra e à consciência grafema-fonema.

No modelo cognitivista, por exemplo, pressupõe-se que o conhecimento do nome da letra garanta a possibilidade de a criança interpretar a escrita, ou seja, é pré-requisito para a alfabetização. Já na perspectiva psicogenética, os esquemas de assimilação (Emília Ferreiro, 1997, 2009; Emília Ferreiro e Teberosky, 1999; Piaget, 1967, 1971, 1972, 1973, 1977, 1978) condicionam as crenças infantis sobre o funcionamento do sistema de escrita e mediam a 
compreensão que as crianças têm a respeito do que representa a escrita de forma global e cada um de seus componentes gráficos.

No entanto, a maioria dos estudos realizados sobre a influência do conhecimento do nome da letra no processo de alfabetização, além de partir de uma perspectiva cognitivista, foi produzida em Língua Inglesa, com crianças norte-americanas (Ehri, 1998; Pollo, Treiman, e Kessler, 2008; Treiman e Bowman, 2002, 2008; Treiman e Rodríguez, 1999; Treiman, Weatherstone e Berch, 1994). Contudo, a Língua Portuguesa tem características morfológicas, fonológicas e ortográficas muito distintas das características do Inglês, o que torna difícil a aplicação simples e direta para o Português das conclusões de tais estudos; e, por isso, a necessidade de realizar pesquisas neste idioma que considerem as particularidades de sua estrutura e organização.

Além de ser produzido em Língua Portuguesa e desenvolvido com crianças falantes nativas do português-brasileiro, esse trabalho parte de uma perspectiva psicogenética, na qual os sujeitos constroem, por meio de uma ação inteligente, representações sobre o funcionamento do sistema de escrita, e, à medida que as confrontam com as limitações oferecidas pelo meio, se veem diante da necessidade de reformular essas representações, criando novas hipóteses que progressivamente se aproximam e se ajustam à convencionalidade do sistema.

Partindo dessa postura, propomos um desenho metodológico que permite relacionar as conceitualizações infantis sobre a escrita com a informação que a criança tem sobre os nomes das letras identificadas fora de contexto e a possibilidade de escrever e completar o segmento inicial de palavras.

Com este desenho experimental, discutiremos cada variável isoladamente e articuladas umas com as outras para conhecer a relação entre o conhecimento do nome das letras e a possibilidade de utilizá-lo para escrever e completar palavras.

As formas de se conceber a alfabetização e o ensino e aprendizagem da língua são fortemente atravessadas pelas concepções que se tem do objeto - no caso, a língua ou as práticas de linguagem - e dos sujeitos envolvidos. O primeiro capítulo deste trabalho destina-se à discussão dessas concepções, uma relacionada à perspectiva cognitivista e outra à perspectiva da psicologia genética, destacando em ambas as posturas as ideias que defendem acerca da importância do conhecimento do nome da letra. Como este estudo é desenvolvido com crianças falantes do português-brasileiro, incluímos uma parte para descrever as características do sistema fono-ortográfico do português. 
No capítulo 2 discutimos o planejamento que estrutura a pesquisa, apresentando os objetivos, as hipóteses, a justificativa, a seleção da mostra, bem como o desenho metodológico realizado. Aqui aparecem o detalhamento das tarefas realizadas e as variáveis consideradas na análise.

No capítulo 3 apresentamos os resultados obtidos em cada uma das tarefas, a análise e a discussão das variáveis envolvidas em nosso problema de investigação.

Por fim, no capítulo 4, traçamos as conclusões possíveis a partir dos dados e das análises realizadas, e as implicações pedagógicas em relação ao papel do ensino do nome da letra no início da escolaridade. 


\section{CAPÍTULO 1. REVISÃO DE LITERATURA}

Como as formas de se conceber a alfabetização inicial são fortemente atravessadas pelas concepções que se tem do objeto, no caso, a língua ou as práticas de linguagem, e dos sujeitos envolvidos, neste primeiro capítulo apresentaremos mais detalhadamente os fundamentos das perspectivas cognitivista e psicogenética.

Devido ao fato deste estudo ter sido realizado com crianças falantes do portuguêsbrasileiro, incluímos um item para destacar estudos anteriores realizados em português e para descrever as características do sistema fono-gráfico desse idioma.

\subsection{Pressupostos gerais da psicologia cognitiva e o que é considerado como pré-requisitos para a alfabetização}

A perspectiva da psicologia cognitiva é a mais aceita e difundida na comunidade educativa, especialmente por duas razões: 1) porque a explicação coincide com o "sentido comum" daquele que aprendeu a ler e a escrever e que não sabe como aprendeu, ou seja, porque segue a lógica do adulto já alfabetizado, que não se lembra do processo pelo qual passou; 2) porque teoricamente obedece a um modelo meramente "objetivo", que não propicia conjecturas sobre o sujeito que aprende.

$\mathrm{Na}$ perspectiva cognitivista, a língua escrita é vista como um código que transcreve a linguagem oral de forma direta, clara e linear. Ou seja, a escrita é entendida como um sistema de signos que expressam os sons da fala e que têm relação biunívoca entre as unidades sonoras (fonemas) e as unidades gráficas (as letras).

Ao se conceber a escrita como um código no qual cada grafema corresponde a um fonema, torna-se imprescindível o estabelecimento correto da respectiva associação para que a criança aprenda a escrever. E, para que isto ocorra, é preciso que ela consiga, inicialmente, perceber cada fonema que compõe a palavra que pronuncia.

Por essa razão, os teóricos identificados com essa linha apontam como fundamentais os exercícios de análise das emissões orais, como, por exemplo, observar e comparar a duração acústica de palavras, identificar a quantidade de sílabas que tem um enunciado, ou as menores partes de uma palavra etc. Esses exercícios, segundo Delfior (2008); Goswami, Gombert, e De Barrera (1998); Signorini (1988), favorecem que as crianças, progressivamente, tornem-se conscientes das unidades nas quais a fala se divide (consciência fonológica): desde as palavras que compõem as frases até as unidades menores, os fonemas. Esses treinos permitiriam uma 
análise da fala e, ao compreender-se como esta se organiza e a sua natureza segmental, descobrir-se-ia o seu correlativo gráfico.

Dentro dessa mesma teoria, estudiosos debatem se a capacidade de ser consciente das unidades nas quais a fala pode se dividir precede (no sentido de facilitar, de ser uma condição, um pré-requisito) a aquisição da linguagem escrita, se é posterior (somente após aprender o sistema alfabético é que se desenvolve a consciência fonêmica), ou, ainda, se as relações são de reciprocidade: a aprendizagem da escrita favorece o desenvolvimento da consciência dessas unidades menores, bem como pensar sobre as unidades menores ajuda os avanços na escrita. Signorini (1988, p. 3) sintetiza a questão:

Desde el punto de vista teórico puede argumentarse que la habilidad para analizar la estructura fonológica de las palabras habladas facilitará al niño el descubrimiento del principio alfabético. El argumento contrario es que el contacto con la escritura alfabética provee conocimientos explícitos acerca de la estructura fonológica del lenguaje oral, que complementa el conocimiento implícito implicado en los procesos de producción y percepción del habla. Una tercera posibilidad es que la conciencia fonológica y la lectura y la escritura se desarrollen en forma recíproca. ${ }^{2}$

Castedo e Torres (2012), pesquisadoras de alinhamento psicogenético, escrevem em um artigo que resgata o panorama histórico da alfabetização que, apesar dessas divergências internas, o paradigma atual mais aceito na América Latina e nos Estados Unidos é o de que o desenvolvimento da consciência fonológica precede e guia a aprendizagem da leitura. Segundo Borzone e Signorini (1988), representantes da teoria cognitivista, “(...) uma vez que as crianças compreendem a natureza da fala - sua estrutura segmental -, descobrem com mais facilidade de que maneira a escrita representa a linguagem” (Borzone e Signorini, 1988, p. 7).

Portanto, ao conquistar essa habilidade, as crianças podem inferir as correspondências letrasom.

A postura cognitivista também está fortemente influenciada pela forma de se conceber o sujeito da aprendizagem: passivo e não atuante com o objeto de conhecimento; a aprendizagem, por sua vez, é o resultado direto do ensino, entendido como transmissão do saber daquele que sabe para aquele que não sabe, e do treinamento de um conjunto de habilidades (Goswami e Ziegler, 2005).

\footnotetext{
${ }^{2}$ Tradução da autora: A partir desse ponto de vista teórico pode argumentar que a habilidade para analisar a estrutura fonológica das palavras faladas facilitará a descoberta do princípio alfabético por parte da criança. $\mathrm{O}$ argumento contrário é que o contato com a escrita alfabética provê conhecimentos explícitos sobre a estrutura fonológica da linguagem oral, que complementa o conhecimento implícito implicado nos processos de produção e percepção da fala. Uma terceira possibilidade é de que a consciência fonológica e a leitura e a escrita se desenvolvam de forma recíproca.
} 
Essa perspectiva parte da ideia de que todo esforço cognitivo para ler e escrever é centrado na análise da oralidade, pois, ainda que se recorra a materiais escritos, o objetivo é que este forneça informações sobre como a linguagem oral se organiza. Entretanto, a consideração de que a linguagem escrita provê conhecimentos explícitos acerca da estrutura fonológica da linguagem oral (Signorini, 1988) foi um dos fatores que motivou o desenvolvimento da pesquisa psicogenética. Nela se contesta o status da língua escrita como o resultante de uma série de habilidades (motoras, de codificação, de consciência fonológica etc.), cuja estrutura, para ser ensinada, precisa ser retirada de seu contexto de uso e fragmentada em unidades menores.

Mais recentemente, estudiosos cognitivistas têm se dedicado a analisar as características dos sistemas de escrita em relação à maior ou menor opacidade ortográfica, bem como às características fonológicas e fonéticas de diversos idiomas (Delfior, 2008; Goswami et al., 1998; Treiman, 1998, 2004; Treiman e Bowman, 2002, 2008; Treiman, Pollo, Cardoso-Martins, e Kessler, 2013).

Segundo Frost, Katz, e Bentin (1987), as línguas que possuem um código alfabético são classificadas em função do grau de consistência entre os fonemas e as letras que os representam, ou seja, se são opacas ou transparentes.

Estes termos, oriundos da Pragmática, são utilizados para se referir à relação entre significado e significante. No que diz respeito à escrita, consideram-se transparentes as grafias que correspondem somente a uma interpretação fonética possível (Leal, Matute, e Zarabozo, 2005). Portanto, quanto maior a relação grafo-fonética, maior a transparência. O inglês, por exemplo, é considerado uma língua pouco transparente, portanto, mais opaca: tem 44 fonemas, que são representados por apenas 25 letras, ou seja, poucas letras para representar uma quantidade grande de fonemas - o que faz com que uma mesma letra seja responsável por representar mais de um fonema; já o espanhol possui ligeiramente mais letras, mais representações gráficas que fonemas: 27 letras para 24 fonemas, o que o torna uma língua com alto grau de transparência, visto que a proporção letra-fonema é bastante próxima. Já o português estaria em um nível intermediário - nem tão opaco quanto o inglês, nem tão transparente quanto o espanhol: possui 34 fonemas, que são representados por 27 letras.

Segundo estudos de Goswami et al. (1998); Goswami e Ziegler (2005), a sensibilidade a determinadas características linguísticas depende da ortografia de cada idioma: quanto mais transparente uma língua, como é o caso do espanhol, mais eficiente é o treinamento grafema- 
fonema, quanto menos transparente, como o inglês, mais útil é o treino com unidades linguísticas maiores, como as rimas.

Liberman, Shankweiler, Fischer e Carter (1974) apontam que, nesta perspectiva, o maior desafio enfrentado pelas crianças quando estão aprendendo a escrever é compreender que as letras representam os fonemas. Teóricos como Ehri (1998), Frith (1985) e Gentry (1982) propõem modelos de como ocorre a aquisição do conhecimento fonológico durante a alfabetização. Segundo estes autores, esta acontece por meio de fases, que se iniciam desde antes do entendimento da relação fonográfica do sistema alfabético e vão até o momento em que é possível reconhecer rapidamente e com precisão as palavras escritas.

Nessa perspectiva, considera-se que as crianças passam por um momento inicial "préalfabético" ou "logográfico", no qual não estabelecem relação com os sons das palavras, cujo reconhecimento ocorre a partir de pistas visuais ou contextuais (cores, tipo de letra e/ou o portador textual) e não pela observação de cada elemento gráfico que compõe a palavra. É somente a partir do momento em que aprendem os nomes das letras, que começam a entender que estas representam os sons, que passam, então, a representar alguns dos sons que identificam nas palavras com as respectivas letras. Esse momento é chamado de fase alfabética parcial (Ehri, 1998), ou estágio semifonético (Gentry, 1982)³.

A próxima etapa é chamada de fase alfabética total ou estágio fonético, momento em que a escrita corresponde totalmente à fonologia das palavras e as crianças escolhem as letras de acordo com seus respectivos sons, sem, no entanto, terem a preocupação com a convenção ortográfica. Somente quando as crianças adquirem conhecimentos sobre os padrões grafotáticos ${ }^{4}$ de sua língua é que começam a produzir escritas ortograficamente convencionais, alcançando a última etapa, o "estágio correto" ou a "fase alfabética consolidada".

Outro conflito interno dessa teoria é que, apesar de reconhecer que as crianças utilizam conhecimentos linguísticos na escrita e não apenas a memorização, ela dá pouca atenção aos aspectos não fonológicos do sistema de escrita. Isso porque, para o modelo fonológico, a aprendizagem dos padrões grafotáticos ocorre somente no estágio final do desenvolvimento da escrita.

\footnotetext{
3 Ehri (1998) e Gentry (1982), respectivamente, propõem duas teorias sobre o desenvolvimento da linguagem escrita: teoria de estágios e teoria de fases.

${ }^{4}$ Padrões grafotáticos são características que se referem somente à escrita, sem correspondência com o oral. Por exemplo, uso de letras maiúsculas e minúsculas; regularidades ortográficas, como não utilizar letras iguais seguidamente, no caso do português (que somente algumas são permitidas no meio das palavras e nunca no início ou ao final, como o RR e SS), pontuação, conceito de palavra e separabilidade, entre outras.
} 
Contudo, para Treiman (1998 e 2004) e Treiman et al. (2013), o fato de as crianças na fase pré-fonética - muitas vezes - utilizarem letras quando escrevem sugere que elas já possuam conhecimentos sobre a escrita, que refletem características do sistema ao qual foram expostas, mostrando sensibilidade aos padrões gráficos de seu idioma. Por exemplo, crianças americanas nessa fase dificilmente escrevem utilizando muitas consoantes repetidas no início das palavras, pois essa representação não é observada em seus idiomas. Estas seriam evidências de que o conhecimento não fonológico é importante desde o início do desenvolvimento da linguagem escrita.

Para dar conta dessa lacuna encontrada nas teorias fonológicas, a perspectiva da aprendizagem estatística - que deriva da postura cognitivista, pois partem das mesmas premissas e dos mesmos princípios - se propõe a buscar respostas.

\subsubsection{Aprendizagem estatística}

Como visto anteriormente, o modelo da consciência fonológica apresenta dois limites principais: 1. Partindo de trabalhos com usuários de sistemas de escrita não alfabéticos, Bryant e Bradley (1987), entre outros autores, mostram que a consciência fonológica é resultado do processo de alfabetização (em um sistema alfabético de representação), de maneira que aqueles que ignoram este tipo de representação (a população analfabeta ou alfabetizada em sistemas não alfabéticos) não têm a consciência fonológica no nível do fonema, o que os levou a concluir que os fonemas não são uma unidade natural ou pré-existente psicologicamente; 2. A falta de atenção à ortografia das línguas escritas, pois, como apresentado por Goswami et al. (1998), não é equivalente aprender a ler e a escrever em línguas mais ou menos transparentes. Mesmo em sujeitos que possuem a consciência fonológica totalmente desenvolvida, sistemas ortográficos menos transparentes (como o inglês) fazem com que o tempo de aprendizagem do respectivo sistema seja menos ágil que para aprendizes de sistemas de ortografia mais transparentes (como o espanhol). Além disso, investigadores como Read e Treiman (2013) observaram também que os aprendizes tentam escrever de maneiras próximas às convencionais no decorrer de sua aprendizagem. De tal modo que deixam de lado os estudos centrados sobre a leitura para considerar as "escritas inventadas" (inventend spellings) das crianças como um foco possível de análise que lhes permita explicar como conseguem incorporar o uso convencional das letras.

Nesse sentido, propõem a perspectiva da aprendizagem estatística e defendem que a escrita das crianças reflete as características dos dados a que estão expostas. Isso porque as 
crianças inseridas em sociedades letradas têm contato desde cedo com diversos portadores textuais, podendo, assim, observar e aprender os padrões grafotáticos de seu idioma. Desse modo, aprendem, por exemplo, sobre as restrições relacionadas à ordem e à organização das letras (Pollo, Treiman, e Kessler, 2015). Como as escritas iniciais já refletem as características da língua, é esperado que as produções sejam bem distintas entre crianças de diferentes idiomas.

Essa proposta se baseia no modelo conexionista, que consiste na captação de regularidades expressas na frequência das grafias com as quais a criança tem contato. Por essa razão, justifica-se a utilização por crianças pré-alfabéticas das letras dos seus nomes na escrita de palavras diversas, já que esta é uma grafia de presença frequente e regular. Contudo, acreditase que incrementar a quantidade de palavras às quais a criança está exposta diminuirá esse efeito do nome próprio, fazendo-a utilizar padrões mais gerais do sistema de escrita (Pollo et al., 2015; Treiman, Sotak, e Bowman, 2001).

Outra investigação realizada por esse grupo de pesquisadores do modelo da aprendizagem estatística foi um estudo de análise e comparação entre a aquisição da escrita em português (brasileiro) e o inglês, com o objetivo de observar aquilo que é comum no desenvolvimento e aquilo que, no desenvolvimento, está relacionado às características do idioma.

De acordo com Pollo, Kessler e Treiman, (2005a), as crianças de línguas romanas costumam utilizar mais vogais em suas produções que consoantes, porque nesses idiomas há maior ocorrência de vogais, enquanto crianças falantes do inglês utilizam mais consoantes, porque em inglês há maior ocorrência de consoantes.

One quantitative difference in the input is that Portuguese words have more vowels than do English words, as documented in Study 1. Given this, it should not be surprising to see more vowels in the spontaneous spellings of Portuguese speakers, as we did in Study 2. Even when the words that English and Portuguese children are asked to spell contain an identical number of vowels, as was the case in that study, the relative preponderance of vowels in Portuguese vocabulary as a whole seems to exert a small but measurable indirect influence. When young spellers are uncertain as to which letter to use, their last resort may well be to fall back on familiarity. ${ }^{5}$ (Pollo et al., 2005a, p.178,)

\footnotetext{
${ }^{5}$ Tradução de autora: Uma diferença quantitativa é que no português as palavras têm mais vogais que no inglês, como foi documentado no Estudo 1. Dado isto, não deveria ser surpreendente ver mais vogais nas grafias espontâneas dos falantes de português, como vimos no Estudo 2. Mesmo quando as crianças têm que soletrar palavras com um número idêntico de vogais, como foi pedido no estudo, a predominância relativa de vogais no vocabulário português como um todo parece exercer uma pequena mas significativa influência indireta. Quando crianças não têm certeza que letra escolher na hora de soletrar, seu último recurso pode ser o de apostar no que soa familiar.
} 
Pollo et al. (2015) observaram também que as frequências de letras e diagramas (sequência de duas letras) coincidiam em relação à frequência e ao padrão gráfico nos dois idiomas analisados. Também estavam de acordo com a estrutura linguística das línguas a quantidade mínima e a variação interna de letras comumente utilizadas pelas crianças para considerarem o conjunto de letras como uma escrita.

Em estudo anterior, C. Cardoso-Martins, Resende, e Rodrigues (2002) e Pollo, Kessler e Treiman, (2005b) já haviam observado que letras vogais, fonemas vogais e vogais motivadas fonologicamente (palavras em que o som da vogal coincide com o nome da letra) são mais comuns em português que em inglês, e esta seria a razão para a frequência do uso de vogais nas produções escritas de crianças brasileiras: como as crianças, ao entrarem em contato com material escrito, visualizam mais vogais, ao escreverem usam mais vogais que outras letras.

De acordo com esses estudos, a criança utiliza o conhecimento que tem sobre o nome da letra, escrevendo-a sempre que escuta seu nome em uma palavra. Como acreditam que as vogais são as mais facilmente identificáveis, dado sua ocorrência em português, bem como a frequência de palavras dissílabas, é natural que para cada palavra as crianças utilizem aproximadamente duas vogais.

The fact that the name of a letter can be heard in most Portuguese words may make it easier for children to gain the insight that writing is a representation of sounds. After children have gained that insight, the fact that it can be applied on average two times per word may provide additional encouragement, as may the fact that teachers and caregivers are more likely to appreciate and praise spelling attempts where a couple of letters are reasonable representations of sounds in the word. ${ }^{6}$ (Pollo et al., 2005a, p. 170).

Esta explicação justificaria porque as produções silábicas, que observamos em crianças em fase inicial de alfabetização, ocorrem: não por serem representativas de que a criança tem como hipótese que a língua se organiza em sílabas, menor unidade sonora com sentido que podem inicialmente observar, como formulam Ferreiro e Teberosky (1999), mas sim como efeito da correspondência entre o som da letra escutada (fonema) e seu respectivo nome/grafia. Essa associação estaria favorecida pela frequência com que as vogais ocorrem em textos no português, bem como por serem letras frequentemente motivadas fonologicamente. Portanto,

\footnotetext{
${ }^{6}$-Tradução de autora: $\mathrm{O}$ fato de o nome de uma letra poder ser ouvido na maior parte das palavras em português pode facilitar a compreensão de que a escrita é a representação de sons. Depois que crianças fazem essa descoberta, o fato que ela pode ser aplicada, em média, duas vezes por palavra pode prover mais encorajamento, como também a maior probabilidade de que professores e cuidadores apreciem e elogiem as tentativas de escrita quando algumas letras são representações razoáveis de seus respectivos sons.
} 
ao saber o nome da letra e escutar esse nome no momento da escrita de uma palavra, a criança faz a correspondência e simplesmente grafa a letra escutada.

Lourenço e Alves Martins (2010) partem do pressuposto de que a consciência fonológica, as escritas inventadas e o conhecimento do nome da letra são fundamentais e prérequisitos para a aquisição da leitura e da escrita. Eles investigaram um grupo de 28 crianças pré-escolares, portuguesas, com a finalidade de observar como esses aspectos se desenvolvem ao longo do ano escolar e como se relacionam entre si.

Os resultados encontrados demonstraram uma evolução significativa em cada um desses elementos ao longo do ano. No início do ano, somente as provas de consciência fonológica (classificação da sílaba e do fonema inicial) possuíam relação entre si. Na testagem realizada no meio do ano, além da relação entre as provas de consciência fonológica, observaram associação entre a consciência silábica e o número de letras que as crianças conheciam. Por fim, na última testagem, realizada no final do ano letivo, além de todas as associações estabelecidas anteriormente, observaram relação entre a escrita e o conhecimento do nome das letras. Esses resultados mostram que "quanto mais evoluídas são as escritas das crianças, mais letras elas conhecem e quanto mais letras conhecem maior é a sua consciência silábica e viceversa”(Lourenço e Alves Martins, 2010, p. 2759). Além disso, quanto maior a consciência da sílaba, maior a do fonema, já que esta associação está estabelecida desde a primeira testagem e se manteve em todas as demais.

Apesar de se tratar de um estudo correlacional, que não evidencia qual variável estaria influenciando a outra, as autoras apontam consonância com estudos anteriores (Alves-Martins e Silva, 1999; Treiman, 1998) sobre a importância do conhecimento do nome da letra para a evolução da escrita, principalmente no início da fonetização.

\section{Conhecimento do nome da letra na perspectiva cognitivista}

Dessa perspectiva, o conhecimento do nome da letra é fundamental, pois é esse saber que dispara que a criança com escrita pré-fonológica estabeleça relação entre aquilo que se escreve e a pauta sonora, já que o nome da letra contém o som que ela tipicamente representa nas palavras. Para Ehri (1986), saber os nomes das letras favorece a correspondência letra-som; isso ocorre, de acordo com essa visão, pois os nomes das letras são escutados na pronúncia das palavras. 
Segundo Cardoso-Martins et al. (2002), 51 das 56 palavras mais frequentes em livros infantis, destinados às séries iniciais, contêm ao menos uma letra cujo nome aparece na forma oral da palavra.

Pollo et al. (2005a) e Treiman e Rodríguez (1999) mostraram que letras com motivação fonológica (coincidência do nome da letra com o som/nome da sílaba) são frequentes em muitos idiomas e que esta informação favorece a criança a estabelecer relações grafo-fônicas.

A letter name spelling strategy may also contribute to the greater number of vowel letters in early Portuguese spelling than in early English spelling. Study 2 documented that children are more likely to insert a vowel letter in their spelling if they hear its letter name in a word. ${ }^{7}$ (Pollo et al., 2005a, p. 178)

Treiman e Bowman (2008) realizaram um estudo para verificar se as crianças que não leem nem escrevem convencionalmente produzem e leem de maneira logográfica ou se usam conhecimentos de natureza fonológica. Aplicaram um teste em 42 pré-escolares, falantes nativos do inglês, que consistia em tarefas de escrita e de leitura envolvendo quatro grupos de conjunto de letras. Um composto por vogal e consoante (VC) motivadas, outro por consoante e vogal (CV) motivadas, outro por vogal e consoante (VC) aleatórias, e o quarto por consoante e vogal (CV) aleatórias. Vale destacar que as letras apresentadas não formavam palavras escritas em sentido estrito, apenas sua representação silábica (uma letra para cada sílaba). No caso das letras motivadas, por exemplo, eram letras cujos nomes constituíam sílabas plausíveis, e foram apresentadas apenas as letras e não a sílaba completa. Por exemplo: para a palavra (em inglês) APE, foram apresentadas as letras AP. Já no grupo de palavras arbitrárias foram apresentadas letras sem relação de qualquer natureza com a palavra pronunciada.

A ideia é que se a leitura e a escrita fossem logográficas, os resultados apresentados para os diferentes grupos de palavras seriam equivalentes. Contudo, as crianças apresentaram melhor desempenho nas condições foneticamente motivadas do que nas condições arbitrárias. As autoras concluíram que mesmo tendo habilidades limitadas de leitura e escrita, as crianças que possuem conhecimento sobre o nome das letras não podem ser limitadas a modelos de ensino baseados na abordagem logográfica: "These findings suggest that, as young children gain

7 Tradução livre da autora: A estratégia de soletrar o nome de uma letra também pode contribuir para o número maior de vogais nas escritas juvenis do português em comparação com as escritas juvenis do inglês. O Estudo 2 documentou que as crianças são mais propensas de inserir uma vogal na sua escrita se elas ouvem seu nome em uma palavra. 
familiarity with the names and sounds of letters, their ability to benefit from alphabetically motivated links between spellings and sounds improves"8 (Treiman e Bowman, 2008, p. 167).

Apesar de o desempenho ter sido equivalente entre vogais e consoantes motivadas, as autoras observaram que a posição que o fonema ocupava na "palavra" não foi equivalente e concluíram que as letras motivadas localizadas em posição inicial se mostraram mais úteis para as crianças do que aquelas em posição final. Também observaram melhor desempenho das crianças com letras motivadas nas tarefas de escrita do que nas de leitura.

Cardoso-Martins e Batista (2005) encontraram resultados semelhantes para o português. Em seus testes, as crianças deveriam escrever pares de palavras, sendo uma iniciada por uma sílaba motivada fonologicamente (coincidência entre o som da sílaba e o nome da letra, por exemplo, TELEFONE) e seu respectivo par iniciada por sílabas sem motivação fonológica, por exemplo, TARTARUGA. Concluíram que “(...) crianças falantes do português se valem do seu conhecimento do nome das letras para conectar a escrita à fala, pelo menos quando o nome inteiro da letra pode ser detectado na pronúncia da palavra" (Cardoso-Martins e Batista, 2005, p. 334).

Em estudo anterior, Treiman e Rodríguez (1999) pesquisaram sobre a utilidade do conhecimento do nome das letras e o conhecimento do som da letra em situações de leitura e verificaram que as crianças desde muito cedo buscam estabelecer relações entre a escrita e a sua pronunciação e que algumas relações são mais fáceis de a criança observar, como o nome da letra, sobretudo quando esta está no início das palavras. "When spellings make sense on the basis of letter names - as with our invented words such as BT for "beet" and with real words such as Jane, deep, and eel-even young children can begin to grasp them"9 (Treiman e Rodríguez, 1999, p. 338).

Segundo as autoras, as crianças ativamente buscam o sentido do sistema de escrita utilizando todo o conhecimento que têm disponível. Rechaçam a ideia de que memorizam palavras impressas como se fossem símbolos arbitrários.

Em oposição a essa perspectiva, encontramos a Psicologia Genética, que veremos a seguir, e que parte de uma concepção distinta sobre o objeto de ensino e aprendizagem e sobre os sujeitos envolvidos.

\footnotetext{
8 Tradução livre da autora: Essas descobertas sugerem que, assim que crianças se familiarizam com os nomes e sons de letras, a capacidade de se beneficiarem de relações feitas entre escrita e som motivadas pelo alfabeto melhora.

9 Tradução livre da autora: "Quando a escrita faz sentido a base dos nomes das letras-como com nossas palavras inventadas como BT para "beet" e palavras reais como como Jane, deep e eel-até crianças pequenas conseguem começar a compreende-las.
} 


\subsection{Pressupostos gerais da psicologia genética e o que consideram pré-requisitos para a alfabetização}

Esta perspectiva teórica se distingue da perspectiva cognitiva em muitos aspectos. $\mathrm{O}$ primeiro deles é em relação à concepção que se tem do objeto de pesquisa - a escrita - e o segundo em relação à concepção dos sujeitos da aprendizagem - as crianças.

\subsubsection{A escrita como representação}

Representantes da postura psicogenética (Emília Ferreiro e Teberosky, 1999; Goodman, 1976; Harris, 1986; Zamudio, 2008) consideram que ao identificarmos a escrita como mera transcrição da linguagem oral é necessário pressupor tanto que a escrita é secundária à linguagem oral quanto que as palavras ou as letras sejam referentes a estes símbolos, sem levar em consideração a natureza desigual dessas categorias. Para Sampson ( 1997, p. 28)

es crucial en el estudio de los sistemas de escritura mantener siempre presente la idea de que una escritura es solo un dispositivo para hacer visibles los ejemplos de la lengua; la escritura en sí misma no es la lengua. Una lengua puede escribirse en diferentes escrituras y la misma escritura puede utilizarse para escribir diferentes lenguas. ${ }^{10}$

De acordo com Harris (1999, p.86), "el signo escrito es un producto contextual; en consecuencia, los sistemas de escritura diferirían entre sí en función de los diversos tipos de actividad que integren" ${ }^{11}$. E para Olson (1988, p. 113):

la escritura no es la transcripción del habla, antes bien proporciona un modelo conceptual para ese habla. (...) Los sistemas de escritura representan efectivamente el habla, pero no en el modo que se suele creer. Crean categorías en función de las cuales somos conscientes del habla. ${ }^{12}$

Zamudio (2004) sustenta que tanto as hipóteses que as crianças apresentam sobre a linguagem escrita antes de ingressar à escola quanto a diversidade de sistemas de escrita criados ao longo da história são aspectos que contradizem a consideração de que a escrita seja a codificação gráfica da linguagem oral.

\footnotetext{
10 Tradução livre da autora: é crucial no estudo dos sistemas de escrita manter sempre presente a ideia de que uma escrita é somente um dispositivo para fazer visíveis os exemplos da língua; a escrita em si mesma não é a língua. Uma língua pode ser escrita em diferentes escritas e a mesma escrita pode ser utilizada para escrever diferentes línguas.

11 Tradução livre da autora: o signo escrito é um produto contextual. Consequentemente, os sistemas de escrita diferem entre si em função dos diversos tipos de atividades que os integram.

12 Tradução livre da autora: a escrita não é a transcrição da fala, antes disso, ela proporciona um modelo conceitual para essa fala. (...) Os sistemas de escrita representam efetivamente a fala, mas não da forma que se costuma acreditar. Criam categorias em função das quais somos conscientes da fala.
} 
A história do desenvolvimento da escrita nos mostra a dificuldade encontrada para conseguir separar o significante do significado, tarefa sob a qual se debruçaram sumérios, assírios, chineses, japoneses, persas, egípcios, fenícios, hebreus e árabes ao longo de muitos séculos. Isso porque a escrita desenvolvida até então preocupava-se em representar integralmente a linguagem, de maneira logográfica ou silábica, nas quais cada elemento gráfico correspondia a um signo linguístico (de acordo com Saussure, cada signo é composto por um significante sonoro e seu respectivo significado). Contudo, essa forma de representação possuía limitações importantes: uma era a de inventar caracteres para representar nomes próprios, e a outra é que esse tipo de escrita produzia uma quantidade enorme de elementos gráficos, gerando uma enorme carga para a memória, já que demandava um desenho para cada palavra da língua.

Para resolver isso, algumas escritas logográficas usavam o mesmo símbolo para palavras cujos significados estavam de algum modo relacionados (sol, brilho, calor, por exemplo) - o que é conhecido como princípio ideográfico; e outras usavam o mesmo caractere para palavras cujos signos linguísticos fossem iguais ou semelhantes (mão, cão, vão, por exemplo) - o que é conhecido como princípio de rebus.

Contudo, além da ambiguidade provocada (pois embora o contexto em que a grafia se inseria ajudasse a inferir seu sentido, muitas vezes este era insuficiente para saber qual interpretação dar à escrita), o princípio de uma grafia para cada signo que regia esse tipo de escrita estava ameaçado.

Uma solução foi a de agregar outros caracteres que especificassem melhor a interpretação de como a leitura deveria ser feita, já que fariam alguma alusão a respeito da pronunciação. Ou seja, um composto que forma uma unidade escrita que faz referência tanto ao significado quanto ao som (Zamudio, 2004).

De modo semelhante se desenvolve a construção do sistema de escrita por parte da criança que aprende a ler e a escrever. Antes de prestar atenção à representação do som, a criança observa outros aspectos da escrita e cria hipóteses, desde a sua função (creem inicialmente que serve para nomear objetos) até a sua organização (para representar objetos diferentes não se pode usar os mesmos caracteres e que a quantidade de caracteres é um elemento que também marca essa distinção).

Tanto en la historia como en la psicogénesis de la lengua escrita se observan procesos de conceptualización complejos, en los cuales la centración en los sonidos (el principio fonográfico), lejos de ser una guía inmediata o primaria en la construcción de las 
escrituras, es el resultado de la exploración de otras posibilidades de representación ${ }^{13}$. (Zamudio, 2004, p. 172)

Ou seja, a possibilidade de isolar um segmento sonoro é posterior à consideração do significado de alguns elementos gráficos (diferenciação com desenhos, quantidade e variabilidade dos caracteres).

Para aprender a ler e a escrever, portanto, a criança deverá se debruçar sobre a linguagem escrita buscando compreender o que ela significa, como está composta e a organização desses elementos. Neste ponto reside outra diferença com a perspectiva cognitiva. A criança aqui não é concebida como um agente passivo, à espera de que o outro, em geral o adulto, deposite nela seus saberes, mas sim, em termos piagetianos, como um sujeito cognoscente, que tem papel fundamental em seu processo de aprendizagem; ativa na busca de conhecimento, que, ao se defrontar com novas informações, objetos ou realidades, assimila-as, confrontando-as com seus esquemas prévios, e, então, produz uma representação pessoal diferente da que possuía antes e do que lhe tenha sido informado a priori (pelo outro ou pelo meio).

\subsubsection{A construção do conhecimento e o sujeito de aprendizagem}

Piaget (1973) foi um dos pesquisadores dedicados às questões de como ocorre a construção do conhecimento pelas crianças, e os saberes produzidos a partir desse estudo refletem-se, até hoje, nas diferentes áreas do saber.

Esse teórico concluiu, a partir de inúmeras pesquisas, que o conhecimento é produzido a partir das trocas entre o sujeito e o meio. O meio é aqui entendido tanto como o meio físico, social e cultural, como os objetos e demais agentes que os compõem (Piaget, 1971, 1978). Essas trocas são intensas desde o nascimento, mas ficam mais evidentes quando as interações de natureza social começam a ocorrer, mais precisamente durante a primeira infância (entre dois a sete anos, aproximadamente), com o aparecimento da linguagem. Este é o exato período em que, em geral, a criança inicia sua escolaridade.

As interações com o meio permitem ao sujeito, a partir das experiências e dos conhecimentos prévios $^{14}$, reconstruir saberes e se apropriar de novos conhecimentos. Estes são

\footnotetext{
13 Tradução livre da autora: Tanto na história como na psicogênese da língua escrita observam-se complexos processos de conceitualização, nos quais a "centração"*/ concentração na pauta sonora (princípio fonográfico), longe de ser uma guia imediata ou primária na construção da escrita, é o resultado da exploração de outras possibilidades de representação.

*(Segundo a teoria piagetina, centração é a tendência a se concentrar em um aspecto e negligenciar outros).

14 O termo "conhecimentos prévios", alcunhado por (AUSUBEL, Novak, \& HANESIAN, 1980), se refere aos saberes que os alunos dispõem e que serão determinantes para as aprendizagens posteriores. Trata-se daquilo que
} 
experimentados, testados, generalizados, significados e ressignificados nas interações posteriores.

Em outras palavras, o sujeito-aprendiz parte daquilo que já sabe, e, ao interagir com o outro - que tem conhecimentos diferentes -, terá algumas de suas certezas desestabilizadas, provocando um desequilíbrio em sua estrutura inicial; e, na tentativa de acomodar o novo conhecimento ao que ele já tem, produzirá novos saberes.

É óbvio que um estímulo pode eliciar uma resposta somente se o organismo for anteriormente sensibilizado a este estímulo [...] Quando dizemos que um organismo ou sujeito é sensível a um estímulo e capaz de responder a ele, está implícito que ele já possui um esquema ou estrutura à qual este estímulo é assimilado. (Piaget, 1977, p. 77)

Piaget (1967) articula as ideias apresentadas acima quando pressupõe certo funcionamento das estruturas mentais, que se aplica nas diferentes aprendizagens. Qual seja: que o meio representa um desafio, um enigma sobre o qual a criança age, inicialmente de maneira reflexa, mas que, pela repetição e incorporação de novos hábitos e percepções, vai dotando de intencionalidade as suas ações, ao observar as relações de causalidades. Desse movimento (repetição, imitação e exploração de outras possibilidades), surge a linguagem, que aumenta quantitativa e qualitativamente a interação com o meio, fazendo com que este traga cada vez mais novos desafios, sobre os quais as crianças, a partir do que já sabem (conhecimentos prévios), incorporarão novos conhecimentos e construirão outros.

Ainda de acordo com Piaget (1967), o que impulsiona o sujeito a atuar sobre o mundo na tentativa de desvendá-lo é a necessidade de equilíbrio: ele assimila aquilo que vem de fora, o que gera um desconforto, porque não pertence às suas estruturas anteriores, e, no esforço de livrar-se desse desconforto, acomoda o que foi assimilado aos seus esquemas - o que chamou de "processo de equilibração". Desse modo, apropria-se de maneira única de um conhecimento inicialmente externo a ele. Macedo (1994) comparou esse processo ao que ocorre quando jogamos uma pedra em um lago: as águas do lago estão paradas (o que representa as estruturas que o sujeito já construiu), e, ao serem atingidas pela pedra (dado novo), estas produzem ondas em sua superfície, que se propagam até que a pedra seja completamente acomodada ao solo do lago. A pedra não é mais a mesma de antes de ser lançada ao lago, nem o lago é o mesmo após ser atingido pela pedra.

A partir das ideias apresentadas, pode-se inferir que a capacidade de a criança realizar interações de diversas naturezas com sujeitos e objetos - nas quais possa expor suas ideias,

Piaget (1972) chamou de estrutura mental do indivíduo, que será modificada à medida que outros conhecimentos forem incorporados a esta estrutura. Sendo estas, portanto, condições prévias para aprender. 
argumentar, experimentar, reformular etc. - é uma característica estruturante e, portanto, fundamental da construção do conhecimento: “(...) para que um novo instrumento lógico se construa, é preciso sempre instrumentos lógicos preliminares; quer dizer que a construção de uma nova noção suporá sempre substratos, subestruturas anteriores e isso por regressões indefinidas" (Piaget, 1972, p. 20). E ainda que

(...) as relações entre o sujeito e o seu meio consistem numa interação radical, de modo tal que a consciência não começa pelo conhecimento dos objetos nem pelo da atividade do sujeito, mas por um estado diferenciado; e é desse estado que derivam dois movimentos complementares, um de incorporação das coisas ao sujeito, o outro de acomodação às próprias coisas. (Piaget, 1978, p. 386)

As ideias de conhecimentos prévios, interação e, sobretudo, a do processo de equilibração pressupõem um papel ativo por parte do sujeito que aprende. Ao formular a teoria psicogenética, Piaget submeteu à comprovação prática a importância da atividade mental construtiva dos sujeitos nos processos de aquisição do conhecimento - residindo neste aspecto a sua grande contribuição para a concepção de ensino e de aprendizagem.

Conceber a construção de conhecimentos deste modo implica um novo olhar sobre a relação ensino e aprendizagem no âmbito escolar. Se as interações entre os sujeitos e entre estes e os objetos de conhecimento se constituem como fundamentais no processo de aprendizagem, a escola e o professor ganham novas funções e papéis. Além disso, instaura-se a demanda de se repensar a utilidade daqueles conhecimentos tidos como pré-requisitos à aprendizagem, que, no caso da leitura e da escrita, seriam a correspondência grafo-fônica, o traçado e o reconhecimento do nome da letra.

\subsubsection{Processo de alfabetização}

Tradicionalmente, a palavra "alfabetização" foi concebida para designar a aquisição do código escrito - que ocorria quando a criança dominava a técnica de codificar a linguagem oral (escrever) e decodificar o escrito (leitura). No entanto, Ferreiro e Teberosky (1999) observam que não existe um momento preciso, desvinculado das experiências anteriores e resultado de um conjunto de técnicas, que culmine com o domínio da língua escrita.

(...) se a escrita é concebida como um código de transcrição, sua aprendizagem é concebida como a aquisição de uma técnica; se a escrita é concebida como um sistema de representação, sua aprendizagem se converte na apropriação de um novo objeto de conhecimento, ou seja, em uma aprendizagem conceitual. (Ferreiro, 2010, p. 19) 
Segundo essas autoras, aprender a ler e a escrever - alfabetizar-se - é um processo mais amplo e complexo, abarcando a aprendizagem do sistema de escrita, mas não se restringindo a apenas isso. Concebem a alfabetização como a apropriação e a ampliação do conhecimento sobre a língua escrita e, por isso, como um processo que começa antes mesmo de a criança ingressar na escola e que prossegue mesmo após a sua conclusão, à medida que continua construindo saberes neste campo.

Desde o seu nascimento, a criança é inserida em uma cultura letrada. Uma cultura que utiliza a escrita em diversas situações para comunicar, informar e divertir (livros, revistas, televisão, computador, receitas, placas de rua e de estabelecimentos, embalagens etc.). Assim como os demais objetos de conhecimento que compõem o universo infantil, a escrita também é alvo de reflexão e indagação; sobre a qual a criança cria hipóteses a respeito de sua natureza e função.

Imersa em um mundo onde há a presença de sistemas simbólicos socialmente elaborados, a criança procura compreender a natureza destas marcas especiais. Para tanto, não exercita uma técnica específica de aprendizagem. Como já fez antes, com outros tipos de objetos, vai descobrindo as propriedades dos sistemas simbólicos por meio de um prolongado processo construtivo. (Ferreiro, 2010, p. 44)

Os conhecimentos construídos acerca da linguagem escrita são parte constitutiva fundamental do processo de alfabetização, é o que motiva e significa a aprendizagem do sistema notacional. "Notação" é o termo utilizado por Teberosky e Tolchinsky (2008), bem como por Sinclair (1990) e outros autores, para designar os sinais gráficos convencionais, "usados para registrar e transmitir informação (...). O conhecimento notacional consiste na capacidade de reconhecer, interpretar e produzir distintas formas notacionais" (Teberosky e Tolchinsky, 2008, p. 9). Aprender a notação convencional consiste em uma parte do processo de apropriação da linguagem escrita, que influi e é influenciada pelas conceitualizações da criança.

A alfabetização é, portanto, de acordo com essa perspectiva, um processo permanente de compreensão e produção de linguagens e sistemas de escrita. Engloba um conjunto de atividades que procuram fazer com que as pessoas de diversas culturas e grupos sociais se apropriem do complexo objeto que é a escrita (Castedo, 1997).

Ferreiro e Teberosky (1999, p. 22) sustentam que durante o processo de compreensão do sistema de escrita,

Três períodos fundamentais podem ser identificados, no interior dos quais é possível indicar subníveis. 1) O primeiro período caracteriza-se pela busca de parâmetros de diferenciação entre as marcas gráficas figurativas e as marcas gráficas não-figurativas, assim como pela formação de séries de letras como objetos substitutos, e pela busca das 
condições de interpretação desses objetos substitutos. 2) O segundo período é caracterizado pela construção de modos de diferenciação entre os encadeamentos de letras, baseando-se alternadamente em eixos de diferenciação qualitativos e quantitativos. 3) O terceiro período é o que corresponde à fonetização da escrita, que começa por um período silábico e culmina no período alfabético.

Após o período inicial de diferenciação entre o que é escrita e o que é desenho inicia-se o segundo período, em que as crianças focam o olhar no texto e buscam critérios que o tornem legível, como a quantidade mínima de caracteres e a variabilidade destes, para que seja considerada uma escrita.

No início desse período as crianças ainda não atentam para o fato de que a escrita representa a linguagem oral, mas a necessidade de estabelecer melhores critérios para escolher as letras necessárias para a escrita de um nome possibilita-lhes perceber que as emissões orais podem corresponder às partes gráficas, entrando, assim no terceiro período, descrito por Ferreiro (2002) como fonetizante, que se inicia com o período silábico e termina com o alfabético (Alvarado, 1997).

Esse período provoca uma desestabilização dos critérios de legibilidade, de quantidade mínima e variabilidade, anteriormente estabelecidos pelas crianças. Para escrever monossílabos e dissílabos, por exemplo, apenas um ou dois caracteres seriam conflitantes com sua hipótese anterior, bem como palavras compostas por sílabas que possuem o mesmo núcleo, como BARRACA, em que a representação silábica dos respectivos núcleos seria AAA. Nesse período observamos três momentos: silábico, sem valor sonoro convencional (SSVSC), silábico com valor sonoro convencional (SCVSC), e silábico-alfabético (SA).

No período SSVSC, as crianças compreenderam que as partes que percebem no oral (sílaba) correspondem a partes gráficas e atribuem letras de maneira arbitrária. O período seguinte, SCVSC, inicia quando as crianças começam a perceber o valor sonoro convencional da sílaba, atribuindo, a cada uma, uma letra que corresponde a um dos sons que compõem a sílaba (vogal ou consoante).

Essa hipótese se desestabiliza ao ser confrontada com a produção adulta, que possui maior quantidade de letras, e, ao tentar escrever palavras cujas sílabas têm o mesmo núcleo silábico (CABANA, por exemplo) - para atender o critério de variabilidade, a criança precisa acrescentar alguma letra, usando mais de uma grafia para representar cada sílaba. Este é o período silábico-alfabético (Ferreiro, 2009).

Por fim, quando as crianças passam a utilizar de maneira convencional tanto as vogais quanto as consoantes para representar o segmento silábico é considerado que ela atingiu o 
período alfabético, compreendendo o princípio que rege nosso sistema de escrita: de que cada letra corresponde a um ou poucos sons, e que um som corresponde a uma ou poucas letras - de acordo com o grau de transparência de cada idioma.

Para aprender a criança tem que identificar os elementos que estão presentes e entender a forma como eles se relacionam, entender o que a escrita representa e como representa, e isso requer um processo de construção que permita ao sujeito apropriar-se das características do sistema e das relações que guardam seus elementos (Ferreiro, 1997; Ferreiro e Teberosky, 1999).

\subsection{4 "Pré-requisitos" para aprendizagem da escrita em uma perspectiva psicogenética}

A partir da perspectiva cognitivista, a alfabetização depende

de la suma de información adquirida en los entrenamientos sobre el manejo de unidades sonoras y su relación con su contraparte gráfico (conocer el abecedario, el nombre de cada una de las letras y la equivalencia fonológica que representa) (Fernández, 2015, p.27)

As pesquisas dessa perspectiva querem averiguar se as crianças são capazes de identificar, apagar, incluir, trocar ou segmentar as unidades linguísticas pré-estabelecidas (fonema, ataque e rima ou sílaba), e, para isso, listam as habilidades, sem considerar os erros que cometem, sem analisar as respostas não esperadas - não observam o desenvolvimento evolutivo da consciência fonológica, nem os desafios que as crianças enfrentam para adquirir as habilidades em questão. Não consideram o conhecimento que as crianças têm sobre a escrita e as pesquisas são feitas mediante tarefas orais:

Es decir, se plantean tareas donde se presenta un estímulo auditivo (generalmente pseudopalabras con el objetivo de evitar los niños se centren en los significados) y luego se pide que realicen alguna operación de tipo fonológico (omitir, agregar, segmentar). Los estudios realizados con escritura se centran en el reconocimiento de palabras escritas $^{15}$. (Cano e Vernon, 2008, p.15)

Já a perspectiva da psicologia genética concebe a escrita como um sistema de representação no qual alguns elementos da linguagem oral se conservam, outros se perdem,

\footnotetext{
15 Tradução livre da autora: Ou seja, propõem-se tarefas nas quais se apresentam um estímulo auditivo (geralmente pseudopalavras com o objetivo de evitar que as crianças se concentrem nos significados) e logo pede-se que realizem alguma operação de tipo fonológico (omitir, agregar, segmentar). Os estudos realizados com escrita detém-se no reconhecimento da palavra escrita.
} 
outros se somam e outros se transformam. Portanto, nem os elementos, nem as relações estão pré-determinados: a representação não é igual ao objeto representado.

Por essa razão, a possibilidade de as crianças perceberem e poderem utilizar a informação escrita, seja ela a identificação do fonema ou o conhecimento do nome das letras, depende fundamentalmente do momento conceitual que elas se encontram. Essas habilidades, portanto, não se configurariam como pré-requisitos para a aprendizagem da leitura e da escrita, mas sim algo que as crianças descobrem à medida que refletem sobre a escrita; e que ao mesmo tempo potencializa e ressignifica a aprendizagem, em um processo mais dialógico e menos linear (Vernon, Alvarado, e Calderón, 2001; Vernon e Calderón, 1999).

Desse modo, podemos concluir que o único pré-requisito que esta perspectiva coloca para a aprendizagem do sistema de escrita é que sejam oferecidas às crianças oportunidades de muitas e variadas situações em que possam refletir sobre a escrita, experimentando e testando suas hipóteses, confrontando-as com as de seus parceiros e de portadores de circulação social, e tendo a possibilidade de novamente experimentar, ler e escrever por si só e com o outro, ainda que não o façam de maneira convencional.

Diversos autores dessa linha de investigação (Calderón, 2004, 2010; Ferreiro, 2000, 2007; Ferreiro, 2013; Zamudio, 2004, 2008) pesquisaram sobre a relação do desenvolvimento da escrita e a consciência fonológica, enquanto outros (Cano e Vernon, 2008; Quinteros, 1997; Vernon, 2001; Vernon e Calderón, 1999) focalizaram seus estudos no conhecimento do nome da letra, com o objetivo de verificar se este se configura de fato como um pré-requisito para a aprendizagem da leitura e da escrita.

Como o propósito desta dissertação é compreender o uso que as crianças pré-alfabéticas fazem do conhecimento que têm sobre o nome da letra em situações de escrita e de completar palavras, a seguir nos deteremos em revisar os aportes dessa linha de pesquisa.

Durante muito tempo, os estudos a respeito da alfabetização estiveram fortemente ligados apenas ao desenvolvimento da consciência fonológica como aspecto fundamental e estruturante para a aprendizagem do sistema de escrita. Após o impacto da psicogênese da língua escrita, estudos da tradição cognitivista retomam essa abordagem destacando o conhecimento do nome das letras ( Cardoso-Martins, 2001; Pollo et al., 2005a; Treiman, 1994).

$\mathrm{Na}$ perspectiva genética, considera-se que para compreender o sistema alfabético é necessário que a criança reflita sobre a linguagem oral e sua relação com a linguagem escrita. Essa postura implica que a partir de uma estruturação do escrito, a criança reestruture o oral, já 
que a escrita não é apenas um código de transcrição da fala, mas sim um subsistema linguístico, que, como tal, tem suas especificidades.

Diversos autores de corte psicogenético, como Calderón (2004); Cano e Vernon (2008); Ferreiro (2002); Quinteros (1997); Teberosky e Martinez (2003), entre outros, investigaram a relação entre o conhecimento do nome da letra e o conhecimento do sistema de escrita alfabético.

No estudo de Quinteros (1997), a autora indaga sobre os mecanismos que levam as crianças pré-alfabetizadas a escolherem as letras que utilizam em suas produções. A autora observou que a sílaba foi a unidade de análise utilizada no momento de escrever e que a função que as crianças atribuem às letras muda em função do nível de conceitualização que têm do sistema de escrita.

(...) las conceptualizaciones de los niños sobre cómo opera el sistema de escritura y los conocimientos que logran construir sobre sus elementos son variables que interactúan entre sí, produciendo formas diferentes de notar a la palabra y formas de centración en la sílaba oral. (Quinteros, 1994, p. 6) ${ }^{16}$

Mas somente após compreenderem a organização do sistema de escrita e a correspondência com o oral é que as crianças serão capazes de perceber as unidades vogais ou consoantes nas palavras ou no nome da letra.

Em consonância, Ferreiro (2002) defende que a possibilidade de segmentar a oralidade, de analisar a linguagem oral, surge como resposta a um problema cognitivo, e que a utilidade do conhecimento do nome da letra depende tanto do nível conceitual da criança quanto das características particulares do sistema de escrita de cada idioma e das variações dialetais dentro de uma mesma língua. Nesse sentido, rechaça tanto a ideia de que o conhecimento do nome da letra seja um pré-requisito para a aquisição do sistema de escrita quanto de que seja estável durante todo o processo de aprendizagem (Ferreiro, 2002, p. 160).

Alvarado (1997), Vernon (1997a) e Vernon et al. (2001) apontam que, como a relação sonoro-gráfica das palavras não é evidente, a utilidade da informação sobre o nome das letras pode variar de acordo com o momento conceitual e a característica fonológica do idioma.

Além do nível de escrita, Alvarado (1997) observou que as respostas das crianças em estágio fonetizante também estavam condicionadas à presença de material escrito: tinham maior possibilidade de analisar a linguagem oral mediante a respectiva grafia. Isso mostra que as

\footnotetext{
${ }^{16}$ Tradução livre da autora: (...) as conceitualizações das crianças sobre como funciona o sistema de escrita e os conhecimentos que conseguem construir sobre seus elementos são variáveis que interagem entre si, produzindo formas diferentes de escrever a palavra e formas focalização na sílaba oral.
} 
crianças são capazes de utilizar as informações contidas no sistema de escrita antes de poderem ler e escrever convencionalmente.

\section{Conhecimento do nome da letra na perspectiva da pesquisa psicogenética}

Em relação ao conhecimento do nome da letra, Alvarado (1997) encontrou uma alta porcentagem de respostas corretas na identificação de letras, sendo que o reconhecimento das vogais se sobrepôs ao das consoantes. Contudo, embora muitas crianças fossem capazes de identificar muitas letras, isso não significou que puderam utilizá-las para escrever espontaneamente.

No entanto, diversas crianças, que nomearam a letra pelo respectivo fonema, a utilizaram ao escrever, atribuindo-lhe o valor silábico convencional (por exemplo, apesar de nomear $\mathrm{M} \mathrm{com} / \mathrm{m} /$ ao escrever 'mariposa', usou o M para representar o MA). Esse resultado parece apontar que, para as crianças, as letras podem ter diferentes valores, já que "sirven para representar varios sonidos (fonema o sílaba) o si se la letra puede tener nombres distintos" 17 (Alvarado, 1997, p. 46).

A forma como as crianças identificaram as letras também variou nesse estudo e teve relação com o nível de escrita: nomearam a letra por seu respectivo fonema (crianças alfabéticas); nomearam a letra por seu respectivo fonema ou sílaba inicial (silábicosalfabéticos); nomearam a letra por sua respectiva sílaba inicial (silábicos com ou sem valor convencional). Ao observar as letras identificadas e as formas como foram identificadas, a autora concluiu que:

(...) encontramos que letras como " $S$ " y " $M$ " fueron denominadas de acuerdo con el valor fonético correspondiente. Esta situación abre la probabilidad de considerar que los niños podrían incorporar convencionalmente letras que representan fonemas con algunos rasgos fónicos particulares (por ejemplo continuidad) con mayor facilidad en su escritura. ${ }^{18}$ (Alvarado, 1997, p. 46)

Também observou que algumas características fonológicas das consoantes pareceram influenciar sua identificação, já que consoantes como $/ \mathrm{m} / \mathrm{e} / \mathrm{s} /$ foram nomeadas com maior

\footnotetext{
17 Tradução livre da autora: "servem para representar vários sons (fonemas ou sílabas) ou se uma mesma letra pode ter diferentes nomes.

18 Tradução livre da autora: (...) encontramos que letras como "S" e "M" foram denominadas de acordo com o valor fonético correspondente. Esta situação abre a possibilidade de considera que as crianças poderiam incorporar convencionalmente letras que representam fonemas com algumas características fonéticas particulares (por exemplo, continuidade) com maior facilidade em sua escrita.
} 
facilidade. A estrutura da palavra também pareceu ser um fator importante, bem como a facilidade para identificar os núcleos silábicos nas palavras.

A autora identifica também que a possibilidade de produzir escritas com valor sonoro convencional influenciou positivamente a realização da tarefa de omissão do primeiro segmento; já a possibilidade de identificação não parece ter exercido influência.

En los datos obtenidos no pudimos encontrar relación entre la posibilidad de identificar letras iniciales y el desempeño de los niños con amplia información sobre el valor de las letras, sus respuestas se ven condicionadas por sus concepciones sobre el sistema de escritura más que con el conocimiento de las letras en lo particular. En otras palabras, al momento de resolver la tarea de omisión influye más la información que los niños pueden efectivamente utilizar al escribir que aquellos conocimientos que sólo les permite reconocer la letra pertinente ${ }^{19}$ (Alvarado, 1997, p. 46)

Vernon (1997b, 2005) observou que a possibilidade de crianças hispano-falantes analisarem a linguagem oral se desenvolve de maneira ordenada: inicialmente consideram a palavra como um todo e não podem realizar recortes nela; em seguida, realizam recortes silábicos em palavras que possuem mais de uma sílaba, utilizando o núcleo desta para marcar a fronteira entre uma sílaba e outra; após esse momento, começam a fazer uma análise intrassilábica, isolando a vogal da consoante. Nesse momento, Vernon (1997b, 2005) observou que quando a criança tentava segmentar uma consoante oclusiva era frequente a substituição por uma consoante menos oclusiva.

Além disso, Vernon (1997b e 2005) destaca que sendo a escrita um sistema de representação de uma língua, a estrutura de cada idioma colocará limitações às análises que podem ser feitas dela. Por isso, entender bem a estrutura de uma língua, suas especificidades fonológicas e ortográficas, ajuda a compreender o processo cognitivo envolvido.

Na pesquisa de Calderón (2004), as crianças não tiveram dificuldade para identificar as letras por seus respectivos nomes, e essa capacidade, em realidade, pareceu dificultar as crianças na realização da tarefa de consciência fonológica. Também observou que as crianças alfabéticas, quando omitiam letras em escritas regulares (CV), frequentemente omitiam as vogais. Nas situações em que faziam substituições, normalmente trocavam a vogal correta por outra vogal, e quando trocavam a consoante, a troca era por outra consoante. As trocas, porém,

\footnotetext{
${ }^{19}$ Tradução livre da autora: Nos dados obtidos não podemos encontrar relação entre a possibilidade de identificar letras iniciais e o desempenho das crianças com ampla informação sobre o valor das letras, suas respostas estavam mais condicionadas por suas concepções sobre o sistema de escrita do que pelo conhecimento do nome da letra em particular. Em outras palavras, no momento de resolver a tarefa de omissão, influenciou mais a informação que as crianças podem efetivamente utilizar ao escrever que aqueles conhecimentos que só os permite reconhecer a letra pertinente.
} 
não eram aleatórias, mas seguiam critérios gráficos ou sonoros - as letras trocadas guardavam semelhanças com as convencionalmente correspondentes.

Cano e Vernon (2008) fizeram uma pesquisa, com o propósito de explorar o tipo de informação que as crianças em processo de alfabetização têm sobre as letras, como relacionam estas informações e quais informações são úteis no momento de escrever ou completar palavras. A pesquisa privilegiou a análise das consoantes cujos contextos silábicos coincidissem com o nome da letra (motivação fonológica).

A autora observou que uma variável importante foi o contexto silábico, pois as consoantes acompanhadas de /i/, /o/ ou /u/ eram com maior frequência utilizadas de forma equivocada. Além disso, as letras motivadas fonologicamente aparentemente favoreceram a utilização da consoante correta, sobretudo, quando compunham as sílabas iniciais, isso porque "es el primer recorte (usualmente silábico) o por la facilidad para relacionarlo con un referente" ${ }^{20}$ (Cano e Vernon, 2008, p. 95). Notou também que outro ponto que facilitava a utilização da consoante correta era uma variável relacionada à característica fonética do fonema representado pela letra: as letras que representam fonemas mais contínuos parecem ser mais facilmente isoláveis e identificáveis. Desse modo,

(...) parecería que una diversidad de denominaciones o de contextos de uso facilita la elección de la consonante correcta. Es decir, las posibilidades de usar la letra correcta están relacionadas con la posibilidad de denominar o hacer referencia a la letra de maneras variadas. Es decir, cuando un niño puede ligar el contexto silábico particular a otras sílabas o palabras en las que la letra en cuestión aparece, será más factible que logre usar la letra correcta ${ }^{21}$ (Cano e Vernon, 2008, p. 95)

Ou seja, tanto reconhecer a letra por seu nome, quanto pelo fonema, quanto por outros referentes (nomes próprios ou palavras familiares) foram informações pertinentes e relevantes durante o processo de alfabetização.

(...) una gran cantidad de niños hacen uso de referentes (nombres propios o palabras familiares) como forma de denominar las letras, de manera que los referentes les proporcionan información que permite guiar la escritura de fragmentos de una palabra al ayudarlos a asociar partes orales y/o escritas a una palabra completa(...) $)^{22}$ (Cano e Vernon, 2008, p. 95)

\footnotetext{
${ }^{20}$ Tradução livre da autora: é o primeiro recorte (usualmente silábico) ou pela facilidade para o relacionar com um referente.

${ }^{21}$ Tradução livre da autora: (...) aparentemente uma diversidade de denominações ou de contextos de uso facilita a escolha da consoante correta. Ou seja, as possibilidades de usar a letra correta estão relacionadas com a possibilidade de denominar ou fazer referência a letra de maneiras variadas. Ou seja, quando uma criança pode relacionar o contexto silábico particular a outras sílabas ou palavras nas quais a letra em questão aparece, será mais factível que consiga usar a letra correta.

${ }^{22}$ Tradução livre da autora: (...) uma grande quantidade de crianças fazem uso de referentes (nomes próprios ou palavras familiares) como forma de denominar as letras, de maneira que os referentes lhe proporcionem
} 
Os referentes parecem servir de apoio às crianças ao buscarem estabelecer relações entre a totalidade e as partes, permitindo-as perceber o uso convencional das letras.

Cano e Vernon (2008) observaram que, embora os fonemas fossem utilizados mais frequentemente para denominar os nomes das letras, a sílaba foi a mais utilizada na tarefa de escrita, bem como as palavras de uso frequente utilizadas para escrever estas sílabas. Por isso, concluíram que tanto os fonemas quanto os nomes das letras, assim como as sílabas iniciais, como referentes são informações pertinentes tanto para a escrita de palavras quanto para a identificação de letras.

Esta conclusão está em consonância com o que foi descrito por Ferreiro e Teberosky (1999) quando os autores falaram sobre a importância do nome próprio no momento da alfabetização inicial. Este atuaria como um protótipo da escrita, aportando informações sobre a organização do sistema de escrita, suas letras e combinações. Posteriormente, Ferreiro, Gómez Palacios e col. (1982) apontaram que a aquisição do valor convencional das letras se dava de maneira posterior ou simultânea à aprendizagem da escrita do nome próprio.

\subsection{Trabalhos sobre a aquisição da leitura e escrita em português-brasileiro}

No Brasil há uma carência enorme de pesquisas sobre o processo de aprendizagem a partir da perspectiva psicogenética e o mesmo vale para a pesquisa didática. Contudo, há muitos anos o tema da alfabetização ocupa o centro dos debates educacionais e cada vez mais a sociedade tem discutido e se indignado com a qualidade do ensino no país. É justo afirmar, no entanto, que os investimentos políticos feitos nesta área se limitam a remediar as consequências, não tratando dos problemas estruturais que as desencadeiam. Em decorrência deste pouco caso e da falta de comprometimento, alguns dos profissionais da área se veem à deriva em um sistema que não os forma adequadamente, não os remunera satisfatoriamente, e nem tampouco fornece a infraestrutura necessária para o trabalho.

Como resultado desse processo, muitos professores colocam-se à espera de "lançamentos pedagógicos" que solucionem todos os seus problemas didáticos - professores que estão assujeitados de seu próprio processo de construção de conhecimento, que aplicam acriticamente aquilo que julgam compreender sobre as pesquisas, propostas, modelos e novidades educacionais. Em outros casos, encontramos profissionais comprometidos que

informações que permitam guiar a escrita de fragmentos de uma palavra ao ajudá-las a associar partes orais e/ou escritas a uma palavra completa (...) 
buscam estruturar suas práticas docentes considerando as pesquisas teóricas e as didáticas, que tomam o aluno como sujeito do processo de construção de conhecimentos. Tais profissionais, porém, não encontram, por vezes, um ambiente de interlocução e tampouco um respaldo para refletir, avaliar e repensar as situações de ensino e suas intervenções.

O mais grave é que esses modus operandi generalizaram-se em nossa sociedade, chegando mesmo a serem reconhecidos como algo próprio da cultura escolar, tanto no âmbito público quanto no privado.

Pode-se avaliar como alarmante, também, a quantidade de escolas que são definidas a partir de um suposto referencial teórico adotado, sem que, no entanto, haja preocupação com a coerência de suas práticas em relação a esse referencial. Mais ainda, quando não se responsabilizam pelas diferentes "correntes" que seus professores adotam, quando estes o fazem: em uma mesma escola é possível encontrar salas de aula com professores atuando a partir de concepções de ensino tão diferenciadas que até se colocam como divergentes, sem considerar o percurso do aluno, que segue pelas diferentes séries sem que exista a mínima coerência entre as propostas pedagógicas ou mesmo entre a visão de aprendizagem e sujeito de aprendizagem dos vários professores com quem interage.

Em decorrência da falta de pesquisa acadêmica, a não consistência teórica tornou-se uma das marcas da educação escolar brasileira da atualidade, pois há uma tendência a dar pouca ou nenhuma oportunidade de interação aos profissionais em relação aos estudos sobre as didáticas, distanciando-os da possibilidade de refletir e de compreender melhor o que significa alfabetizar.

A perspectiva construtivista começou a influenciar as concepções de linguagem no Brasil, mais propriamente as de linguagem escrita, a partir da publicação, em 1979, da obra Psicogênese da Língua Escrita, de Emília Ferreiro e Ana Teberosky. Ancoradas nos estudos de Piaget, as autoras, em conjunto com outras pesquisadoras, dedicaram-se a investigar como a criança constrói o saber sobre a língua escrita.

Esse estudo trouxe um novo aspecto para o debate sobre a alfabetização, que até então acontecia apenas no sentido de definir qual seria o melhor método de ensino a ser adotado. A rede pública, que desde a década de 60 vinha sendo castigada pelo fracasso escolar (representado pela evasão e repetência), principalmente nas séries iniciais, vislumbrou na pesquisa psicogenética a possibilidade de responder a esse problema. É fato que, de início, a inserção das ideias apresentadas por Ferreiro e Teberosky (1999) foi feita de modo abrupto e pouco formativo. De todas as conclusões apresentadas, somente as ideias vinculadas à 
apropriação da escrita alfabética foram trazidas para os professores, ou seja, apenas as ideias sobre as hipóteses construídas pelas crianças chegaram aos docentes. Isso acabou gerando - e é algo que ainda ocorre - distorções no papel do professor alfabetizador e na forma como as contribuições advindas da Psicogênese influenciam a prática de ensino. Em muitos casos, por exemplo, os professores se mantinham usando métodos fechados de alfabetização e "usavam" as hipóteses apenas em caráter avaliativo, a fim de definir quantos alunos escreviam de forma alfabética, quantos de forma silábica etc.

(...) a despeito da amplitude do referencial teórico e das suas implicações para a prática pedagógica, a apropriação da psicogênese em sala de aula acabou configurando-se sob a forma de práticas reducionistas e, não raro, equivocadas. Ansiosos por encontrar alternativas para os dramáticos índices de reprovação e fracasso escolar, muitos professores acabaram fazendo uma transposição demasiadamente direta das situações de pesquisa, trazendo-as para a escola mais como uma metodologia de trabalho do que propriamente como um estímulo à reflexão, ao estudo e ao planejamento de práticas mais compromissadas com o aprendiz (...) muitos educadores lançaram-se avidamente à psicogenética como se ela fosse a solução para todos os problemas da sala de aula (...) surgiram também os 'modismos pedagógicos', práticas inconsequentes e até irresponsáveis, embora não necessariamente mal-intencionadas. (Colello e Luize, 2006, p. 20)

Nas instâncias governamentais, porém, aos poucos houve uma preocupação em salientar a necessidade de mudanças na forma como se ensinava a ler e a escrever e, igualmente, uma preocupação em tornar as contribuições das autoras compreensíveis para os professores. Então, a partir da adoção da perspectiva que fundamentou as novas descobertas na área, uma série de publicações foi produzida pelo Ministério e Secretarias da Educação nos anos de 1990 e distribuída em ampla escala a todos os profissionais da rede.

Apesar de todo esse impacto na educação brasileira, a perspectiva genética teve pouca atenção por parte da comunidade acadêmica, que mostrou-se ressentida pela forma como o construtivismo foi imposto na educação escolar e resistente em investir em pesquisa e estudos dessa natureza.

Em relação especificamente ao tema do presente trabalho, menos ainda se pesquisou a respeito da influência do conhecimento do nome das letras no processo de apropriação da língua escrita. Contudo, como pouco se investiga sobre os processos de construção do conhecimento, sobretudo da leitura e da escrita, é comum encontrar como prática usual das escolas de educação infantil ( 0 a 5 anos) e séries iniciais do fundamental 1 ( 6 e 7 anos) forte investimento do tempo didático para o ensino do alfabeto, como se este saber fosse um pré-requisito para aprender a ler e a escrever. 
A única pesquisa encontrada, de corte psicogenético, que aborda o tema do conhecimento do nome da letra - ainda que suscintamente, já que este não era o foco do trabalho - é a tese de doutorado realizada por Scarpa (2014). O objetivo desse estudo foi o de observar quais conhecimentos sobre a língua escrita têm as crianças provenientes de família de baixa renda ao final da Educação Infantil e analisar qual a influência de diferentes propostas didáticas nesse conhecimento. Para isso, pesquisou-se crianças provenientes de quatro escolas periféricas da cidade de São Paulo, que possuíam diferentes perspectivas a respeito do que significa o ingresso da criança na cultura do escrito. Duas escolas desenvolviam práticas atreladas à apresentação gradual e sequenciada das letras (grupo1); e duas consideravam a leitura e a escrita como objeto cultural e por isso as propostas relacionadas apareciam atreladas a contextos reais e significativos de uso (grupo 2).

De acordo com os resultados, as crianças do grupo 2 apresentaram maior êxito em todas as diversas tarefas realizadas (tarefa de escrita do nome próprio, tarefa de escrita de lista de palavras, tarefa de conhecimento do nome das letras, tarefa de leitura de títulos de uma série de subtarefas encadeadas, tarefa de exploração de livros informativos e tarefa de exploração de livros literários).

$\mathrm{Na}$ tarefa de conhecimento do nome da letra fora de contexto, a autora identificou que, embora as escolas do grupo 1 tivessem como eixo do trabalho o ensino dos nomes das letras, as crianças desse grupo conseguiram identificar menos letras que as crianças do grupo 2, no qual não existiam propostas dessa natureza. Em relação entre o conhecimento do nome da letra com o nível de conceitualização da escrita, Scarpa (2014) observou que os aspectos formais da escrita, no caso, o conhecimento do nome da letra, não se configuraram como uma condição para que as crianças evoluíssem conceitualmente em suas análises do escrito. Nesse sentido, encontrou crianças pré-silábicas que conheciam muitas letras e silábicas que conheciam poucas:

(...) a apresentação gradual e sistemática de letras isoladas atreladas aos sons que representam não se mostrou a melhor forma de ensino quando se quer que as crianças aprendam as letras do alfabeto, que, como já mencionamos, embora seja um conhecimento importante, não é pré-requisito para a evolução da compreensão do sistema alfabético de escrita.

Outra vantagem dessa opção didática de não isolar as letras de seus contextos de uso mas de ensiná-las a partir da língua escrita - é de não perder de vista as características do objeto de ensino, isto é, a linguagem escrita é sempre mediada pelas práticas sociais de leitura e escrita. (Scarpa, 2014, p. 155)

Embora não haja muita literatura sobre o tema - segundo a perspectiva psicogenética produzida no Brasil, encontramos inúmeros trabalhos alinhados com a psicologia cognitivista. 
Estes, como já visto anteriormente, partem da ideia de que a escrita é uma transcrição direta do oral, e, por isso, conhecer os elementos responsáveis por essa codificação, no caso, as letras, seus respectivos sons, traçado, e a relação grafo-fônica, é pré-requisito para a aprendizagem da leitura e da escrita.

Diversos autores (Cardoso-Martins e Batista, 2005; Cardoso-Martins et al., 2002; Pollo et al., 2005b, 2008; Treiman et al., 2013) têm defendido que o avanço das possibilidades de escrita está condicionado ao conhecimento que as crianças têm dos nomes das letras, e mais, que as sílabas nas quais ocorre coincidência entre o som da sílaba e o nome da letra (BE soa como B em BEXIGA, por exemplo) são contextos favoráveis para que a criança estabeleça relação entre a parte que se escuta e a respectiva grafia.

Embora essa proposição esteja coerente com o modelo teórico que a sustenta, no qual a alfabetização depende da soma das informações obtidas a partir do treinamento, é objetivo deste trabalho investigar a influência que o conhecimento dos nomes das letras tem partindo de uma perspectiva que considere tanto a atividade cognoscente dos sujeitos de aprendizagem quanto as características do sistema de escrita. Nesse sentido, buscamos especificamente neste trabalho observar e analisar o desempenho de crianças pré-alfabéticas em situações de escrita de palavras e situações de completar palavras e compará-lo ao desempenho obtido na tarefa de identificação de letras fora de contexto. Também foi foco de análise observar o efeito que as letras com motivação fonológica exercem nas respostas das crianças.

É nosso interesse mostrar que essas respostas estão condicionadas pela atividade cognitiva das crianças, pela análise que fazem do sistema de escrita, e que a possibilidade de utilizar a informação grafotática também depende do nível de conceitualização e não o contrário. Ou seja, a informação sobre o nome da letra não é igualmente útil para uma criança que está começando a perceber a relação fonográfica no âmbito da sílaba (esquema de interpretação silábico) e para uma criança que já faz uma análise intrassilábica (esquema de interpretação silábico-alfabético) (Ferreiro, 1997).

\subsection{Características fonológicas do português-brasileiro}

O português-brasileiro, assim como diversos (senão todos) idiomas, possui inúmeras variações linguísticas, ou seja, o modo em que a linguagem se realiza pode mudar em função do momento histórico, do local onde é produzida, do contexto social e da situação (Bagno, 2000). 
Essas variações têm uma classificação específica, de acordo com o âmbito em que sucedem. Quando ocorrem na forma de se escrever uma palavra, provocando uma alteração de grafia, são chamadas de variações morfológicas. Exemplo: algumas palavras antigamente eram acentuadas, como "dôce", que atualmente escreve-se "doce"; a palavra "idéia" era acentuada, hoje não mais; ou o uso do ph, para pharmácia, sendo utilizada hoje em dia com a letra "f" farmácia). Já os casos em que a diferença ocorre na forma de se pronunciar uma letra são chamados de variações fonético-fonológicas (exemplo, a pronúncia dos " $R$ " nas diferentes regiões do estado de São Paulo). Quando ocorrem no plano da significação, ou seja, uma mesma palavra com diferentes significados, chamam-se variações semânticas (exemplo: banco para sentar, banco como instituição financeira). Outra variação é a sintática, associada à forma de se organizar os elementos em uma oração, que pode variar sem a alteração do sentido (exemplo: encontrei ele; o encontrei). Já a variação estilístico-pragmática diz respeito à forma como a comunicação se realiza ao dizer-se de modos totalmente diferentes duas orações e elas possuírem o mesmo significado (exemplo: "retirem-se, por favor" e "Bora ai, galera"). Por fim, a variação lexical consiste em palavras distintas compartilharem o mesmo significado (exemplo: carro e automóvel; casa, lar, residência e moradia; mandioca, macaxeira e aipim; bergamota, mexerica e tangerina etc.).

Muitas dessas variações podem ser observadas somente por meio dos discursos orais, pois a escrita tende a conservar certo padrão na forma de representar a língua, sobretudo no que concerne às variações fonéticas-fonológicas.

A forma como os fonemas se realizam no idioma brasileiro possui uma variação, a depender, sobretudo, da localização geográfica e do contexto social, mas também em função da posição que eles ocupam na palavra. Por exemplo, a palavra BANANA (fruto da bananeira Dicionário Aurélio): em algumas regiões ela pode ser pronunciada como "bá.nã.na" e em outras como "bã.nã.na" ${ }^{23}$. Na região Nordeste, quando a consoante nasal vem no início de uma sílaba, vai sempre interferir na vogal anterior, por isso, as duas consoantes " $\mathrm{N}$ " interferem na nasalização dos dois primeiros “As” de "bÃnÃna”. Já na região Sudeste, a consoante nasal só irá interferir na nasalização da vogal anterior se esta vogal estiver na sílaba tônica. Como em "banana" a sílaba tônica é a sílaba do meio, o fato de ser nasalizada não interfere na nasalização da sílaba anterior.

No entanto, no interior da própria palavra, a realização oral das vogais nas sílabas difere em função da posição ocupada. Embora as três vogais sejam representadas na escrita pela letra

\footnotetext{
${ }^{23}$ Para facilitar o entendimento da pronúncia não foi utilizada a transcrição fonética.
} 
“A”, realizam-se oralmente de três formas diferentes: "á" [a] (gato, lilás), "ã" [ã] (irmã) e "a" [e] (gota). Essa diversidade de realizações que observamos para a letra A é encontrada em $75 \%$ das letras do idioma brasileiro, pois somente 8 letras (B, F, H, J, M, N, P e V), das 24 letras do alfabeto brasileiro (excluindo $\mathrm{W}$ e $\mathrm{Y}$, por não termos palavras com essa letras, exceto as emprestadas de outro idioma e nomes próprios), possuem apenas uma realização fonética, como se pode verificar na Tabela 1.

Tabela 1: Relação de letras do português-brasileiro e as respectivas realizações sonoras (fonemas)

\begin{tabular}{|c|c|c|}
\hline Letra & $\begin{array}{l}\text { Símbolo } \\
\text { fonético }\end{array}$ & Exemplo \\
\hline & [a] & gato, lilás \\
\hline A & $\begin{array}{l}{[\mathfrak{e}]} \\
{[\tilde{\mathfrak{e}}]}\end{array}$ & $\begin{array}{c}\text { Gota } \\
\text { irmã, canto, samba, } \\
\text { amo }\end{array}$ \\
\hline $\mathrm{B}$ & {$[\mathrm{b}]$} & boca, tubarão \\
\hline $\mathrm{C}$ & $\begin{array}{l}{[\mathrm{s}]} \\
{[\mathrm{k}]}\end{array}$ & $\begin{array}{l}\text { cedo, cidade, você } \\
\text { carro, corda, curau, } \\
\text { claro, pacto }\end{array}$ \\
\hline $\mathrm{D}$ & $\begin{array}{l}{[\mathrm{d}]} \\
{[\mathrm{d}]}\end{array}$ & $\begin{array}{c}\text { dado, dedo, vidro } \\
\text { dia, admirar }\end{array}$ \\
\hline & {$[\mathrm{e}]$} & delícia, tema \\
\hline & {$[\mathrm{I}]$} & fome, dorme \\
\hline $\mathrm{E}$ & {$[\varepsilon]$} & café, teto \\
\hline $\mathrm{F}$ & {$[\mathrm{f}]$} & fada, folha \\
\hline $\mathrm{G}$ & $\begin{array}{l}{[\mathrm{g}]} \\
{[3]}\end{array}$ & $\begin{array}{c}\text { gato, guia, grito } \\
\text { gelo, girafa }\end{array}$ \\
\hline $\mathrm{H}$ & mudo & hoje, hora \\
\hline & $\begin{array}{l}{[\mathrm{i}]} \\
{[\mathrm{j}]} \\
{[\tilde{1}]}\end{array}$ & $\begin{array}{l}\text { isto, animal } \\
\text { férias }\end{array}$ \\
\hline I & [î] & limpo, cinto \\
\hline $\mathrm{J}$ & [3] & janela \\
\hline $\mathrm{K}$ & {$[\mathrm{k}]$} & kiwi \\
\hline $\mathrm{L}$ & $\begin{array}{c}{[1]} \\
{[: \mho]}\end{array}$ & $\begin{array}{c}\text { lado } \\
\text { salto, sol }\end{array}$ \\
\hline $\mathrm{M}$ & {$[\mathrm{m}]$} & mato \\
\hline $\mathrm{N}$ & {$[\mathrm{n}]$} & noite \\
\hline
\end{tabular}

\begin{tabular}{|c|c|c|}
\hline Letra & $\begin{array}{l}\text { Símbolo } \\
\text { fonético }\end{array}$ & Exemplo \\
\hline & [o] & tomada, coragem \\
\hline & {$[\circ]$} & Pó \\
\hline $\mathrm{O}$ & {$[v]$} & Mato \\
\hline \multirow[t]{2}{*}{$\mathrm{P}$} & {$[\mathrm{p}]$} & Pato \\
\hline & {$[\mathrm{k}]$} & queijo, quilo \\
\hline \multirow[t]{3}{*}{ Q } & {$[\mathrm{kw}]$} & quando, sequência \\
\hline & {$[r]$} & arara, prisão \\
\hline & {$[\mathrm{x}]$} & roupa, carro \\
\hline \multirow[t]{2}{*}{$\mathrm{R}$} & {$[\mathrm{r}]$} & Carta \\
\hline & {$[\mathrm{s}]$} & sapo, festa, pássaro \\
\hline \multirow[t]{2}{*}{$\mathrm{S}$} & {$[\mathrm{z}]$} & casa, trânsito \\
\hline & $\begin{array}{l}{[\mathrm{t}]} \\
{\left[\mathrm{t} \int\right]}\end{array}$ & $\begin{array}{c}\text { tomada, temida } \\
\text { tia, leite }\end{array}$ \\
\hline \multirow{2}{*}{$\mathrm{T}$} & {$[\mathrm{u}]$} & uva, caju \\
\hline & {$[\tilde{\mathrm{u}}]$} & comum, unha \\
\hline $\mathrm{U}$ & [w] & tênue, quadra \\
\hline \multirow[t]{5}{*}{$\mathrm{V}$} & {$[\mathrm{v}]$} & víbora, verina \\
\hline & {$\left[\int\right]$} & Xícara \\
\hline & {$[\mathrm{ks}]$} & Tórax \\
\hline & {$[\mathrm{s}]$} & Extinção \\
\hline & {$[\mathrm{z}]$} & Caixa \\
\hline \multirow[t]{2}{*}{$\mathrm{X}$} & {$[\mathrm{s}]$} & Excedente \\
\hline & {$[\mathrm{s}]$} & $\mathrm{Paz}$ \\
\hline Z & {$[\mathrm{z}]$} & Zebra \\
\hline
\end{tabular}


Para cada letra é possível uma ou mais realizações sonoras, como visto na Tabela 1, mas também são possíveis outras realizações sonoras a partir da composição de letras, como é o caso da letra L, associada ao H, formando o LH, que se realiza como $[\lambda]$, em "folha", "velhice" etc.; o caso da letra $\mathrm{N}$, associada ao $\mathrm{H}$, formando o $\mathrm{NH}$, que se realiza como [n], em "junho", "bolinha" etc.; a letra G, associada ao U, formando GU, que se realiza como [gw], em "água", "linguiça" etc.

A mesma diversidade ocorre ao considerarmos o fonema, pois no português um mesmo som pode ter mais de uma representação gráfica:

Tabela 2: Relação dos fonemas do português-brasileiro que possuem mais de uma possibilidade de realizações gráficas (letras)

\begin{tabular}{crr}
\hline $\begin{array}{r}\text { Símbolo } \\
\text { fonético }\end{array}$ & Letra & Exemplo \\
\hline \hline & $\mathrm{C}$ & cedo,cidade, \\
você \\
& & $\begin{array}{r}\text { sapo, festa, } \\
\text { consolo, pássaro }\end{array}$ \\
& $\mathrm{S}$ & paz \\
& $\mathrm{Z}$ & extinção \\
\hline $\mathrm{S}]$ & $\mathrm{X}$ & gelo, girafa \\
\hline$[3]$ & $\mathrm{G}$ & janela, jipe, jóia \\
\hline & $\mathrm{J}$ & carro, corda, \\
& & curau, claro, \\
& & pacto \\
& $\mathrm{C}$ & Kiwi \\
& $\mathrm{K}$ & queijo, quilo \\
\hline $\mathrm{K}]$ & $\mathrm{Q}$ & zebra \\
& $\mathrm{Z}$ & caixa \\
& $\mathrm{X}$ & casa, trânsito \\
\hline & &
\end{tabular}

Segundo Frost et al. (1987, p. 104),

“Ortografias alfabéticas podem ser classificadas em função da complexidade com que unidades gráficas mapeiam unidades sonoras. Desse ponto de vista uma escrita transparente possui códigos ortográfico e fonêmico isomórficos; os fonemas que se 
realizam acusticamente na língua falada são representados de maneira direta e inequívoca por grafemas da linguagem escrita. Em contraste, numa ortografia opaca, a relação entre letras e sons é mais turva e menos previsível. A mesma letra pode representar diferentes fonemas em diferentes contextos. Ademais, diferentes letras podem representar o mesmo fonema."

Seymour, Aro, e Erskine (2003) desenvolveram um estudo para determinar o grau de complexidade silábica (predominância de sílabas abertas $-\mathrm{CV}$, sílabas do tipo $\mathrm{CVC}$ e conglomerados complexos de consoantes) e grau transparência/opacidade (correspondência entre os sons e as letras). De acordo com os autores, quanto maior a complexidade silábica (como no inglês, alemão, norueguês, sueco, dinamarquês etc.) e maior opacidade (como o inglês e o francês), maior a dificuldade em relação à aprendizagem da leitura e da escrita. Em relação à transparência/opacidade, desenvolveram uma escala de classificação, sendo 1 mais transparente e 7 menos transparente.

Tabela 3: Grau de transparência de cada idioma analisado por Seymour, P. H. K.; Aro , M; Erskine, J. M., 2003

\begin{tabular}{cc}
$\begin{array}{l}\text { Grau de } \\
\text { transparência/ } \\
\text { opacidade }\end{array}$ & Idioma \\
\hline \hline 1 & Finlandês, italiano, espanhol \\
2 & Grego e alemão \\
3 & Português e holandês \\
4 & Islandês e norueguês \\
5 & Sueco \\
6 & Francês e dinamarquês \\
7 & Inglês \\
\hline
\end{tabular}

A Tabela 4 expõe a complexidade silábica e a profundidade ortográfica (grau de transparência e opacidade), mostrando que quanto mais rasa a profundidade ortográfica, mais transparente é o idioma. De acordo com essa tabela, podemos notar que o português-europeu apresenta sílabas simples e tem profundidade ortográfica média. 
Tabela 4: Classificação hipotética das línguas participantes em relação às dimensões de complexidade silábica (simples, complexa) e profundidade ortográfica (superficial a profunda) ${ }^{24}$

\section{Ortografia}

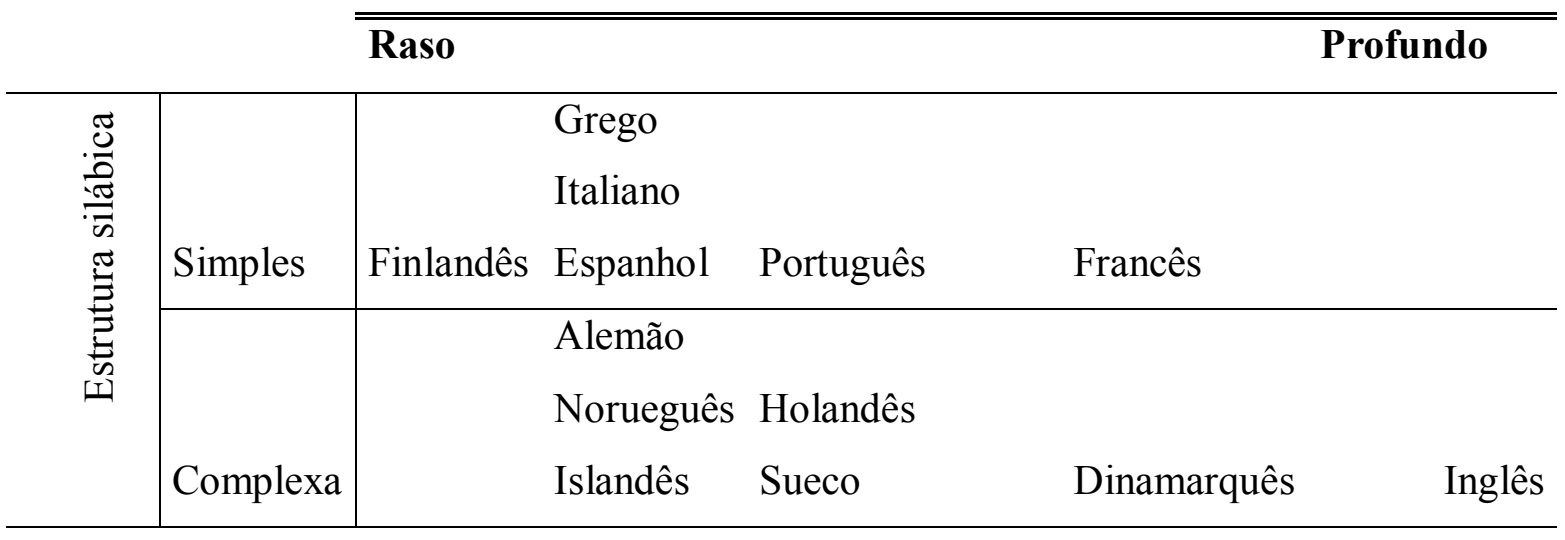

Embora o estudo se refira à análise do português-europeu, ele agrega informações ao português-brasileiro, dada a similaridade entre os idiomas, e está em consonância com o que observamos na análise das letras e dos respectivos fonemas.

Outro aspecto que vale destacar - dado o interesse desta pesquisa sobre a influência do conhecimento do nome da letra - é o modo como as letras são nomeadas em português.

Para representar a escrita no português-brasileiro, usam-se sinais gráficos - as letras - e o conjunto desses sinais é chamado de alfabeto. Este é composto por 26 letras, sendo que, destas, as letras K, W e Y foram inseridas em 1990, pelo Acordo Ortográfico. No entanto, possuem pouca ocorrência, aparecendo fundamentalmente em nomes próprios, abreviaturas ou palavras estrangeiras. As letras, portanto, em sua forma maiúscula e minúscula, são:

Tabela 5 - Alfabeto brasileiro

Forma maiúscula

\begin{tabular}{|l|l|l|l|l|l|l|l|l|l|l|l|l|l|l|l|l|l|l|l|l|l|l|l|l|l|}
\hline A & B & C & D & E & F & G & H & I & J & K & L & M & N & O & P & Q & R & S & T & U & V & W & X & Y & Z \\
\hline
\end{tabular}
Forma minúscula

\begin{tabular}{|l|l|l|l|l|l|l|l|l|l|l|l|l|l|l|l|l|l|l|l|l|l|l|l|l|l|}
\hline $\mathrm{a}$ & $\mathrm{b}$ & $\mathrm{c}$ & $\mathrm{d}$ & $\mathrm{e}$ & $\mathrm{f}$ & $\mathrm{g}$ & $\mathrm{h}$ & $\mathrm{i}$ & $\mathrm{j}$ & $\mathrm{k}$ & $\mathrm{l}$ & $\mathrm{m}$ & $\mathrm{n}$ & $\mathrm{o}$ & $\mathrm{p}$ & $\mathrm{q}$ & $\mathrm{r}$ & $\mathrm{s}$ & $\mathrm{t}$ & $\mathrm{u}$ & $\mathrm{v}$ & $\mathrm{w}$ & $\mathrm{x}$ & $\mathrm{y}$ & $\mathrm{z}$ \\
\hline
\end{tabular}

Entre as 23 letras de ocorrência frequente no português (excluindo, portanto, $\mathrm{K}, \mathrm{W}$ e $\mathrm{Y}$ ), temos 5 que representam sons vocálicos (não consideramos nem o $\mathrm{Y}$, nem o $\mathrm{W}$, mesmo que, embora não ocorram substantivos comuns com essas letras, quando ocorrem em substantivos

\footnotetext{
${ }^{24}$ Fonte: (SEYMOUR, P. H. K.; ARO , M; ERSKINE, J. M., 2003, p. 146)
} 
próprios ocupam o lugar da vogal) e 18 consoantes (não consideramos o K, mesmo que, embora não ocorram substantivos comuns com essa letra, quando ocorrem em substantivos próprios ocupam o lugar da consoante).

As cinco letras que representam graficamente todos os sons vocálicos são responsáveis por corresponder a 8 fonemas vocálicos pretônicos, 7 fonemas vocálicos tônicos, 7 fonemas vocálicos postônicos em posição final, 5 ou 7 (a depender da região do país) fonemas vocálicos postônicos mediais e 5 vogais nasais. As vogais pretônicas e postônicas caracterizam a variação dialetal do português brasileiro, enquanto as tônicas consistem em um conjunto homogêneo em todas as variedades do português:

As vogais orais em português podem ser tônicas, pretônicas ou postônicas. Vogais tônicas carregam o acento primário. Como vimos anteriormente, o diacrítico ['] deve preceder a sílaba acentuada para marcar a tonicidade: ['la] "lá". Vogais pretônicas precedem a vogal tônica e vogais postônicas seguem a vogal tônica. Na palavra [abaka'Ji] "abacaxi" as vogais pretônicas são todas [a]. Vogais postônicas podem ser classificadas como postônica final ou postônica medial. Vogais postônicas finais nas palavras ['matü] "mato" e ['numerü] "número" têm o símbolo [u]. Vogais postônicas mediais - também chamadas de vogais postônicas não-finais - ocorrem em palavras proparoxítonas do português ocupando a posição vocálica que segue o acento tônico. As vogais postônicas mediais nas palavras ['arldu] "árido" e ['palldü] "pálido" têm o símbolo [I].(Silva, 2003, p. 78-79)

Tabela 6: Relação de vogais orais e nasais nas diferentes posições

\begin{tabular}{|c|c|c|c|c|}
\hline & Pretônica & Tônica & $\begin{array}{c}\text { Postônica } \\
\text { medial }\end{array}$ & Postônica final \\
\hline Vogais orais & $\mathrm{i}$ e $\varepsilon$ a $\mathrm{e} u$ o & $\mathrm{i}$ e $\varepsilon$ a $\mathrm{u}$ o 0 & i e $\varepsilon$ a o $\mathrm{u} \supset$ & $\begin{array}{c}\text { I (i) (e) } \mathrm{e}(\mathrm{a}) \mathrm{U} \\
\text { (o) }\end{array}$ \\
\hline Vogais nasais & & $\tilde{e} \tilde{a}$ & $\tilde{o} \tilde{U}$ & \\
\hline
\end{tabular}

As vogais tônicas orais são basicamente iguais em todos os dialetos do portuguêsbrasileiro e as variações ocorrem somente com um grupo restrito, no qual uma mesma palavra pode ser pronunciada com $[\varepsilon]$ ou com [e]. Exemplo:

Tabela 7: Exemplo de pronúncias para a vogal $\mathbf{E}$, de acordo com a variação dialetal do portugûes-brasileiro

\begin{tabular}{|l|l|l|}
\hline Palavra & Pronúncia 1 & Pronúncia 2 \\
\hline (ele foi) pego & ['pego] (pêgu) & ['pego] (pégu) \\
\hline Extra & ['estra] (êxtra) & ['estra] (éxtra) \\
\hline
\end{tabular}




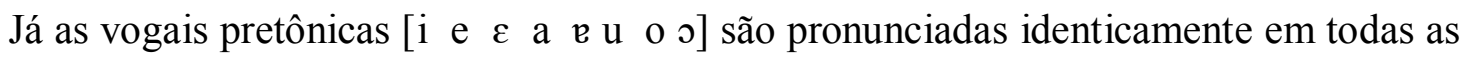
variações do português, ainda que haja variação dialetal entre os segmentos vocálicos $[\varepsilon$, o]$[\mathrm{e}, \mathrm{o}]-[\mathrm{i}, \mathrm{u}]$, todos em posição pretônica, para palavras como dedal (d[e]dal ou d[ع]dal), modelo (m[o]delo ou $\mathrm{m}[\mathrm{o}]$ delo).

As vogais postônicas finais são distintas das pretônicas e tônicas para a maioria dos falantes brasileiros e são pronunciadas como [I, e, v]; apenas em alguns dialetos as vogais [e] e [o] ocorrem em posição postônica final como em "jure" e "mato".

Por fim, as vogais postônicas mediais ocorrem entre a vogal tônica e a vogal átona final em palavras proparoxítonas. No português-brasileiro há grande variação de pronúncia das vogais postônicas mediais; na região Nordeste, por exemplo, as vogais $[\varepsilon$, o] ocorrem em posição postônica medial no estilo formal de fala, exemplo:

\section{Tabela 8: Exemplo de pronúncias para as vogais postônicas mediais [ $\boldsymbol{\varepsilon}, \boldsymbol{\jmath}]$}

\begin{tabular}{|l|l|l|}
\hline Palavra & Pronúncia 1 & Pronúncia 2 \\
\hline Número & Núm[e]ro (númêro) & Núm[c]ro (núméro) \\
\hline Pérola & Pér[o]la (pérôla) & Pér[o]la (péróla) \\
\hline
\end{tabular}

As vogais nasais são produzidas com um abaixamento do véu palatino produzindo uma qualidade vocal diferente, no entanto, a diferença é pequena e por isso mantém-se os sinais gráficos da representação oral correspondente desses sons, acrescidos apenas de um til ( $\sim)$ para marcar a nasalidade. Entre as nasais há uma divisão entre as vogais que são obrigatoriamente nasais em qualquer dialeto do português (como rã, anta, som, vento etc.) e aquelas nas quais a nasalidade é opcional e marca da variação dialetal, como relatado anteriormente, com o exemplo da palavra BANANA (e acrescido dos exemplos: fome, canavial, camareira etc.).

Já as dezoito letras que representam graficamente os sons consonânticos são responsáveis por corresponder a 23 fonemas, incluindo 19 consoantes prevocálicas e 4 consoantes posvocálicas. Assim como ocorre com as vogais, há uma vasta variedade em relação à realização das consoantes no português, tanto pelas posições em que ocupam na palavra, quanto pela localização geográfica onde são pronunciadas. Destacaremos três casos mais evidentes.

A realização da letra $\mathrm{R}$ muda se está no início, no meio ou no final das palavras, bem como em função de onde é produzida, como bem exemplifica a Tabela 9 (Silva, 2003, p. 51): 
Tabela 9: Realizações do r ou rr ortográfico possíveis em três regiões brasileiras

\begin{tabular}{|c|c|c|c|c|}
\hline & Exemplo & $\begin{array}{c}\text { Belo } \\
\text { Horizonte } \\
\end{array}$ & $\begin{array}{c}\text { Rio de } \\
\text { Janeiro } \\
\end{array}$ & Caipira \\
\hline Intervocálico & caro & {$[\Upsilon]$} & {$[r]$} & {$[\Upsilon]$} \\
\hline $\begin{array}{l}\text { Após consoante na mesma } \\
\text { sílaba }\end{array}$ & prato & {$[\varsigma]$} & {$[c]$} & {$[\mathrm{r}]$} \\
\hline Intervocálico & carro & {$[\mathrm{h}]$} & {$[\chi]$} & {$[\breve{r}]$} \\
\hline Início de palavra & rua & {$[\mathrm{h}]$} & {$[\chi]$} & {$[\breve{r}]$} \\
\hline $\begin{array}{l}\text { Após consoante em outra } \\
\text { sílaba }\end{array}$ & Israel & {$[\mathrm{h}]$} & {$[\chi]$} & {$[\breve{r}]$} \\
\hline Final de Palavra & mar & {$[\mathrm{h}]$} & {$[\chi]$} & {$[\mathrm{I}]$} \\
\hline $\begin{array}{l}\text { Final de sílaba antes de } \\
\text { consoante vozeada }\end{array}$ & gordo & [6] & [४] & {$[\mathrm{I}]$} \\
\hline $\begin{array}{l}\text { Final de sílaba antes de } \\
\text { consoante desvoz }\end{array}$ & torto & {$[\mathrm{h}]$} & {$[\chi]$} & {$[\mathrm{I}]$} \\
\hline
\end{tabular}

A letra $S$ também varia na forma em que ocorre em função da posição em que ocupa na palavra, pela letra que a segue e a região em que é produzida.

Tabela 10: Realizações do S possíveis em três regiões brasileiras

\begin{tabular}{cccccc} 
& Posição & \multicolumn{3}{c}{ Belo } & \multicolumn{2}{c}{ Rio de } & \\
& Exemplo & Horizonte & Janeiro & Recife \\
\hline \hline Antes de & meio de palavra & casca & {$[\mathrm{s}]$} & {$\left[\int\right]$} & {$[\mathrm{s}]$} \\
consoantes & final da palavra & paz & {$[\mathrm{s}]$} & {$\left[\int\right]$} & {$[\mathrm{s}]$} \\
desvozeada & final de sílaba seguido & & {$[\mathrm{s}]$} & {$\left[\int\right]$} & {$[S]$} \\
\hline $\begin{array}{c}\text { Antes de } \\
\text { ponsoantes }\end{array}$ & meio de palavra 1 & asma & {$[\mathrm{z}]$} & {$[3]$} & {$[\mathrm{z}]$} \\
Vozeada & final de sílaba seguido & & {$[\mathrm{z}]$} & {$[3]$} & {$[3]$} \\
\hline
\end{tabular}

Outro processo que ocorre em certos dialetos do português-brasileiro, principalmente na região Sudeste, é a palatalização de oclusivas alveolares ${ }^{25}$. Esse processo ocorre com os fonemas /t/ e /d/ seguidos da vogal I, na pronúncia de palavras como "dia", que se realizam como [dia] ou como [dzia] ou "tia", que se realizam como [tia] ou como [t $\left.\int i a\right]$. Vale ressaltar que o que provoca a palatalização é a consoante " $d$ " ou " $t$ " anteceder o som da vogal $\mathrm{I}$, ainda

\footnotetext{
25 "Oclusiva" é um termo da fonética para categorizar os fonemas segundo o modo de articulação, e "palatais e alveolares”, segundo o ponto (local) em que ocorre a articulação.
} 
que ortograficamente seja escrita com a letra E, por exemplo, na palavra TESOURO, que pode ser pronunciada como [tesouro] ou como [t $\mathrm{t}$ izouro]. Há ainda dialetos que usam a palatalização em alguns segmentos silábicos e em outros não, como em Curitiba, onde HEPATITE se pronuncia como [epa't $\left.\int \mathrm{it}\right]$.

Até o momento, vimos a enorme variedade de realizações sonoras, a quantidade de fonemas e as diferentes correspondências som-grafia das letras e dos fonemas no portuguêsbrasileiro. Contudo, outro aspecto que apresenta diversidade em sua ocorrência tem a ver com o nome que cada letra tem. O próprio Acordo Ortográfico de 1990 apresenta as letras e os respectivos nomes, mas reconhece a possibilidade de mais de uma forma de designação.

Tabela 11: Nomes das letras do português-brasileiro, a realização oficial e outras possibilidades

\begin{tabular}{|c|c|c|c|c|c|}
\hline Letra & $\begin{array}{c}\text { Conforme } \\
\text { acordo } \\
\text { ortográfico }\end{array}$ & $\begin{array}{c}\text { Outras } \\
\text { realizações } \\
\text { encontradas }\end{array}$ & Letra & $\begin{array}{c}\text { Conforme } \\
\text { acordo } \\
\text { ortográfico }\end{array}$ & $\begin{array}{l}\text { Outras } \\
\text { realizações } \\
\text { encontradas }\end{array}$ \\
\hline A, a & Á & $\mathrm{a}$ & $\mathrm{N}, \mathrm{n}$ & Ene & Nê \\
\hline $\mathrm{B}, \mathrm{b}$ & Bê & bê & $\mathrm{O}, \mathrm{o}$ & $\hat{\mathrm{O}}$ & Ó \\
\hline $\mathrm{C}, \mathrm{c}$ & Cê & cê & $\mathrm{P}, \mathrm{p}$ & Pê & Pê \\
\hline $\mathrm{D}, \mathrm{d}$ & Dê & dê & $\mathrm{Q}, \mathrm{q}$ & quê & Quê \\
\hline $\mathrm{E}, \mathrm{e}$ & $\hat{\mathrm{E}}$ & é & $\mathrm{R}, \mathrm{r}$ & érre & Rê \\
\hline $\mathrm{F}, \mathrm{f}$ & Éfe & fê & $\mathrm{S}, \mathrm{s}$ & ésse & Sí \\
\hline $\mathrm{G}, \mathrm{g}$ & Gê & guê & $\mathrm{T}, \mathrm{t}$ & Tê & Tê \\
\hline $\mathrm{H}, \mathrm{h}$ & Agá & agá & $\mathrm{U}, \mathrm{u}$ & Ú & Ú \\
\hline $\mathrm{I}, \mathrm{i}$ & Í & Í & $\mathrm{V}, \mathrm{v}$ & Vê & Vê \\
\hline $\mathrm{J}, \mathrm{j}$ & Jóta & $\mathrm{ji}$ & $\mathrm{W}, \mathrm{w}$ & dábliu & Dábliu \\
\hline $\mathrm{K}, \mathrm{k}$ & Cá & $\mathrm{ca}$ & $X, x$ & $\mathrm{xis}$ & $\mathrm{X}$ is \\
\hline $\mathrm{L}, 1$ & Éle & lê & $\mathrm{Y}, \mathrm{y}$ & ípsilon & Pissilone \\
\hline $\mathrm{M}, \mathrm{m}$ & Eme & mê & $\mathrm{Z}, \mathrm{z}$ & Zê & Zê \\
\hline
\end{tabular}

Como é possível observar na Tabela 11Erro! Fonte de referência não encontrada., há uma nomeação oficial e outras possibilidades de ocorrência, muito frequentes na região Norte e Nordeste.

A depender da região, há algumas letras cujo nome coincide com um contexto silábico plausível - o que chamamos, nesse trabalho, de motivação fonológica. Por exemplo, a letra B, 
que não possui variação em sua nomeação, se chama "bê" e soa tal como o nome da letra no contexto da palavra BECO.

No entanto, quando da escrita da palavra ELEFANTE, a primeira sílaba "E" poderia ser considerada motivada fonologicamente somente nas regiões em que a nomeação das letras segue o Acordo Ortográfico.

O mesmo ocorre para a palavra MESA, segundo a nomeação da letra M pelo Acordo Ortográfico, para algumas regiões não haveria coincidência entre o nome da letra e a respectiva sílaba em que aparece (ME), mas em outras regiões a letra é nomeada por “mê”, coincidindo o nome da letra e o contexto silábico na palavra "mesa". No entanto, na palavra MECA [meka], por exemplo, apesar de ser ortograficamente representada pelas mesmas letras M e E, a pronúncia não coincide com o "mê" referente ao nome da letra, logo, nessas regiões, a sílaba ME pode ser motivada fonologicamente ou não, a depender da acentuação da vogal E. O mesmo vale para todas as demais consoantes.

Como vimos, o sistema vocálico brasileiro é bastante rico em possibilidades e, portanto, a motivação fonológica da sílaba representa um contexto bastante restrito frente à multiplicidade de realizações.

Vale destacar que o estado em que foi realizada a presente pesquisa utiliza a nomeação apresentada pelo Acordo Ortográfico.

Conforme foi apresentado até este momento, nota-se que na Língua Portuguesa não são muitos os fonemas que se realizam acusticamente na língua falada e que podem ser representados de maneira direta e unívoca por grafemas, pois a mesma letra pode representar diferentes fonemas (como a letra $\mathrm{S}$ representa os fonemas [J], [ks], [s] e [z]), assim como várias letras podem representar um mesmo fonema (como as letras J e G representam o fonema [3]). Além disso, mesmo quando uma letra consoante é transparente, como o B, por exemplo, que representa somente o fonema $[\mathrm{b}]$, se estiver associada à letra $\mathrm{E}$, o contexto silábico por elas formado só coincidirá com a respectiva emissão sonora se a letra "E" estiver representando o fonema [e], e essa situação - de coincidência do contexto silábico com a emissão sonora dessa parte da palavra - ocorrerá exclusivamente se essa pronúncia for realizada nas localidades em que a letra E é designada pelo fonema [e] e não pelo fonema $[\varepsilon]$ e nas palavras em que haja essa coincidência.

A escrita da sílaba inicial da palavra BECO, por exemplo, poderá ser considerada mais transparente e motivada fonologicamente (coincidência entre contexto silábico e a emissão sonora). No entanto, na realização sonora da palavra BELO, apesar de a sílaba ser formada por 
$\mathrm{B}+\mathrm{E}$, a vogal se realiza como $[\varepsilon]$, formando oralmente a sílaba $[\mathrm{b} \varepsilon]$, que não coincide com o nome da letra B [be].

Nessa parte do trabalho buscamos trazer para a discussão alguns elementos de caracterização do português que evidenciassem sua complexidade e suas inúmeras possibilidades de relação entre fonemas e grafemas, pois, ainda que seja considerada uma língua transparente, toda essa multiplicidade certamente impõe muitos desafios no momento de ler e escrever para aqueles que ainda não dominam o sistema de escrita. Conhecer as transparências e também as opacidades do sistema ortográfico português é essencial para saber e controlar quais desafios se está propondo a uma criança, seja no momento de aprendizagem, seja no momento de investigação, em que suas produções serão analisadas como reflexo do processo de aprendizagem.

Conhecer as características do idioma e do dialeto utilizado pelos sujeitos da amostra é fundamental para a escolha das palavras e, sobretudo, para a análise que da produção decorre. 


\section{CAPÍTULO 2. PROBLEMA DE INVESTIGAÇÃO E METODOLÓGICO}

A presente pesquisa teve como objetivo averiguar qual efeito o conhecimento do nome das letras teve sobre as crianças brasileiras pré-alfabéticas ao tomarem decisões gráficas no momento de escrever palavras ou completar palavras já escritas.

Em estudos anteriores, Pollo et al. (2015); Read e Treiman (2013); Treiman (1994, 1998); Treiman et al. (2001) vêm insistindo que o conhecimento das letras poderia ser considerado como um elemento fundamental para começar o processo de alfabetização. No entanto, em suas pesquisas, ainda que realizadas com crianças falantes do português-brasileiro, há diversos aspectos metodológicos questionáveis. Não é explicitado quais letras as crianças reconhecem e a partir de qual nomenclatura, uma vez que sabemos que há mais de uma forma de nomeação; o ditado de palavras realizado é feito de maneira coletiva, não controlando as justificativas dadas pelas crianças às suas produções; e não é considerada a escolha das palavras a serem escritas pelas crianças, nem do ponto de vista das características do idioma - a complexidade que determinada escrita representará -, nem do ponto de vista dos sujeitos e suas possibilidades de conceitualização sobre a escrita, propondo palavras que, partindo da perspectiva a qual desejam refutar, gerariam conflitos cognitivos importantes e que seriam refletidos na produção. Outro aspecto bastante discutível nos estudos apresentados é que, embora defendam que conhecer o nome da letra seja a primeira entrada ao som que a letra vai representar e que esse conhecimento é condição para que as crianças se alfabetizem, não justificam o fato de que muitas crianças demonstram conhecer as letras por seus nomes e os respectivos sons, mas não leem nem escrevem convencionalmente.

Ao contrário dessa visão, a partir de uma perspectiva psicogenética do desenvolvimento, insistimos em mostrar que a alfabetização não é um problema de ensino ou de exposição à informação, senão, sobretudo, de representação, e que a informação que as crianças obtêm não é igualmente útil para todos, mas sim útil em função dos sistemas de representação que elas constroem ao redor da informação dada (Ferreiro, 1997). Ou seja, em diferentes momentos conceituais as crianças enfrentam de maneira diferente o problema de escrever ou completar uma palavra escrita, e a informação que elas têm sobre o sistema de escrita (nome e som da letra) será utilizada de acordo com as possibilidades de análise e reflexão sobre o escrito, e, assim, quanto mais avançado for o nível conceitual da criança, mais proveito ela poderá tirar 
da informação. Portanto, quanto maior o nível de compreensão do sistema de escrita, melhor o uso da informação relacionada ao uso e à função das letras (Quinteros, 1997).

Acreditamos que a motivação fonológica das letras (coincidência entre o nome da letra e o contexto silábico) e o conhecimento do nome delas podem ser úteis para crianças que já perceberam a relação entre a pauta sonora e a pauta gráfica, mas não serão úteis para aquelas que ainda não compreenderam a relação - crianças silábicas sem valor sonoro convencional - e para aquelas que já se deram conta de que uma letra apenas não é suficiente para representar as sílabas - crianças silábica-alfabéticas - já que a estrutura CV é considerada a sílaba canônica no português, uma vez que representa metade dos dados, $64 \%$, sendo a mais frequente ${ }^{26}$. Também acreditamos que a possibilidade de identificação do nome da letra será favorecida pela interação da criança com a linguagem escrita - saber que a letra “'O’ é a da Olívia”, por exemplo.

No entanto, há uma carência de investigações sobre como ocorre a construção do conhecimento por parte das crianças que corroborem com essa hipótese e refutem a proposição da existência dos pré-requisitos para a alfabetização.

Nesse sentido, este trabalho busca levantar o conhecimento que as crianças préalfabéticas têm sobre o nome das letras e responder as seguintes perguntas: conhecer os nomes das letras pode facilitar para que as crianças utilizem pertinentemente tais letras para escrever palavras? Conhecer o nome das letras facilita-lhes identificar a letra inicial de uma palavra dada? O momento conceitual (nível de escrita) condiciona a utilidade do conhecimento do nome da letra ao escrever ou completar palavras?

Os objetivos deste trabalho são, portanto, investigar se o nível de escrita tem relação direta com as tarefas de escrita de palavras, de completar palavras e de identificação de letras fora de contexto, se a motivação fonológica das letras tem algum efeito nessas tarefas e se a identificação de letras fora do contexto se relaciona com a possibilidade de escrever uma palavra escrita ou completá-la. As hipóteses que nortearam o trabalho foram as seguintes:

a. O nível de conceitualização sobre o sistema de escrita apresentado pelas crianças (préalfabéticas) determina sua possibilidade de identificar as letras por seu nome fora do contexto de leitura e de escrita e para utilizá-las ao escrever ou ao completar palavras. Ou seja, quanto maior o nível de escrita, maior sua possibilidade de identificar letras, de escrever e completar palavras.

${ }^{26}$ (Marques, 2008) 
À diferença do que sustenta a teoria cognitiva, acreditamos que as crianças em processo de alfabetização podem escrever e completar palavras apoiando-se em informações contextuais ou linguísticas e não somente após completar o treinamento de identificação de letras.

Para verificar essa hipótese, o nível de escrita ou nível de conceitualização sobre o sistema de escrita é a variável independente, e os valores considerados para o estudo são, em escala ordinal, do menor para o maior:

1. Escritas silábicas sem valor sonoro convencional;

2. Escritas silábicas com valor sonoro convencional;

3. Escritas silábico-alfabéticas.

Já as variáveis dependentes são: (1) a identificação de letras fora de um contexto de leitura ou escrita; (2) escrever palavras, considerando exclusivamente a representação escrita da sílaba inicial de uma palavra ditada; (3) identificação da letra inicial que completa uma dada palavra escrita.

Os valores considerados das variáveis dependentes para o estudo são:

Tabela 12: Valores considerados das variáveis dependentes para a hipótese 1: o nível de conceitualização da escrita determina as possibilidades de identificar letras, escrever e completar palavras

\begin{tabular}{lllll}
\hline $\begin{array}{l}\text { Identificar a letra por seu } \\
\text { nome }\end{array}$ & $\begin{array}{l}\text { Representação escrita da } \\
\text { sílaba inicial de uma } \\
\text { palavra ditada }\end{array}$ & $\begin{array}{l}\text { Identificação da letra } \\
\text { inicial que completa uma } \\
\text { palavra escrita dada }\end{array}$ \\
\hline Identifica o nome das letras & $\begin{array}{l}\text { Escrita convencional da } \\
\text { apresentada }\end{array}$ & sílaba & & pertinentemente
\end{tabular}

Não identifica o nome das Escrita silábica pertinente Não identifica a letra inicial letras que apresentada da sílaba usando a consoante pertinentemente envolvida no segmento

Escrita silábica pertinente da sílaba usando a vogal envolvida no segmento Escritas não pertinentes 
Pelo número de variáveis dependentes envolvidas nesta primeira hipótese, pudemos distinguir as seguintes sub-hipóteses:

- Conforme aumenta o nível de conceitualização sobre o sistema de escrita, aumenta a possibilidade de reconhecer o nome das letras apresentadas;

- Conforme aumenta o nível de conceitualização sobre o sistema de escrita, aumenta a possibilidade de escrever pertinentemente o segmento silábico inicial de uma palavra ditada;

- Conforme aumenta o nível de conceitualização sobre o sistema de escrita, aumenta a possibilidade de identificar a letra inicial que completa a escrita de uma dada palavra.

b. A segunda hipótese deste estudo propõe que conhecer o nome das letras pode facilitar que as crianças utilizem pertinentemente tais letras para escrever palavras (representar o segmento silábico inicial de uma palavra ditada).

Para averiguar essa hipótese, conhecer o nome das letras, diferenciando o "nome motivado" das letras ("TE", "PE", "VE", "BE", por exemplo) dos nomes "não motivados", (“ÉSSE”, “ÉRRE”, "ÉLE”, “EME”, por exemplo) é a variável independente. Os valores considerados da variável independente para o estudo são:

Tabela 13: Valores considerados da variável independente para a hipótese 2: conhecer os nomes das letras pode facilitar a utilização pertinente da mesma no contexto de escrita

\begin{tabular}{cc}
$\begin{array}{c}\text { Reconhecer letras com nomes } \\
\text { motivados }\end{array}$ & $\begin{array}{c}\text { Reconhece letras com nomes não } \\
\text { motivados }\end{array}$ \\
\hline Reconhece & Reconhece \\
\hline Não reconhece & Não reconhece \\
\hline
\end{tabular}

Já a variável dependente é a representação escrita que as crianças fazem do segmento silábico inicial das palavras ditadas; e os valores considerados dessa variável são:

- Representa convencionalmente o segmento silábico inicial da palavra;

- Representa silabicamente o segmento inicial empregando uma consoante pertinente;

- Representa silabicamente o segmento inicial empregando uma vogal pertinente;

- Representa silabicamente o segmento inicial empregando uma grafia não pertinente.

Desta segunda hipótese derivam três hipóteses mais específicas:

- O reconhecimento das letras com nomes motivados será mais útil para representar segmentos silábicos iniciais que correspondam ao nome da letra e, consequentemente, 
- O reconhecimento das letras com nomes motivados será menos útil para representar segmentos silábicos iniciais que não correspondam ao nome da letra;

- O reconhecimento das letras com nomes não motivados poderia ser útil para representar segmentos silábicos iniciais que envolvam o fonema representado pela respectiva letra.

c. Conhecer o nome das letras facilita que as crianças identifiquem a letra inicial que completa a escrita de uma dada palavra.

Para essa terceira hipótese a variável independente é a mesma descrita na hipótese anterior - conhecer os nomes das letras.

A variável dependente, portanto, é a identificação da letra inicial para completar a escrita de uma dada palavra, e os valores que essa variável pode ter são:

- Identifica a letra inicial que completa uma dada palavra escrita;

- Não identifica a letra inicial que completa uma dada palavra escrita.

Desta terceira hipótese derivam três mais específicas:

- Reconhecer uma letra com nome motivado será mais útil para identificar a letra inicial que completa uma palavra cuja sílaba inicial corresponde ao nome dessa letra;

- Reconhecer uma letra com nome motivado será menos útil para identificar a letra inicial que completa uma palavra cuja sílaba inicial não corresponde ao nome dessa letra;

- Reconhecer uma letra com nome não motivado poderia ser útil para identificar a letra inicial que completa uma palavra cuja sílaba inicial envolve o fonema representado pela respectiva letra.

d. O nível de escrita determina a utilidade que o conhecimento do nome da letra representa ao escrever ou completar palavras escritas.

Essa hipótese envolve todas as outras anteriores e é a hipótese que justifica o nosso estudo.

\subsection{Descrição das tarefas}

O presente estudo envolveu três tarefas, que constituíram as situações experimentais centrais para obtenção dos dados da amostra.

a. Tarefa de escrita de substantivos: A tarefa de escrita teve dois objetivos. Primeiro, o de conhecer o nível de conceitualização da língua escrita em que se encontravam as crianças da 
amostra de acordo com os parâmetros descritos por Ferreiro e Teberosky (1999); segundo, observar como as crianças utilizam o conhecimento que têm sobre os nomes das letras em tarefas de escrita e se há coincidência entre o contexto silábico e o nome da letra, ou seja, se a motivação fonológica é uma informação relevante no momento de escrever.

Foram ditados doze substantivos trissilábicos compostos pela estrutura silábica regular do português (CV-CV) e extraídos do dicionário "Mini Aurélio escolar".

O critério para determinar o nível de conceitualização das crianças sobre o sistema de escrita baseou-se no apresentado por Fernández (2015) - foi de tipo estatístico, em função da porcentagem da presença de segmentos pertinentes empregados para formar a sílaba, unidade intrassilábica ou fonema, de acordo com cada caso.

Por isso, consideramos que uma criança apresentava escrita silábica quando representou a sílaba com apenas uma letra em $75 \%$ dos segmentos que compunham as palavras apresentadas. No total das palavras apresentadas, existem 36 sílabas (12 substantivos x 3 sílabas por substantivo), portanto, $75 \%$ corresponde a ter escrito uma letra por sílaba em, pelo menos, 26 segmentos.

O critério para formar os grupos silábicos sem valor sonoro convencional e silábico com valor sonoro convencional (SSVSC e SCVSC, respectivamente) foi a pertinência das letras utilizadas para representar cada segmento.

As crianças agrupadas em SSVSC foram aquelas que representaram uma sílaba com uma consoante ou vogal - que não formava parte desta - em pelo menos $75 \%$ dos casos. $\mathrm{Ou}$ seja, 26 ou mais sílabas, do total de 36 , foram representadas por letras que não faziam parte da sílaba em questão. Exemplo de escrita SSVSC: 


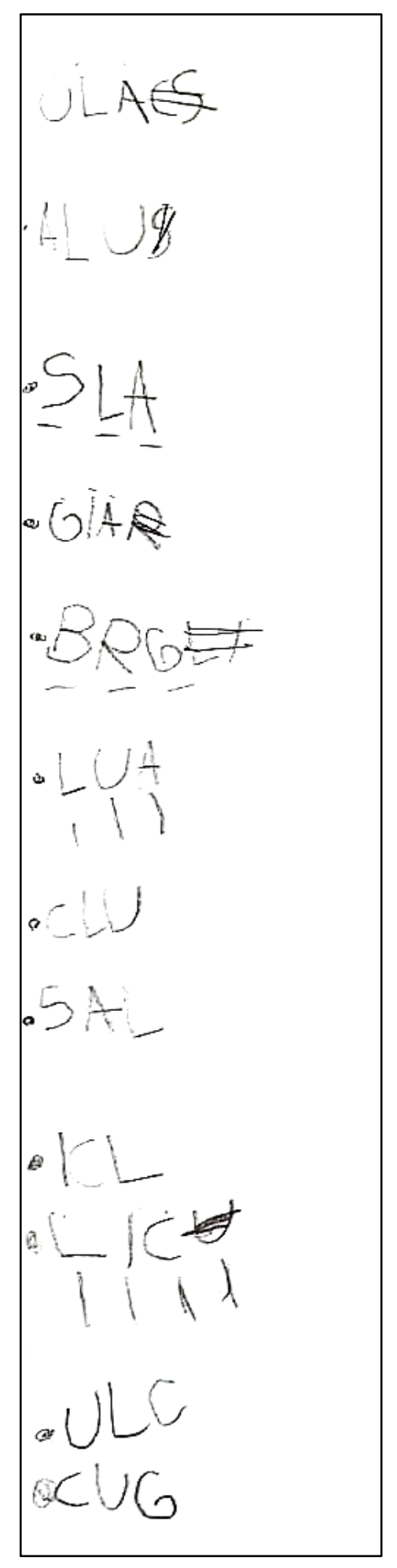

Figura 1 Exemplo de escrita silábica sem valor convencional

\begin{tabular}{ccc}
\hline $\mathrm{U}$ & $\mathrm{L}$ & $\mathrm{A}(\mathrm{CS})$ \\
te & $\mathbf{m i}$ & $\mathbf{D a}$ \\
\hline $\mathrm{A}$ & $\mathrm{L}$ & $\mathrm{U}(\mathrm{S})$ \\
ra & $\mathbf{p i}$ & $\mathbf{N a}$ \\
\hline $\mathrm{S}$ & $\mathrm{L}$ & $\mathrm{A}$ \\
to & $\mathbf{m a}$ & $\mathbf{D a}$ \\
\hline $\mathrm{G}$ & $\mathrm{I}$ & $\mathrm{A}(\mathrm{R})$ \\
$\mathbf{p e}$ & $\mathbf{l u}$ & $\mathbf{D a}$ \\
\hline $\mathrm{B}$ & $\mathrm{R}$ & $\mathrm{G}(\mathrm{ET})$ \\
no & $\mathbf{v e}$ & $\mathbf{N a}$ \\
\hline $\mathrm{L}$ & $\mathrm{U}$ & $\mathrm{A}$ \\
$\mathbf{p a}$ & $\mathbf{l e}$ & $\mathbf{T a}$ \\
\hline $\mathrm{C}$ & $\mathrm{L}$ & $\mathrm{U}$ \\
$\mathbf{v e}$ & $\mathbf{r i}$ & $\mathbf{N a}$ \\
\hline $\mathrm{S}$ & $\mathrm{A}$ & $\mathrm{L}$ \\
$\mathbf{m u}$ & $\mathbf{l e}$ & $\mathbf{T a}$ \\
\hline $\mathrm{I}$ & $\mathrm{C}$ & $\mathrm{L}$ \\
$\mathbf{v i}$ & $\mathbf{b o}$ & $\mathbf{R a}$ \\
\hline $\mathrm{L}$ & $\mathrm{I}$ & $\mathrm{C}(\mathrm{U})$ \\
$\mathbf{b e}$ & $\mathbf{x i}$ & $\mathbf{G a}$ \\
\hline $\mathrm{U}$ & $\mathrm{L}$ & $\mathrm{C}$ \\
lu & $\mathbf{n e}$ & $\mathbf{T a}$ \\
\hline $\mathrm{C}$ & $\mathrm{U}$ & $\mathrm{G}$ \\
$\mathbf{b u}$ & $\mathbf{z i}$ & $\mathbf{N a}$ \\
\hline & & \\
\hline
\end{tabular}

Figura 2 Quadro que apresenta cada sílaba das referidas palavras em uma célula e as letras utilizadas para a escrita de cada sílaba. 
A escrita da Figura 1 segue uma lógica silábica, porque cada letra se refere a um segmento silábico oral. As palavras foram justificadas, como se apresenta no quadro da Figura 2.

Na parte superior da linha é apresentada, em maiúscula, a forma como a criança escreveu a sílaba e, imediatamente embaixo, em letra minúscula e negritada, o que disse ao ler a palavra que escreveu. No caso da palavra TEMIDA, a criança escreveu ULACS. Em seguida, leu assinalando com o dedo indicador: para U, leu TE; para L, leu MI; para A, leu DA. Se deu conta de que havia letras a mais (CS) e as riscou. Leu novamente para confirmar "se havia ficado tudo certo" e leu novamente atribuindo a cada letra uma sílaba, oralmente.

Vale destacar que a criança, cuja escrita foi apresentada na Figura 1, chama-se LUCAS, e observamos em suas produções a predominância das letras do seu nome em apresentação variada.

Concluímos que se tratava de uma escrita silábica sem valor sonoro convencional, porque, apesar das justificativas serem predominantemente silábicas, menos de $75 \%$ dos elementos gráficos empregados compunham a sílaba convencionalmente.

As crianças agrupadas em SCVSC utilizaram uma grafia pertinente (vogal ou consoante) para escrever as sílabas em pelo menos 75\% das vezes. Ou seja, 26 ou mais sílabas, do total de 36, foram representadas por letras que faziam parte da sílaba em questão. Exemplo de escrita SCVSC: 


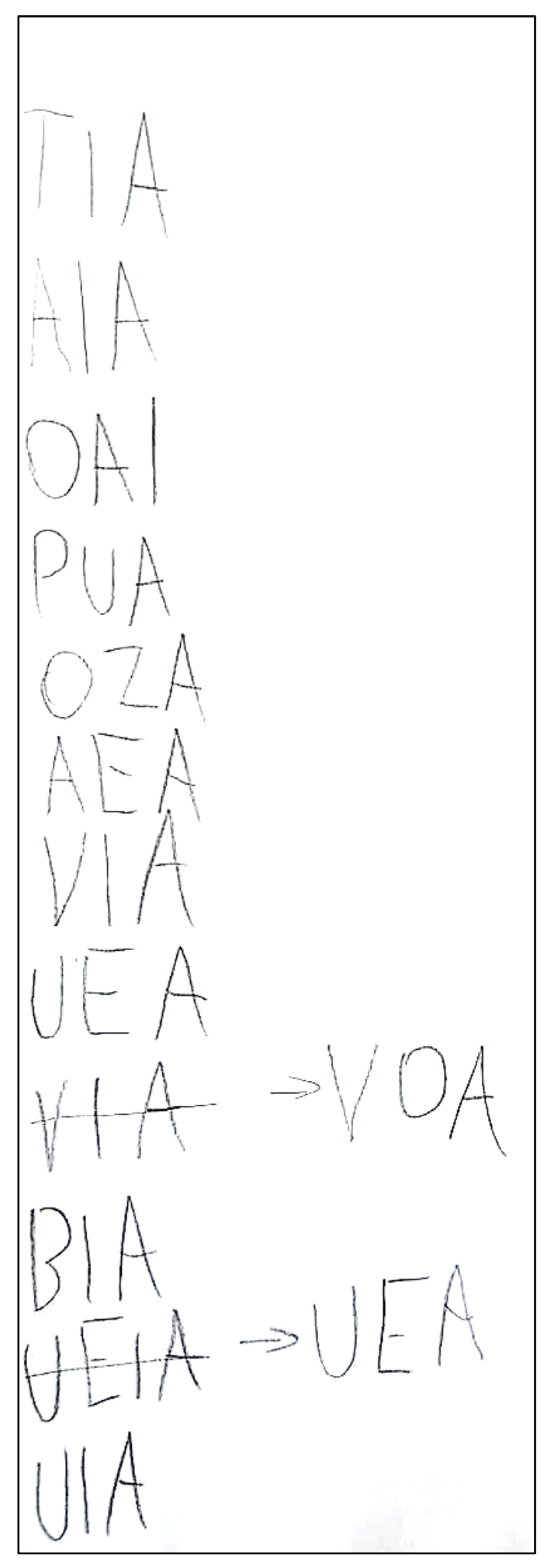

Figura 3 Exemplo de escrita silábica com valor convencional

\begin{tabular}{|c|c|c|}
\hline $\mathrm{T}$ & I & $\mathrm{A}$ \\
\hline te & mi & Da \\
\hline A & I & A \\
\hline $\mathbf{r a}$ & pi & $\mathbf{N a}$ \\
\hline $\mathrm{O}$ & A & $\mathrm{I}$ \\
\hline to & ma & da \\
\hline $\mathrm{P}$ & $\mathrm{U}$ & $\mathrm{A}$ \\
\hline pe & lu & da \\
\hline $\mathrm{O}$ & $\mathrm{Z}$ & $\mathrm{A}$ \\
\hline no & ve & na \\
\hline A & $\mathrm{E}$ & A \\
\hline pa & le & ta \\
\hline $\mathrm{V}$ & I & $\mathrm{A}$ \\
\hline ve & ri & na \\
\hline $\mathrm{U}$ & $\mathrm{E}$ & $\mathrm{A}$ \\
\hline mu & le & ta \\
\hline I & $\mathrm{O}$ & $\mathrm{A}$ \\
\hline vi & bo & ra \\
\hline B & I & $\mathrm{A}$ \\
\hline be & $\mathbf{x i}$ & ga \\
\hline $\mathrm{U}$ & $\mathrm{E}$ & $\mathrm{A}$ \\
\hline lu & ne & ta \\
\hline $\mathrm{U}$ & I & A \\
\hline bu & $\mathbf{z i}$ & na \\
\hline
\end{tabular}

Figura 4 Quadro que apresenta cada sílaba das referidas palavras em uma célula e as letras utilizadas para a escrita de cada sílaba 
A escrita da Figura 3 segue uma lógica silábica, porque cada letra se refere a um segmento silábico oral e, diferentemente da escrita anterior, cada sílaba foi representada por uma vogal ou consoante que faz parte do segmento silábico convencional. As palavras foram justificadas como se apresenta no quadro da Figura 4.

As crianças reunidas no grupo dos silábico-alfabéticos (SA) utilizaram escritas que mostravam a possibilidade de análise intrassilábica, evidenciada pelo uso de mais de uma grafia para representar pelo menos $50 \%$ dos segmentos silábicos. Ou seja, 18 ou mais sílabas, do total de 36 , foram representadas por mais de uma grafia que formava parte da sílaba, como se apresenta a seguir: 


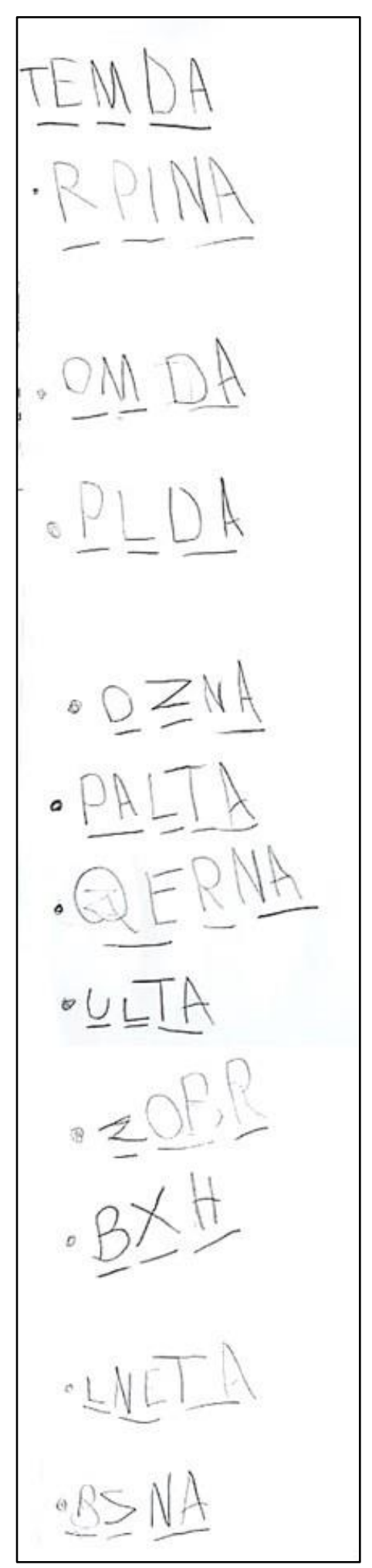

Figura 5 Exemplo de escrita silábica alfabética

\begin{tabular}{|c|c|c|}
\hline $\begin{array}{l}\mathrm{TE} \\
\text { te }\end{array}$ & $\begin{array}{l}\mathrm{M} \\
\mathbf{m i}\end{array}$ & $\begin{array}{l}\mathrm{DA} \\
\text { Da }\end{array}$ \\
\hline $\mathrm{R}$ & PI & NA \\
\hline $\mathbf{r a}$ & pi & $\mathbf{N a}$ \\
\hline $\mathrm{O}$ & MA & DA \\
\hline to & ma & da \\
\hline $\mathrm{P}$ & $\mathrm{L}$ & $\mathrm{DA}$ \\
\hline pe & lu & da \\
\hline $\mathrm{O}$ & $\mathrm{Z}$ & $\mathrm{NA}$ \\
\hline no & ve & na \\
\hline $\mathrm{PA}$ & $\mathrm{L}$ & TA \\
\hline pa & le & ta \\
\hline $\mathrm{QE}$ & $\mathrm{R}$ & NA \\
\hline ve & ri & na \\
\hline $\mathrm{U}$ & $\mathrm{L}$ & TA \\
\hline mu & le & ta \\
\hline$Z$ & OB & $\mathrm{R}$ \\
\hline vi & bo & ra \\
\hline B & $\mathrm{X}$ & $\mathrm{H}$ \\
\hline be & $\mathbf{x i}$ & ga \\
\hline LU & $\mathrm{NE}$ & TA \\
\hline lu & ne & ta \\
\hline $\mathrm{BU}$ & $\mathrm{Z}$ & NA \\
\hline bu & $\mathbf{z i}$ & na \\
\hline
\end{tabular}

Figura 6 Quadro que apresenta cada sílaba das referidas palavras em uma célula e as letras utilizadas para a escrita de cada sílaba. 
A escrita da Figura 5 segue uma lógica silábica-alfabética, já que 50\% das sílabas foram escritas de maneira convencional, composta, portanto, da respectiva consoante e vogal. As palavras foram justificadas como se apresenta no quadro da Figura 6.

Nessa tarefa considerou-se tanto as produções escritas como as justificativas representadas pelas leituras realizadas. Além de evidenciar as conceitualizações de cada criança sobre o sistema de escrita, essa tarefa foi fundamental para relacionarmos a influência destas na identificação de letras fora de contexto e de completar palavras, bem como para analisarmos a relação entre o nível de escrita e a motivação fonológica das letras.

\section{Seleção das palavras}

Além de determinar o nível de escrita em que se encontram as crianças da amostra, segundo os parâmetros descritos por Ferreiro e Teberosky (1999) - pré-silábico, silábico, silábico sem valor sonoro, silábico com valor sonoro, silábico-alfabético e alfabético - para poder selecionar a amostra, essa tarefa teve o objetivo de observar como as crianças utilizam o conhecimento que têm sobre os nomes das letras em atividades de escrita, e se a coincidência entre o contexto silábico e o nome da letra - motivação fonológica - é uma informação relevante no momento da escrita.

Por essa razão, as palavras selecionadas foram organizadas em três grupos de quatro palavras, cujas sílabas iniciais seguiam os seguintes critérios:

a. Palavras com sílabas iniciais motivadas: palavras cujas primeiras sílabas apresentam coincidência total do nome da consoante com o contexto silábico, ou seja, que são motivadas fonologicamente. Por exemplo, na palavra "TEMIDA" a letra "T" se chama "Tê" e coincide com o som formado pela sílaba $\mathrm{T}+\mathrm{E}$;

b. Palavras com sílabas iniciais de contraste: palavras em que as primeiras sílabas eram formadas pelas mesmas consoantes motivadas utilizadas no grupo de palavras anterior, mas em contexto silábico diferente de "Consoante motivada + E", para que a sílaba não fosse motivada e servisse para contrastarmos com o primeiro grupo de palavras. Por exemplo, na palavra "TOMADA", a sílaba TO é formada pela letra "T", que, dependendo do núcleo silábico, pode formar uma sílaba motivada $(\mathrm{T}+\mathrm{E})$ ou uma sílaba sem motivação $(\mathrm{T}+\mathrm{A} / \mathrm{I} / \mathrm{O} / \mathrm{U})$. Como aqui utilizaremos esse grupo para comparação, o chamamos de "contraste"; 
c. Palavras com sílabas iniciais não motivadas: palavras em que as primeiras sílabas eram compostas por letras que, independentemente do núcleo silábico, não têm motivação fonológica: o nome da letra não remete a nenhum som que esta produz isoladamente ou em contexto silábico.

Segundo estudo desenvolvido por Marques (2008), o português é uma língua predominantemente trissilábica, pois a maioria de suas unidades lexicais é composta por três sílabas $(38,82 \%$ - 1940 ocorrências), seguidas por palavras formadas por duas sílabas e quadrissílabos, respectivamente, e bem poucos monossílabos (2,06\%). Esse estudo também corrobora a hipótese de que a estrutura silábica canônica é a CV (sílaba formada por uma consoante + uma vogal), que representa mais da metade dos casos (64\%), sendo a mais recorrente: "essa estrutura é a base da fala, já que além de mais frequente é a que melhor se adequa ao ciclo de abertura e fechamento da mandíbula" (Marques, 2008, p. 95). Por essa razão, escolhemos realizar essa tarefa apenas com palavras trissílabas, formadas por sílabas simples (CV).

Para a seleção das palavras foram elaboradas duas listas: uma com as letras mais motivadas fonologicamente, ou seja, letras cujos nomes pudessem coincidir com uma sílaba plausível; e outra com as letras menos motivadas. Em seguida, essas letras foram distribuídas de forma decrescente de acordo com a frequência de sua aparição no português-brasileiro, levantada por Quaresma e Pinho (2007):

Tabela 14: Porcentagem de ocorrência de uso das letras no português-brasileiro, de acordo com sua motivação fonológica

\begin{tabular}{cccc}
\hline Letras mais motivadas & \multicolumn{3}{c}{ Letras menos motivadas } \\
\hline $\mathrm{D}$ & 5,09 & $\mathrm{~S}$ & 7,92 \\
$\mathrm{~T}$ & 4,17 & $\mathrm{R}$ & 6,74 \\
$\mathrm{C}$ & 3,24 & $\mathrm{~N}$ & 4,91 \\
$\mathrm{P}$ & 2,43 & $\mathrm{M}$ & 4,67 \\
$\mathrm{~V}$ & 1,71 & $\mathrm{~L}$ & 3,06 \\
$\mathrm{G}$ & 1,23 & $\mathrm{H}$ & 1,46 \\
$\mathrm{Q}$ & 1,21 & $\mathrm{~F}$ & 0,98 \\
$\mathrm{~B}$ & 1,05 & $\mathrm{~J}$ & 0,37 \\
$\mathrm{Z}$ & 0,47 & $\mathrm{X}$ & 0,22 \\
\hline
\end{tabular}

A partir de um dicionário escolar listamos todas as palavras trissílabas, por serem estas a extensão mais frequente do português e para que as crianças tivessem menos segmentos com 
os quais lidar, fazendo com que o contexto da palavra fosse o mais reduzido possível. Além disso, escolhemos palavras trissílabas porque a tarefa visava selecionar uma amostra de crianças cujas escritas não fossem alfabéticas, logo, crianças pouco experientes em relação à escrita, e não queríamos que sustentar a produção de uma palavra extensa fosse uma variável a ser considerada. Também descartamos as palavras dissílabas, pois, para as crianças silábicas, esta escrita representaria um conflito cognitivo, como apontado por Ferreiro e Teberosky (1999). Nesse momento conceitual a criança tem como hipótese que cada segmento sonoro observado é representado por um caractere gráfico; no entanto, a escrita de palavras com apenas duas sílabas geraria escritas com apenas dois caracteres, o que a colocaria em conflito com uma hipótese anterior, que é a da quantidade mínima de letras para ser considerada uma palavra escrita, pois, em geral, as crianças consideram-na a partir de três letras. Outro critério que também foi considerado no momento da escolha das palavras foi o de variabilidade entre as sílabas que as compunham, pois outra hipótese infantil é a de que para que esteja algo escrito é necessário que haja variação entre os caracteres, isto é, eles não podem se repetir. Por isso, todas as palavras foram compostas por sílabas contíguas diferentes.

Foram listadas somente as trissílabas formadas por sílabas simples, cuja estrutura é a mais recorrente no português-brasileiro: $\mathrm{CV}-\mathrm{CV}-\mathrm{CV}$, que não fossem compostas por sílabas repetidas.

Desta lista, selecionamos as palavras iniciadas pelas letras mais motivadas (D, T, C, P, $\mathrm{V}, \mathrm{G}, \mathrm{Q}, \mathrm{B}, \mathrm{Z}$ ) e menos motivadas (S, R, N, M, L, H, F, J, X), e retiramos todas as palavras em que a primeira sílaba não tivesse total transparência ortográfica - caracterizada pela regularidade segundo a qual cada letra é representada somente por um fonema e vice-versa. Portanto, retiramos as letras: D, C, G, Q, Z, S, H, F, J e X.

Em relação ainda às primeiras sílabas formadas por "consoante + e" ou "consoante +o", foram escolhidas aquelas cuja realização se aproxima à forma como o nome da letra é pronunciado na cidade de São Paulo, local da amostra, que é o fonema [e] - como em "TEMIDA" e não como em "TÉTANO", no qual a letra "e" tem som de [ع]; ou ao fonema /O/ (como em "CÔMODA") e não /D/ (como em "CÓLICA").

A lista de palavras iniciadas por sílabas motivadas foi dividida, então, em dois grupos: um composto por quatro palavras formadas por consoante motivada + vogal $\mathrm{E}$, para que o contexto silábico fosse totalmente motivado, ou seja, que a sílaba coincidisse com o nome da consoante utilizada - esse grupo de palavras foi chamado de "Palavras com sílabas iniciais motivadas"; e outro grupo formado por quatro palavras formadas por consoante motivada + 
outra vogal que não "E”, para que a sílaba, apesar de formada por uma consoante motivada, não coincidisse com o nome da letra. Esse grupo de palavras foi chamado de "Palavras com sílabas iniciais de contraste".

A lista de "Palavras iniciadas por sílabas não motivadas" foi formada por quatro palavras iniciadas por letras sem motivação fonológica.

As palavras ditadas foram:

Tabela 15: Categorias de palavras, de acordo com a motivação fonológica da primeira sílaba

\begin{tabular}{ccc}
\hline $\begin{array}{c}\text { Palavras com sílabas } \\
\text { iniciais motivadas }\end{array}$ & $\begin{array}{c}\text { Palavras com sílabas iniciais } \\
\text { de contraste }\end{array}$ & $\begin{array}{c}\text { Palavras com sílabas } \\
\text { iniciais sem motivação }\end{array}$ \\
\hline Temida & Tomada & Rapina \\
Peluda & Paleta & Novena \\
Verina & Víbora & Muleta \\
Bexiga & Buzina & Luneta \\
\hline
\end{tabular}

Essa organização favorece três tipos de análise: uma em que se comparam os resultados para as "palavras com sílabas iniciais motivadas" com "palavras iniciadas por sílabas sem motivação fonológica"; outra comparando as "palavras com sílabas iniciais motivadas" com as "palavras iniciadas por sílabas de contraste"; e outra que compara "palavras iniciadas por sílabas de contraste" com "palavras iniciadas por sílabas sem motivação fonológica".

Com essa tarefa, podemos observar a influência do conhecimento do nome das letras e o nível de conceitualização da escrita no momento de tomada de decisões sobre a grafia das palavras que se deseja escrever, bem como se o êxito nessa tarefa exerce alguma influência sobre as demais.

Portanto, foram apresentados às crianças uma folha em branco e um lápis, ao que solicitamos que escrevessem seu nome e, em seguida, as palavras ditadas, uma a uma, verbalizando em voz alta à medida em que fossem escrevendo. O ditado foi iniciado por uma palavra motivada, seguida por uma palavra sem motivação, seguida por uma palavra do grupo de contraste.

Após a escrita de cada palavra, foi solicitado que lessem lentamente, indicando com o dedo as respectivas partes para evidenciar como justificavam suas produções e, desse modo, conhecermos as conceitualizações construídas sobre o sistema de escrita. As respostas foram organizadas de acordo com as seguintes possibilidades de escritas encontradas na amostra: 
a. Escrever a vogal pertinente: as crianças utilizaram apenas a vogal que compõe a sílaba para representá-la, por exemplo: representaram o "TO" de "TOMADA" somente com a letra "O" - OAA;

b. Escrever uma vogal não pertinente: as crianças utilizaram uma vogal que não compõe a sílaba, por exemplo: representaram a sílaba "TO" de "TOMADA" com a vogal "I" - IEA;

c. Escrever uma vogal próxima: as crianças utilizaram uma vogal que é fonologicamente próxima, por exemplo: para "TO" (TOMADA), escreveram "U”;

d. Escrever a consoante pertinente: as crianças utilizaram apenas a consoante que compõe a sílaba para representá-la, por exemplo: representaram o "TO" de "TOMADA" somente com a letra "T" - TOA;

e. Escreve uma consoante não pertinente: as crianças utilizaram uma consoante que não compõe a sílaba, por exemplo: representaram a sílaba "TO" de "TOMADA" com a consoante "J" - JEA;

f. Escreve uma consoante próxima: as crianças utilizaram uma consoante que é fonologicamente próxima, por exemplo: para “TO” (TOMADA), escreveram “D”;

g. Escrever a consoante e a vogal pertinentes: as crianças representaram convencionalmente a sílaba, ou seja, utilizaram tanto a consoante quanto a vogal que a compõem. Por exemplo, representaram o "TO" de "TOMADA" com “TO" - TOAD;

h. Escrever uma consoante e uma vogal não pertinentes: as crianças representaram a sílaba com duas letras, porém nenhuma corresponde às letras convencionais. Por exemplo, representaram o "TO" de "TOMADA" com "VA".

\section{b. Tarefa de identificar letras}

O objetivo dessa tarefa foi observar o conhecimento que as crianças têm do nome das letras quando elas são apresentadas fora do contexto de uso.

As letras, em calibri 60 pontos, cor preta, foram distribuídas aleatoriamente em uma folha em branco, tamanho A4. Foram omitidas da lista as letras W e Y, por serem pouco frequentes no português-brasileiro, totalizando 24 letras apresentadas.

A tarefa, semelhante à utilizada por Cano e Vernon (2008) e Fernández (2015), consistiu em perguntar às crianças se elas sabiam qual era cada letra apontada e solicitar que dissessem o respectivo nome. As respostas foram registradas tal como foram ditas. 
Os resultados foram organizados de acordo com as seguintes possibilidades de respostas:

a. Nomear convencionalmente: as crianças identificaram a letra com seu nome convencional, por exemplo, diante da letra "G", disseram "gê";

b. Aludir a um fonema: as crianças mencionaram o fonema convencional que representava a letra apontada. Por exemplo, diante da letra "B", disseram /b/;

c. Aludir ao contexto silábico: as crianças identificaram a letra por meio de uma sílaba que a continha, por exemplo, diante da letra "F", disseram "é a /fa/";

d. Aludir ao início da palavra: as crianças identificaram a letra dando como referente uma palavra que a continha no início. Por exemplo: diante da letra "M", disseram "é a da mamãe";

e. Aludir à palavra sem considerar o início: as crianças identificaram a letra dando como referente uma palavra que a continha, mas não no início. Por exemplo, diante da letra "Z", disseram "azul”;

f. Não identifica a letra: as crianças, diante da letra, referiram não saber qual era, não oferecendo nenhum tipo de resposta, ou a relacionaram de acordo com suas formas: "a cobrinha" ou com números "o dois";

g. Outra letra sem relação: as crianças identificaram como letras, mas referiram seus nomes arbitrariamente, por exemplo, diante da letra "C", referiram "é a /jota/".

Os resultados encontrados nessa tarefa ajudarão a analisar se a possibilidade de identificação é influenciada pela conceitualização que a criança tem sobre o sistema de escrita e se identificar letras influencia na produção escrita e na tarefa de completar palavras.

\section{c. Tarefa de completar palavras}

O objetivo dessa tarefa foi observar como as crianças utilizavam o conhecimento que tinham sobre os nomes das letras no momento de completar palavras; e se a coincidência entre o contexto silábico e o nome da letra, ou seja, a motivação fonológica, foi uma informação relevante para realizar essa tarefa.

Para isso, apresentamos individualmente doze palavras escritas sem a letra inicial (o lugar destas foi ocupado por um espaço em branco, sublinhado), e a criança deveria selecionar, entre cinco opções de letras, a que correspondesse ao segmento omitido. O entrevistador, seguindo o protocolo de Alvarado (1997), apresentava a palavra escrita, com a letra inicial 
omitida, e proporcionava às crianças a emissão oral da palavra completa, utilizando a seguinte consigna: "quero que diga mas falta a primeira, dessa forma diz (mencionando a palavra sem a letra inicial). Qual dessas (apontando para as letras escritas) serve para que diga ". Exemplo: “Quero que diga PATO, mas falta a primeira, dessa forma diz ATO. Qual dessas serve para que diga PATO?

Para a seleção das palavras partimos das listas de letras mais motivadas fonologicamente e não motivadas fonologicamente, organizadas de acordo com a frequência de aparição no português-brasileiro (Tabela 14).

A partir de um dicionário escolar listamos todas as palavras dissílabas, por ser esta a segunda extensão mais frequente do português, e para que as crianças tivessem menos segmentos com os quais lidar, fazendo com que o contexto da palavra fosse o mais reduzido possível. Como nessa tarefa as crianças não teriam o desafio de escrever, mas sim o de lidar com a palavra já parcialmente escrita, o fato de ser dissílabo não teria impacto em suas hipóteses sobre a organização do sistema de escrita. Tivemos cuidado apenas em relação à variabilidade entre as sílabas das palavras, tanto do núcleo vocálico quanto do ataque silábico. Isso porque acreditamos que a ocorrência de letras iguais poderia interferir na escolha da letra que completaria a palavra. Por isso, palavras como DEDO e DADO foram excluídas por repetirem a letra $\mathrm{D}$, assim como palavras como MALA, por repetir a letra A.

Dessa forma, foram listadas somente as dissílabas formadas por sílabas simples, cuja estrutura é a mais recorrente no português-brasileiro - CV-CV - que não fossem compostas por sílabas repetidas.

Dessa lista, selecionamos as palavras iniciadas pelas letras mais motivadas (D, T, C, P, $\mathrm{V}, \mathrm{G}, \mathrm{Q}, \mathrm{B}, \mathrm{Z}$ ) e menos motivadas (S, R, N, M, L, H, F, J, X), e retiramos todas as palavras em que a primeira sílaba não tivesse total transparência ortográfica - caracterizada pela regularidade, segundo a qual cada letra é representada somente por um fonema. Foram excluídas todas as palavras iniciadas por letras que representassem mais de um fonema e todas nas quais ocorria a nasalização da primeira sílaba.

Em relação ainda às primeiras sílabas formadas por "consoante + e" ou "consoante +o", foram escolhidas aquelas cuja realização se aproxima da forma como o nome da letra é pronunciado na cidade de São Paulo, que é o fonema [e] - como em "beco" e não como em "beca", no qual a letra "e" tem som de $[\varepsilon]$; ou o fonema /O/ (como em "coma") e não /D/ (como em "copa"). 
A lista de palavras iniciadas por sílabas motivadas foi dividida, então, em dois grupos: um composto por quatro palavras formadas por consoante motivada + vogal $\mathrm{E}$ para que o contexto silábico fosse totalmente motivado, ou seja, que a sílaba coincidisse com o nome da consoante utilizada - esse grupo de palavras foi chamado de "Palavras com sílabas iniciais motivadas"; e outro grupo formado por quatro palavras formadas pela consoante motivada + outra vogal que não a "E", para que a sílaba, apesar de formada por uma consoante motivada, não coincidisse com o nome da letra - esse grupo de palavras foi chamado de "Palavras com sílabas iniciais de contraste".

A lista de "Palavras iniciadas por sílabas não motivadas" foi formada por quatro palavras iniciadas por letras sem motivação fonológica.

As palavras ditadas foram:

Tabela 16: Categorias de palavras, de acordo com a motivação fonológica da primeira sílaba.

\begin{tabular}{ccc} 
1a sílaba motivada & Contrastante & Não motivadas \\
\hline TEMA & TOMA & RATO \\
PENA & PUMA & LIMA \\
VEJO & VILA & MULA \\
BECO & BOCA & NUCA \\
\hline
\end{tabular}

Essa organização favorece três tipos de análises: uma em que se comparam os resultados para as "palavras com sílabas iniciais motivadas" com "palavras iniciadas por sílabas sem motivação fonológica", outra comparando as "palavras com sílabas iniciais motivadas" com as "palavras iniciadas por sílabas de contraste"; e outra que compara "palavras iniciadas por sílabas de contraste" com "palavras iniciadas por sílabas sem motivação fonológica".

Com essa tarefa podemos observar a influência do conhecimento do nome das letras e do nível de conceitualização da escrita no momento de decidir qual letra serve para completar uma palavra e se o êxito nessa tarefa exerce alguma influência sobre as demais.

Portanto, foram apresentadas quatro palavras de cada tipo impressas em folhas individuais, formato retrato, escritas em letra maiúscula tipo Calibri de 30 pontos, pretas, com o fundo branco. A palavra centralizada no extremo superior da página e as opções de letras no inferior: 


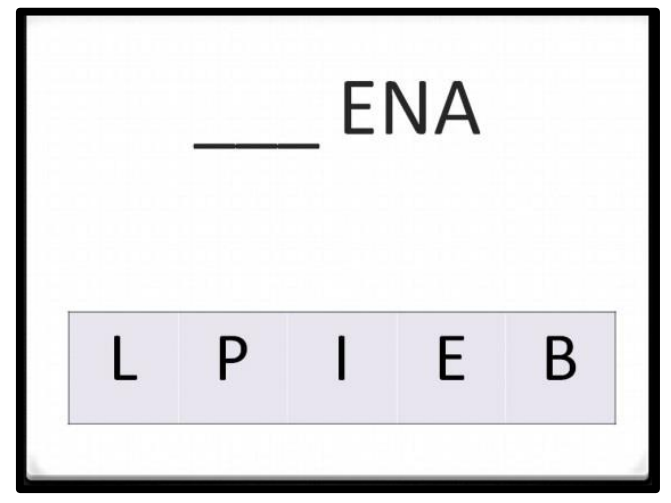

Figura 3 - Modelo da prova apresentada

Para cada palavra foram disponibilizadas cinco letras para que a criança escolhesse qual julgava completar a palavra escrita de modo a dizer aquilo que se propunha. A escolha das letras apresentadas obedeceu aos seguintes critérios:

(1) Letra alvo - que mostra que a criança conhece o uso da letra em questão;

(2) Vogal que compõe a sílaba - mostra que a criança pode estar fazendo uma análise silábica;

(3) Outra vogal;

(4) Uma letra próxima fonologicamente, de acordo com o traço de sonoridade, em que o ponto e o modo de articulação fossem os mesmos;

(5) Uma letra distante em todos os aspectos da letra alvo, que mostraria que a criança ainda não está pensando sobre o valor sonoro das letras.

Na Tabela 17 apresentam-se as palavras e as opções de letras oferecidas de acordo com a categorização estabelecida. 
Tabela 17: Relação das palavras e opções de letras, na ordem em que foram apresentadas.

\begin{tabular}{ccccccc}
\hline Palavra & $\begin{array}{c}\text { Letra } \\
\text { Alvo }\end{array}$ & $\begin{array}{c}\text { Vogal } \\
\text { que } \\
\text { compõe a } \\
\text { sílaba }\end{array}$ & $\begin{array}{c}\text { Outra } \\
\text { vogal }\end{array}$ & $\begin{array}{c}\text { Próxima } \\
\text { fonológicamente }\end{array}$ & Distante \\
\hline 1 & TOMA & T & O & E & D & J \\
2 & RATO & R & A & E & Q & N \\
3 & VEJO & V & E & - & F & L \\
4 & PUMA & P & U & E & B & C \\
5 & NUCA & N & U & E & B & C \\
6 & TEMA & T & E & - & D & J \\
7 & VILA & V & I & E & F & L \\
8 & MULA & M & U & E & N & T \\
9 & PENA & P & E & - & B & C \\
10 & BOCA & B & O & E & P & N \\
11 & LIMA & L & I & E & N & J \\
12 & BECO & B & E & - & P & J \\
\hline
\end{tabular}

\subsection{Desenho para análise dos resultados}

O desenho para analisar os dados foi feito da seguinte maneira:

a. Para analisar o nível de escrita e sua relação com a possibilidade de identificar letras fora do contexto, completar palavras e escrever palavras, utilizamos o Coeficiente de Correlação de Pearson, com a correção de Rô Spearman, e, assim, verificamos se as correlações entre o nível de escrita e as demais variáveis eram estatisticamente significativas;

b. Para verificar se a diferença entre as médias de palavras escritas, letras identificadas fora do contexto e palavras completadas com ou sem motivação fonológica eram estatisticamente significativas, usamos o Test T de Student;

c. Para analisar e comparar o comportamento das médias, usamos o teste ANOVA;

d. Para verificar a relação entre identificar letras, escrever e completar palavras, realizamos uma análise qualitativa multivariada dos dados.

\subsection{Amostra: critérios para seleção e descrição geral dos participantes}

A pesquisa teve por objetivo investigar as concepções pré-alfabéticas da população infantil. Por essa razão, a amostra com que trabalhamos foi composta por 48 crianças que cursavam a última série da Educação Infantil em escolas públicas na região central da cidade 
de São Paulo, Brasil - com isso garantimos que a procedência social das crianças fosse equivalente. A idade média dos participantes era de 5 a 6 anos de idade no momento do levantamento dos dados. A amostra foi formada por crianças de 4 escolas, devido à dificuldade em compor o grupo de 16 crianças com escritas silábico-alfabéticas.

Sabemos que a procedência social exerce grande influência em relação ao acesso à cultura escrita e, consequentemente, pode potencializar ou não as reflexões que as crianças fazem sobre o escrito. Também tem grande influência as práticas de ensino a que estão submetidas as crianças - se convidam a criança à reflexão ou à memorização, se atribuem sentido à aprendizagem ou se a descontextualizam. No entanto, a variável independente fundamental deste estudo foi o nível conceitual apresentado pelas crianças da amostra: como escrevem, identificam letras e completam palavras as crianças de cada nível conceitual?

Como dito anteriormente, o foco desse trabalho esteve posto sobre o nível de conceitualização da escrita, por isso, dividimos a amostra em três subgrupos, de acordo com o nível de escrita demonstrado por meio da tarefa de escrita: Silábico Sem Valor Sonoro Convencional (SSVSC), Silábico Com Valor Sonoro Convencional (SCVSC), e AS (Silábicoalfabético). Os três grupos foram formados com a mesma quantidade de crianças - 16 crianças.

\subsection{Características das sessões de entrevista}

Para reunir os dados presentes neste estudo, organizamos sessões individuais, nas quais aplicamos as tarefas que serão descritas no próximo item. Cada sessão teve a duração de 40 minutos e foi iniciada sempre com a tarefa de escrita, determinante para a seleção da amostra, que teve um sistema de cotas segundo o nível de escrita. O objetivo foi o de reunir 16 crianças com escritas silábicas sem valor sonoro convencional, 16 crianças com escritas silábicas com valor sonoro convencional, e 16 crianças com escritas silábica-alfabéticas. Ao realizarmos a tarefa de escrita e identificarmos produções pré-silábicas ou alfabéticas, não era dada continuidade à testagem das outras tarefas. Por outro lado, com as crianças silábicas foram aplicadas as demais tarefas até completar a cota de seu respectivo grupo. 


\section{CAPÍTULO 3. ANÁLISE E DISCUSSÃO DOS RESULTADOS}

\subsection{Análise da tarefa de escrita de substantivos}

$\mathrm{Na}$ tarefa de escrita de palavras as crianças deveriam escrever "do seu melhor jeito" as palavras ditadas pelo entrevistador. Os segmentos silábicos que consideramos para nossa análise foram as sílabas iniciais: /ra/,/to/,/pa/,/vi/,/lu/, /bu/,/no/, /pe/,/be/, /te/,/ve/. As escritas das crianças foram agrupadas na Tabela 18, de acordo com as categorias de análise, e organizadas dispondo as palavras segundo a quantidade de respostas - das mais convencionais para as menos convencionais-, sendo a mais convencional correspondente à escrita da sílaba completa $(\mathrm{CV})$ pertinente.

Tabela 18: Porcentagem de respostas para cada palavra segundo categorias de análise $(\mathbf{n}=\mathbf{4 8})$

\begin{tabular}{lccccccc}
\hline & $\begin{array}{c}\text { CV } \\
\text { pertinentes }\end{array}$ & $\begin{array}{c}\text { Vogal } \\
\text { pertinente }\end{array}$ & $\begin{array}{c}\text { Cons. } \\
\text { pertinente }\end{array}$ & $\begin{array}{c}\text { Cons. } \\
\text { próxima }\end{array}$ & $\begin{array}{c}\text { Vogal } \\
\text { próxima }\end{array}$ & $\begin{array}{c}\text { CV não } \\
\text { pertinentes }\end{array}$ & $\begin{array}{c}\text { Total por } \\
\text { linha }\end{array}$ \\
\hline RA (rapina) & 31,25 & 35,42 & 10,42 & 0,00 & 0,00 & 22,92 & 100,00 \\
TO (tomada) & 29,17 & 33,33 & 8,33 & 2,08 & 10,42 & 16,67 & 100,00 \\
PA (paleta) & 27,08 & 37,50 & 14,58 & 2,08 & 0,00 & 18,75 & 100,00 \\
VI (víbora) & 27,08 & 18,75 & 27,08 & 0,00 & 0,00 & 27,08 & 100,00 \\
LU (luneta) & 27,08 & 35,42 & 10,42 & 0,00 & 8,33 & 18,75 & 100,00 \\
BU (buzina) & 25,00 & 25,00 & 14,58 & 0,00 & 12,50 & 22,92 & 100,00 \\
NO (novena) & 25,00 & 37,50 & 6,25 & 0,00 & 8,33 & 22,92 & 100,00 \\
MU (muleta) & 14,58 & 41,67 & 8,33 & 0,00 & 14,58 & 20,83 & 100,00 \\
PE (peluda) & 10,42 & 8,33 & 58,33 & 2,08 & 0,00 & 20,83 & 100,00 \\
BE (bexiga) & 8,33 & 6,25 & 56,25 & 8,33 & 0,00 & 20,83 & 100,00 \\
TE (temida) & 4,17 & 8,33 & 56,25 & 6,25 & 0,00 & 25,00 & 100,00 \\
VE (verina) & 4,17 & 8,33 & 56,25 & 2,08 & 0,00 & 29,17 & 100,00 \\
\hline Total \% & 19,44 & 24,65 & 27,26 & 1,91 & 4,51 & 22,22 & 100,00 \\
Total & 112 & 142 & 157 & 11 & 26 & 128 & 576 \\
Frequência & & & & & & & \\
\hline
\end{tabular}

As sílabas iniciais que tiveram maior quantidade de respostas convencionais (CV pertinentes) foram "Rapina" e "Tomada" (praticamente 1/3 da amostra), ao passo que "Verina" e "Temida" tiveram a menor quantidade de respostas convencionais (ambas com $4,17 \%$ da amostra). 
"Muleta", "Novena" e "Paleta" foram as palavras que mais sistematicamente foram representadas por vogais pertinentes, e "Peluda", "Bexiga", "Verina" e "Temida" as que mais foram representadas por consoantes pertinentes.

Apesar da pequena ocorrência de respostas do tipo "consoante próxima" $(1,91 \%)$, as sílabas que tiveram maior incidência de escritas dessa natureza foram BE, de $\operatorname{BEXIGA~}(8,33 \%)$, e TE, de TEMIDA (6,25\%), cujas escritas utilizaram os respectivos pares fonêmicos (P e D), nas quais o único traço distintivo é a presença da sonorização, já que o modo e o ponto de articulação são os mesmos.

Em todas as sílabas iniciais que foram escritas com “vogais próximas”, o núcleo silábico era constituído pela letra O ou U: "Tomada", "Buzina", "Luneta", "Novena", "Muleta". As demais sílabas, formadas por A, E ou I, não foram representadas por vogais próximas, nem mesmo a palavra "Bexiga", que em algumas variações do português é pronunciada como "Bixiga".

As sílabas que tiveram maior incidência de escritas não pertinentes (consoantes ou vogal não pertinente e CV não pertinentes) foram VE (verina) e VI (víbora), ambas compostas pelo fonema fricativo labiodental sonoro, produzido com um fluxo contínuo de ar.

Para realizar a análise mais detalhadamente, essas oito categorias de respostas (vogal pertinente, não pertinente e próxima; consoante pertinente, não pertinente e próxima; consoante e vogal pertinente e não pertinente) foram reagrupadas de forma resumida em dois grupos, um que reuniu as respostas pertinentes e outro que continha as respostas não pertinentes. Para a análise realizada neste trabalho, seremos estritas ao considerar pertinentes as ocasiões em que a criança escreveu a consoante ou a vogal que convencionalmente compõem a sílaba (C pertinente ou V pertinente), e quando as escreveu de forma completa (CV). A Tabela 19 resume o agrupamento realizado.

Tabela 19: Descrição das categorias que compõem os agrupamentos mais e menos pertinentes

\begin{tabular}{ll}
\hline Respostas mais pertinentes & Respostas menos pertinentes \\
\hline Vogal pertinente & Vogal não pertinente \\
Consoante pertinente & Consoante não pertinente \\
Consoante e vogal pertinente & Consoante e vogal não pertinente \\
& Consoante próxima \\
& Vogal próxima \\
\hline
\end{tabular}


Ao organizarmos as respostas nesses dois grupos identificamos que, das 576 respostas obtidas (48 respostas x 12 sílabas analisadas), 71,35\% (411 casos) foram de tipo pertinente, contra 28,65\% (165 casos) de respostas não pertinentes, como mostra a Tabela 20.

Tabela 20: Porcentagem de respostas pertinentes e não pertinentes para cada palavra $(\mathbf{n}=$ 576)

\begin{tabular}{lccc}
\hline & Pertinente & $\begin{array}{c}\text { Não } \\
\text { Pertinente }\end{array}$ & $\begin{array}{c}\text { Total por } \\
\text { linha }\end{array}$ \\
\hline PA (paleta) & 79,17 & 20,83 & 100,00 \\
PE (peluda) & 77,08 & 22,92 & 100,00 \\
RA (rapina) & 77,08 & 22,92 & 100,00 \\
VI (víbora) & 72,92 & 27,08 & 100,00 \\
LU (luneta) & 72,92 & 27,08 & 100,00 \\
TO (tomada) & 70,83 & 29,17 & 100,00 \\
BE (bexiga) & 70,83 & 29,17 & 100,00 \\
TE (temida) & 68,75 & 31,25 & 100,00 \\
VE (verina) & 68,75 & 31,25 & 100,00 \\
NO (novena) & 68,75 & 31,25 & 100,00 \\
BU (buzina) & 64,58 & 35,42 & 100,00 \\
MU (muleta) & 64,58 & 35,42 & 100,00 \\
\hline Total \% & 71,35 & 28,65 & 100,00 \\
Total & 411 & 165 & 576 \\
Frequência & & & \\
\hline
\end{tabular}

Nesse reagrupamento, as palavras com maior índice de respostas pertinentes na primeira sílaba foram "Paleta", "Peluda" e "Rapina", e as com menor índice de respostas pertinentes foram "Novena", "Muleta" e "Buzina".

Esse dado mostra a grande probabilidade de as crianças usarem as letras com pertinência na $1^{\mathrm{a}}$ sílaba, ainda que suas representações sejam incompletas.

Entre as respostas pertinentes (411 casos), encontramos que o caso mais frequente foi o da utilização de uma consoante para representar o segmento inicial da palavra $(38,2 \%)$, seguido pela utilização da vogal pertinente $(34,5 \%)$, e, por último, pela representação convencional da sílaba $(27,3 \%)$. Conforme a Tabela 21: 
Tabela 21: Frequência e Porcentagem de cada tipo de resposta pertinente $(n=411)$

\begin{tabular}{llc}
\multicolumn{1}{c}{$\begin{array}{c}\text { Tipo de } \\
\text { resposta }\end{array}$} & $\begin{array}{c}\text { Total de } \\
\text { respostas }\end{array}$ \\
\hline Consoante & Frequência & 157 \\
pertinente & Porcentagem & 38,20 \\
Vogal & Frequência & 142 \\
pertinente & Porcentagem & 34,55 \\
CV pertinente & Frequência & 112 \\
& Porcentagem & 27,25 \\
\hline Total de & Frequência & 411 \\
respostas & Porcentagem & 100 \\
\hline
\end{tabular}

Ao aplicarmos o Teste $T$ de Student para observar o comportamento das crianças nas três categorias de resposta pertinente, observamos que houve uma diferença significativa entre as respostas que utilizaram a sílaba completa ( $\mathrm{CV}$ pertinente) e a vogal pertinente $(\mathrm{T}=0,03)$; uma diferença importante, ainda que menor, entre o uso da sílaba completa (CV pertinente) e a consoante $(T=0,2)$; e uma diferença estatisticamente irrelevante entre utilizar a vogal pertinente e a consoante pertinente $(\mathrm{T}=0,4)$.

\subsubsection{Análise Por Grupo de Palavras}

Nesta parte realizaremos a análise das respostas no interior de cada grupo de palavras, que foram organizadas segundo a motivação fonológica da sílaba inicial: grupo de palavras iniciadas por sílaba motivada, grupo de palavras iniciadas por sílabas de contraste, grupo de palavras iniciadas por sílabas cuja consoante não tem motivação fonológica. Os dados foram organizados conforme apresenta a Tabela 22: 
Tabela 22: Frequência e porcentagem de respostas pertinentes e não pertinentes para cada grupo de palavras $(n=576)$

\begin{tabular}{ccccc}
\hline & Respostas & $\begin{array}{c}\text { Respostas } \\
\text { nẽo } \\
\text { pertinentes } \\
\text { potivadas }\end{array}$ & $\begin{array}{c}\text { Total por } \\
\text { linha }\end{array}$ \\
\hline \multirow{2}{*}{ Contraste } & Frequência & 137 & 55 & 192 \\
& Forcentagem & 71,35 & 28,65 & 100 \\
Forequência & 138 & 54 & 192 \\
Não & Frequência & 136 & 56,13 & 100 \\
\hline Totivadas de & Porcentagem & 70,83 & 29,17 & 192 \\
respostas & Frequência & 411 & 165 & 100 \\
\hline
\end{tabular}

Nos três grupos de palavras (Motivadas, Contraste e Não motivadas) encontramos maior concentração de respostas pertinentes $(71,35 \%)$.

Ao compararmos o comportamento das respostas, de acordo com a motivação fonológica da primeira sílaba, notamos que as quantidades de respostas pertinentes foram bastante equilibradas, pois a análise geral da amostra apresenta 137 (71,35\%) respostas pertinentes para sílabas motivadas, $138(71,88)$ para sílabas de contraste e $136(70,83 \%)$ para sílabas não motivadas. Essa equivalência pode ser comprovada estatisticamente pelo Teste $T$ de Student, que teve como resultados: Motivadas vs. Contraste $=0,49$; Motivadas vs. Não motivadas $=0,49 ;$ Contraste vs. Não motivadas $=0,43$.

Esse dado nos permite concluir que a motivação fonológica da primeira sílaba não influenciou as escolhas feitas pelas crianças.

Ao observarmos o comportamento das respostas pertinentes nos três grupos (Tabela 23), organizados segundo a motivação fonológica da primeira sílaba, encontramos que a maior quantidade de respostas convencionais ( $\mathrm{CV}$ pertinente) ocorreu no grupo das palavras iniciadas por sílabas de contraste. Entre as 112 respostas que utilizaram CV pertinentes, 52 (46,4\%) ocorreram no contexto da sílaba de contraste, seguida pela sílaba não motivada (42\%). A menor quantidade de respostas convencionais ( $\mathrm{CV}$ pertinentes) ocorreu com o grupo de palavras iniciadas por sílabas motivadas, apenas $11,6 \%$ (13 respostas). 
Tabela 23: Frequência e porcentagem de respostas pertinentes da tarefa de escrita, por tipo de motivação da sílaba inicial

\begin{tabular}{|c|c|c|c|c|c|}
\hline & & $\begin{array}{c}\text { Sílaba } \\
\text { motivada }\end{array}$ & $\begin{array}{l}\text { Sílaba de } \\
\text { contraste }\end{array}$ & $\begin{array}{c}\text { Sílaba não } \\
\text { motivada }\end{array}$ & $\begin{array}{c}\text { Total por } \\
\text { linha }\end{array}$ \\
\hline \multirow{4}{*}{$\begin{array}{l}\text { Consoante } \\
\text { pertinente }\end{array}$} & Frequência & 109 & 31 & 17 & 157 \\
\hline & $\%$ por linha $(\mathrm{N}=157)$ & 69,4 & 19,7 & 10,8 & 100,0 \\
\hline & $\begin{array}{l}\text { \%por motivação } \\
(\mathrm{N}=192)\end{array}$ & 56,8 & 16,1 & 8,9 & 81,8 \\
\hline & $\%$ no total & 26,5 & 7,5 & 4,1 & 38,2 \\
\hline \multirow{4}{*}{$\begin{array}{l}\text { Vogal } \\
\text { pertinente }\end{array}$} & Frequência & 15 & 55 & 72 & 142 \\
\hline & $\%$ por linha (142) & 10,6 & 38,7 & 50,7 & 100,0 \\
\hline & $\begin{array}{l}\text { \%por motivação } \\
(\mathrm{n}=192)\end{array}$ & 7,8 & 28,6 & 37,5 & 74,0 \\
\hline & $\%$ no total & 3,6 & 13,4 & 17,5 & 34,5 \\
\hline \multirow{4}{*}{$\begin{array}{l}\mathrm{CV} \\
\text { pertinente }\end{array}$} & Frequência & 13 & 52 & 47 & 112 \\
\hline & $\%$ por linha $(\mathrm{N}=112)$ & 11,6 & 46,4 & 42,0 & 100,0 \\
\hline & $\begin{array}{l}\text { \%por motivação } \\
\quad(\mathrm{n}=192)\end{array}$ & 6,8 & 27,1 & 24,5 & 58,3 \\
\hline & $\%$ no total & 3,2 & 12,7 & 11,4 & 27,3 \\
\hline \multirow{4}{*}{$\begin{array}{l}\text { Total de } \\
\text { respostas }\end{array}$} & Frequência & 137 & 138 & 136 & 411 \\
\hline & $\%$ por linha (resposta) & 33,3 & 33,6 & 33,1 & 100,0 \\
\hline & \%por motivação & 71,4 & 71,9 & 70,8 & 71,4 \\
\hline & $\%$ no total & 33,3 & 33,6 & 33,1 & 100,0 \\
\hline
\end{tabular}

No contexto "motivado", as crianças preferiram representar as palavras usando a consoante pertinente, já que, entre as 192 sílabas motivadas (4 palavras iniciadas por sílaba motivada $\mathrm{x}$ a quantidade de crianças, 48$), 109$ respostas $(56,8 \%)$ escreveram com a consoante pertinente.

Em relação às escritas das sílabas "de contraste" (que compartilham o início com as palavras "motivadas", mas com outro núcleo vocálico), houve equilíbrio entre a escolha pela vogal e pela CV pertinente (respectivamente $28,6 \%$ e $27,1 \%$ ). Sendo que apenas $16 \%$ utilizaram a respectiva consoante.

Nas sílabas não motivadas, a maioria das respostas pertinentes se concentrou na utilização da vogal (37,5\%), seguida pela escrita da sílaba completa, convencional (24,5\%), e, por último, as crianças recorreram ao uso somente da consoante $(8,9 \%)$.

A Figura 4 ilustra a distribuição do tipo de resposta pertinente $(\mathrm{C}, \mathrm{V}$ e $\mathrm{CV})$, segundo a motivação fonológica da sílaba: 


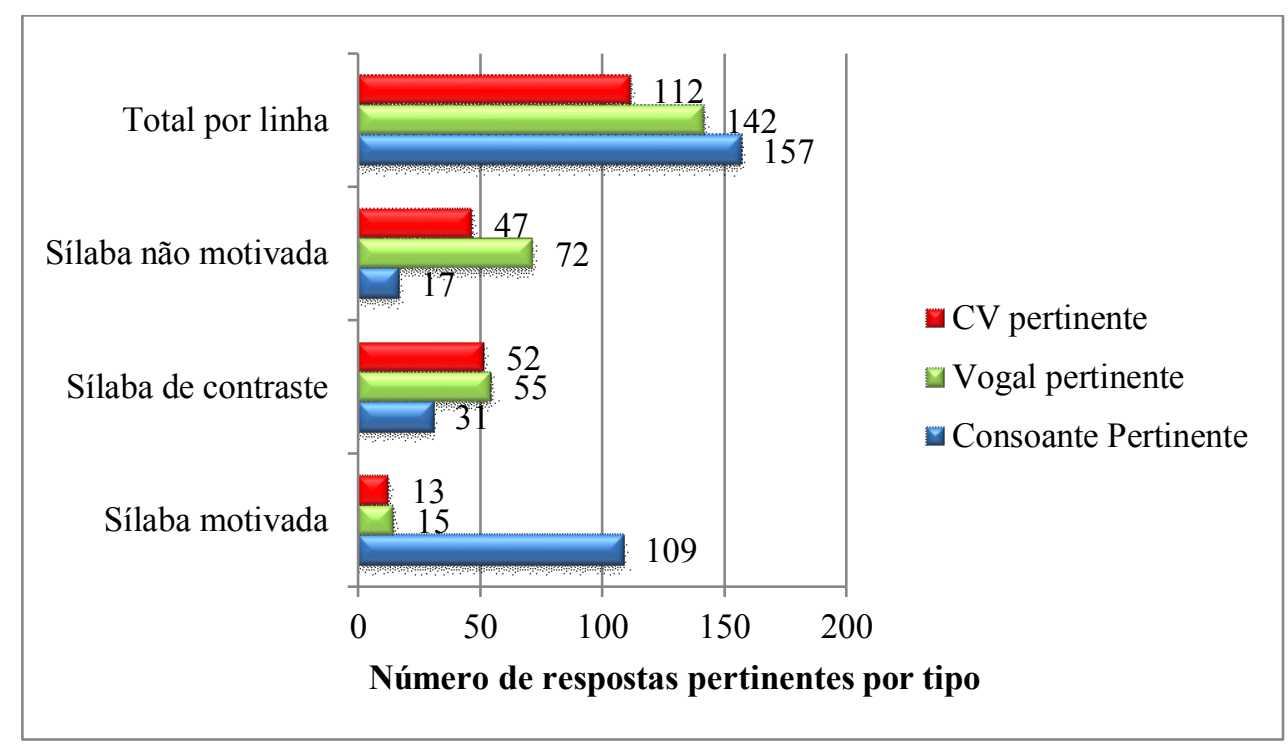

Figura 4 Distribuição das respostas pertinentes pela motivação fonológica da sílaba

Em uma primeira vista se nota uma tendência maior ao uso da consoante do que das vogais, porém, ao observar as respostas por blocos de agrupamento por tipo de palavra, podemos ver que esse efeito é produto da alta quantidade de uso de consoantes para as sílabas motivadas. Os dados reorganizados nos permitem apreciar que tanto para as palavras de contraste como para as não motivadas a estratégia de representação prioritária é o uso de vogais.

Observando detalhadamente a distribuição das porcentagens das respostas entre vogais e consoantes podemos notar que as sílabas iniciais motivadas foram as que concentraram maior uso de consoantes, ao contrário das não motivadas e de contraste, que captaram maior uso de vogais ou da escrita convencional.

Ao analisarmos as respostas considerando somente as que utilizaram vogal ou consoante pertinentes encontramos que as respostas foram bastante semelhantes: $81,8 \%$ utilizaram consoante e $74 \%$ utilizaram vogal. Tal semelhança pôde ser comprovada pelo Test $\mathrm{T}$, que indicou que, de fato, são estatisticamente semelhantes, $\mathrm{T}=0,5$.

Apesar de 56,8\% das sílabas motivadas terem sido escritas com a respectiva consoante, ao escreverem as sílabas de contraste, que utilizam a mesma letra inicial, as crianças optaram por utilizar as vogais pertinentes ou a sílaba completa. Esse resultado é especialmente interessante, pois a opção pelas consoantes no contexto motivado revela que as crianças conhecem a letra, já que nesse contexto o nome da sílaba e o nome da letra coincidem, no entanto, mesmo conhecendo-as e reconhecendo um de seus usos, não as utilizaram em contextos não motivados. 
Observamos, portanto, uma preferência pelo uso das consoantes somente no contexto motivado e pelas vogais no contexto não motivado (incluindo aqui as sílabas de contraste).

A seguir, analisaremos os dados dentro de cada grupo de palavras.

\subsubsection{Escrita de sílabas com motivação fonológica versus sílabas de contraste em posição inicial}

No grupo de palavras iniciadas por sílabas motivadas observamos que as respostas mais pertinentes $(\mathrm{CV}, \mathrm{C}$ e $\mathrm{V}$ pertinentes) representam $71,35 \%$ das respostas, enquanto as menos pertinentes representam $28,65 \%$, sendo que a maior porcentagem aparece sempre associada à utilização de uma consoante pertinente. Na Tabela 24, abaixo, vemos a distribuição dos tipos de respostas pelas palavras que compõem o grupo:

Tabela 24: Porcentagem e Frequência de sílabas motivadas na tarefa de escrita por palavra $(\mathrm{N}=192)$

\begin{tabular}{|c|c|c|c|c|c|c|}
\hline & & $\begin{array}{c}\text { CV } \\
\text { Pertinentes }\end{array}$ & $\begin{array}{c}\text { Vogal } \\
\text { pertinente }\end{array}$ & $\begin{array}{l}\text { Consoante } \\
\text { Pertinente }\end{array}$ & $\begin{array}{c}\text { Não } \\
\text { pertinentes }\end{array}$ & $\begin{array}{l}\text { Total por } \\
\text { linha }\end{array}$ \\
\hline \multirow{2}{*}{ TE(mida) } & Frequência & 2 & 4 & 27 & 15 & 48 \\
\hline & Porcentagem & 4,17 & 8,33 & 56,25 & 31,25 & 100 \\
\hline \multirow{2}{*}{ PE(luda) } & Frequência & 5 & 4 & 28 & 11 & 48 \\
\hline & Porcentagem & 10,42 & 8,33 & 58,33 & 22,92 & 100 \\
\hline \multirow{2}{*}{ VE(rina) } & Frequência & 2 & 4 & 27 & 15 & 48 \\
\hline & Porcentagem & 4,17 & 8,33 & 56,25 & 31,25 & 100 \\
\hline \multirow{2}{*}{ BE(xiga) } & Frequência & 4 & 3 & 27 & 14 & 48 \\
\hline & Porcentagem & 8,33 & 6,25 & 56,25 & 29,17 & 100 \\
\hline \multirow{2}{*}{$\begin{array}{l}\text { Total de } \\
\text { respostas }\end{array}$} & Frequência & 13 & 15 & 109 & 55 & 192 \\
\hline & Porcentagem & 6,77 & 7,81 & 56,77 & 28,65 & 100 \\
\hline
\end{tabular}

De acordo com os dados apresentados, as respostas convencionais (CV pertinente) foram mínimas - apenas 6,77\% (13 casos de 192). Entre as palavras ditadas, "Peluda" foi a que recebeu mais escritas convencionais $(10,42 \%)$ e "Temida" e "Verina" as que menos receberam (apenas 4,17\%). Contudo, a distância entre a porcentagem maior e a menor é de apenas 6,25\%. 
Se observarmos os dados considerando apenas a preferência das crianças por utilizar vogais ou consoantes $(\mathrm{N}=124-\mathrm{V}+\mathrm{C})$, encontramos que $87,9 \%$ das respostas apresentaram consoantes, enquanto que as demais (12\%), vogais.

No grupo de palavras iniciadas por sílabas de contraste observamos que as respostas mais pertinentes ( $\mathrm{CV}, \mathrm{C}$ e V pertinentes) representam $71,88 \%$ das respostas, enquanto as menos pertinentes representam 28,13\%. Na Tabela 25, vemos a distribuição dos tipos de respostas pelas palavras que compõem o grupo:

Tabela 25: Porcentagem e Frequência de sílabas de contraste na tarefa de escrita por palavra $(\mathbf{N}=192)$

\begin{tabular}{|c|c|c|c|c|c|c|}
\hline & & $\begin{array}{c}\text { CV } \\
\text { Pertinentes }\end{array}$ & $\begin{array}{c}\text { Vogal } \\
\text { pertinente }\end{array}$ & $\begin{array}{l}\text { Consoante } \\
\text { Pertinente }\end{array}$ & $\begin{array}{c}\text { Não } \\
\text { pertinentes }\end{array}$ & $\begin{array}{c}\text { Total por } \\
\text { linha }\end{array}$ \\
\hline \multirow{2}{*}{$\mathrm{TO}($ mada $)$} & Frequência & 14 & 16 & 4 & 14 & 48 \\
\hline & Porcentagem & 29,17 & 33,33 & 8,33 & 29,17 & 100 \\
\hline \multirow[t]{2}{*}{ PA(leta) } & Frequência & 13 & 18 & 7 & 10 & 48 \\
\hline & Porcentagem & 27,08 & 37,50 & 14,58 & 20,83 & 100 \\
\hline \multirow[t]{2}{*}{ VI(bora) } & Frequência & 13 & 9 & 13 & 13 & 48 \\
\hline & Porcentagem & 27,08 & 18,75 & 27,08 & 27,08 & 100 \\
\hline \multirow[t]{2}{*}{ BU(zina) } & Frequência & 12 & 12 & 7 & 17 & 48 \\
\hline & Porcentagem & 25,00 & 25,00 & 14,58 & 35,42 & 100 \\
\hline \multirow{2}{*}{$\begin{array}{c}\text { Total de } \\
\text { respostas }\end{array}$} & Frequência & 52 & 55 & 31 & 54 & 192 \\
\hline & Porcentagem & 27,08 & 28,65 & 16,15 & 28,13 & 100 \\
\hline
\end{tabular}

A maior porcentagem de respostas aparece igualmente distribuída entre vogal pertinente $(28,65 \%)$ e consoante e vogal pertinentes, ou seja, a sílaba completa e convencional $(27,08 \%)$, que, juntas, representam mais da metade das respostas dadas, o maior índice dos dados coletados $(55,73 \%)$.

Houve um equilíbrio entre as palavras ditadas, porém, a que foi escrita de modo convencional com maior frequência foi "Tomada" (29,17\%) e a que foi escrita menos vezes de modo convencional foi "Buzina" (25\%). A distância entre a porcentagem maior e a menor foi de apenas $4,17 \%$.

Ao observarmos a totalidade dos dados considerando a preferência das crianças por utilizar vogais ou consoantes $(\mathrm{N}=86)$, encontramos que $63,95 \%$ das respostas apresentam 
vogais e o restante $(36,04 \%)$, consoantes. Ou seja, nesse contexto silábico quase o dobro das crianças $(1,77$ vezes $)$ preferiu utilizar as vogais em relação às consoantes.

\subsubsection{Escrita de "sílabas de contraste" versus "sílabas sem motivação fonológica" em posição inicial}

No grupo de palavras iniciadas por sílabas sem motivação fonológica observamos que as respostas mais pertinentes $(\mathrm{CV}, \mathrm{C}$ e $\mathrm{V}$ pertinentes) representam 70,83\% das respostas, enquanto as menos pertinentes representam $29,17 \%$. Na Tabela 26 , observamos a distribuição dos tipos de respostas pelas palavras que compõem o grupo.

Tabela 26: Porcentagem e Frequência de sílabas não motivadas na tarefa de escrita por palavra $(\mathrm{N}=192)$

\begin{tabular}{clccccc}
\hline & & $\begin{array}{c}\text { CV } \\
\text { Pertinentes }\end{array}$ & $\begin{array}{c}\text { Vogal } \\
\text { pertinente }\end{array}$ & $\begin{array}{c}\text { Consoante } \\
\text { Pertinente }\end{array}$ & $\begin{array}{c}\text { Não } \\
\text { pertinentes }\end{array}$ & $\begin{array}{c}\text { Total por } \\
\text { linha }\end{array}$ \\
\hline \multirow{2}{*}{ RA(pina) } & Frequência & 15 & 17 & 5 & 11 & 48 \\
& Porcentagem & 31,25 & 35,42 & 10,42 & 22,92 & 100 \\
NO(vena) & Frequência & 12 & 18 & 3 & 15 & 48 \\
& Porcentagem & 25,00 & 37,50 & 6,25 & 31,25 & 100 \\
& & & & & & \\
MU(leta) & Frequência & 7 & 20 & 4 & 17 & 48 \\
& Porcentagem & 14,58 & 41,67 & 8,33 & 35,42 & 100 \\
& & 13 & 17 & 5 & 13 & 48 \\
LU(neta) & Frequência & 13 & 35,42 & 10,42 & 27,08 & 100 \\
& Porcentagem & 27,08 & 72 & 17 & 56 & 192 \\
\hline Total de & Frequência & 47 & 77,50 & 8,85 & 29,17 & 100 \\
respostas & Porcentagem & 24,48 & 37 & & & \\
\hline
\end{tabular}

Entre as respostas pertinentes, a maior porcentagem de respostas está relacionada à escolha das vogais $(37,50 \%)$, ficando em segundo lugar a resposta convencional (CV pertinente), 24,48\%. A escolha pelas respectivas consoantes para representar esse grupo foi de apenas $8,85 \%$ das respostas.

Tanto no grupo de contraste quanto no grupo não motivado foi mais frequente representar-se a sílaba inicial de forma completa e convencional (CV pertinente) do que representá-la somente pela consoante.

Entre as palavras ditadas, "Rapina" foi a que recebeu mais escritas convencionais (31,25\%) e "Muleta" a que recebeu menos escritas convencionais (apenas 14,58\%). A distância 
entre a porcentagem maior e a menor foi significativa, visto que o dobro das respostas foi convencional para representar "Rapina".

Se observarmos a totalidade dos dados considerando as preferências das crianças por utilizar vogais ou consoantes $(\mathrm{N}=89)$, encontramos que $88,89 \%$, apresentam vogais e o restante $(19,10 \%)$, consoantes.

Os dados sobre a escrita de palavras com sílabas iniciais de contraste e não motivadas são mais próximos que os obtidos com a escrita de palavras com sílabas motivadas.

Esses dados apontam para uma tendência a utilizar vogais quando os segmentos são menos motivados (contraste e não motivados) e a utilizar mais consoantes quando o segmento é motivado, conforme mostra a Tabela 27.

Tabela 27: Porcentagem e Frequência de respostas na tarefa de escrita por grupo de sílabas $(\mathbf{N}=192)$

\begin{tabular}{clccccc}
\hline & & $\begin{array}{c}\text { CV } \\
\text { Pertinentes }\end{array}$ & $\begin{array}{c}\text { Vogal } \\
\text { pertinente }\end{array}$ & $\begin{array}{c}\text { Consoante } \\
\text { Pertinente }\end{array}$ & $\begin{array}{c}\text { Não } \\
\text { pertinentes }\end{array}$ & $\begin{array}{c}\text { Total por } \\
\text { linha }\end{array}$ \\
\hline \multirow{2}{*}{ Motivadas } & Frequência & 13 & 15 & 109 & 55 & 192 \\
& Porcentagem & 6,77 & 7,81 & 56,77 & 28,65 & 100 \\
Contraste & Frequência & 52 & 55 & 31 & 54 & 192 \\
& Porcentagem & 27,08 & 28,65 & 16,15 & 28,13 & 100 \\
\multirow{2}{*}{$\begin{array}{c}\text { Não } \\
\text { motivadas }\end{array}$} & Frequência & 47 & 72 & 17 & 56 & 192 \\
& Porcentagem & 24,48 & 37,50 & 8,85 & 29,17 & 100 \\
\hline \multirow{2}{*}{$\begin{array}{c}\text { Total de } \\
\text { respostas }\end{array}$} & Frequência & 112 & 142 & 157 & 165 & 576 \\
\hline
\end{tabular}

Segundo Fernández (2015), as palavras iniciadas por sílabas compostas por fonemas mais contínuos ${ }^{27}$ possuem maior possibilidade de serem identificadas. Na presente pesquisa, apesar do critério de organização dos grupos de palavras não ter se orientado pela característica da contiguidade/prolongamento do fonema inicial, todas as palavras que compõem o grupo "não motivadas" possuem essa característica: são iniciadas por fonemas que têm a possibilidade de serem prolongados (três fricativos, $\mathrm{R}, \mathrm{M}, \mathrm{N}$, e um lateral, L). Contudo, o fato de serem iniciadas por fonemas mais contínuos não representou para esse grupo de palavras maior índice

\footnotetext{
${ }^{27}$ Fonemas mais contínuos são aqueles que têm maior possibilidade de serem prolongados durante a emissão, como /S/, /Z/, /F/, /V/, entre outros. Vale destacar que há pequenas diferenças entre o português e o espanhol, em relação ao traço de continuidade dos fonemas, como é o caso do /V/, que em português é um fonema contínuo e em espanhol, não. O trabalho de Fernandez (2015) se refere ao espanhol, por isso é necessário atenção, pois, ao realizar a transposição dos dados para o português, há de se considerar as diferenças entre os idiomas.
} 
de acerto, ou seja, a representação da sílaba com CV pertinente (24,48\%), quando comparado ao grupo de sílabas de contraste $(27,08 \%)$ - que é composto por três palavras em que as primeiras sílabas são iniciadas por fonemas não contínuos $(/ \mathrm{t} /, / \mathrm{b} / \mathrm{e} / \mathrm{p} /)$ e um fonema mais contínuo $(/ \mathrm{v} /)$. Vale retomar que esse traço parece não ter influenciado, visto que as sílabas iniciadas com $/ \mathrm{v} /$ foram, como explicitado em momento anterior, as que mais tiveram respostas do tipo não pertinente.

De acordo com o Teste $T$ de Student, os dois grupos (não motivadas e de contraste) se comportaram de modo semelhante $(\mathrm{T}=0,4)$.

\subsubsection{Análise Por Nível de Escrita}

Ao analisarmos o efeito que o nível de escrita tem sobre as respostas das crianças, observamos, como era previsível, que quanto mais avançado o nível, maior a quantidade de respostas convencionais. Como se pode observar na Tabela 28, as crianças com escrita silábicaalfabética (SA) tiveram maior quantidade de respostas pertinentes $(96,35 \%)$, seguidas pelas silábicas com valor sonoro convencional (SCVSC - 85,94\%) e as silábicas sem valor sonoro convencional (SSVSC), que tiveram menos acertos $(31,77 \%)$.

Tabela 28: Frequência e porcentagem de respostas "pertinentes" e "não pertinentes" por nível de escrita $(\mathrm{N}=576)$

\begin{tabular}{clccc}
\hline $\begin{array}{c}\text { Nível de } \\
\text { escrita }\end{array}$ & Pertinente & $\begin{array}{c}\text { Não } \\
\text { Pertinente }\end{array}$ & $\begin{array}{c}\text { Total por } \\
\text { linha }\end{array}$ \\
\hline SSVC & $\begin{array}{l}\text { Frequência } \\
\text { \% nível esc } \\
(\mathrm{n}=192)\end{array}$ & 61 & 131 & 192 \\
& \% total (n-=576) & 10,59 & 22,74 & 33,33 \\
& Frequência & 165 & 27 & 192 \\
SCVC & \% nível esc & & & \\
& (n=192) & 85,94 & 14,06 & 100,00 \\
& \% total (n-=576) & 28,65 & 4,69 & 33,33 \\
& $\begin{array}{l}\text { Frequência } \\
\text { SA nível esc }\end{array}$ & 185 & 7 & 192 \\
& $\begin{array}{l}\text { (n=192) } \\
\text { \% total (n-=576) }\end{array}$ & 32,12 & 1,22 & 33,33 \\
\hline Total de & Frequência & 411 & 165 & 576 \\
respostas & Porcentagem & 71,35 & 28,65 & 100,00 \\
\hline
\end{tabular}


Entre o grupo SSVC, 61 casos foram pertinentes, ou seja, 31,77\% das respostas. Esse valor representa $10,59 \%$ do total da amostra (576 palavras).

Os valores referentes ao grupo SCVSC têm um significativo aumento quando comparados ao grupo SSVC: 165 casos $(85,94 \%)$ foram de respostas pertinentes, o que representa na amostra quase o triplo da quantidade de acertos do grupo anterior.

Já em relação ao grupo SA, observa-se um incremento em relação ao grupo SCVC, mas que não pode ser considerado como significativo em uma análise global como essa. Apenas $10,41 \%$ a mais de acertos que o grupo SCVC.

\subsubsection{Análise por nível de escrita, segundo a motivação fonológica da $1^{\text {a }}$ sílaba}

Ao relacionarmos o nível conceitual e o tipo de palavra (motivada, contraste e não motivada), percebemos que o mesmo padrão se mantém independentemente do tipo de sílaba: conforme aumenta o nível de escrita, maior o índice de acertos. A Tabela 29, abaixo, traz essa relação.

Tabela 29: Frequência e porcentagens de respostas pertinentes por nível de escrita e tipo de palavra $(\mathrm{N}=411)$

\begin{tabular}{|c|c|c|c|c|c|}
\hline $\begin{array}{c}\text { Nível de } \\
\text { escrita }\end{array}$ & & Motivada & Contraste & $\begin{array}{c}\text { Não } \\
\text { motivada }\end{array}$ & $\begin{array}{c}\text { Total por } \\
\text { linha }\end{array}$ \\
\hline \multirow{3}{*}{ SSVC } & \multirow{3}{*}{$\begin{array}{l}\text { Frequência } \\
\% \text { nível esc } \\
(n=192) \\
\% \text { total }(n-=411)\end{array}$} & 22 & 21 & 18 & 61 \\
\hline & & 36,1 & 34,4 & 29,5 & 100,0 \\
\hline & & 5,35 & 5,11 & 4,38 & 14,84 \\
\hline \multirow{3}{*}{$\mathrm{SCVC}$} & \multirow{3}{*}{$\begin{array}{l}\text { Frequência } \\
\% \text { nível esc } \\
(\mathrm{n}=192) \\
\% \text { total }(\mathrm{n}-=411)\end{array}$} & 55 & 56 & 54 & 165 \\
\hline & & 33,3 & 33,9 & 32,7 & 100,0 \\
\hline & & 13,38 & 13,63 & 13,14 & 40,15 \\
\hline \multirow{3}{*}{ SA } & \multirow{3}{*}{$\begin{array}{l}\text { Frequência } \\
\% \text { nível esc } \\
(n=192) \\
\% \text { total }(n-=411)\end{array}$} & 60 & 61 & 64 & 185 \\
\hline & & 32,4 & 33,0 & 34,6 & 100,0 \\
\hline & & 14,60 & 14,84 & 15,57 & 45,01 \\
\hline \multirow{2}{*}{$\begin{array}{l}\text { Total de } \\
\text { respostas }\end{array}$} & Frequência & 137 & 138 & 136 & 411 \\
\hline & $\%$ total & 33,33 & 33,58 & 33,09 & 100,00 \\
\hline
\end{tabular}


As crianças com escritas SSVC foram as que apresentaram menos respostas pertinentes no total $(14,84 \%)$ e em cada tipo de palavra $(5,35 \%, 5,11 \%$ e $4,38 \%)$. Em segundo lugar, estiveram as crianças SCVC (40,15\% de acerto no total da amostra), e, por fim, as escritas SA, que apresentaram as respostas mais pertinentes no total $(45,01 \%)$ e em todos os grupos de palavras. Ou seja, em todos os grupos de palavras as respostas estiveram associadas ao nível de escrita. A Tabela 30 resume os resultados das provas de Qui-quadrado realizadas.

Tabela 30: Testes de qui-quadrado para a representação pertinente da sílaba inicial

\begin{tabular}{lccc}
\hline & Valor & gl & $\begin{array}{c}\text { Sig. } \\
\text { asintótica } \\
\text { (bilateral) }\end{array}$ \\
\hline Motivada & 27,616 & 8 & 0,001 \\
Contraste & 66,057 & 12 & 0 \\
Não motivada & 33,707 & 8 & 0 \\
\hline
\end{tabular}

Sabemos que a maioria das crianças $(71,35 \%)$ empregou representação silábica pertinente para os segmentos iniciais. Entre as respostas pertinentes, as crianças utilizaram, sobretudo, consoantes (157 casos ou 38,19\%), mas esse valor foi influenciado pela grande escolha de consoantes para a escrita de palavras iniciadas por sílabas motivadas (109 casos ou $26,52 \%$ ). Inclusive, as crianças SSVC e as SCVC utilizaram mais as consoantes no contexto das sílabas motivadas, enquanto que nas de sílabas de contraste e não motivadas a maioria optou pelo uso da vogal (Contraste: SSVC $=17$ casos ou 4,13\% e SCVC $=36$ casos ou 8,75\%; Não motivadas: $\mathrm{SSVC}=17$ casos ou $4,13 \%$ e $\mathrm{SCVC}=48$ casos ou $11,67 \%$ ).

Já as crianças SA foram as que apresentaram a maior quantidade de escritas de sílabas convencionais nos três grupos de palavras. Também foram as que utilizaram menos vogais de maneira isolada.

A Tabela 31 mostra a quantidade e o tipo de respostas dadas pelas crianças, de acordo com a motivação fonológica da sílaba inicial e o nível de escrita. 
Tabela 31: Frequência de respostas para a representação de sílabas iniciais por tipo de sílaba e nível de escrita

\begin{tabular}{cccccc}
\hline $\begin{array}{c}\text { Tipo de } \\
\text { sílaba }\end{array}$ & $\begin{array}{c}\text { Nível de } \\
\text { escrita }\end{array}$ & $\begin{array}{c}\text { Vogal } \\
\text { pertinente }\end{array}$ & $\begin{array}{c}\text { Tipos de respostas } \\
\text { Consoante }\end{array}$ & $\begin{array}{c}\text { CV } \\
\text { pertinente }\end{array}$ & pertinente \\
\hline & SSV & 5 & 17 & 0 & 22 \\
Motivada & SCV & 8 & 47 & 0 & 55 \\
& SA & 2 & 45 & 13 & 60 \\
& Subtotal & $\mathbf{1 5}$ & $\mathbf{1 0 9}$ & $\mathbf{1 3}$ & $\mathbf{1 3 7}$ \\
& & & & & \\
Contraste & SSV & 17 & 4 & 0 & 21 \\
& SCV & 36 & 17 & 3 & 56 \\
& SA & 2 & 10 & 49 & 61 \\
& Subtotal & $\mathbf{5 5}$ & $\mathbf{3 1}$ & $\mathbf{5 2}$ & $\mathbf{1 3 8}$ \\
& & & & & \\
Não & SSV & 17 & 1 & 0 & 18 \\
Motivadannnyyyn & SCV & 48 & 6 & 0 & 54 \\
& SA & 7 & 10 & 47 & 64 \\
\hline Total & Subtotal & $\mathbf{7 2}$ & $\mathbf{1 7}$ & $\mathbf{4 7}$ & $\mathbf{1 3 6}$ \\
\hline
\end{tabular}

Para verificar a relação direta entre as respostas corretas e o nível de escrita, calculamos o Coeficiente da Correlação de Pearson, com correção de Rô Spearman, como mostra a Tabela 32: 
Tabela 32: Correlação de Rô Sperman entre o nível de escrita e o total de escritas convencionais $(\mathrm{CV})$ em cada grupo de palavras $(n=48)$

\begin{tabular}{|c|c|c|c|c|c|}
\hline & & $\begin{array}{c}\text { Nível } \\
\text { de } \\
\text { Escrita }\end{array}$ & $\begin{array}{c}\text { Total } \\
\text { Escreve } \\
\text { CV } \\
\text { Motivada }\end{array}$ & $\begin{array}{c}\text { Total } \\
\text { Escreve } \\
\text { CV Não } \\
\text { Motivada }\end{array}$ & $\begin{array}{c}\text { Total } \\
\text { Escreve } \\
\text { CV } \\
\text { Contraste }\end{array}$ \\
\hline Nível de Escrita & $\begin{array}{l}\text { Coeficiente de } \\
\text { Correlação } \\
\text { Sig. ( } 2 \text { extremidades })\end{array}$ & $\begin{array}{l}1 \\
.\end{array}$ & $\begin{array}{c}545^{* *} \\
0\end{array}$ & $\begin{array}{c}, 810^{* *} \\
0\end{array}$ & $\begin{array}{c}, 844^{*} \\
0\end{array}$ \\
\hline $\begin{array}{l}\text { Total Escreve } \\
\text { CV Motivada }\end{array}$ & $\begin{array}{l}\text { Coeficiente de } \\
\text { Correlação } \\
\text { Sig. ( } 2 \text { extremidades })\end{array}$ & $\begin{array}{c}545^{* *} \\
0\end{array}$ & $\begin{array}{l}1 \\
.\end{array}$ & $\begin{array}{c}, 560^{* *} \\
0\end{array}$ & $\begin{array}{c}589^{* *} \\
0\end{array}$ \\
\hline $\begin{array}{l}\text { Total Escreve } \\
\text { CV Não } \\
\text { Motivada }\end{array}$ & $\begin{array}{l}\text { Coeficiente de } \\
\text { Correlação } \\
\text { Sig. ( } 2 \text { extremidades })\end{array}$ & $\begin{array}{c}, 810^{* *} \\
0\end{array}$ & $\begin{array}{c}, 560^{* *} \\
0\end{array}$ & $\begin{array}{l}1 \\
.\end{array}$ & $\begin{array}{c}, 855^{* *} \\
0\end{array}$ \\
\hline $\begin{array}{l}\text { Total Escreve } \\
\text { CV Contraste }\end{array}$ & $\begin{array}{l}\text { Coeficiente de } \\
\text { Correlação } \\
\text { Sig. ( } 2 \text { extremidades })\end{array}$ & $\begin{array}{c}, 844^{*} \\
0\end{array}$ & $\begin{array}{c}, 589^{* *} \\
0\end{array}$ & $\begin{array}{c}, 855^{* *} \\
0\end{array}$ & 1 \\
\hline
\end{tabular}

**. A correlação é significativa no nível 0,01 (2 extremidades).

Conforme previsto, existe correlação positiva entre o uso da sílaba convencional e o nível de escrita, sendo que a correlação é forte nas sílabas de contraste e não motivadas e moderada nas sílabas motivadas. Estes dados sugerem que quando as crianças aumentam seus conhecimentos sobre a escrita, nesse momento, encontram-se, então, em melhores condições de escrever de modo mais convencional.

Para analisarmos o que ocorre com o uso das vogais e o nível de escrita, calculamos uma comparação do comportamento das médias (ANOVA). 
Tabela 33: Comparação de médias (ANOVA) entre o uso de vogais nos grupos de palavras

\begin{tabular}{clccccc}
\hline & & $\begin{array}{c}\text { Soma dos } \\
\text { quadrados }\end{array}$ & gl & $\begin{array}{c}\text { Média } \\
\text { quadrática }\end{array}$ & F & Sig. \\
\hline Total Escreve Vogal & Entre grupos & 2,04 & 2 & 1,021 & 1,674 & 0,199 \\
em Sílaba Motivada & Nos grupos & 27,44 & 45 &, 610 & & \\
& Total & 29,48 & 47 & & & \\
Total Escreve Vogal & Entre grupos & 61,54 & 2 & 30,771 & 29,858 &, 000 \\
em Sílaba de Não & Nos grupos & 46,38 & 45 & 1,031 & & \\
Motivada & Total & 107,92 & 47 & & & \\
Total Escreve Vogal & Entre grupos & 36,29 & 2 & 18,146 & 24,239 & \multirow{2}{*}{, 000} \\
em Sílaba de & Nos grupos & 33,69 & 45 &, 749 & & \\
Contraste & Total & 69,98 & 47 & & & \\
\hline
\end{tabular}

Os dados indicam que há um comportamento equivalente no uso das vogais para representar a sílaba inicial entre o grupo de palavras iniciadas por sílabas de contraste e o de palavras iniciadas por sílabas não motivadas. As únicas que diferem neste aspecto são as palavras com motivação fonológica na sílaba inicial.

Observamos que há uma correlação negativa (verificada pela correlação de Rô Sperman - Tabela 34) entre o uso das vogais e o nível de escrita de modo geral, ou seja, a possibilidade de uso da vogal não esteve atrelada ao nível de escrita, como mostra a Tabela 34. 
Tabela 34: Correlação de Rô Sperman entre o nível de escrita e o total de utilização de vogais em cada grupo de palavras $(n=48)$

\begin{tabular}{|c|c|c|c|c|c|}
\hline & & $\begin{array}{c}\text { Nível } \\
\text { de } \\
\text { Escrita }\end{array}$ & $\begin{array}{c}\text { Total } \\
\text { Escreve } \\
\text { Vogal em } \\
\text { Sílaba } \\
\text { Motivada }\end{array}$ & $\begin{array}{c}\text { Total } \\
\text { Escreve } \\
\text { Vogal em } \\
\text { Sílaba de } \\
\text { Não } \\
\text { Motivada } \\
\end{array}$ & $\begin{array}{c}\text { Total } \\
\text { Escreve } \\
\text { Vogal em } \\
\text { Sílaba de } \\
\text { Contraste }\end{array}$ \\
\hline \multirow[t]{2}{*}{ Nível de Escrita } & $\begin{array}{l}\text { Coeficiente de } \\
\text { Correlação }\end{array}$ & 1 &,- 278 &,- 231 & \\
\hline & Sig. (2 extremidades) & $\cdot$ &, 056 &, 114 &, 003 \\
\hline \multirow{2}{*}{$\begin{array}{c}\text { Total Escreve } \\
\text { Vogal em Sílaba } \\
\text { Motivada }\end{array}$} & Coeficiente de &,- 278 & 1 &, 030 &, 253 \\
\hline & $\begin{array}{l}\text { Correlação } \\
\text { Sig. (2 extremidades) }\end{array}$ & ,056 & & ,839 & 083 \\
\hline \multirow{2}{*}{$\begin{array}{c}\text { Total Escreve } \\
\text { Vogal em Sílaba } \\
\text { de Não Motivada }\end{array}$} & Coeficiente de &,- 231 &, 030 & 1 &, $712^{* *}$ \\
\hline & Sig. (2 extremidades) &, 114 & ,839 & & ,000 \\
\hline $\begin{array}{l}\text { Total Escreve } \\
\text { Vogal em Sílaba } \\
\text { de Contraste }\end{array}$ & $\begin{array}{l}\text { Coeficiente de } \\
\text { Correlação } \\
\text { Sig. }(2 \text { extremidades })\end{array}$ &,$- 425^{* *}$ & ,253 &, $712^{* *}$ & 1 \\
\hline
\end{tabular}

**. A correlação é significativa ao nível 0,01 (2 extremidade).

Com o teste de Rô Spearman encontramos uma forte correlação (Correlação de Rô Spearman 0,712; sig 0,01) entre utilizar as vogais pertinentemente em contexto de contraste e as utilizar em contexto não motivado. Ou seja, quem escreveu vogais em palavras de contraste também o fez em palavras não motivadas (Correlação de Rô Spearman 0,712; sig 0,0).

Em relação à utilização das consoantes, a métrica de Rô Spearman indica que é fraca a correlação com o nível de escrita, mesmo nas sílabas motivadas, o que quer dizer que o nível de escrita não interferiu na escolha entre usar consoante para representar o primeiro segmento silábico, como mostra a Tabela 35. 
Tabela 35: Correlação de Rô Sperman entre o nível de escrita e o total de utilização de consoantes em cada grupo de palavras $(n=48)$

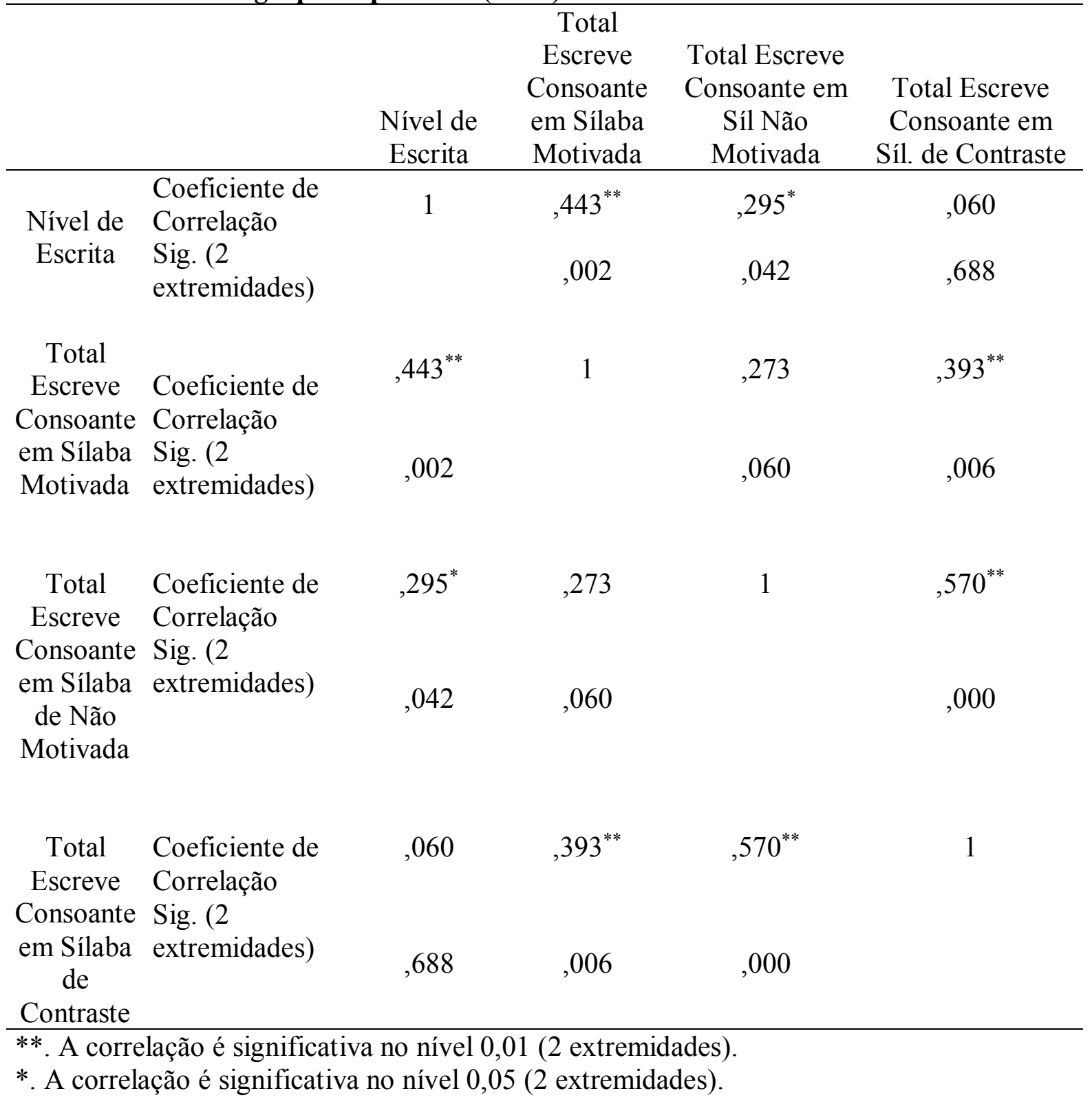

A correlação também foi fraca entre usar a consoante para escrever a sílaba motivada e poder usar a consoante para escrever a sílaba de contraste, e mais fraca ainda para escrever a sílaba não motivada.

Já quem pode usar a consoante para escrever sílabas de contraste, também pode usar consoantes para escrever as sílabas não motivadas. 


\subsubsection{Respostas Segundo a Posição Silábica}

Como a quantidade de respostas pertinentes para a $1^{\text {a }}$ sílaba foi alta, olhamos mais atentamente a pertinência com que as crianças escreveram as demais sílabas. A Tabela 36 mostra para cada sílaba - de acordo com a posição que ocupa na palavra - a frequência e a porcentagem, por nível de escrita, das respostas nas seguintes categorias: "Convencionais" (CV pertinentes), "Parcialmente convencionais" (consoante ou vogal pertinente), e "Não convencionais" (demais categorias: vogais e consoantes próximas fonologicamente ou não pertinentes).

Tabela 36: Frequência e porcentagem de respostas por posição silábica e nível de escrita

\begin{tabular}{|c|c|c|c|c|c|c|c|c|c|c|c|c|c|c|}
\hline & \multicolumn{4}{|c|}{ Convencional } & \multicolumn{4}{|c|}{ Parcialmente convencional } & \multicolumn{4}{|c|}{ Não convencional } & \multirow{2}{*}{$\begin{array}{c}\text { Total por } \\
\text { linha }\end{array}$} \\
\hline & & Total & SA & COM & SEM & Total & SA & COM & SEM & Total & SA & COM & SEM & \\
\hline \multirow{2}{*}{$1^{\circ}$ sílaba } & Frequência & 112 & 109 & 3 & 0 & 299 & 76 & 162 & 61 & 165 & 7 & 27 & 131 & 576 \\
\hline & \% no nível de escrita & $19 \%$ & $57 \%$ & $2 \%$ & $0 \%$ & $52 \%$ & $40 \%$ & $84 \%$ & $32 \%$ & $29 \%$ & $4 \%$ & $14 \%$ & $68 \%$ & $100 \%$ \\
\hline \multirow{2}{*}{$2^{\circ}$ sílaba } & Frequência & 111 & 104 & 7 & 0 & 287 & 83 & 166 & 38 & 178 & 5 & 19 & 154 & 576 \\
\hline & \% no nível de escrita & $19 \%$ & $54 \%$ & $4 \%$ & $0 \%$ & $50 \%$ & $43 \%$ & $86 \%$ & $20 \%$ & $31 \%$ & $3 \%$ & $10 \%$ & $80 \%$ & $100 \%$ \\
\hline \multirow{2}{*}{$3^{\circ}$ sílaba } & Frequência & 153 & 149 & 3 & 1 & 260 & 38 & 175 & 47 & 163 & 5 & 14 & 144 & 576 \\
\hline & \% no nível de escrita & $27 \%$ & $78 \%$ & $2 \%$ & $1 \%$ & $45 \%$ & $20 \%$ & $91 \%$ & $24 \%$ & $28 \%$ & $3 \%$ & $7 \%$ & $75 \%$ & $100 \%$ \\
\hline \multirow{2}{*}{ Total } & Frequência & 376 & 362 & 13 & 1 & 846 & 197 & 503 & 146 & 506 & 17 & 60 & 429 & 1728 \\
\hline & \% no nível de escrita & $22 \%$ & $63 \%$ & $2 \%$ & $0 \%$ & $49 \%$ & $34 \%$ & $87 \%$ & $25 \%$ & $29 \%$ & $3 \%$ & $10 \%$ & $74 \%$ & $100 \%$ \\
\hline
\end{tabular}

Das 1728 sílabas, distribuídas entre 12 palavras, escritas pelas 48 crianças que foram testadas, 22\% (376 casos) utilizaram escrita do tipo CV, 49\% (846 casos) utilizaram escrita silábica (atribuindo uma consoante ou uma vogal pertinente para representar a sílaba), e 29\% (506) utilizaram escrita não convencional.

Entre as respostas do tipo "Convencional", o resultado, como esperado, concentrou-se significativamente entre o grupo SA. Os grupos SCVC e SSVC não obtiveram resultados expressivos. A sílaba em que as crianças tiveram as melhores respostas foi a $3^{\mathrm{a}}$ sílaba $(78 \%$ de escrita $\mathrm{CV}$, entre o grupo SA), sendo que entre a $1^{\mathrm{a}}$ e a $2^{\mathrm{a}}$ não houve diferença relevante $(57 \%$ e $54 \%$, respectivamente).

Contudo, vale ressaltar que esse resultado não é significativo para identificar sobre qual posição silábica, em geral, a criança realiza maior análise, pois somente as primeiras sílabas de cada palavra foram selecionadas por critérios regulares, que permitem análise e comparação. Por exemplo, 1/3 das palavras testadas é iniciado por sílabas motivadas, e vimos nessa pesquisa o quanto esse tipo de palavra fez cair o "rendimento" das crianças do grupo SA. 
Entre as respostas "parcialmente convencionais", como esperado, o resultado concentrou-se no grupo SCVC (87\% ou 503 casos). As demais respostas estiveram distribuídas entre SA - 197 casos (34\%) e SSVC - 146 casos (25\%).

Para o grupo SCVC - mais representativo desse modo de representar a sílaba - esteve mais equilibrada a distribuição entre as sílabas, mas, apesar de pequenas discrepâncias, manteve-se o padrão do grupo SA na representação convencional: a última sílaba foi a mais representada por uma letra convencional apenas ou um "coringa" e a letra convencional (175 casos ou 91\% das respostas entre as crianças desse nível). Esse resultado é interessante, pois 1/3 das palavras testadas iniciou com sílaba motivada, o que poderia reforçar a presença desse tipo de resposta (parcialmente convencional) na $1^{\mathrm{a}}$ sílaba. O que mostra que a conceitualização influencia mais que a motivação fonológica.

No grupo SA, vimos que 76 casos $(40 \%$ das respostas do SA no grupo parcialmente convencional) escreveram apenas uma letra para o $1^{\circ}$ segmento; $43 \%$ das respostas utilizaram uma letra para o $2^{\circ}$ segmento, enquanto apenas $20 \%$, para o último. Tais dados são coerentes com o que observamos sobre as sílabas motivadas - que estas atrapalham o desempenho do SA para a escrita convencional -, uma vez que a primeira sílaba, nesse grupo, teve maior concentração de respostas tipicamente silábicas (uma letra para cada sílaba).

No grupo SA, decompomos as respostas parcialmente convencionais em consoante e em vogal e observamos que há uma expressiva quantidade de uso de consoantes para a $1^{\mathrm{a}}$ sílaba (54 casos de 61 casos possíveis, contra 7 vogais) - o que reforça a ideia de que as motivadas influenciariam o uso da consoante.

O grupo SSVSC - dado sua condição conceitual - teve um desempenho melhor na primeira sílaba, 61 casos ou 32\%; na 2a sílaba, 38 casos ou 20\%; e na última sílaba, 47 casos ou $24 \%$.

Entre as respostas "não convencionais", o resultado concentrou-se, como esperado, no grupo SVS, que deteve 74\% (429 casos). Segundo a distribuição das respostas, o grupo SSV teve menor quantidade de respostas não pertinentes na $1^{\mathrm{a}}$ sílaba, seguido pela última sílaba, sendo a $2^{\mathrm{a}}$ sílaba a que teve maior quantidade de respostas menos convencionais.

O grupo SCVSC escreveu mais sílabas não pertinentes na $1^{\mathrm{a}}$ sílaba (14\%), assim como o SA - apesar do resultado deste último ser pouco representativo (4\% da amostra - 7 casos apenas). 


\subsubsection{Síntese dos resultados na tarefa de escrita}

Por meio do nosso estudo, observamos que as crianças com escritas SSVSC foram as que tiveram probabilidade menor de representar pertinentemente um segmento silábico. Quando o fizeram, empregaram, sobretudo, vogais, porém, ao representar sílabas motivadas, usaram mais consoantes.

Igualmente, as crianças com escrita SCVSC preferiram as vogais para representar o primeiro segmento das palavras ditadas, porém, ao escreverem sílabas motivadas, usaram, sobretudo, consoantes.

Ao contrário das crianças com escritas SSVSC e SCVSC, as respostas pertinentes das crianças SA foram escritas majoritariamente com a CV pertinente. Quando não o fizeram, optaram pela consoante para a representação da sílaba. Observando no interior dos grupos de palavras, as sílabas motivadas foram representadas de maneira silábica por meio do uso de uma consoante, e nas de "contraste" e "não motivadas" houve incremento das respostas convencionais (CV pertinente) dos segmentos iniciais.

Embora seja certo que a motivação das sílabas iniciais pode fazer com que as crianças empreguem a consoante correspondente de maneira pertinente em sua representação, o esquema silábico condicionou que o uso que se fez desta consoante fosse igualmente silábico. Isto poderia nos levar a concluir sobre a utilidade dos segmentos motivados, embora a referida utilidade só tenha se apresentado entre as crianças com escritas SSVSC e SCVSC. Para as crianças com escritas mais avançadas, a utilidade do contraste que conseguiram fazer entre o nome da letra e os segmentos não motivados foi maior, levando-as, inclusive, a apresentar respostas convencionais. Esta consideração é importante porque relativiza o efeito da motivação ligado ao nome das letras, porque nem sempre a motivação esteve relacionada ao maior ou menor êxito.

As crianças se mostraram sensíveis aos segmentos motivados e provavelmente por isso usaram as consoantes pertinentes, mas o fizeram dentro de representações silábicas, o que nos permite argumentar sobre o que define a análise que fazem do funcionamento do sistema de escrita. Suas respostas não foram apenas produtos da informação externa (os nomes das letras), mas estiveram condicionadas pela interpretação que construíram sobre o sistema (uma interpretação silábica).

A informação sobre o nome das letras motivada foi útil, mas só em segmentos motivados, nos demais, as crianças sentiram-se mais à vontade usando as vogais. 
As respostas das crianças mostram que elas conhecem as vogais e as consoantes, porém, a coordenação das informações ainda está longe de suas possibilidades. As crianças com escritas SA foram as que mais obtiveram êxito nesse sentido.

Nesta tarefa, tanto as sílabas de contraste quanto as motivadas se iniciavam com a mesma consoante, variando apenas o núcleo silábico. Apesar das crianças terem utilizado pertinentemente a consoante no contexto motivado, ao terem que escrever uma sílaba com a mesma consoante em contexto não motivado (contraste), preferiram utilizar a vogal. Esse dado nos permite avaliar que a motivação fonológica influenciou as decisões que as crianças tomaram ao escolherem entre usar vogais ou consoantes para escrever. Porém, escolher entre a consoante pertinente e a vogal pertinente não implica uma diferença de natureza qualitativa. São respostas igualmente pertinentes.

Os dados também indicam que essa influência não foi igual nos diferentes níveis de escrita. Analisando as respostas consideradas pertinentes, as crianças SSVSC e SCVSC utilizaram mais consoantes em contexto motivado, e em contextos não motivados (incluídos os de contraste) utilizaram mais vogais. Já as crianças com nível conceitual mais avançado (SA), nos contextos não motivados, escreveram majoritariamente a sílaba de forma convencional, e, ao escreverem em contextos motivados, utilizaram somente a consoante, evidenciando que para as crianças desse nível o contexto motivado, ao contrário, não foi um facilitador.

Independentemente da motivação fonológica, observamos que o índice de acertos esteve totalmente relacionado ao nível de escrita: quanto mais avançada a conceitualização, mais pertinente é a escrita apresentada.

\subsection{Análise da tarefa de identificação de letras fora do contexto}

Na tarefa de identificação de letras fora de contexto mostramos às crianças uma folha em branco que continha as letras do alfabeto distribuídas aleatoriamente. As crianças deveriam dizer, se soubessem, qual era a letra que o entrevistador assinalava. As respostas das crianças foram organizadas nas seguintes categorias:

a. Nomear convencionalmente: as crianças identificaram a letra com seu nome convencional, por exemplo, diante da letra "G", disseram "gê";

b. Aludir a um fonema: as crianças mencionaram o fonema convencional que representava a letra apontada. Por exemplo, diante da letra "B", disseram /b/;

c. Aludir ao contexto silábico: as crianças identificaram a letra por meio de uma sílaba que a continha, por exemplo, diante da letra "F", disseram "é a /fa/"; 
d. Aludir ao início da palavra: as crianças identificaram a letra dando como referente uma palavra que a continha no início. Por exemplo: diante da letra "M", disseram "é a da mamãe";

e. Aludir a palavra sem considerar o início: as crianças identificaram a letra dando como referente uma palavra que a continha, mas não no início. Por exemplo, diante da letra "Z", disseram "azul";

f. Não identificar a letra: as crianças, diante da letra, referiram não saber qual era, não oferecendo nenhum tipo de resposta ou a relacionaram de acordo com sua forma - "a cobrinha" - ou com números - "o dois";

g. Outra letra sem relação: as crianças identificaram como letras, mas referiram seus nomes aleatoriamente, por exemplo, diante da letra "C", referiram "é a /jota/".

Essas sete categorias de respostas foram reagrupadas de forma resumida em dois grupos. Um que reuniu as respostas pertinentes (que aludem ao nome convencional ou a um contexto silábico ou fonológico no qual a letra apresentada corresponde efetivamente ao segmento aludido) e outro que continha as respostas não pertinentes (que aludem a uma palavra sem considerar o início ou nomear a letra sem qualquer relação, ou, ainda, não realizar qualquer nomeação). A Tabela 37 resume o agrupamento realizado.

Tabela 37: Categorias de análise para as respostas encontradas na tarefa de identificação de letras

\begin{tabular}{ll}
\hline Respostas pertinentes & Respostas não pertinentes \\
\hline Alude ao nome convencional & Não identifica a letra \\
Alude a um fonema & Outra letra sem relação \\
Alude ao contexto silábico & \\
Alude ao início da palavra & \\
Alude a palavra sem considerar o & \\
Início & \\
\hline
\end{tabular}

Ao organizarmos as respostas nesses dois grupos notamos que as crianças da amostra possuíam amplo conhecimento sobre o nome das letras: 71,8\% (827 casos) de respostas pertinentes, diante de 26,56\% (306 casos) de respostas não pertinentes. (Ntotal= número de letras x número de crianças $=1152$ ). Na Tabela 38, a seguir, encontramos a distribuição dessas respostas nas diferentes categorias. 
Tabela 38: Frequência e porcentagem de acordo com as categorias de respostas em geral

\begin{tabular}{clcccccccc}
\hline & & $\begin{array}{c}\text { Nome } \\
\text { conve } \\
\text { nciona } \\
\text { I }\end{array}$ & $\begin{array}{c}\text { Alude a } \\
\text { um } \\
\text { fonema }\end{array}$ & $\begin{array}{c}\text { Alude ao } \\
\text { contexto } \\
\text { silábico }\end{array}$ & $\begin{array}{c}\text { Alude o } \\
\text { ińcio } \\
\text { de } \\
\text { palavra }\end{array}$ & $\begin{array}{c}\text { Palavra } \\
\text { sem } \\
\text { considerar } \\
\text { o início }\end{array}$ & $\begin{array}{c}\text { Não } \\
\text { ident } \\
\text { letra }\end{array}$ & $\begin{array}{c}\text { Letra } \\
\text { não } \\
\text { pert. }\end{array}$ & $\begin{array}{c}\text { Total } \\
\text { por } \\
\text { linha }\end{array}$ \\
\hline \hline \multirow{2}{*}{ Vogais } & $\begin{array}{l}\text { Frequência } \\
\text { Porcentagem }\end{array}$ & 203 & 0 & 0 & 2 & 1 & 14 & 20 & 240 \\
& & 84,58 & 0,00 & 0,00 & 0,83 & 0,42 & 5,83 & 8,33 & 100 \\
& & & & & & & & \\
Consoantes & Frequência & 624 & 0 & 2 & 12 & 2 & 182 & 90 & 912 \\
& Porcentagem & 68,42 & 0,00 & 0,22 & 1,32 & 0,22 & 19,96 & 9,87 & 100 \\
\hline Total de & Frequência & 827 & 0 & 2 & 14 & 3 & 196 & 110 & 1152 \\
respostas & Porcentagem & 71,79 & 0,00 & 0,17 & 1,22 & 0,26 & 17,01 & 9,55 & 100 \\
\hline
\end{tabular}

Entre as categorias pertinentes, as respostas se concentraram de modo significativo no nome convencional da letra (71.79\%). Já entre as categorias não pertinentes, a distribuição das respostas foi mais equilibrada: $17 \%$ não identificaram e 9,55\% identificaram letra não pertinente.

Embora as crianças possam identificar muitas letras, não foi equivalente a identificação das letras que representam vogais ( $85 \%$ de acertos) e a das que representam consoantes $(70,18 \%$ de acertos). Ao aplicarmos o Test $T$ de Student observamos que a diferença entre o índice de reconhecimento de vogais e consoantes é estatisticamente relevante $(\mathrm{T}=0,178)$. Portanto, podemos afirmar que identificar vogais foi uma tarefa mais simples que identificar consoantes, como podemos observar na Tabela 39:

\section{Tabela 39: Frequências e porcentagens de respostas pertinentes e não pertinentes}

\begin{tabular}{clcc}
\hline & Pertinente & $\begin{array}{c}\text { Não } \\
\text { pertinente }\end{array}$ \\
\hline $\begin{array}{c}\text { Vogais } \\
(\mathrm{n}=240)\end{array}$ & Frequência & 206 & 34 \\
& Porcentagem & 85,83 & 14,17 \\
$\begin{array}{c}\text { Consoantes } \\
(\mathrm{n}=912)\end{array}$ & Frequência & 640 & 272 \\
\hline $\begin{array}{c}\text { Total de } \\
\text { respostas } \\
(\mathrm{n}=1152)\end{array}$ & Frequência & 846 & 306 \\
\hline
\end{tabular}

Em relação às vogais, apesar dos resultados terem se concentrado na nomeação convencional, apontando que as crianças as reconhecem, entre elas o comportamento de cada uma não foi igual. Pode-se observar que a letra "A" foi a mais identificada e a "E" a menos, 
com uma diferença significativa de $23 \%$ entre elas. Os resultados para cada vogal estão expressos na Tabela 40.

Tabela 40: Frequências e Porcentagens de respostas de vogais pertinentes e não pertinentes

\begin{tabular}{clcc}
\hline & & Pertinente & $\begin{array}{c}\text { Não } \\
\text { pertinente }\end{array}$ \\
\hline & Frequência & 47,0 & 1,0 \\
A & Porcentagem & 97,9 & 2,1 \\
& & & \\
& Frequência & 42,0 & 6,0 \\
O & Porcentagem & 87,5 & 12,5 \\
& & & \\
& Frequência & 41,0 & 7,0 \\
& Porcentagem & 85,4 & 14,6 \\
& & & \\
& Frequência & 40,0 & 8,0 \\
& Porcentagem & 83,3 & 16,7 \\
& & & \\
& Frequência & 36,0 & 12,0 \\
E & Porcentagem & 75,0 & 25,0 \\
\hline \multirow{2}{*}{ Total de respostas } & Frequência & 206,0 & 34,0 \\
& Porcentagem & 85,8 & 14,2 \\
\hline
\end{tabular}

Se compararmos a frequência de vogais identificadas pelas crianças e a frequência de uso das vogais no português (Quaresma \& Pinho, 2007), podemos notar que somente a letra "A" poderia ser justificada como sendo a mais identificada pelas crianças pelo fato de ser a de maior ocorrência no português. Contudo, as demais vogais se comportam de modo muito diferente: a letra "E", por exemplo, que é a segunda mais utilizada, foi a menos reconhecida pelas crianças; a letra "O”, que ocupa uma posição intermediária em relação à aparição das vogais no português, foi a segunda mais identificada pelas crianças. Estas diferenças permitem levantar a hipótese de que as frequências de aparição da letra em contextos sociais não influenciaram a identificação das letras isoladamente. Vejamos a Figura 9: 


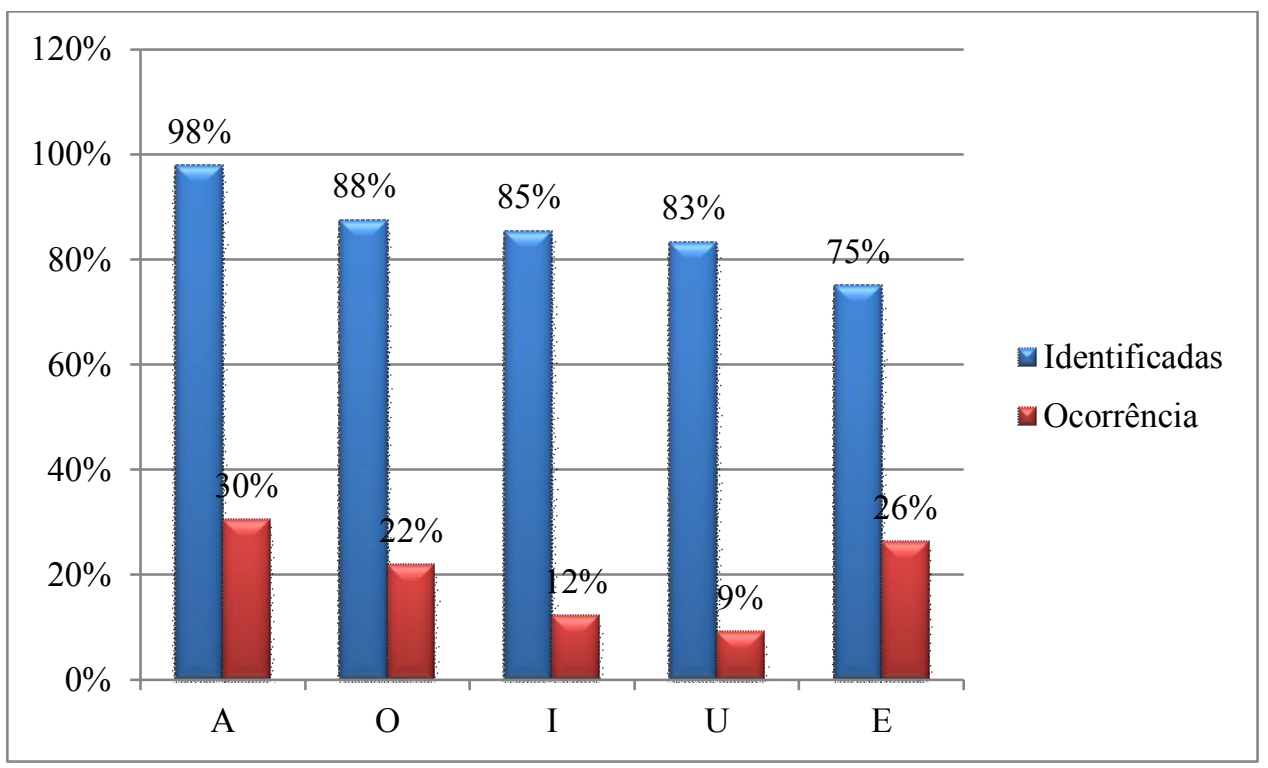

Figura 5 Porcentagens de vogais identificadas e sua ocorrência no português

Em relação ao reconhecimento das consoantes por parte dos sujeitos pesquisados, observa-se o mesmo comportamento, pois a maioria das respostas também foi pertinente (70,18\%), diante de $29,82 \%$ que foram "não pertinentes". Isso nos permite afirmar que as crianças, de modo geral, conhecem também as consoantes (Tabela 39).

Contudo, as consoantes não se comportaram de maneira equivalente entre si. Como podemos observar na Tabela 41, a letra $\mathrm{X}$ teve maior índice de acerto e a $\mathrm{K}$, menor índice.

Tabela 41: Frequências e porcentagens de respostas de consoantes pertinentes e não pertinentes $(\mathbf{n}=912)$

\begin{tabular}{cccccccc}
\hline LETRA & Pertinente & LETRA & Pertinente & LETRA & Pertinente & LETRA & Pertinente \\
\hline & 42 & & 36 & & 32 & & 29 \\
$\mathbf{X}$ & $88 \%$ & $\mathbf{S}$ & $75 \%$ & $\mathbf{G}$ & $67 \%$ & $\mathbf{C}$ & $60 \%$ \\
& 40 & & 36 & & 32 & & 29 \\
$\mathbf{B}$ & $83 \%$ & $\mathbf{T}$ & $75 \%$ & $\mathbf{J}$ & $67 \%$ & $\mathbf{Z}$ & $60 \%$ \\
& 38 & & 35 & & 32 & & 28 \\
$\mathbf{H}$ & $79 \%$ & $\mathbf{N}$ & $73 \%$ & $\mathbf{Q}$ & $67 \%$ & $\mathbf{F}$ & $58 \%$ \\
& 37 & & 35 & & 31 & & 26 \\
$\mathbf{L}$ & $77 \%$ & $\mathbf{V}$ & $73 \%$ & $\mathbf{D}$ & $65 \%$ & $\mathbf{K}$ & $54 \%$ \\
& 37 & & 34 & & 31 & & \\
$\mathbf{R}$ & $77 \%$ & $\mathbf{M}$ & $71 \%$ & $\mathbf{P}$ & $65 \%$ & & \\
\hline
\end{tabular}


Se compararmos a frequência de consoantes identificadas pelas crianças e a frequência de uso dessas mesmas consoantes no português (Quaresma \& Pinho, 2007), a conclusão é bastante semelhante ao observado no comportamento das vogais. Vejamos a Figura 6:

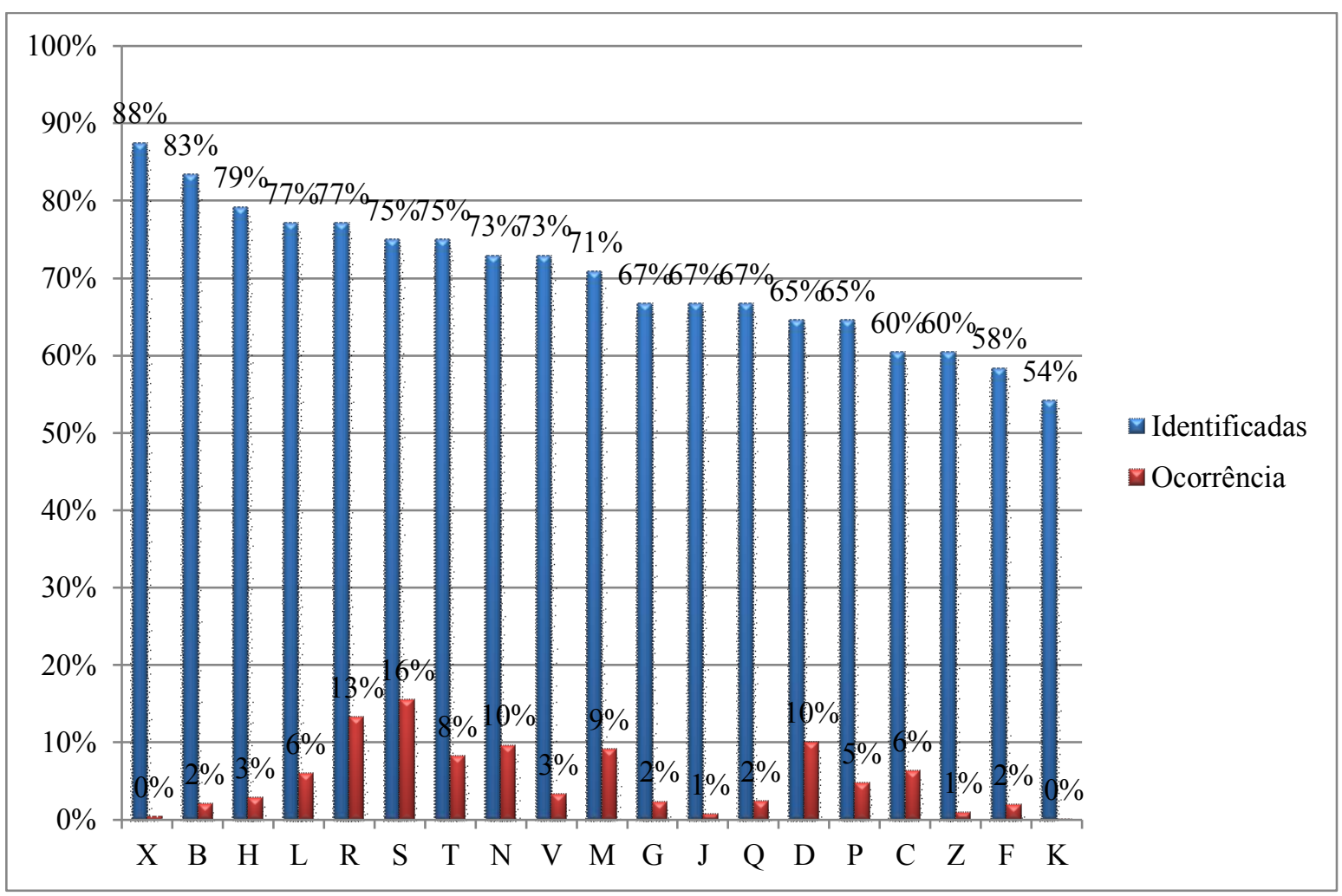

Figura 6 Porcentagens de consoantes identificadas e sua ocorrência no português

Há um comportamento muito diferente nas duas frequências observadas, levando a crer que não haja relação entre a letra ter maior frequência na língua e ser mais facilmente identificável pela criança. A letra X é um exemplo claro disso, pois, entre as consoantes analisadas, é a que tem menos frequência de aparição no português, contudo, foi a mais identificada pelas crianças.

Uma ressalva, porém, se faz necessária. $\mathrm{O}$ cálculo da frequência das letras implica a seleção de materiais escritos de circulação social. A depender do gênero, estilo narrativo, vocabulário específico, entre outros, isso resulta na aparição de mais letras que outras. Além disso, os textos utilizados para análises dessa natureza normalmente não incluem produções destinadas ao público infantil, que são os sujeitos dessa pesquisa. 


\subsubsection{Análise segundo motivação fonológica da letra}

Continuando a análise a partir da identificação das consoantes, organizamos esse grupo de letras em dois subgrupos - (1) aquelas que são motivadas fonologicamente, ou seja, aquelas cujo nome coincide com o respectivo fonema; (2) não motivadas fonologicamente, aquelas cujo nome não coincide com o respectivo fonema. Deixamos de fora dessa análise três letras que poderiam gerar confusão em relação à definição de sua motivação fonológica. Foram elas:

Tabela 42: Agrupamentos de consoantes segundo motivação fonológica

\begin{tabular}{ccc}
$\begin{array}{c}\text { Letras } \\
\text { motivadas } \\
\text { fonologicamente }\end{array}$ & $\begin{array}{c}\text { Letras não } \\
\text { motivadas }\end{array}$ & $\begin{array}{c}\text { Letras não } \\
\text { analisadas }\end{array}$ \\
\hline $\mathrm{B}$ & $\mathrm{F}$ & $\mathrm{H}$ \\
$\mathrm{C}$ & $\mathrm{J}$ & $\mathrm{K}$ \\
$\mathrm{D}$ & $\mathrm{L}$ & $\mathrm{Q}$ \\
$\mathrm{G}$ & $\mathrm{M}$ & \\
$\mathrm{P}$ & $\mathrm{N}$ & \\
$\mathrm{T}$ & $\mathrm{R}$ & \\
$\mathrm{V}$ & $\mathrm{S}$ & \\
$\mathrm{Z}$ & $\mathrm{X}$ & \\
\hline
\end{tabular}

Ao realizarmos uma análise sobre os totais, observamos que as letras não motivadas tiveram $73 \%$ ( $\mathrm{f}=281)$ de acertos enquanto as motivadas tiveram $68 \%(\mathrm{f}=263)$ de acertos. Apesar de os resultados serem aparentemente equivalentes, a comparação por meio do Test $T$ apontou que os resultados são estatisticamente discrepantes, ou seja, a diferença de 5\% entre um e outro é significativa e sinaliza que identificar as não motivadas foi mais fácil que identificar as motivadas $(\mathrm{T}=0,195)$.

Tabela 43: Frequência e porcentagem de consoantes identificadas segundo a motivação fonológica $(n=768)$

\begin{tabular}{clccc}
\hline & & & $\begin{array}{c}\text { Não } \\
\text { Pertinente }\end{array}$ & $\begin{array}{c}\text { Totais por } \\
\text { Pertinente }\end{array}$ \\
\hline \multirow{2}{*}{ linhativadas } & $\begin{array}{l}\text { Frequência } \\
\text { Porcentagem }\end{array}$ & 263 & 121 & 384 \\
& & $68 \%$ & $32 \%$ & $100 \%$ \\
Não motivadas & Frequência & 281 & 103 & 384 \\
& Porcentagem & $73 \%$ & $27 \%$ & $100 \%$ \\
\hline \multirow{2}{*}{ Total de respostas } & $\begin{array}{c}\text { Frequência } \\
\text { Porcentagem }\end{array}$ & 544 & 224 & 768 \\
& & $71 \%$ & $29 \%$ & $100 \%$ \\
\hline
\end{tabular}


Se por um lado as vogais, que são manifestações fonológicas com a maior motivação letra/som possível, foram as mais identificadas, por outro, as consoantes, que possuem semelhante grau de motivação (consoantes motivadas), não representaram maior facilidade de reconhecimento diante das demais letras, não motivadas.

As letras não motivadas compartilham outra característica fonológica, que é a possibilidade fonética de prolongamento, ou seja, são letras que representam fonemas prolongáveis durante a emissão oral (fonemas mais contínuos). Esses achados estão de acordo com o que foi apontando por Fernández (2015), que, ao analisar as produções de crianças cuja língua materna é o espanhol, identificou que o traço de continuidade (ser relativo a um fonema prolongável) é uma característica relevante que facilita o reconhecimento da letra e sua possibilidade de uso em outros contextos.

\subsubsection{Análise Por Nível de Escrita}

Ao relacionarmos a identificação de letras com o nível de escrita, os resultados sugerem que essas variáveis são diretamente associadas: quanto mais avançado o nível de escrita, maior a possibilidade de reconhecimento de letras. Como mostra a Tabela 44:

Tabela 44: Frequências e porcentagens de respostas pertinentes na tarefa de identificação de letras fora do contexto, por nível de escrita

\begin{tabular}{clcc}
\hline & & Vogal & Consoante \\
\hline \multirow{2}{*}{ SSVSC } & Frequência & 54 & 140 \\
& Porcentagem & 67,5 & 46,1 \\
\multirow{2}{*}{ SCVSC } & Frequência & 72 & 209 \\
& Porcentagem & 90,0 & 68,8 \\
\multirow{2}{*}{ SA } & Frequência & 80 & 291 \\
& Porcentagem & 100,0 & 95,7 \\
\hline \multirow{2}{*}{ Total de respostas } & Frequência & 206 & 640 \\
& Porcentagem & 85,8 & 70,2 \\
\hline
\end{tabular}

As diferenças são estatisticamente significativas entre SSVSC e SCVSC, assim como entre SSVSC e SA e SCVSC e SA. Tanto para vogal quanto para consoantes, o Teste $T$ de Student apontou valores menores ou iguais a 0,01 . 
Para verificar se a correlação entre o nível de escrita e a identificação de letras era estatisticamente relevante utilizamos a Correlação de Rô de Spearman. A Tabela 45 mostra o alto nível de correlação bilateral por meio do teste.

Tabela 45: Correlação de $\boldsymbol{R} \hat{o}$ de Spearman entre Identificação de vogais e consoantes e o nível de escrita

\begin{tabular}{|c|c|c|c|c|}
\hline & & $\begin{array}{l}\text { Nível de } \\
\text { escrita }\end{array}$ & $\begin{array}{c}\text { Total } \\
\text { Identifica } \\
\text { Vogais } \\
\end{array}$ & $\begin{array}{c}\text { Total } \\
\text { Identifica } \\
\text { Consoantes }\end{array}$ \\
\hline \multirow{2}{*}{ Nível de escrita } & \multirow{2}{*}{$\begin{array}{l}\text { Correlações de Coeficiente } \\
\text { Sig. (2 extremidades) }\end{array}$} & \multirow[t]{2}{*}{1} & $0,643 * *$ & $0,679 * *$ \\
\hline & & & 0,00 & 0,00 \\
\hline \multirow{2}{*}{$\begin{array}{l}\text { Total Identifica } \\
\text { Vogais }\end{array}$} & \multirow{2}{*}{$\begin{array}{l}\text { Correlações de Coeficiente } \\
\text { Sig. ( } 2 \text { extremidades) }\end{array}$} & $0,643 * *$ & \multirow[t]{2}{*}{1} & $0,767 * *$ \\
\hline & & 0,00 & & 0,00 \\
\hline \multirow{2}{*}{$\begin{array}{l}\text { Total Identifica } \\
\text { Consoantes }\end{array}$} & \multirow{2}{*}{$\begin{array}{l}\text { Correlações de Coeficiente } \\
\text { Sig. ( } 2 \text { extremidades) }\end{array}$} & $0,679 * *$ & $0,767 * *$ & \multirow[t]{2}{*}{1,00} \\
\hline & & 0,00 & 0,00 & \\
\hline
\end{tabular}

Os dados acima apontam uma correlação significativa entre identificar letras e o nível de escrita.

\subsubsection{Identificação de vogais por nível de escrita}

Ao observar as porcentagens percebemos que as crianças, independentemente do nível de escrita, tiveram mais êxito ao identificar as vogais, e que a quantidade de respostas pertinentes foi maior quanto mais avançado o nível de escrita.

De modo geral, a identificação de vogais teve relação com o nível de escrita $\left(X^{2}=24.032\right.$; $\mathrm{p}=.003, \mathrm{p}<.05$ ). Contudo, como vemos na Tabela 46, essa relação não foi equivalente para todas as vogais. 
Tabela 46: Resumo dos Testes de Chi-Quadrada de acordo com a vogal

\begin{tabular}{cccc}
\hline Letra & Valor & gl & $\begin{array}{c}\text { Sig.Asintotica } \\
\text { (bilateral) }\end{array}$ \\
\hline A & 2,043 & 2 & 0,36 \\
E & 4,571 & 2 & 0,102 \\
I & 10,667 & 2 & 0,005 \\
O & 16,39 & 2 & 0 \\
U & 18,87 & 2 & 0,002 \\
\hline
\end{tabular}

A identificação de "A" e "O" não esteve estatisticamente relacionada com o nível de escrita, já que praticamente todas as crianças identificaram " $\mathrm{A}$ ” $(97,92 \%)$, e "O" foi identificado de maneira mais ou menos equivalente entre as crianças, sem poder estabelecer maior preponderância de algum grupo por seu nível de escrita.

\subsubsection{Identificação de consoantes por nível de escrita}

Como demonstrado na linha "total de respostas" da Tabela 47, existe uma relação direta e proporcional entre a porcentagem de respostas corretas e o nível de escrita. Ou seja, conforme avança o nível de escrita, as crianças apresentam porcentagens mais altas de respostas corretas para a identificação de consoantes.

Tabela 47: Frequência e porcentagem de respostas corretas por tipo de consoante (motivada e não motivada ${ }^{28}$ ) e nível de escrita

SSVSC SCVSC SA Total

\begin{tabular}{cccccc}
\hline \multirow{2}{*}{ Motivadas } & Frequência & 51 & 86 & 126 & 263 \\
& Porcentagem & 39,8 & 67,2 & 98,4 & 68,49 \\
& & & & & \\
\multirow{2}{*}{ Não Motivadas } & Frequência & 69 & 89 & 123 & 281 \\
& Porcentagem & 53,9 & 69,5 & 96,1 & 73,18 \\
\hline \multirow{2}{*}{ Total de } & Frequência & 120 & 175 & 249 & 544 \\
respostas & Porcentagem & 46,9 & 68,4 & 97,3 & 70,8 \\
\hline
\end{tabular}

${ }^{28}$ Ver Tabela 42 
De modo geral, a identificação de consoantes motivadas teve relação com o nível de escrita $\left(X^{2}=26.892 ; \alpha .002\right)$, e esta relação foi equivalente para todas as letras, embora a letra $Z$ seja a que parece ter maior relação com o nível de escrita.

\section{Tabela 48: Resumo dos Testes de Qui-Quadrada de acordo com a consonante motivada}

\begin{tabular}{cccc}
\hline Letra & Valor & gl & $\begin{array}{c}\text { Sig. } \\
\text { Asintotica } \\
\text { (bilateral) }\end{array}$ \\
\hline Z & $25,371 \mathrm{a}$ & 2 & 0 \\
$\mathrm{D}$ & $19,856 \mathrm{a}$ & 2 & 0 \\
$\mathrm{~B}$ & $19,2 \mathrm{a}$ & 2 & 0 \\
$\mathrm{G}$ & $14,250 \mathrm{a}$ & 2 & 0,001 \\
$\mathrm{C}$ & $11,673 \mathrm{a}$ & 2 & 0,03 \\
$\mathrm{~V}$ & $11,055 \mathrm{a}$ & 2 & 0,0054 \\
$\mathrm{~T}$ & $10,677 \mathrm{a}$ & 2 & 0,005 \\
$\mathrm{P}$ & $9,472 \mathrm{a}$ & 2 & 0,009 \\
\hline
\end{tabular}

As respostas dadas às consoantes não motivadas também mostraram-se estatisticamente relacionadas com o nível de escrita $\left(X^{2}=25.395 ; \alpha .001\right)$, e essa relação, como mostra a Tabela 49 , foi equivalente para todas as letras, ainda que a letra $X$, a consoante mais identificada, pareça não ter seu índice de acerto relacionado com o nível de escrita.

Tabela 49: Resumo dos resultados dos testes de Qui-Quadrado para respostas corretas de cada consoante não motivada

\begin{tabular}{cccc}
\hline Letra & Valor & gl & $\begin{array}{c}\text { Sig. } \\
\text { Asintotica } \\
\text { (bilateral) }\end{array}$ \\
\hline J & $12,563 \mathrm{a}$ & 2 & 0,002 \\
$\mathrm{M}$ & $11,055 \mathrm{a}$ & 2 & 0,004 \\
$\mathrm{~S}$ & $10,667 \mathrm{a}$ & 2 & 0,005 \\
$\mathrm{~F}$ & $10,457 \mathrm{a}$ & 2 & 0,005 \\
$\mathrm{~N}$ & $10,338 \mathrm{a}$ & 2 & 0,006 \\
$\mathrm{~L}$ & $8,727 \mathrm{a}$ & 2 & 0,013 \\
$\mathrm{R}$ & $8,727 \mathrm{a}$ & 2 & 0,013 \\
$\mathrm{X}$ & $1,143 \mathrm{a}$ & 2 & 0,565 \\
\hline
\end{tabular}




\subsubsection{Síntese dos resultados da tarefa de identificação de letras}

A análise dos resultados da tarefa de identificação de letras evidenciou que as crianças têm muito conhecimento sobre os nomes das letras.

As vogais, de modo geral, tiveram uma porcentagem alta de acerto $(85,83 \%)$, mas entre elas foi possível observar diferenças: a letra " $A$ " foi a mais reconhecida $(97,92 \%)$ e a "E" foi a menos reconhecida $(75 \%)$.

$\mathrm{Na}$ análise por nível de escrita vimos que, de modo geral, a identificação das vogais esteve relacionada com a conceitualização: quanto mais avançado, maior a frequência de acerto. Contudo, essa relação não foi equivalente para todas as vogais, já que tanto o reconhecimento da vogal "A" quanto da vogal "O" não estiveram estatisticamente relacionados com o nível de escrita.

A identificação das consoantes também esteve relacionada com o nível de escrita, tanto para as motivadas quanto para as não motivadas. Contudo, revelou-se que estatisticamente não é o mesmo identificar letras motivadas e letras não motivadas, sendo que as últimas foram mais frequentemente identificadas de forma pertinente.

Portanto, a tarefa de identificar letras permitiu concluir que, conforme se incrementa o nível de conceitualização sobre o sistema de escrita, aumenta a possibilidade de reconhecer o nome das letras apresentadas, ou seja, a possibilidade de identificação de letras está condicionada pela reflexão que a criança faz do sistema de escrita, como também pelas características relacionadas à motivação fonológica.

Apesar de intuitivamente parecer mais fácil identificar as letras cujos nomes coincidem com os respectivos fonemas que representam - por exemplo, a letra $\mathrm{T}$ chama-se "te" $\mathrm{e}$ pronuncia-se /t/ - os dados levantados e analisados nesta pesquisa permitem concluir que as letras que não apresentam motivação fonológica foram mais frequentemente identificadas. Ou seja, a motivação fonológica não foi um fator que influenciou a identificação das letras correspondentes.

\subsection{Análise da tarefa de completar palavras}

Na tarefa de completar palavras, mostramos uma folha com uma palavra escrita em que faltava a primeira letra e um lista de opções de letras que serviria para completar a respectiva palavra. Solicitávamos, então, que a criança selecionasse a letra que completaria adequadamente a palavra, e a lesse em voz alta. 
As opções incluíam a letra alvo, a vogal que compunha a sílaba, outra vogal, uma consoante fonologicamente próxima e uma consoante fonologicamente distante. Já as palavras, apesar de serem apresentadas individualmente em cada folha, faziam parte de três grupos: (1) palavras cujas sílabas iniciais eram motivadas fonologicamente; (2) palavras cujas sílabas iniciais faziam contraste; e (3) palavras cujas sílabas iniciais não eram motivadas.

A análise dos resultados, de modo global, nos permitiu verificar que pouco mais da metade da amostra, 54,17\% (312 casos), respondeu de modo convencional, ou seja, selecionaram corretamente a respectiva consoante. Em seguida, com 26,56\% (153 casos) das respostas, a escolha foi pela vogal que compõe a sílaba. As demais respostas se distribuíram entre selecionar outra vogal, uma consoante fonologicamente próxima ou uma consoante fonologicamente distante.

Na Tabela 50, podemos observar a distribuição das respostas de acordo com as palavras trabalhadas e as categorias de análise. 
Tabela 50: Frequência e Porcentagem de respostas obtidas por palavra

\begin{tabular}{|c|c|c|c|c|c|c|c|}
\hline Palavra & & Letra alvo & $\begin{array}{c}\text { Vogal que } \\
\text { compõe a } \\
\text { sílaba }\end{array}$ & $\begin{array}{l}\text { Outra } \\
\text { Vogal }\end{array}$ & $\begin{array}{c}\text { Próxima } \\
\text { fonologicamente }\end{array}$ & Distante & $\begin{array}{l}\text { Total } \\
\text { por } \\
\text { linha }\end{array}$ \\
\hline BECO & $\begin{array}{l}\text { Frequência } \\
\text { Porcentagem }\end{array}$ & $\begin{array}{c}37 \\
77,08\end{array}$ & $\begin{array}{c}2 \\
4,17\end{array}$ & $\begin{array}{c}0 \\
0,00\end{array}$ & $\begin{array}{c}6 \\
12,50\end{array}$ & $\begin{array}{c}3 \\
6,25\end{array}$ & $\begin{array}{c}48 \\
100\end{array}$ \\
\hline VEJO & $\begin{array}{l}\text { Frequência } \\
\text { Porcentagem }\end{array}$ & $\begin{array}{c}36 \\
75,00\end{array}$ & $\begin{array}{c}5 \\
10,42\end{array}$ & $\begin{array}{c}0 \\
0,00\end{array}$ & $\begin{array}{c}5 \\
10,42\end{array}$ & $\begin{array}{c}2 \\
4,17\end{array}$ & $\begin{array}{c}48 \\
100\end{array}$ \\
\hline TEMA & $\begin{array}{l}\text { Frequência } \\
\text { Porcentagem }\end{array}$ & $\begin{array}{c}34 \\
70,83\end{array}$ & $\begin{array}{c}7 \\
14,58\end{array}$ & $\begin{array}{c}0 \\
0,00\end{array}$ & $\begin{array}{c}7 \\
14,58\end{array}$ & $\begin{array}{c}0 \\
0,00\end{array}$ & $\begin{array}{c}48 \\
100\end{array}$ \\
\hline PENA & $\begin{array}{l}\text { Frequência } \\
\text { Porcentagem }\end{array}$ & $\begin{array}{c}34 \\
70,83\end{array}$ & $\begin{array}{c}5 \\
10,42\end{array}$ & $\begin{array}{c}0 \\
0,00\end{array}$ & $\begin{array}{c}6 \\
12,50\end{array}$ & $\begin{array}{c}3 \\
6,25\end{array}$ & $\begin{array}{c}48 \\
100\end{array}$ \\
\hline VILA & $\begin{array}{l}\text { Frequência } \\
\text { Porcentagem }\end{array}$ & $\begin{array}{c}28 \\
58,33\end{array}$ & $\begin{array}{c}11 \\
22,92\end{array}$ & $\begin{array}{c}0 \\
0,00\end{array}$ & $\begin{array}{c}8 \\
16,67\end{array}$ & $\begin{array}{c}1 \\
2,08\end{array}$ & $\begin{array}{c}48 \\
100\end{array}$ \\
\hline TOMA & $\begin{array}{l}\text { Frequência } \\
\text { Porcentagem }\end{array}$ & $\begin{array}{c}25 \\
52,08\end{array}$ & $\begin{array}{c}16 \\
33,33\end{array}$ & $\begin{array}{c}1 \\
2,08\end{array}$ & $\begin{array}{c}4 \\
8,33\end{array}$ & $\begin{array}{c}2 \\
4,17\end{array}$ & $\begin{array}{c}48 \\
100\end{array}$ \\
\hline BOCA & $\begin{array}{l}\text { Frequência } \\
\text { Porcentagem }\end{array}$ & $\begin{array}{c}25 \\
52,08\end{array}$ & $\begin{array}{c}18 \\
37,50\end{array}$ & $\begin{array}{c}0 \\
0,00\end{array}$ & $\begin{array}{c}3 \\
6,25\end{array}$ & $\begin{array}{c}2 \\
4,17\end{array}$ & $\begin{array}{c}48 \\
100\end{array}$ \\
\hline LIMA & $\begin{array}{l}\text { Frequência } \\
\text { Porcentagem }\end{array}$ & $\begin{array}{c}25 \\
52,08\end{array}$ & $\begin{array}{c}15 \\
31,25\end{array}$ & $\begin{array}{c}1 \\
2,08\end{array}$ & $\begin{array}{c}0 \\
0,00\end{array}$ & $\begin{array}{c}7 \\
14,58\end{array}$ & $\begin{array}{c}48 \\
100\end{array}$ \\
\hline RATO & $\begin{array}{c}\text { Frequência } \\
\text { Porcentagem }\end{array}$ & $\begin{array}{c}24 \\
50,00\end{array}$ & $\begin{array}{c}14 \\
29,17\end{array}$ & $\begin{array}{c}1 \\
2,08\end{array}$ & $\begin{array}{c}0 \\
0,00\end{array}$ & $\begin{array}{c}9 \\
18,75\end{array}$ & $\begin{array}{c}48 \\
100\end{array}$ \\
\hline PUMA & $\begin{array}{l}\text { Frequência } \\
\text { Porcentagem }\end{array}$ & $\begin{array}{c}18 \\
37,50\end{array}$ & $\begin{array}{c}15 \\
31,25\end{array}$ & $\begin{array}{c}2 \\
4,17\end{array}$ & $\begin{array}{c}10 \\
20,83\end{array}$ & $\begin{array}{c}3 \\
6,25\end{array}$ & $\begin{array}{c}48 \\
100\end{array}$ \\
\hline MULA & $\begin{array}{l}\text { Frequência } \\
\text { Porcentagem }\end{array}$ & $\begin{array}{c}15 \\
31,25\end{array}$ & $\begin{array}{c}24 \\
50,00\end{array}$ & $\begin{array}{c}4 \\
8,33\end{array}$ & $\begin{array}{c}1 \\
2,08\end{array}$ & $\begin{array}{c}4 \\
8,33\end{array}$ & $\begin{array}{c}48 \\
100\end{array}$ \\
\hline NUCA & $\begin{array}{l}\text { Frequência } \\
\text { Porcentagem }\end{array}$ & $\begin{array}{c}11 \\
22,92\end{array}$ & $\begin{array}{c}21 \\
43,75\end{array}$ & $\begin{array}{c}4 \\
8,33\end{array}$ & $\begin{array}{c}6 \\
12,50\end{array}$ & $\begin{array}{c}6 \\
12,50\end{array}$ & $\begin{array}{c}48 \\
100\end{array}$ \\
\hline Total & $\begin{array}{c}\text { Frequência } \\
\text { Porcentagem }\end{array}$ & $\begin{array}{c}312 \\
54,17\end{array}$ & $\begin{array}{c}153 \\
26,56\end{array}$ & $\begin{array}{c}13 \\
2,26\end{array}$ & $\begin{array}{c}56 \\
9,72 \\
\end{array}$ & $\begin{array}{c}42 \\
7,29\end{array}$ & $\begin{array}{l}576 \\
100\end{array}$ \\
\hline
\end{tabular}

As palavras que tiveram maior quantidade de respostas convencionais (consoantes pertinentes) foram "Beco" (77,08\%) e "Vejo" (75\%), ao passo que "Nuca" (22,92\%) e "Mula" $(31,25 \%)$ tiveram as menores porcentagens de respostas convencionais. Foram exatamente essas que tiveram maior frequência pela vogal que compõe a sílaba $(43,75 \%$ e $50 \%$, respectivamente). Ou seja, quando não optaram pela consoante pertinente, que seria a resposta correta, optaram por escolher a vogal, ainda que esta já estivesse grafada no papel (ressalta-se que foi omitida da folha de teste somente a primeira letra da palavra). Esse dado aponta que as 
crianças conseguem realizar uma análise bastante apurada da primeira sílaba, já que ficam entre a consoante ou a vogal pertinente.

Entre as palavras, a que mais teve respostas distantes da convencional foi "Rato", com $18,75 \%$ de respostas não convencionais.

Para realizar uma análise mais detalhada, essas cinco categorias de respostas (letra alvo, vogal que compõe a sílaba, outra vogal, consoante próxima fonologicamente, consoante fonologicamente distante) foram reagrupadas de forma resumida em dois grupos - um que reuniu as respostas pertinentes e outro que continha as respostas não pertinentes. Lembrando que consideramos pertinente somente a escolha pela consoante convencional e não pertinente a escolha por todas as demais opções. A Tabela 51 resume o agrupamento realizado.

Tabela 51: Descrição das categorias que compõem os agrupamentos mais e menos pertinentes

\begin{tabular}{cc}
\hline Pertinentes & Não pertinentes \\
\hline Letra alvo & Vogal que compõe a sílaba \\
& Outra Vogal \\
& Consoante próxima fonologicamente \\
& Consoante Distante fonologicamente \\
\hline
\end{tabular}

Com isso, constatamos que, das 576 respostas obtidas, a maioria apresentou a letra convencional: $54,17 \%$ (312 respostas) das respostas foram pertinentes, diante de $45,83 \%$ (264 respostas) não pertinentes.

\subsubsection{Análise por grupo de palavras}

Até agora observamos o comportamento das respostas de modo mais global, a seguir, iniciamos a análise das respostas no interior de cada grupo de palavras, que foram organizadas segundo a motivação fonológica da sílaba inicial: grupo de palavras iniciadas por sílaba motivada, grupo de palavras iniciadas por sílabas de contraste, grupo de palavras iniciadas por sílabas com consoante sem motivação fonológica. Na Tabela 52, apresentamos os resultados em cada categoria de análise, de acordo com cada grupo de palavras. 
Tabela 52: Frequência e porcentagem de respostas da tarefa de completar palavras, por tipo de motivação da sílaba inicial $(\mathrm{N}=576)$

\begin{tabular}{|c|c|c|c|c|c|c|c|}
\hline $\begin{array}{l}\text { Tipo de } \\
\text { Palavra } \\
\end{array}$ & & $\begin{array}{l}\text { Letra } \\
\text { alvo }\end{array}$ & $\begin{array}{c}\text { Vogal } \\
\text { que } \\
\text { compõe } \\
\text { a sílaba }\end{array}$ & $\begin{array}{c}\text { Letra } \\
\mathbf{E}\end{array}$ & $\begin{array}{c}\text { Próxima } \\
\text { fonologicamente }\end{array}$ & Distante & $\begin{array}{c}\text { Total } \\
\text { por } \\
\text { linha } \\
\end{array}$ \\
\hline $\begin{array}{l}\text { Sílaba } \\
\text { motivada }\end{array}$ & $\begin{array}{c}\text { Frequência } \\
\text { Porcentagem }\end{array}$ & $\begin{array}{c}141 \\
73,44\end{array}$ & $\begin{array}{c}19 \\
9,90\end{array}$ & $\begin{array}{c}0 \\
0,00\end{array}$ & $\begin{array}{c}24 \\
12,50\end{array}$ & $\begin{array}{c}8 \\
4,17\end{array}$ & $\begin{array}{c}192 \\
100,00\end{array}$ \\
\hline $\begin{array}{l}\text { Sílaba de } \\
\text { contraste }\end{array}$ & $\begin{array}{l}\text { Frequência } \\
\text { Porcentagem }\end{array}$ & $\begin{array}{c}96 \\
50,00\end{array}$ & $\begin{array}{c}60 \\
31,25\end{array}$ & $\begin{array}{c}3 \\
1,56\end{array}$ & $\begin{array}{c}25 \\
13,02\end{array}$ & $\begin{array}{c}8 \\
4,17\end{array}$ & $\begin{array}{c}192 \\
100,00\end{array}$ \\
\hline $\begin{array}{c}\text { Sílaba } \\
\text { não } \\
\text { motivada }\end{array}$ & $\begin{array}{l}\text { Frequência } \\
\text { Porcentagem }\end{array}$ & $\begin{array}{c}75 \\
39,06\end{array}$ & $\begin{array}{c}74 \\
38,54\end{array}$ & $\begin{array}{c}10 \\
5,21\end{array}$ & $\begin{array}{c}7 \\
3,65\end{array}$ & $\begin{array}{c}26 \\
13,54\end{array}$ & $\begin{array}{c}192 \\
100,00\end{array}$ \\
\hline Total & $\begin{array}{c}\text { Frequência } \\
\text { Porcentagem }\end{array}$ & $\begin{array}{c}312 \\
54,17\end{array}$ & $\begin{array}{c}153 \\
26,56\end{array}$ & $\begin{array}{c}13 \\
2,26\end{array}$ & $\begin{array}{c}56 \\
9,72\end{array}$ & $\begin{array}{c}42 \\
7,29\end{array}$ & $\begin{array}{c}576 \\
100,00\end{array}$ \\
\hline
\end{tabular}

Ao analisarmos as respostas segundo a motivação fonológica das sílabas iniciais de cada palavra, observamos que a motivação fonológica teve influência na escolha das crianças (141 casos ou 73,44\% das respostas), sendo que os segmentos motivados foram os que mais facilitaram a escolha pela letra correta. Ou seja, o nome da sílaba ter a mesma representação sonora que o da letra permitiu melhor reconhecimento da letra correspondente.

Em seguida, encontramos as sílabas de contraste (96 casos ou 50\%), e, por último, as sílabas não motivadas, com 75 casos ou 39,06\% das respostas.

Se analisarmos do ponto de vista da escolha pela vogal, o resultado se inverte: as não motivadas proporcionaram mais escolhas pela vogal (38,54\%), depois as de contraste $(31,50 \%)$.

A comparação por meio da prova $T$ de Student apontou que essas diferenças são estatisticamente relevantes (entre sílabas motivadas vs contraste e não motivadas - $\mathrm{T}<0,17$, e entre contraste vs não motivadas - $\mathrm{T}<0,28$ ).

$\mathrm{Na}$ Figura 11, a seguir, organizamos as respostas em duas únicas categorias: pertinentes e não pertinentes, e podemos observar sua distribuição entre os grupos de palavras. 


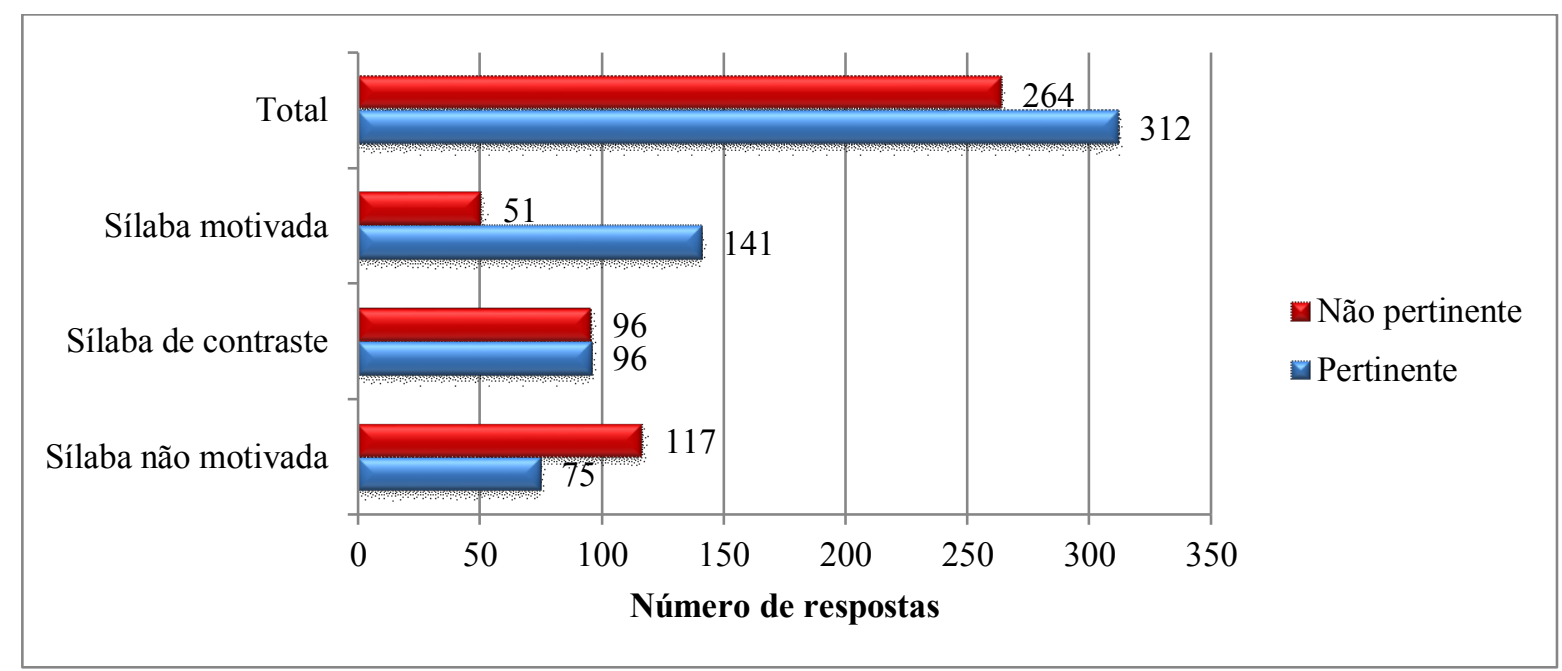

Figura 7 Frequência de respostas pertinentes e não pertinentes por grupo de palavras $(n=576)$

\subsubsection{Completar sílabas com motivação fonológica em posição inicial}

Ao organizarmos as respostas do grupo de palavras motivadas em dois subgrupos, um reunindo as respostas pertinentes (escolha pela consoante convencional) e outro as não pertinentes (vogal pertinente, outra vogal, consoante não pertinente e consoante próxima), identificamos que as pertinentes apresentam 73,44\% das respostas, enquanto que o restante (26,56\%) está associado a respostas não pertinentes. Na Tabela 53, abaixo, vemos a distribuição dos tipos de respostas pelas palavras que compõem o grupo:

Tabela 53: Porcentagem e Frequência de sílabas motivadas na tarefa de completar palavras $(\mathbf{N}=192)$

\begin{tabular}{|c|c|c|c|c|c|c|c|}
\hline 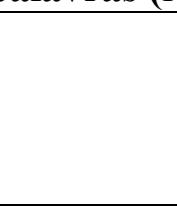 & & $\begin{array}{l}\text { Letra } \\
\text { alvo }\end{array}$ & $\begin{array}{c}\text { Vogal } \\
\text { que } \\
\text { compõe } \\
\text { a sílaba }\end{array}$ & $\begin{array}{c}\text { Letra } \\
\text { E }\end{array}$ & $\begin{array}{c}\text { Próxima } \\
\text { fonologicamente }\end{array}$ & $\begin{array}{l}\text { Consoante } \\
\text { Distante }\end{array}$ & $\begin{array}{c}\text { Total } \\
\text { por } \\
\text { linha }\end{array}$ \\
\hline \multirow{2}{*}{ T(EMA) } & Frequência & 34 & 7 & 0 & 7 & 0 & 48 \\
\hline & Porcentagem & 70,83 & 14,58 & 0,00 & 14,58 & 0,00 & 100,00 \\
\hline \multirow{2}{*}{ P(ENA) } & Frequência & 34 & 5 & 0 & 6 & 3 & 48 \\
\hline & Porcentagem & 70,83 & 10,42 & 0,00 & 12,50 & 6,25 & 100,00 \\
\hline \multirow{2}{*}{ V(EJO) } & Frequência & 36 & 5 & 0 & 5 & 2 & 48 \\
\hline & Porcentagem & 75,00 & 10,42 & 0,00 & 10,42 & 4,17 & 100,00 \\
\hline \multirow{2}{*}{$\mathrm{B}(\mathrm{ECO})$} & Frequência & 37 & 2 & 0 & 6 & 3 & 48 \\
\hline & Porcentagem & 77,08 & 4,17 & 0,00 & 12,50 & 6,25 & 100,00 \\
\hline \multirow{2}{*}{$\begin{array}{l}\text { Total de } \\
\text { respostas }\end{array}$} & Frequência & 141 & 19 & 0 & 24 & 8 & 192 \\
\hline & Porcentagem & 73,44 & 9,90 & 0,00 & 12,50 & 4,17 & 100,00 \\
\hline
\end{tabular}


De acordo com a Tabela 53 é possível observar que em todas as palavras a escolha da sílaba convencional foi superior à escolha de outras respostas. Entre as palavras completadas, a que mais foi apresentada corretamente foi "beco" (77,08\%), e as palavras com a menor quantidade de acertos foram "tema" e "pena", ambas com 70,83\%.

Nesse grupo de palavras, as crianças que não optaram pela letra convencional recorreram mais frequentemente à consoante próxima do que à vogal (como ocorreu nos demais grupos), o que evidencia que a motivação fonológica influenciou no êxito da tarefa, pois o nome da letra que buscavam já estava dado ao pronunciar a sílaba ou o início da palavra.

\subsubsection{Completar sílabas de contraste em posição inicial}

No grupo de palavras iniciadas por sílabas de contraste observamos que exatamente a metade $(50 \%)$ das respostas foi pertinente e a outra metade não pertinente. Na Tabela 54, vemos a distribuição dos tipos de respostas pelas palavras que compõem o grupo:

Tabela 54: Porcentagem e Frequência de sílabas de contraste na tarefa de completar palavras $(\mathbf{N}=192)$

\begin{tabular}{|c|c|c|c|c|c|c|c|}
\hline & & $\begin{array}{c}\text { Letra } \\
\text { alvo }\end{array}$ & $\begin{array}{c}\text { Vogal } \\
\text { que } \\
\text { compõe } \\
\text { a sílaba }\end{array}$ & $\begin{array}{c}\text { Letra } \\
\text { E }\end{array}$ & $\begin{array}{c}\text { Próxima } \\
\text { fonologicamente }\end{array}$ & $\begin{array}{c}\text { Consoante } \\
\text { Distante }\end{array}$ & $\begin{array}{c}\text { Total } \\
\text { por } \\
\text { linha }\end{array}$ \\
\hline \multirow{2}{*}{$\mathrm{T}(\mathrm{OMA})$} & Frequência & 25 & 16 & 1 & 4 & 2 & 48 \\
\hline & Porcentagem & 52,08 & 33,33 & 2,08 & 8,33 & 4,17 & 100,00 \\
\hline \multirow{2}{*}{ P(UMA) } & Frequência & 18 & 15 & 2 & 10 & 3 & 48 \\
\hline & Porcentagem & 37,50 & 31,25 & 4,17 & 20,83 & 6,25 & 100,00 \\
\hline \multirow{2}{*}{ V(ILA) } & Frequência & 28 & 11 & 0 & 8 & 1 & 48 \\
\hline & Porcentagem & 58,33 & 22,92 & 0,00 & 16,67 & 2,08 & 100,00 \\
\hline \multirow{2}{*}{$\mathrm{B}(\mathrm{OCA})$} & Frequência & 25 & 18 & 0 & 3 & 2 & 48 \\
\hline & Porcentagem & 52,08 & 37,50 & 0,00 & 6,25 & 4,17 & 100,00 \\
\hline \multirow{2}{*}{$\begin{array}{l}\text { Total de } \\
\text { respostas }\end{array}$} & Frequência & 96 & 60 & 3 & 25 & 8 & 192 \\
\hline & Porcentagem & 50,00 & 31,25 & 1,56 & 13,02 & 4,17 & 100,00 \\
\hline
\end{tabular}

Entre as palavras apresentadas, a que mais foi completada corretamente foi "Vila" (58,33\%), e a de menor índice de acerto foi "Puma", com 37,50\%.

Vale ressaltar que nesse grupo de palavras, diferentemente do que ocorreu com as palavras iniciadas por sílabas motivadas, outra categoria de resposta bastante representativa foi a da "vogal que compõe a sílaba", com 31,25\% das respostas. Isso mostra que, apesar de muitas 
crianças conhecerem as consoantes "T", "P", "V" e "B", pois as utilizaram em contexto motivado, não puderam fazer o mesmo uso dessas mesmas letras em outra situação.

\subsubsection{Completar sílabas não motivadas em posição inicial}

No grupo de palavras iniciadas por sílabas não motivadas observamos que as respostas se comportaram de forma diferente do que ocorreu nos demais grupos: a resposta pertinente (letra alvo) representou a menor porcentagem (39,06\%), enquanto as menos pertinentes representaram a maior porcentagem $(60,94 \%)$.

Tabela 55: Porcentagem e Frequência de sílabas não motivadas na tarefa de completar palavras $(\mathrm{N}=192)$

\begin{tabular}{|c|c|c|c|c|c|c|c|}
\hline & & $\begin{array}{c}\text { Letra } \\
\text { alvo }\end{array}$ & $\begin{array}{c}\text { Vogal } \\
\text { que } \\
\text { compõe } \\
\text { a sílaba } \\
\end{array}$ & $\begin{array}{c}\text { Letra } \\
\mathbf{E}\end{array}$ & $\begin{array}{c}\text { Próxima } \\
\text { fonologicamente }\end{array}$ & $\begin{array}{c}\text { Consoante } \\
\text { Distante }\end{array}$ & $\begin{array}{c}\text { Total } \\
\text { por } \\
\text { linha } \\
\end{array}$ \\
\hline N(UCA) & $\begin{array}{l}\text { Frequência } \\
\text { Porcentagem }\end{array}$ & $\begin{array}{c}11 \\
22,92\end{array}$ & $\begin{array}{c}21 \\
43,75\end{array}$ & $\begin{array}{c}4 \\
8,33\end{array}$ & $\begin{array}{c}6 \\
12,50\end{array}$ & $\begin{array}{c}6 \\
12,50\end{array}$ & $\begin{array}{c}48 \\
100,00\end{array}$ \\
\hline L(IMA) & $\begin{array}{c}\text { Frequência } \\
\text { Porcentagem }\end{array}$ & $\begin{array}{c}25 \\
52,08\end{array}$ & $\begin{array}{c}15 \\
31,25\end{array}$ & $\begin{array}{c}1 \\
2,08\end{array}$ & $\begin{array}{c}0 \\
0,00\end{array}$ & $\begin{array}{c}7 \\
14,58\end{array}$ & $\begin{array}{c}48 \\
100,00\end{array}$ \\
\hline R(ATO) & $\begin{array}{c}\text { Frequência } \\
\text { Porcentagem }\end{array}$ & $\begin{array}{c}24 \\
50,00\end{array}$ & $\begin{array}{c}14 \\
29,17\end{array}$ & $\begin{array}{c}1 \\
2,08\end{array}$ & $\begin{array}{c}0 \\
0,00\end{array}$ & $\begin{array}{c}9 \\
18,75\end{array}$ & $\begin{array}{c}48 \\
100,00\end{array}$ \\
\hline M(ULA) & $\begin{array}{c}\text { Frequência } \\
\text { Porcentagem }\end{array}$ & $\begin{array}{c}15 \\
31,25 \\
\end{array}$ & $\begin{array}{c}24 \\
50,00 \\
\end{array}$ & $\begin{array}{c}4 \\
8,33 \\
\end{array}$ & $\begin{array}{c}1 \\
2,08 \\
\end{array}$ & $\begin{array}{c}4 \\
8,33 \\
\end{array}$ & $\begin{array}{c}48 \\
100,00 \\
\end{array}$ \\
\hline $\begin{array}{l}\text { Total de } \\
\text { respostas }\end{array}$ & $\begin{array}{c}\text { Frequência } \\
\text { Porcentagem }\end{array}$ & $\begin{array}{c}75 \\
39,06\end{array}$ & $\begin{array}{c}74 \\
38,54\end{array}$ & $\begin{array}{c}10 \\
5,21\end{array}$ & $\begin{array}{c}7 \\
3,65\end{array}$ & $\begin{array}{c}26 \\
13,54\end{array}$ & $\begin{array}{c}192 \\
100,00\end{array}$ \\
\hline
\end{tabular}

Contudo, ao observarmos o comportamento de cada palavra do grupo, observamos certo equilíbrio entre as respostas pertinentes e não pertinentes das palavras "RATO" e "LIMA" (52,08\% e 50\% de acerto, respectivamente). Já nas palavras "NUCA" e "MULA" (77\% e $68,75 \%$ de erros, respectivamente), o número de erros foi bem superior ao de acertos.

Nesse grupo de palavras, a opção pela vogal foi mais frequente que nos demais grupos (38,54\%, contra $31,5 \%$ nas de contraste e $26,56 \%$ nas motivadas), equiparando-se, inclusive, à quantidade de respostas convencionais $(38,54 \%$ e $39,06 \%$, respectivamente). Ou seja, o fato de as sílabas não serem motivadas parece ter influenciado para que as crianças escolhessem com maior frequência as vogais. 


\subsubsection{Análise por Nível de Escrita}

Ao analisarmos o efeito que o nível de escrita tem sobre as respostas das crianças na tarefa de completar palavras observamos que, quanto mais avançado o nível, maior a quantidade de respostas pertinentes. Como vê-se na Tabela 56, o grupo de crianças SSVC teve a menor quantidade de acertos (63 casos, que representam 32,81\% das 192 respostas possíveis). Em segundo lugar, veio o grupo SCVC, com 82 casos, que representam 42,17\% das 192 respostas possíveis, e, por último, o grupo SA, com a maior quantidade de acertos: 167 casos, que representam $86,98 \%$.

A comparação (por meio do Teste T) entre o comportamento das respostas das crianças, por nível de escrita, apontou que os resultados são estatisticamente discrepantes (em todos os testes os resultados foram de $\mathrm{T}<0,06)$.

Tabela 56: Frequência e porcentagens de respostas pertinentes por nível de escrita e tipo de palavra $(\mathrm{N}=312)$

\begin{tabular}{|c|c|c|c|c|c|}
\hline Nível de escrita & & Motivada & Contraste & $\begin{array}{c}\text { Não } \\
\text { Motivada }\end{array}$ & $\begin{array}{l}\text { Total por } \\
\text { linha }\end{array}$ \\
\hline \multirow{3}{*}{ SSV } & \multirow{3}{*}{$\begin{array}{l}\text { Frequência } \\
\text { \% no próprio } \\
\text { grupo } \\
\text { \% total }\end{array}$} & 35 & 17 & 11 & 63 \\
\hline & & 55,56 & 26,98 & 17,46 & 100,00 \\
\hline & & 33,65 & 16,35 & 10,58 & 20,19 \\
\hline \multirow{3}{*}{$\mathrm{SCV}$} & \multirow{3}{*}{$\begin{array}{l}\text { Frequência } \\
\text { \% no próprio } \\
\text { grupo } \\
\% \text { total }\end{array}$} & 46 & 22 & 14 & 82 \\
\hline & & 56,10 & 26,83 & 17,07 & 100,00 \\
\hline & & 44,23 & 21,15 & 13,46 & 26,28 \\
\hline \multirow{3}{*}{ SA } & \multirow{3}{*}{$\begin{array}{l}\text { Frequência } \\
\text { \% no próprio } \\
\text { grupo } \\
\% \text { total }\end{array}$} & 60 & 57 & 50 & 167 \\
\hline & & 35,93 & 34,13 & 29,94 & 100,00 \\
\hline & & 57,69 & 54,81 & 48,08 & 53,53 \\
\hline \multirow{2}{*}{ Total de respostas } & Frequência & 141 & 96 & 75 & 312 \\
\hline & $\%$ total & 45,19 & 30,77 & 24,04 & 100,00 \\
\hline
\end{tabular}

Ao relacionarmos o nível conceitual e o tipo de palavras (motivada, contraste e não motivadas), percebemos que o mesmo padrão se mantém independentemente do tipo de sílaba: conforme aumenta o nível de escrita, maior é o índice de acertos.

As crianças com escritas SSVC foram as que apresentaram menos respostas pertinentes no total e em cada tipo de palavra. Em segundo lugar, estiveram as crianças SCVC, e, por fim, 
as de escritas SA, que apresentaram as respostas mais pertinentes no total e em todos os grupos de palavras.

De modo geral, as crianças apresentaram melhor desempenho entre as palavras do grupo motivado. Essa diferença pareceu especialmente relevante entre as crianças com conceitualizações de escrita menos avançadas. O índice de acertos das motivadas para os SSVC e os SCVC foi praticamente o dobro quando comparado aos demais grupos de palavras. Já em relação ao grupo SA, a diferença maior ocorreu entre as motivadas e não motivadas, mas essa diferença não atingiu 10\%. Para avaliar quantitativamente a relação entre o nível de escrita e a quantidade de acertos, e averiguar sua validade estatística, calculamos uma prova de Quiquadrado:

Tabela 57: Teste de Qui-quadrado entre nível de escrita e o total dos resultados de completar palavras motivadas

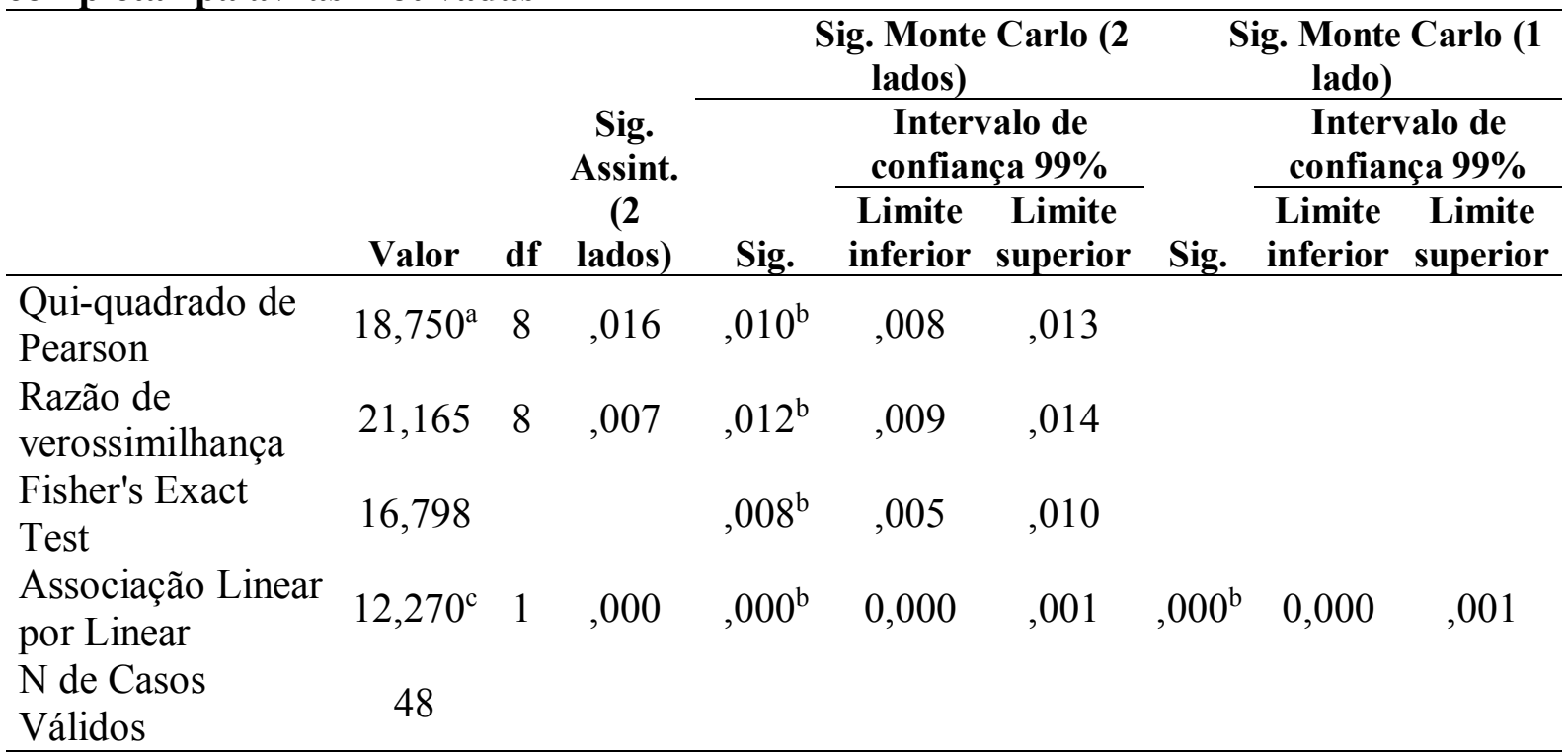

a. 12 células $(80,0 \%)$ esperam contagem menor do que 5 . A contagem mínima esperada é 1,00.

b. Baseado em 10000 tabelas amostradas com valor inicial 2000000.

c. A estatística padronizada é 3,503. 
Tabela 58: Teste de Qui-quadrado entre nível de escrita e total dos resultados de completar palavras de contraste

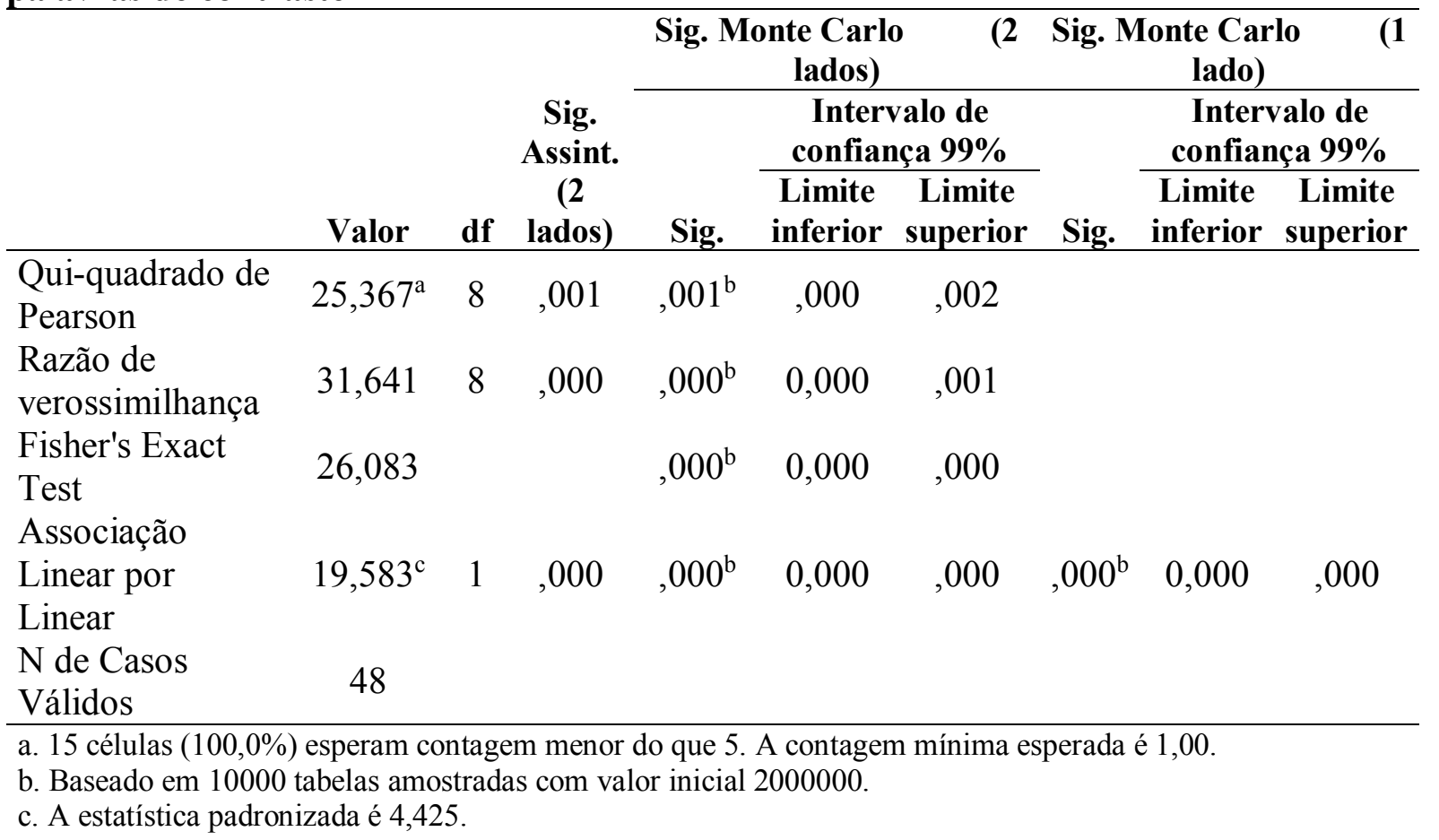

Tabela 59: Teste de Qui-quadrado entre nível de escrita e total dos resultados de completar palavras não motivadas

\begin{tabular}{|c|c|c|c|c|c|c|c|c|c|}
\hline & \multirow[b]{3}{*}{ Valor } & \multirow[b]{3}{*}{ df } & \multirow{3}{*}{$\begin{array}{l}\text { Sig. } \\
\text { Assint. } \\
\quad(2 \\
\text { lados })\end{array}$} & \multicolumn{3}{|c|}{ Sig. Monte Carlo (2 lados) } & \multicolumn{3}{|c|}{$\begin{array}{c}\text { Sig. Monte Carlo (1 } \\
\text { lado) }\end{array}$} \\
\hline & & & & & $\begin{array}{r}\text { Inter } \\
\text { confian }\end{array}$ & $\begin{array}{l}\text { valo de } \\
\text { ç̧a } 99 \%\end{array}$ & \multirow[b]{2}{*}{ Sig. } & \multicolumn{2}{|c|}{$\begin{array}{c}\text { Intervalo de } \\
\text { confiança } 99 \%\end{array}$} \\
\hline & & & & Sig. & $\begin{array}{c}\text { Limite } \\
\text { inferior }\end{array}$ & $\begin{array}{c}\text { Limite } \\
\text { superior }\end{array}$ & & $\begin{array}{l}\text { Limite } \\
\text { inferior }\end{array}$ & $\begin{array}{c}\text { Limite } \\
\text { superior }\end{array}$ \\
\hline $\begin{array}{l}\text { Qui-quadrado de } \\
\text { Pearson }\end{array}$ & $25,367^{\mathrm{a}}$ & 8 & ,001 &, $001^{\mathrm{b}}$ & ,000 & ,002 & & & \\
\hline $\begin{array}{l}\text { Razão de } \\
\text { verossimilhança }\end{array}$ & 31,641 & 8 & ,000 &, $000^{\mathrm{b}}$ & 0,000 & ,001 & & & \\
\hline $\begin{array}{l}\text { Fisher's Exact } \\
\text { Test }\end{array}$ & 26,083 & & &, $000^{\mathrm{b}}$ & 0,000 & ,000 & & & \\
\hline $\begin{array}{l}\text { Associação } \\
\text { Linear por Linear }\end{array}$ & $19,583^{c}$ & 1 & ,000 &, $000^{\mathrm{b}}$ & 0,000 & ,000 &, $000^{\mathrm{b}}$ & 0,000 & ,000 \\
\hline $\begin{array}{l}\mathrm{N} \text { de Casos } \\
\text { Válidos }\end{array}$ & 48 & & & & & & & & \\
\hline $\begin{array}{l}\text { a. } 15 \text { células }(100 \text {, } \\
1,00 \text {. } \\
\text { b. Baseado em } 10 \\
\text { c. A estatística pac }\end{array}$ & o) espe & & tag & hen & que & $\begin{array}{l}\text { A cont } \\
20000\end{array}$ & $\mathrm{~m} \mathrm{n}$ & ma espe & erada é \\
\hline
\end{tabular}


Para as crianças de todos os níveis conceituais as sílabas motivadas parecem ter favorecido a escolha pela letra pertinente, já que a porcentagem de acerto foi maior para esse tipo de palavra, seguido pelas de contraste e, por último, pelas não motivadas. Nesse tipo de tarefa, a motivação fonológica da letra parece ter exercido influência significativa.

Observemos agora o comportamento das respostas dentro de cada nível conceitual.

\section{Silábico sem valor sonoro convencional (SSVC)}

A coincidência entre o contexto silábico e o nome da letra (sílabas motivadas) possibilitou que 54,69\% (35 acertos entre 64 crianças) das crianças SSVC reconhecessem o segmento inicial e o relacionassem com a respectiva letra. A Tabela 60 expõe a distribuição das respostas desse grupo:

Tabela 60: Frequência e porcentagens de respostas do grupo SSV por tipo de palavra e categorias de análise $(n=192)$

\begin{tabular}{ccccccc}
\hline $\begin{array}{c}\text { Tipo de } \\
\text { sílaba }\end{array}$ & $\begin{array}{c}\text { Vogal } \\
\text { Pertinente }\end{array}$ & $\begin{array}{c}\text { Outra } \\
\text { vogal }\end{array}$ & $\begin{array}{c}\text { Consoante } \\
\text { Pertinente }\end{array}$ & $\begin{array}{c}\text { Consoante } \\
\text { não } \\
\text { pertinente }\end{array}$ & $\begin{array}{c}\text { Consoante } \\
\text { próxima }\end{array}$ & Total \\
\hline \multirow{2}{*}{ Motivada } & 8 & 0 & 35 & 8 & 13 & 64 \\
& 12,50 & 0,00 & 54,69 & 12,50 & 20,31 & 100,00 \\
& & & & & & \\
Contraste & 23 & 2 & 17 & 7 & 15 & 64 \\
& 35,94 & 3,13 & 26,56 & 10,94 & 23,44 & 100,00 \\
\multirow{2}{*}{ Não Motivada } & 21 & 9 & 11 & 19 & 4 & 64 \\
& 32,81 & 14,06 & 17,19 & 29,69 & 6,25 & 100,00 \\
\hline \multirow{2}{*}{ Total } & 52 & 11 & 63 & 34 & 32 & 192 \\
& 27,08 & 5,73 & 32,81 & 17,71 & 16,67 & 100,00 \\
\hline
\end{tabular}

Nas sílabas de contraste, apesar de serem compostas pelas mesmas letras motivadas, o que mais sobressaiu para as crianças foi a vogal $(35,94 \% \mathrm{f}=23)$. Contudo, atribuímos esse comportamento ao fato de que em 75\% (3/4) das palavras ditadas as sílabas iniciais eram formadas por consoantes do tipo plosiva ${ }^{29}$ (Toma, Boca, Puma), ou seja, não prolongáveis, o que dificultaria seu reconhecimento enquanto facilitaria o reconhecimento da vogal que as compõe, já que as vogais representam os fonemas com maior condição de prolongamento

\footnotetext{
${ }^{29}$ Plosiva, explosiva ou oclusiva é a categorização das consoantes que são produzidas após a interrupção momentânea da corrente de ar, advinda da expiração. São exemplos de consoantes plosivas no portuguêsbrasileiro os fonemas /b/,/d/, /k/, /g/, /d/ e /t/.
} 
(Fernández, 2015). Essa hipótese é reforçada ao observarmos o comportamento das respostas da palavra VILA, como mostra a Tabela 61:

Tabela 61: Distribuição das frequências e porcentagens de respostas por palavra de contraste, no grupo de crianças SSV

\begin{tabular}{|c|c|c|c|c|c|c|c|}
\hline & & $\begin{array}{l}\text { Letra } \\
\text { alvo }\end{array}$ & $\begin{array}{c}\text { Vogal } \\
\text { que } \\
\text { compõe } \\
\text { a sílaba }\end{array}$ & $\begin{array}{l}\text { Outra } \\
\text { vogal }\end{array}$ & $\begin{array}{c}\text { Próxima } \\
\text { fonologicamente }\end{array}$ & $\begin{array}{c}\text { Consoante } \\
\text { Distante }\end{array}$ & $\begin{array}{c}\text { Total } \\
\text { por } \\
\text { linha }\end{array}$ \\
\hline \multirow{2}{*}{$\mathrm{T}(\mathrm{OMA})$} & Frequência & 4 & 7 & 1 & 2 & 2 & 16 \\
\hline & Porcentagem & 25 & 43,75 & 6,25 & 12,5 & 12,5 & 100 \\
\hline \multirow{2}{*}{ P(UMA) } & Frequência & 3 & 6 & 1 & 3 & 3 & 16 \\
\hline & Porcentagem & 18,75 & 37,5 & 6,25 & 18,75 & 18,75 & 100 \\
\hline \multirow{2}{*}{ V(ILA) } & Frequência & 6 & 3 & 0 & 7 & 0 & 16 \\
\hline & Porcentagem & 37,5 & 18,75 & 0 & 43,75 & 0 & 100 \\
\hline \multirow{2}{*}{$\mathrm{B}(\mathrm{OCA})$} & Frequência & 4 & 7 & 0 & 3 & 2 & 16 \\
\hline & Porcentagem & 25 & 43,75 & 0 & 18,75 & 12,5 & 100 \\
\hline \multirow{2}{*}{$\begin{array}{l}\text { Total de } \\
\text { respostas }\end{array}$} & Frequência & 17 & 23 & 2 & 15 & 7 & 64 \\
\hline & Porcentagem & 26,56 & 35,94 & 3,13 & 23,44 & 10,94 & 100 \\
\hline
\end{tabular}

$\mathrm{O}$ fonema $/ \mathrm{v} /$, que era a parte que faltava na palavra, é um fonema fricativo, ou seja, tem a possibilidade de ser prolongado e isolado no momento da enunciação, tornando-o mais evidente. Por essa razão, nas demais palavras as respostas concentraram-se nas vogais pertinentes, e, no caso de VILA, concentraram-se na consoante próxima, que foi a letra "F" (par fonêmico de /v/), e na resposta correta, que era a escolha do próprio "V".

A Figura 8 apresenta o tipo de resposta das crianças deste nível conceitual em cada grupo de palavras, deixando bastante evidente a concentração da utilização da letra alvo nas sílabas do tipo motivado e a utilização das vogais, de forma mais frequente, nas sílabas de contraste e não motivado. 


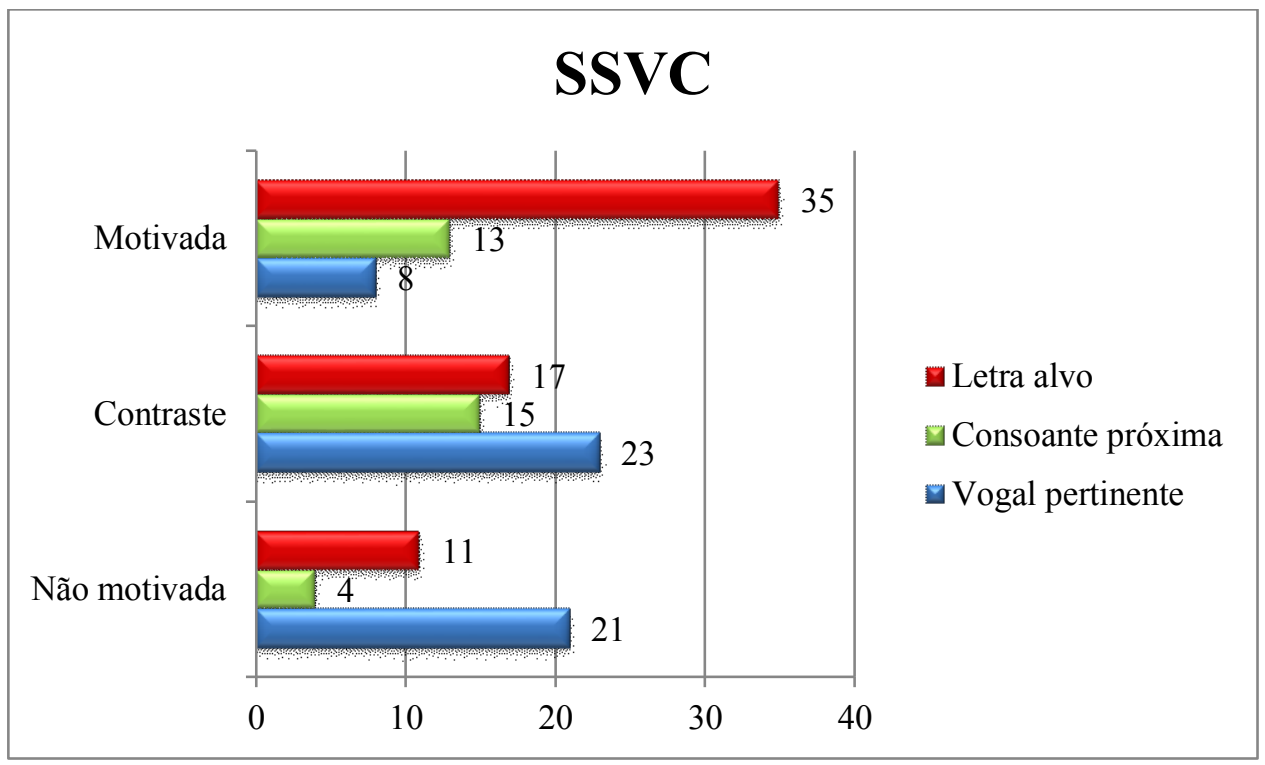

Figura 8 Desempenho das crianças SSV em cada grupo de palavras.

\section{Silábico com valor sonoro convencional (SCVC)}

As crianças SCVC acertaram mais frequentemente as palavras do tipo motivado (46 casos, ou 71,87\%), porém, entre aquelas que não acertaram, a escolha mais frequente foi pela vogal pertinente (11 casos, ou 17,18\%). Já nas palavras de contraste e não motivadas, escolheram utilizar mais vezes a vogal (54,68\%, ou 35 casos), que é a letra alvo $(34,37 \%$, ou 22 casos). Nas palavras não motivadas essa diferença foi ainda mais expressiva: $65,62 \%$ (42 casos) optaram por utilizar as vogais contra $21,87 \%$ (14 casos) que utilizaram a letra alvo. $(\mathrm{N}=64)$. A Tabela 62 expõe a distribuição das respostas desse grupo:

Tabela 62: Frequência e porcentagens de respostas do grupo SCV por tipo de palavra e categorias de análise $(n=192)$

\begin{tabular}{ccccccc}
\hline $\begin{array}{c}\text { Tipo de } \\
\text { sílaba }\end{array}$ & $\begin{array}{c}\text { Vogal } \\
\text { Pertinente }\end{array}$ & $\begin{array}{c}\text { Outra } \\
\text { vogal }\end{array}$ & $\begin{array}{c}\text { Consoante } \\
\text { Pertinente }\end{array}$ & $\begin{array}{c}\text { Consoante } \\
\text { não } \\
\text { pertinente }\end{array}$ & $\begin{array}{c}\text { Consoante } \\
\text { próxima }\end{array}$ & Total \\
\hline \multirow{2}{*}{ Motivada } & 11 & 0 & 46 & 0 & 7 & 64 \\
& 17,19 & 0,00 & 71,88 & 0,00 & 10,94 & 100,00 \\
& & & & & & \\
Contraste & 35 & 1 & 22 & 1 & 5 & 64 \\
& 54,69 & 1,56 & 34,38 & 1,56 & 7,81 & 100,00 \\
Não & 42 & 0 & 14 & 7 & 1 & 64 \\
Motivada & 65,63 & 0,00 & 21,88 & 10,94 & 1,56 & 100,00 \\
\hline \multirow{2}{*}{ Total } & 88 & 1 & 82 & 8 & 13 & 192 \\
& 45,83 & 0,52 & 42,71 & 4,17 & 6,77 & 100,00 \\
\hline
\end{tabular}


Essa consistência na escolha das vogais em contextos de contraste e não motivadas mostra o quão forte é a convicção da criança em sua hipótese de escrita, já que mesmo vendo a vogal grafada (pois a palavra fora apresentada tendo subtraída apenas a consoante), 45,83\% (88 casos de 192 possíveis - quantidade total de respostas das crianças SCVC para os três grupos de palavras) das crianças tiveram certeza de que o segmento que escutaram ao ouvir a palavra era representado por aquilo que conseguiam identificar - no caso, as vogais. Mantinham esta escolha, mesmo que ao grafá-las observassem e se incomodassem com a repetição das letras uma vez que a vogal que compunha a sílaba estivesse escrita previamente, assim como as demais letras das palavras.

Nesse nível conceitual, diferente do que ocorreu com as crianças SSVC em relação à palavra VILA, apesar da possibilidade de prolongamento do fonema /v/, as crianças optaram com maior frequência pela vogal (50\%). Isso mostra que a conceitualização que fazem sobre o sistema de escrita prevalece mesmo sobre as possibilidades de prolongamento dos fonemas.

Ao observarmos a Tabela 62, notamos que, apesar de as crianças SCVC utilizarem pertinentemente e com maior frequência as consoantes no contexto motivado - o que mostra que conhecem o valor sonoro da sílaba e da letra -, não foram capazes de utilizá-las com a mesma frequência em contexto de contraste.

A Figura 9 Desempenho das crianças SCV em cada grupo de palavras. Figura 9 apresenta claramente a distribuição das respostas das crianças deste nível conceitual, por grupo de palavras. A preferência pela consoante pertinente (letra alvo) nas palavras iniciadas por sílabas motivadas foi bastante expressiva, assim como pelas vogais nas sílabas de contraste e não motivadas, mantendo, neste sentido, o padrão do grupo SSVSC, embora muito mais marcado.

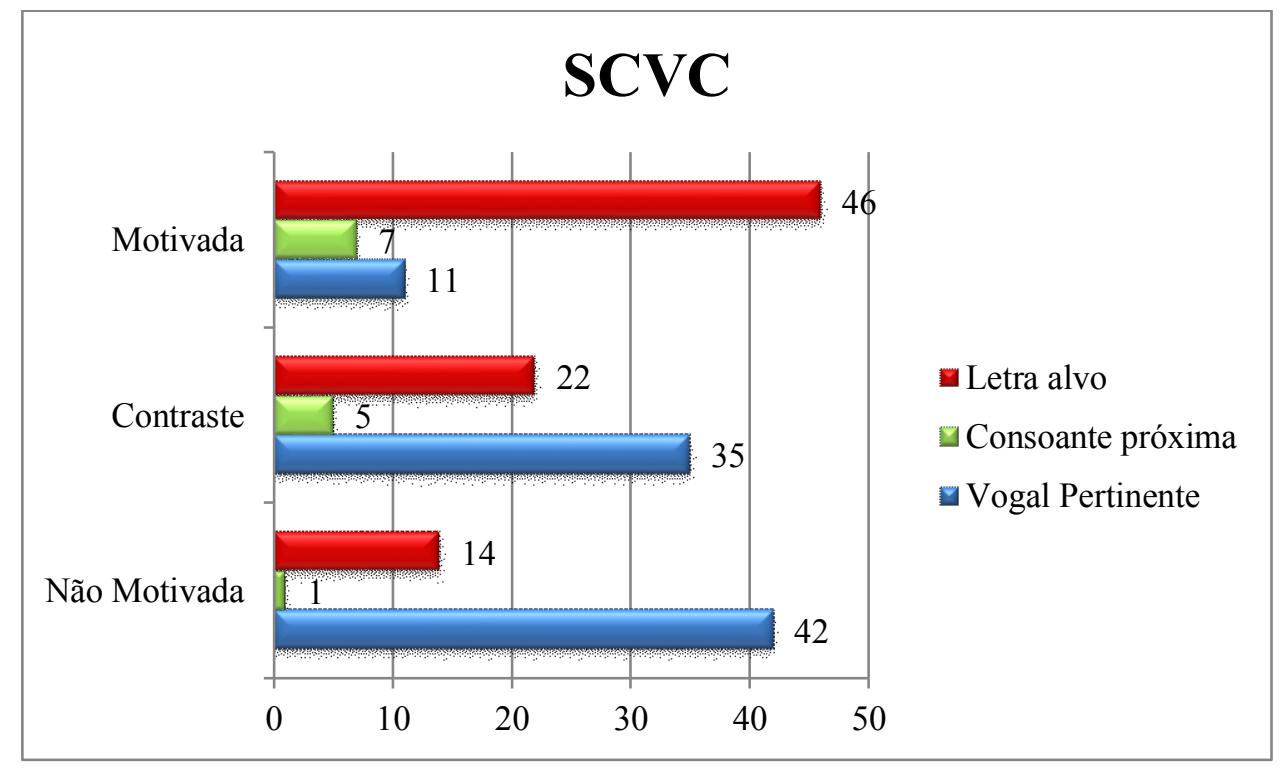


Figura 9 Desempenho das crianças SCV em cada grupo de palavras.

\section{Silábico-alfabético (SA)}

Com as crianças SA, diferentemente das demais, a maioria das respostas foi pertinente (86,98\%, diante de 13,02\% não pertinente $-\mathrm{n}=192)$, como podemos observar na Figura 10:

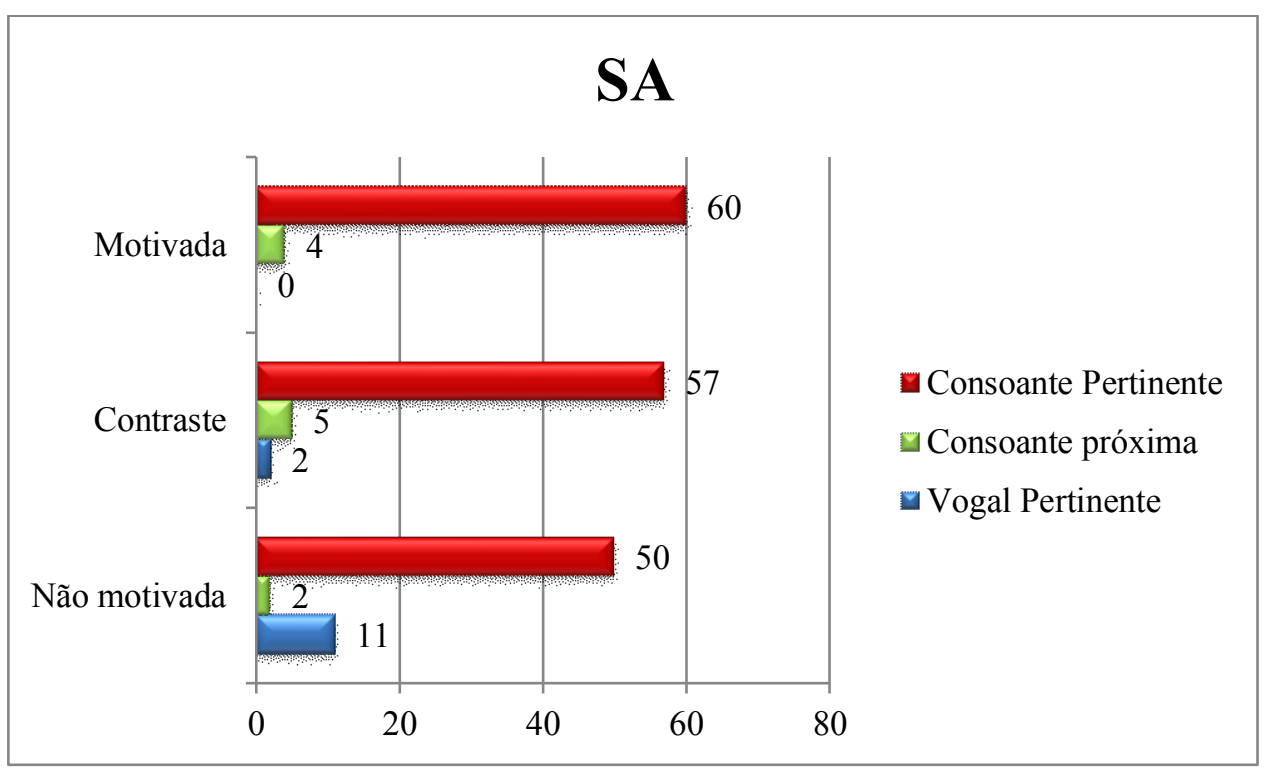

Figura 10 Desempenho das crianças SA em cada grupo de palavras.

Contudo, entre os grupos de palavras, as respostas se comportaram de modo parecido com as das crianças dos demais níveis conceituais: maior porcentagem de acertos relacionados às sílabas motivadas $(93,75 \%)$, seguidas pelas de contrastes $(89,06 \%)$ e pelas não motivadas $(78,13 \%)$. 
Tabela 63: Frequência e porcentagens de respostas do grupo SA por tipo de palavra e categorias de análise $(n=192)$

\begin{tabular}{ccccccc}
\hline $\begin{array}{c}\text { Tipo de } \\
\text { sílaba }\end{array}$ & $\begin{array}{c}\text { Vogal } \\
\text { Pertinente }\end{array}$ & $\begin{array}{c}\text { Outra } \\
\text { vogal }\end{array}$ & $\begin{array}{c}\text { Consoante } \\
\text { Pertinente }\end{array}$ & $\begin{array}{c}\text { Consoante } \\
\text { não } \\
\text { pertinente }\end{array}$ & $\begin{array}{c}\text { Consoante } \\
\text { próxima }\end{array}$ & Total \\
\hline \multirow{2}{*}{ Motivada } & 0 & 0 & 60 & 0 & 4 & 64 \\
& 0,00 & 0,00 & 93,75 & 0,00 & 6,25 & 100,00 \\
& & & & & & \\
Contraste & 3,13 & 0,00 & 89,06 & 0,00 & 7,81 & 100,00 \\
& & & & & & \\
Não Motivada & 11 & 1 & 50 & 0 & 2 & 64 \\
& 17,19 & 1,56 & 78,13 & 0,00 & 3,13 & 100,00 \\
\hline \multirow{2}{*}{ Total } & 13 & 1 & 167 & 0 & 11 & 192 \\
& 6,77 & 0,52 & 86,98 & 0,00 & 5,73 & 100,00 \\
\hline
\end{tabular}

Esse resultado indica que as sílabas do tipo motivadas, para esse nível de conceitualização da escrita, também favoreceram o reconhecimento da parte faltante, pois a coincidência entre o contexto silábico e o nome da letra possibilitou que $93,75 \%$ das crianças SA reconhecessem o segmento inicial e o relacionassem com a respectiva letra. Já as não motivadas mostraram-se mais difíceis de serem reconhecidas.

Apesar de as crianças SA acertarem mais as palavras do tipo motivadas, entre aquelas que não acertaram a escolha, a dificuldade esteve distribuída entre vogais pertinentes e consoantes próximas.

Em relação ao grupo das motivadas, como mostra a Tabela 63, as crianças SA que não escolheram a consoante correspondente optaram pela consoante próxima, o que pode denotar um erro de discriminação fonológica, já que todas as consoantes próximas eram pares fonêmicos (surdo/sonoro) com a letra alvo. Já no caso das sílabas de contraste e das não motivadas, observamos a presença de respostas não somente entre as consoantes próximas, mas também entre as vogais. A escolha pelas vogais é ainda maior nas não motivadas $(17,18 \%)$, mostrando que para tal nível conceitual esse tipo de sílaba representou maior desafio.

Ainda entre os SA, algumas palavras do grupo das sílabas de contraste foram completas de forma mais pertinente que as motivadas, como foi o caso das palavras VILA ( $100 \%$, diante de VEJA - 98,75\%) e BOCA (100\%, diante de BECO - 93,75\%). 
Ao observarmos o conjunto dos dados anteriormente analisados, encontramos uma forte correlação estatística entre os níveis de escrita das crianças e suas possibilidades de completar as palavras. A Tabela 64 resume essa informação por meio da prova de correlação bilateral de Rô Spearman.

Tabela 64: Correlação de Rô Spearman entre nível de escrita e o total de palavras completadas, por grupo segundo a motivação.

\begin{tabular}{|c|c|c|c|c|c|}
\hline & & $\begin{array}{l}\text { Nível de } \\
\text { Escrita }\end{array}$ & $\begin{array}{c}\text { Total } \\
\text { Completa } \\
\text { Contraste }\end{array}$ & $\begin{array}{c}\text { Total } \\
\text { Completa } \\
\text { Motivada }\end{array}$ & $\begin{array}{c}\text { Total } \\
\text { Completa } \\
\text { Não } \\
\text { Motivada } \\
\end{array}$ \\
\hline $\begin{array}{l}\text { Nível de } \\
\text { Escrita }\end{array}$ & $\begin{array}{l}\text { Coeficiente de } \\
\text { Correlação } \\
\text { Sig. (2 } \\
\text { extremidades) }\end{array}$ & $\begin{array}{l}1 \\
.\end{array}$ & $\begin{array}{c}, 635^{* *} \\
0\end{array}$ & $\begin{array}{c}543^{* *} \\
0\end{array}$ & $\begin{array}{c}624^{* *} \\
0\end{array}$ \\
\hline $\begin{array}{c}\text { Total } \\
\text { Completa } \\
\text { Contraste }\end{array}$ & $\begin{array}{l}\text { Coeficiente de } \\
\text { Correlação } \\
\text { Sig. (2 } \\
\text { extremidades) }\end{array}$ & $\begin{array}{c}, 635^{* *} \\
0\end{array}$ & $\begin{array}{l}1 \\
.\end{array}$ & $\begin{array}{c}592^{* *} \\
0\end{array}$ & $\begin{array}{c}584^{* *} \\
0\end{array}$ \\
\hline $\begin{array}{c}\text { Total } \\
\text { Completa } \\
\text { Motivada }\end{array}$ & $\begin{array}{l}\text { Coeficiente de } \\
\text { Correlação } \\
\text { Sig. (2 } \\
\text { extremidades) }\end{array}$ & $\begin{array}{c}543^{* *} \\
0\end{array}$ & $\begin{array}{c}592^{* *} \\
0\end{array}$ & $\begin{array}{l}1 \\
.\end{array}$ & $\begin{array}{c}316^{*} \\
0\end{array}$ \\
\hline $\begin{array}{c}\text { Total } \\
\text { Completa } \\
\text { Não } \\
\text { Motivada }\end{array}$ & $\begin{array}{l}\text { Coeficiente de } \\
\text { Correlação } \\
\text { Sig. (2 } \\
\text { extremidades) }\end{array}$ & $\begin{array}{c}, 624^{* *} \\
0\end{array}$ & $\begin{array}{c}584^{* *} \\
0\end{array}$ & $\begin{array}{c}316^{*} \\
0\end{array}$ & $\begin{array}{l}1 \\
.\end{array}$ \\
\hline
\end{tabular}

\subsubsection{Considerações Sobre as Respostas Menos Pertinentes}

Embora em menor quantidade, as respostas menos pertinentes nos permitem concluir que as crianças, apesar de saberem pouco sobre as letras nesse contexto (SSV), não escolhem de maneira aleatória suas respostas. Vejamos esses dados na Tabela 65: 
Tabela 65: Frequência e porcentagem de respostas por categoria, grupo de palavras e nível de escrita

\begin{tabular}{|c|c|c|c|c|c|c|c|c|}
\hline $\begin{array}{l}\text { Tipo de } \\
\text { sílaba }\end{array}$ & & & $\begin{array}{c}\text { Vogal } \\
\text { Pertine } \\
\text { nte }\end{array}$ & $\begin{array}{l}\text { Outra } \\
\text { vogal }\end{array}$ & $\begin{array}{l}\text { Consoante } \\
\text { Pertinente }\end{array}$ & $\begin{array}{l}\text { Consoante } \\
\text { não } \\
\text { pertinente }\end{array}$ & $\begin{array}{l}\text { Consoante } \\
\text { próxima }\end{array}$ & Total \\
\hline \multirow{6}{*}{ Motivada } & \multirow{2}{*}{ SSV } & Frequência & 8 & 0 & 35 & 8 & 13 & 64 \\
\hline & & Porcentagem & 12,50 & 0,00 & 54,69 & 12,50 & 20,31 & 100,00 \\
\hline & \multirow{2}{*}{$\mathrm{SCV}$} & Frequência & 11 & 0 & 46 & 0 & 7 & 64 \\
\hline & & Porcentagem & 17,19 & 0,00 & 71,88 & 0,00 & 10,94 & 100,00 \\
\hline & \multirow{2}{*}{ SA } & Frequência & 0 & 0 & 60 & 0 & 4 & 64 \\
\hline & & Porcentagem & 0,00 & 0,00 & 93,75 & 0,00 & 6,25 & 100,00 \\
\hline \multirow{6}{*}{ Contraste } & \multirow{2}{*}{ SSV } & Frequência & 23 & 2 & 17 & 7 & 15 & 64 \\
\hline & & Porcentagem & 35,94 & 3,13 & 26,56 & 10,94 & 23,44 & 100,00 \\
\hline & \multirow{2}{*}{ SCV } & Frequência & 35 & 1 & 22 & 1 & 5 & 64 \\
\hline & & Porcentagem & 54,69 & 1,56 & 34,38 & 1,56 & 7,81 & 100,00 \\
\hline & \multirow[b]{2}{*}{ SA } & Frequência & 2 & 0 & 57 & 0 & 5 & 64 \\
\hline & & Porcentagem & 3,13 & 0,00 & 89,06 & 0,00 & 7,81 & 100,00 \\
\hline \multirow{6}{*}{$\begin{array}{c}\text { Não } \\
\text { Motivada }\end{array}$} & \multirow{2}{*}{ SSV } & Frequência & 21 & 9 & 11 & 19 & 4 & 64 \\
\hline & & Porcentagem & 32,81 & 14,06 & 17,19 & 29,69 & 6,25 & 100,00 \\
\hline & \multirow{2}{*}{$\mathrm{SCV}$} & Frequência & 42 & 0 & 14 & 7 & 1 & 64 \\
\hline & & Porcentagem & 65,63 & 0,00 & 21,88 & 10,94 & 1,56 & 100,00 \\
\hline & \multirow{2}{*}{ SA } & Frequência & 11 & 1 & 50 & 0 & 2 & 64 \\
\hline & & Porcentagem & 17,19 & 1,56 & 78,13 & 0,00 & 3,13 & 100,00 \\
\hline \multirow{2}{*}{ Total } & & Frequência & 153 & 13 & 312 & 42 & 56 & 576 \\
\hline & & Porcentagem & 26,56 & 2,26 & 54,17 & 7,29 & 9,72 & 100,00 \\
\hline
\end{tabular}

Como podemos verificar, as crianças com níveis menos avançados (SSVC) são as que mais apresentam respostas não pertinentes (outra vogal, consoante próxima e consoante pertinente), e os SA, embora em menor quantidade, podem apresentar algumas respostas não pertinentes. É interessante observar que nesse nível conceitual nunca foi selecionada a consoante não pertinente, apesar de poderem utilizar consoantes próximas.

Somente em palavras não motivadas os SSVC usaram uma quantidade de consoantes não pertinentes (19 casos ou $26,69 \%)$ muito próxima à quantidade de vogais pertinentes (21 casos ou 32,81\%). Ou seja, dão mostras de não dispor de critérios estáveis para selecionar a letra inicial (característica própria de não utilizar letras de acordo com seu valor convencional). 
Contudo, essas mesmas crianças SSVC tiveram melhor desempenho com as palavras motivadas e de contraste no que diz respeito ao uso das consoantes próximas.

As crianças SCVC, nas palavras motivadas e de contraste, preferiram usar consoantes próximas a consoantes não pertinentes, salvo em palavras não motivadas.

A maior utilização das consoantes próximas sobre as consoantes não pertinentes é evidente, sobretudo em contexto de motivação e de contraste, indicando que as crianças, inclusive os SSVC, não escolhem suas respostas de maneira aleatória.

Nesse sentido, nos parece que foi mais simples completar iniciais de palavras motivadas e de contraste do que de não motivadas.

\subsubsection{Síntese dos resultados da tarefa de completar palavras}

Em síntese, encontramos um predomínio no uso de consoantes pertinentes para completar o início das palavras, sendo que a porcentagem maior de respostas por tipo de palavra sempre recaiu no uso de consoantes pertinentes. O grupo de palavras motivadas concentra a porcentagem maior de respostas corretas $(73,44 \%)$. Em segundo lugar, estariam as palavras com sílabas de contraste $(50 \%) \mathrm{e}$, finalmente, as palavras com sílabas iniciais não motivadas $(39,06 \%)$. Isso nos permite concluir que o fato de o nome da sílaba ter a mesma representação sonora que o da letra possibilitou melhor reconhecimento da letra correspondente.

Entre as palavras com início silábico motivado, chama-nos a atenção que, depois da escolha da consoante pertinente, o emprego de consoantes próximas seja a segunda opção mais utilizada. É provável que a composição da sílaba inicial em coincidência com o nome da letra restrinja as possibilidades de usar uma vogal para representar o início, pois o nome da letra que buscavam já está dado ao pronunciar-se a sílaba do início da palavra.

Em relação às palavras de contraste, metade das crianças completaram o início com a consoante pertinente, mas, à diferença do que fizeram com as palavras motivadas, a segunda opção mais utilizada foi a de empregar a vogal pertinente $(31,25 \%)$, mesmo que a escrita realizada resultasse na duplicação contígua de letras. Por exemplo: para TOMA, obtiveram [OOMA]. É interessante notar também que, apesar de muitas crianças conhecerem as consoantes "T", "P", "V" e "B", pois as utilizaram pertinentemente em contexto motivado, não puderam fazer uso dessas mesmas letras em outro contexto.

Essa preferência que se apresenta pelo uso das vogais se acentua nas palavras com início não motivado, chegando praticamente a apresentar equivalência com o uso de consoantes pertinentes (38.54\% vs. $39,06 \%$, respectivamente). 
Em relação ao nível de escrita, como era esperado, quanto mais avançado, maior a possibilidade de a criança escolher a letra correta. As crianças SA tiveram mais que o dobro de acertos que as crianças SSVSC e SCVSC no resultado total.

Por grupo de palavras esse padrão se mantém, mas a probabilidade de responder convencionalmente nos diferentes grupos de palavras mudou bastante em função do nível de escrita. Nas sílabas motivadas as crianças SA tiveram um desempenho 1,7 vezes maior que as crianças SSVSC e 1,3 vezes maior que as crianças SCVSC. Já no grupo das sílabas de contraste, o desempenho do SA em relação ao SSVSC foi 3,35 vezes maior e em relação ao SCVSC foi 2,5 vezes maior. No grupo das sílabas não motivadas, os SA foram 4,5 vezes melhores do que os SSVSC e 3,6 vezes melhores que o SCVSC.

Esses dados nos permitem perceber uma gradação na dificuldade implícita de cada grupo de palavras, sendo as não motivadas as mais complexas, uma vez que quanto menor a motivação, menor a possibilidade de acerto, sobretudo para os níveis menos avançados de escrita.

No entanto, a tarefa de completar palavras iniciadas por sílabas motivadas pode ser bastante simples para crianças silábicas. Elas fazem o recorte da sílaba oralmente e precisam apenas corresponder a parte (a sílaba) que recortam do oral com o respectivo nome da letra. É por isso que, embora soubessem o nome da letra (pois a utilizaram no contexto motivado), ao se depararem com o contexto de contraste não foram capazes de ter o mesmo desempenho: o contexto silábico que podiam identificar e recortar oralmente não correspondia necessariamente à alternativa convencional.

Na parte seguinte desse trabalho, verificaremos a influência de conhecer os nomes das letras para a sua utilização no contexto da tarefa de completar palavras e de escrever.

\subsection{Análise das respostas na tarefa de escrever e completar palavras segundo a possibilidade de identificar pertinentemente as letras fora de contexto}

Uma vez feita a análise da tarefa de identificação de letras fora do contexto, de escrita de palavras e de completar palavras, resta-nos analisar a influência da identificação de letras nas demais tarefas. Para isso, utilizamos a Correlação de Pearson. 
Tabela 66: Correlação de Pearson Identifica letras motivadas x escreve letras motivadas $\mathbf{x}$ escreve letras de contraste

\begin{tabular}{clccc}
\hline & Correlação de Pearson & $\begin{array}{c}\text { Identifica } \\
\text { Motivadas }\end{array}$ & $\begin{array}{c}\text { Total Escreve } \\
\text { Motivadas }\end{array}$ & $\begin{array}{c}\text { Total } \\
\text { Escreve } \\
\text { Contraste }\end{array}$ \\
\hline $\begin{array}{c}\text { Total Identifica } \\
\text { Motivadas }\end{array}$ & $\begin{array}{l}\text { Sig. (bilateral) } \\
\text { N }\end{array}$ & 1 &, $745^{* *}$ &, $618^{* *}$ \\
Total Escreve & Correlação de Pearson &, $745^{* *}$ &, 000 &, 000 \\
Motivadas & Sig. (bilateral) &, 000 & 48 & 48 \\
Total Escreve & Correlação de Pearson & 48 & 48 & \\
Contraste & Sig. (bilateral) &, $618^{* *}$ & & \\
& $\mathrm{~N}$ &, 000 & & 48 \\
\hline
\end{tabular}

* *A correlação é significativa no nível 0,01 (bilateral).

De acordo com a Correlação de Pearson, há uma forte correlação entre identificar letras motivadas e a possibilidade de utilizá-las em contexto de escrita de sílabas motivadas.

Em relação às letras motivadas e à possibilidade de utilizá-las em contexto de sílabas de contraste, verifica-se que a correlação existe, embora de maneira menos intensa que a correlação entre essas mesmas letras e o contexto motivado. Aqui a correlação é moderada, assim como a correlação entre identificar letras não motivadas e utilizá-las no momento da escrita:

Tabela 67: Correlação de Pearson Identifica letras não motivadas x escreve letras não motivadas

\begin{tabular}{clcc}
\hline & & \multicolumn{1}{c}{$\begin{array}{c}\text { Total } \\
\text { Identifica Não } \\
\text { Motivada }\end{array}$} & $\begin{array}{c}\text { Total Escreve } \\
\text { Não } \\
\text { Motivada }\end{array}$ \\
\hline Total Identifica Não \\
Motivada & $\begin{array}{l}\text { Correlação de Pearson } \\
\text { Sig. (bilateral) }\end{array}$ & 1 &, $533^{* *}$ \\
& $\mathrm{~N}$ & 48 &, 000 \\
Total Escreve Não Motivada & Correlação de Pearson &, $533^{* *}$ & 48 \\
& Sig. (bilateral) &, 000 & 1 \\
& $\mathrm{~N}$ & 48 & 48 \\
\hline
\end{tabular}

* *A correlação é significativa no nível 0,01 (bilateral). 
$\mathrm{Na}$ tarefa de completar palavras observamos também uma forte correlação entre identificar as letras motivadas e poder utilizá-las no contexto de completar sílabas de contraste, e uma correlação moderada entre identificar letras motivadas e completar sílabas motivadas.

Tabela 68: Correlação de Pearson identifica letras motivadas x completa sílabas motivadas e de contraste

\begin{tabular}{|c|c|c|c|c|}
\hline & & $\begin{array}{l}\text { Identifica } \\
\text { Motivadas }\end{array}$ & $\begin{array}{c}\text { Total } \\
\text { Completa } \\
\text { Motivadas } \\
\end{array}$ & $\begin{array}{c}\text { Total } \\
\text { Completa } \\
\text { Contraste } \\
\end{array}$ \\
\hline \multirow{3}{*}{ Total Identifica Motivadas } & Correlação de Pearson & 1 &, $529 * *$ &, $672 * *$ \\
\hline & Sig. (bilateral) & &, 000 &, 000 \\
\hline & $\mathrm{N}$ & 48 & 48 & 48 \\
\hline \multirow{3}{*}{ Total Completa Motivadas } & Correlação de Pearson &, $529 * *$ & 1 & \\
\hline & Sig. (bilateral) &, 000 & & \\
\hline & $\mathrm{N}$ & 48 & 48 & \\
\hline \multirow{3}{*}{ Total Completa Contraste } & Correlação de Pearson &, $672 * *$ & & 1 \\
\hline & Sig. (bilateral) &, 000 & & \\
\hline & $\mathrm{N}$ & 48 & & 48 \\
\hline
\end{tabular}

* *A correlação é significativa no nível 0,01 (bilateral).

Já entre as letras não motivadas, observamos uma fraca correlação entre identificar letras não motivadas e a possibilidade de utilizá-las no contexto de completar palavras não motivadas.

Tabela 69: Correlação de Pearson identifica letras não motivadas x completa sílabas não motivadas

\begin{tabular}{|c|c|c|c|}
\hline & & $\begin{array}{c}\text { Total } \\
\begin{array}{c}\text { Identifica Não } \\
\text { Motivada }\end{array} \\
\end{array}$ & $\begin{array}{l}\text { Total Escreve } \\
\text { Não Motivada }\end{array}$ \\
\hline \multirow{3}{*}{$\begin{array}{c}\text { Total Identifica Não } \\
\text { Motivada }\end{array}$} & Correlação de Pearson & 1 & ,455** \\
\hline & Sig. (bilateral) & &, 001 \\
\hline & $\mathrm{N}$ & 48 & 48 \\
\hline \multirow{3}{*}{$\begin{array}{c}\text { Total Escreve Não } \\
\text { Motivada }\end{array}$} & Correlação de Pearson & $455 * *$ & 1 \\
\hline & Sig. (bilateral) & 001 & \\
\hline & $\mathrm{N}$ & 48 & 48 \\
\hline
\end{tabular}

**A correlação é significativa no nível 0,01 (bilateral).

\subsubsection{Análise das respostas na tarefa de escrever e completar palavras das crianças que identificaram pertinentemente as letras}

Ao analisarmos minuciosamente, entre os grupos de palavras e segundo o nível de escrita, conseguimos observar claramente que a probabilidade de identificar letras motivadas e utilizá-las tanto no contexto de escrita quanto no de completar palavras aumenta em função do 
nível de escrita. A quantidade de respostas pertinentes aumenta conforme aumenta o nível de escrita, e o inverso ocorre em relação às respostas não pertinentes.

Tabela 70: Frequências e Porcentagens de respostas nas tarefas de escrever e completar palavras motivadas, das crianças que identificaram as letras motivadas ${ }^{30}$

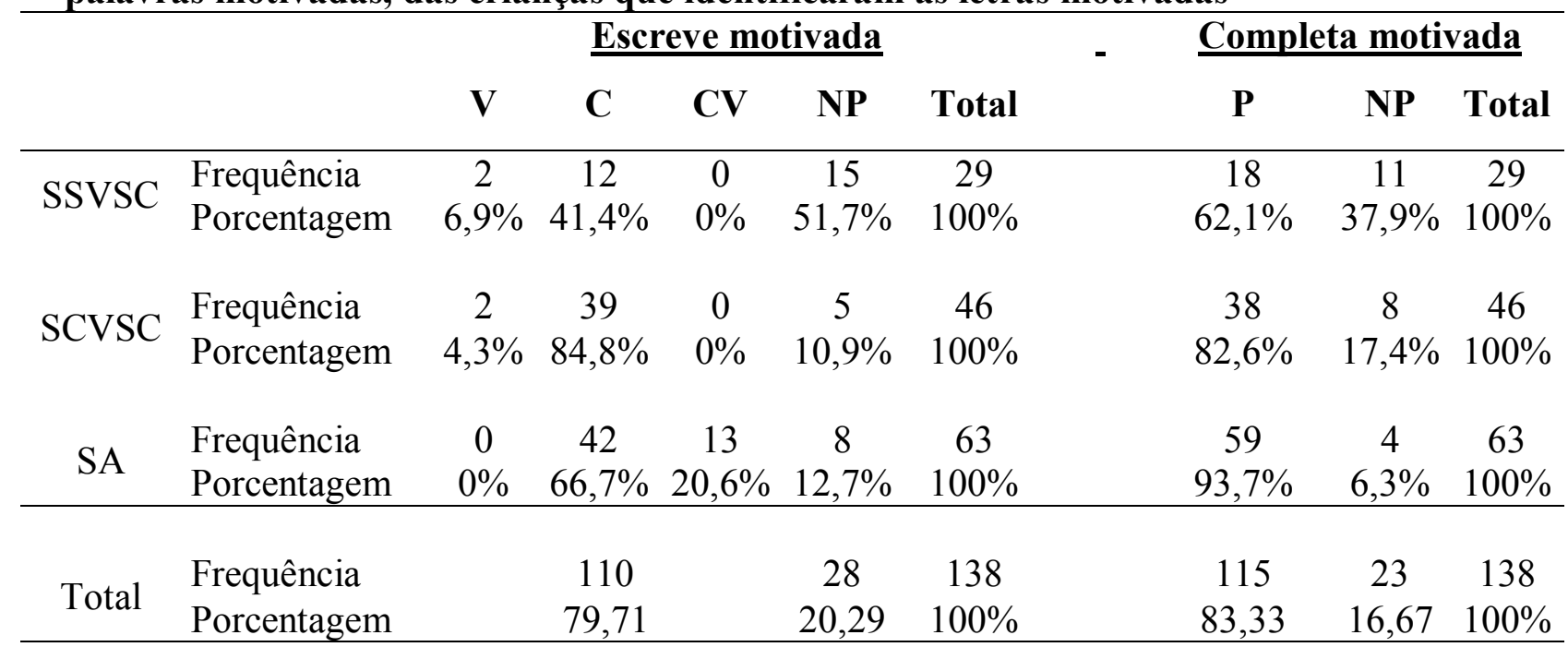

Como mostra a Tabela 70, as crianças que identificaram as letras V, T, P e B foram capazes de escrever pertinentemente $79,71 \%$ das sílabas motivadas. Para escrever utilizaram majoritariamente a respectiva consoante, independentemente do nível de escrita. Porém, a motivação fonológica não mostrou favorecer a escrita convencional da sílaba motivada $(\mathrm{CV})$, visto que apenas $20,6 \%$ das crianças SA conseguiram utilizar essa representação no contexto motivado. Podemos concluir que se a coincidência entre o contexto motivado e o nome da letra por um lado favoreceu a escrita, utilizando a respectiva consoante, por outro, prejudicou a possibilidade do registro mais conceitualmente avançado $(\mathrm{CV})$.

As crianças que identificaram as letras motivadas também se mostraram bastante aptas a completar as palavras $(83,33 \%)$. Esse resultado não surpreende, haja vista que as crianças desse nível conceitual (silábico) têm condição de fazer o recorte silábico da palavra. Como as sílabas iniciais desse grupo de palavras coincidiam com os nomes das letras, ao pronunciar a sílaba, a criança dizia o nome da letra, e, uma vez que ela conseguia identificar as letras por seus nomes, localizá-las para completar as palavras desse grupo não representou um grande desafio. Vemos que mesmo entre as crianças SSVSC, das 29 que identificaram a letra por seu nome, $62 \%$ puderam utilizá-la para completar palavras.

\footnotetext{
${ }^{30}$ A título de organização da tabela, foram usadas as seguintes siglas: V (vogal), C (consoante), CV (consoantevogal), NP (resposta não pertinente), e P (resposta pertinente).
} 
Para as crianças desse nível conceitual, a tarefa de completar palavras pareceu ser mais fácil que a tarefa de escrever. Na tarefa de completar, $62 \%$ conseguiram escolher a respectiva letra, no entanto, na tarefa de escrita pouco mais da metade das crianças que identificaram as letras corretamente $(51,7 \%)$ produziu escritas não pertinentes; se incluirmos a escolha pela vogal no grupo de respostas não pertinentes na tarefa de escrita, teríamos que 58,6\% produziram escritas que não faziam uso da consoante. Portanto, embora $62,1 \%$ tenham sido capazes de utilizar a consoante na tarefa de completar, apenas $41,4 \%$ foram capazes de utilizar a mesma consoante na tarefa de escrita.

As sílabas de contraste eram compostas pelas letras motivadas, mas em um contexto silábico em que o nome da sílaba não coincidisse com o nome da consoante que a compunha. Como mostra a Tabela 71, as crianças que identificaram as letras V, T, P e B foram capazes de escrever pertinentemente $73,91 \%$ das sílabas de contraste.

Tabela 71: Frequências e Porcentagens de respostas nas tarefas de escrever e completar palavras de contraste, das crianças que identificaram as letras motivadas

\begin{tabular}{|c|c|c|c|c|c|c|c|c|c|}
\hline & \multicolumn{5}{|c|}{ Escreve contraste } & \multicolumn{3}{|c|}{ Completa contraste } \\
\hline & & V & $\mathbf{C}$ & $\mathrm{CV}$ & $\mathbf{N P}$ & Total & $\mathbf{P}$ & NP & Total \\
\hline \multirow{2}{*}{ SSVSC } & Frequência & 5 & 3 & 0 & 21 & 29 & 11 & 18 & 29 \\
\hline & Porcentagem & $17,2 \%$ & $10,3 \%$ & $0 \%$ & $72,4 \%$ & $100 \%$ & $37,9 \%$ & $62,1 \%$ & $100 \%$ \\
\hline \multirow{2}{*}{ SCVSC } & Frequência & 24 & 12 & 3 & 7 & 46 & 20 & 26 & 46 \\
\hline & Porcentagem & $52,2 \%$ & $26,1 \%$ & $6,5 \%$ & $15,2 \%$ & $100 \%$ & $43,5 \%$ & $56,5 \%$ & $100 \%$ \\
\hline \multirow{2}{*}{ SA } & Frequência & 2 & 6 & 47 & 8 & & 57 & 6 & 63 \\
\hline & Porcentagem & $3,2 \%$ & $9,5 \%$ & $74,6 \%$ & $12,7 \%$ & $100 \%$ & $90,5 \%$ & $9,5 \%$ & $100 \%$ \\
\hline \multirow[b]{2}{*}{ Total } & Frequência & & 102 & & 36 & 138 & 88 & 50 & 138 \\
\hline & Porcentagem & & 73,91 & & 26,09 & $100 \%$ & 63,77 & 36,23 & $100 \%$ \\
\hline
\end{tabular}

Nesse grupo de palavras, a escrita da $1^{\mathrm{a}}$ sílaba esteve distribuída de forma mais equilibrada entre as categorias de resposta. No entanto, para escrever, o tipo de representação mais utilizado pelas crianças que identificaram pertinentemente as letras desse grupo foi a $\mathrm{CV}$, alavancado, sobretudo, pelas crianças SA. O dado de que $74,6 \%$ das crianças SA que identificaram as letras tiveram condições de escrever convencionalmente a sílaba no contexto de contraste corrobora com a ideia levantada anteriormente de que para esse grupo conceitual a motivação fonológica da sílaba não favoreceu o desempenho. Esses dados permitem a conclusão de que não foi o conhecimento do nome da letra e a coincidência com o contexto silábico que possibilitaram a escrita mais convencional, mas sim que o nível conceitual está condicionando o uso que a criança pode fazer da informação sobre os nomes das letras. 
Vale destacar que a sílaba só será motivada fonologicamente, do ponto de vista da criança, se ela souber os nomes das respectivas letras.

Em relação à tarefa de completar palavras, as crianças que identificaram as letras motivadas tiveram um desempenho inferior quando comparado ao contexto motivado, ainda que $63,77 \%$ das respostas tenham sido pertinentes. Vemos que a probabilidade das crianças SSVSC se inverteu, sendo que $62,1 \%$ de suas respostas foram não pertinentes; os SCVSC tiveram praticamente a mesma quantidade de respostas pertinentes e não pertinentes, ocorrendo um incremento importante nas não pertinentes (56,5\%); e para os SA, ainda que tenha ocorrido uma queda no desempenho em relação ao contexto motivado, foi apenas de $3 \%$.

Entre as crianças que identificaram as letras não motivadas ( $\mathrm{R}, \mathrm{L}, \mathrm{M}$ e N), embora não seja observada diferença significativa entre os totais de respostas pertinentes na tarefa de escrita entre os três grupos, notamos que para a escrita das sílabas não motivadas houve um deslocamento das respostas da categoria consoante para a categoria vogal.

Assim como ocorreu com as sílabas de contraste, observamos que as crianças SA que identificaram as letras não motivadas tiveram maior quantidade de respostas convencionas $(73,4 \%)$. Para os demais níveis conceituais, as respostas da tarefa de escrita se concentraram ou na categoria não pertinente (67,7\% - SSVSC) ou na categoria das vogais (68,2\% - SCVSC), mostrando que apesar de reconhecerem as letras, não puderam fazer uso delas no contexto de escrita.

Tabela 72: Frequências e Porcentagens de respostas nas tarefas de escrever e completar palavras de contraste, das crianças que identificaram letras não motivadas

\begin{tabular}{|c|c|c|c|c|c|c|c|c|c|}
\hline & \multicolumn{5}{|c|}{ Escreve não motivada } & \multicolumn{3}{|c|}{ Completa não motivada } \\
\hline & & V & $\mathbf{C}$ & $\mathbf{C V}$ & NP & Total & $\mathbf{P}$ & $\mathbf{N P}$ & Total \\
\hline \multirow{2}{*}{ SSVSC } & Frequência & 10 & 0 & 0 & 21 & 31 & 6 & 25 & 31 \\
\hline & Porcentagem & $32,3 \%$ & $0 \%$ & $0 \%$ & $67,7 \%$ & $100,0 \%$ & $19,4 \%$ & $80,6 \%$ & $100 \%$ \\
\hline \multirow{2}{*}{$\begin{array}{c}\text { SCVS } \\
\text { C }\end{array}$} & Frequência & 30 & 6 & 0 & 8 & 44 & 13 & 31 & 44 \\
\hline & Porcentagem & $68,2 \%$ & $13,6 \%$ & $0,0 \%$ & $18,2 \%$ & $100,0 \%$ & $29,5 \%$ & $70,5 \%$ & $100 \%$ \\
\hline \multirow{2}{*}{ SA } & Frequência & 5 & 5 & 47 & 7 & 64 & 50 & 14 & 64 \\
\hline & Porcentagem & $7,8 \%$ & $7,8 \%$ & $73,4 \%$ & $10,9 \%$ & $100 \%$ & $78,1 \%$ & $21,9 \%$ & $100 \%$ \\
\hline \multirow[b]{2}{*}{ Total } & Frequência & & 103 & & 36 & 142 & 69 & 70 & 139 \\
\hline & Porcentagem & & 74,64 & & 26,09 & $100 \%$ & 50,00 & 50,72 & $100 \%$ \\
\hline
\end{tabular}

$\mathrm{Na}$ tarefa de completar palavras do grupo iniciado por sílabas "não motivadas fonologicamente", as respostas das crianças SSVSC (80,6\%) e SCVSC (70,5\%) concentraram- 
se na categoria "não pertinente". Mesmo as crianças SA tiveram um incremento das respostas não pertinentes em comparação com as outras categorias de palavras.

Esses dados parecem indicar que, apesar das sílabas de contraste e não motivadas possibilitarem uma escrita mais convencional por parte das crianças SA, a possibilidade de relacionar a letra que falta para completar uma sílaba é menor do que a de escrever a mesma sílaba, mesmo sabendo o nome da letra e a tendo usado no momento de escrever.

O fato das Tabelas 70, 71 e 72 serem compostas somente por crianças que identificaram pertinentemente as letras que foram foco de análise nos distintos grupos de palavras nos mostra que saber o nome convencional da letra não foi o fator determinante para garantir a pertinência da resposta. Isso porque, apesar de observarmos comportamentos de resposta que variavam em função da motivação fonológica, o denominador comum que implicava no incremento das respostas não foi saber ou não o nome da letra, visto que nos agrupamentos propostos todas sabiam, nem a coincidência com o contexto fonológico, mas sim o nível conceitual da criança.

\subsubsection{Análise das respostas na tarefa de escrever e completar palavras das crianças que não identificaram letras}

Ao observar a distribuição das respostas das crianças que não identificaram as letras da sílaba inicial nas tarefas de completar e escrever palavras, tanto nos contextos motivado e de contraste $(\mathrm{V}, \mathrm{T}, \mathrm{P}, \mathrm{B})$, quanto no contexto não motivado $(\mathrm{R}, \mathrm{L}, \mathrm{M}, \mathrm{N})$, vemos que ainda que não tivessem identificado a respectiva letra, houve crianças que puderam produzir escritas pertinentes e completar pertinentemente as palavras.

Como o índice de identificação de letras para todos os grupos foi bastante grande, a quantidade de respostas para essa análise foi baixa, porém, a observação desses dados ajuda a compor as análises realizadas nas outras tarefas.

Como mostra a Tabela 73, 38\% das escritas motivadas foram realizadas de forma pertinente, embora tenham sido produzidas por crianças que não identificaram nenhuma das letras motivadas utilizadas na tarefa de escrita. Notamos que esse contexto silábico não foi favorável para que as crianças que não conheciam as respectivas letras produzissem escritas convencionais $(\mathrm{CV})$ - mesmo no nível mais avançado de reflexão sobre o sistema. Mais um dado que ajuda a corroborar a ideia de que não é o conhecimento isolado do nome da letra, tampouco o contexto silábico isoladamente, o que favoreceria a produção de escritas convencionais ou mesmo pertinentes, mas sim a possibilidade de a criança estabelecer relações entre a informação e sua utilidade em função dos diferentes contextos. Essa possibilidade, por 
sua vez, é estreitamente ligada à reflexão que a criança é capaz de fazer sobre o sistema de escrita.

No nível SSVSC, houve 32 casos em que as letras motivadas não foram identificadas e em $84 \%$ das vezes as crianças produziram escritas não pertinentes. No entanto, na tarefa de completar palavras a quantidade de respostas pertinentes e não pertinentes foi equilibrada $(50 \%)$.

Esse resultado chama a atenção, pois na análise realizada entre as crianças que identificaram as letras motivadas vimos que $62 \%$ das respostas para completar a sílaba foram pertinentes (Tabela 70) e levantamos a hipótese de que o conhecimento do nome da letra teve influência nesse contexto fonológico, no desempenho da tarefa. No entanto, o fato de que $50 \%$ das respostas foram pertinentes, embora tivessem sido produzidas por crianças que não reconheceram as letras motivadas, ajuda a corroborar a hipótese de que o conhecimento iso lado do nome da letra nem sempre é uma informação que a criança utiliza ou de que necessita para realizar a tarefa de completar palavras em contextos motivados, nos quais há perfeita coincidência entre o nome da letra e o valor da sílaba.

Observar o conjunto de respostas pertinentes segundo os grupos de palavras também permite verificar um dado interessante: ao contrário do que ocorreu com as respostas produzidas pelas crianças que identificaram pertinentemente as letras, em que o desempenho na tarefa de escrita diminuía conforme diminuía a relação fonológica (quanto menor a motivação fonológica, menos respostas pertinentes), entre as crianças que não identificaram as letras vemos que a quantidade de respostas pertinentes aumentou em função da diminuição da motivação fonológica (o desempenho foi melhor no grupo de palavras não motivadas, seguido pelo grupo de contraste e, por fim, pelo grupo de palavras motivadas). Já na tarefa de completar palavras a motivação fonológica parece ter influenciado na probabilidade de responder de forma pertinente, tanto entre os que identificaram as letras quanto entre os que não as identificaram. 
Tabela 73: Frequências e Porcentagens de respostas nas tarefas de escrever e completar palavras motivadas, de contraste e não motivadas, das crianças que não identificaram letras

\begin{tabular}{|c|c|c|c|c|c|c|c|c|c|c|c|c|c|c|c|c|c|c|c|c|c|c|c|c|}
\hline & \multicolumn{5}{|c|}{ Escreve motivada } & \multicolumn{3}{|c|}{ Completa motivada } & \multicolumn{5}{|c|}{ Escreve contraste } & \multicolumn{3}{|c|}{ Completa contraste } & \multicolumn{5}{|c|}{ Escreve não motivada } & \multicolumn{3}{|c|}{$\frac{\text { Completa não }}{\text { motivada }}$} \\
\hline & V & $\mathrm{C}$ & CV & NP & Total & $P$ & NP & Total & V & C & $\mathrm{CV}$ & NP & Total & $P$ & NP & Total & V & C & $\mathrm{CV}$ & NP & Total & $P$ & NP & Total \\
\hline \multirow{2}{*}{ SSVSC } & 3 & 2 & 0 & 27 & 32 & 16 & 16 & 32 & 10 & 0 & 0 & 22 & 32 & 5 & 27 & 32 & 5 & 1 & 0 & 24 & 30 & 3 & 27 & 30 \\
\hline & $9 \%$ & $6 \%$ & $0 \%$ & $84 \%$ & $100 \%$ & $50 \%$ & $50 \%$ & $100 \%$ & $31 \%$ & $0 \%$ & $0 \%$ & $69 \%$ & $100 \%$ & $16 \%$ & $84 \%$ & $100 \%$ & $17 \%$ & $3 \%$ & $0 \%$ & $80 \%$ & $100 \%$ & $10 \%$ & $90 \%$ & $100 \%$ \\
\hline \multirow{2}{*}{ SCvsC } & 6 & 7 & 0 & 4 & 17 & 7 & 10 & 17 & 12 & 3 & 0 & 2 & 17 & 2 & 15 & 17 & 18 & 0 & 0 & 2 & 20 & 1 & 19 & 20 \\
\hline & $35 \%$ & $41 \%$ & $0 \%$ & $24 \%$ & $100 \%$ & $41 \%$ & $59 \%$ & $100 \%$ & $71 \%$ & $18 \%$ & $0 \%$ & $12 \%$ & $100 \%$ & $12 \%$ & $88 \%$ & $100 \%$ & $90 \%$ & $0 \%$ & $0 \%$ & $10 \%$ & $100 \%$ & $5 \%$ & $95 \%$ & $100 \%$ \\
\hline SA & $\begin{array}{c}0 \\
0 \%\end{array}$ & $\begin{array}{c}1 \\
100 \%\end{array}$ & $\begin{array}{c}0 \\
0 \%\end{array}$ & $\begin{array}{c}0 \\
0 \%\end{array}$ & $\begin{array}{c}1 \\
100 \%\end{array}$ & $\begin{array}{c}1 \\
100 \%\end{array}$ & $\begin{array}{c}0 \\
0 \%\end{array}$ & $\begin{array}{c}1 \\
100 \%\end{array}$ & $\begin{array}{c}0 \\
0 \%\end{array}$ & $\begin{array}{c}0 \\
0 \%\end{array}$ & $\begin{array}{c}1 \\
100 \%\end{array}$ & $\begin{array}{c}0 \\
0 \%\end{array}$ & $\begin{array}{c}1 \\
100 \%\end{array}$ & $\begin{array}{c}0 \\
0 \%\end{array}$ & $\begin{array}{c}1 \\
100 \%\end{array}$ & $\begin{array}{c}1 \\
100 \%\end{array}$ & $\begin{array}{c}0 \\
\text { N/A }\end{array}$ & $\begin{array}{c}0 \\
\text { N/A }\end{array}$ & $\begin{array}{c}0 \\
0\end{array}$ & $\begin{array}{c}0 \\
N / A\end{array}$ & $0 \%$ & $\begin{array}{c}0 \\
0 / 4\end{array}$ & $\begin{array}{c}0 \\
N / A\end{array}$ & $0 \%$ \\
\hline Total & & $\begin{array}{c}19 \\
38 \%\end{array}$ & & $\begin{array}{c}31 \\
62 \%\end{array}$ & $\begin{array}{c}50 \\
100 \%\end{array}$ & $\begin{array}{c}24 \\
48 \%\end{array}$ & $\begin{array}{c}26 \\
52 \%\end{array}$ & $\begin{array}{c}50 \\
100 \%\end{array}$ & & $\begin{array}{c}26 \\
52 \%\end{array}$ & & $\begin{array}{c}24 \\
48 \%\end{array}$ & $\begin{array}{c}50 \\
100 \%\end{array}$ & $\begin{array}{c}7 \\
14 \%\end{array}$ & $\begin{array}{c}43 \\
86 \%\end{array}$ & $\begin{array}{c}50 \\
100 \%\end{array}$ & & $\begin{array}{c}24 \\
48 \%\end{array}$ & & $\begin{array}{c}26 \\
52 \%\end{array}$ & $\begin{array}{c}50 \\
100 \%\end{array}$ & $\begin{array}{c}4 \\
8 \%\end{array}$ & $\begin{array}{c}46 \\
92 \%\end{array}$ & $\begin{array}{c}50 \\
100 \%\end{array}$ \\
\hline
\end{tabular}

Entre as crianças SA apenas uma não reconheceu uma das letras motivadas, no entanto, é interessante notar como essa única resposta isolada é bastante representativa das respostas produzidas por esse nível conceitual, pois se comporta de modo muito semelhante às análises realizadas anteriormente a respeito das respostas produzidas pelas crianças desse nível. Embora essa criança não tivesse reconhecido a letra durante a tarefa de identificação de letras fora do contexto, ela foi capaz de utilizá-la pertinentemente no momento da escrita, produzindo uma escrita silábica.

\subsection{Análise qualitativa multivariada dos dados}

Nesta parte apresentaremos a última perspectiva da análise dos dados, na qual retomaremos e cruzaremos as respostas das crianças participantes para as tarefas realizadas (identificação de letras fora do contexto, escrita da sílaba inicial de palavras e completar palavras).

Para isso, para poder coordenar as respostas entre si, as reclassificamos da seguinte maneira: 
Tabela 74: Classificação segundo os tipos de respostas

\begin{tabular}{|c|c|c|}
\hline SIGLA & Descrição & Exemplo \\
\hline IEC & $\begin{array}{l}\text { Respostas em que as crianças } \\
\text { identificaram pertinentemente as letras } \\
\text { (fora de contexto), escreveram e } \\
\text { completaram palavras com a respectiva } \\
\text { letra identificada }\end{array}$ & $\begin{array}{l}\text { Identificou T e a usou para escrever a sílaba } \\
\text { inicial em TEMIDA e/ou TOMADA e a } \\
\text { usou para completar TEMA e/ou TOMA }\end{array}$ \\
\hline IC & $\begin{array}{l}\text { Respostas em que as crianças } \\
\text { identificaram pertinentemente as letras } \\
\text { (fora do contexto) e completaram a palavra }\end{array}$ & $\begin{array}{l}\text { Identificou } \mathrm{T} \text { e a usou para completar } \\
\text { TEMA e/ou TOMA, mas não para escrever } \\
\text { (TEMIDA e/ou TOMADA) }\end{array}$ \\
\hline IE & $\begin{array}{l}\text { Respostas em que as crianças } \\
\text { identificaram pertinentemente as letras } \\
\text { (fora do contexto) e escreveram a sílaba } \\
\text { inicial da palavra (que coincidia com a } \\
\text { inicial) }\end{array}$ & $\begin{array}{l}\text { Identificou } T \text { e a usou para escrever a sílaba } \\
\text { inicial em TEMIDA e/ou TOMADA, mas } \\
\text { não usou para completar (TEMA e/ou } \\
\text { TOMA) }\end{array}$ \\
\hline $\mathrm{EC}$ & $\begin{array}{l}\text { Respostas em que as crianças escreveram } \\
\text { pertinentemente a sílaba inicial de uma } \\
\text { palavra e completaram outra palavra } \\
\text { iniciada com a respectiva letra. }\end{array}$ & $\begin{array}{l}\text { Escreveu T em TEMIDA e/ou TOMADA e } \\
\text { completou T em TEMA e/ou TOMA }\end{array}$ \\
\hline I & $\begin{array}{l}\text { Respostas em que as crianças apenas } \\
\text { identificaram pertinentemente as letras } \\
\text { fora do contexto }\end{array}$ & $\begin{array}{l}\text { Identificaram } \mathrm{T} \text {, mas não usaram para } \\
\text { escrever ou completar palavras iniciadas } \\
\text { com a respectiva letra }\end{array}$ \\
\hline $\mathrm{C}$ & $\begin{array}{l}\text { Respostas em que as crianças somente } \\
\text { completaram pertinentemente palavra } \\
\text { agregando a inicial }\end{array}$ & $\begin{array}{l}\text { Completou } \mathrm{T} \text {, mas não identificou a letra } \\
\text { fora de contexto e não a usou para escrever } \\
\text { palavras iniciadas com a respectiva letra. }\end{array}$ \\
\hline $\mathrm{E}$ & $\begin{array}{l}\text { Respostas em que as crianças somente } \\
\text { escreveram a letra inicial da palavra } \\
\text { utilizando pelo menos uma consoante de } \\
\text { maneira pertinente }\end{array}$ & $\begin{array}{l}\text { Escreveu T ou TE para TEMIDA e/ou T ou } \\
\text { TO para TOMADA, mas não identificou a } \\
\text { letra fora do contexto e não a utilizou para } \\
\text { completar palavra iniciadas com a mesma } \\
\text { letra. }\end{array}$ \\
\hline $\mathrm{N}$ & $\begin{array}{l}\text { Quando as respostas das crianças não } \\
\text { foram pertinentes. }\end{array}$ & $\begin{array}{l}\text { Não identificou as letras fora de contexto, } \\
\text { nem completou, nem escreveu a sílaba } \\
\text { inicial de maneira pertinente }\end{array}$ \\
\hline
\end{tabular}


Partindo dessa lógica, os dados gerais por nível de escrita se apresentam a seguir:

Tabela 75: Frequência de respostas coordenadas, por nível de escrita

\begin{tabular}{lcccccccc}
\hline $\begin{array}{l}\text { Nível de } \\
\text { escrita }\end{array}$ & IEC & IC & IE & EC & I & C & E & N \\
\hline SSVSC & 11 & 16 & 1 & 0 & 31 & 17 & 3 & 38 \\
SCVSC & 41 & 12 & 5 & 7 & 35 & 2 & 3 & 19 \\
SA & 102 & 9 & 12 & 1 & 1 & 0 & 0 & 0 \\
\hline Total & 154 & 37 & 18 & 8 & 67 & 19 & 6 & 57 \\
\hline
\end{tabular}

A partir desses dados, podemos assinalar que as respostas mais coordenadas (Identificar, Escrever e Completar palavras pertinentemente - IEC) foram diretamente proporcionais ao nível de escrita, de maneira que as crianças com menor nível de escrita (SSVC) apresentaram somente 11 respostas deste tipo e as crianças mais avançadas (SA), 102.

A respeito dos resultados em que se coordenaram respostas pertinentes em duas tarefas (IC, IC, EC), observamos que, em conjunto, estas foram menores (63 frequências) do que as respostas que não conseguiram apresentar pertinência em mais que uma tarefa (I, C, E - 92 frequências).

As menos frequentes foram as $\mathrm{N}$, em que as crianças não responderam com pertinência nenhuma tarefa. Sobre este tipo de resposta coordenada, é importante assinalar que foram inversamente proporcionais ao nível de escrita, de maneira que as crianças com escrita SSVC foram as que apresentaram maior quantidade desse tipo de resposta (38 frequências). As crianças SA não apresentaram esse tipo de resposta.

Colocando como foco de análise os participantes e a consistência do conjunto de suas respostas, atribuímos pontuações baseadas na quantidade de tarefas resolvidas com pertinência. A pontuação foi a seguinte: 
Tabela 76: Pontuação atribuída segundo os tipos de respostas

Tipos de respostas

\section{Pontuação atribuída}

IEC Somamos o número de casos de respostas deste tipo e multiplicamos por 100

IC, IE Somamos o número de casos de respostas deste tipo e multiplicamos por 10

I, C, E Demos um ponto para cada caso de resposta deste tipo

$\mathrm{N}$ Demos um ponto para cada caso de resposta deste tipo, mas não acumulamos à contagem de respostas pertinentes

Partindo desse esquema, a pontuação máxima que um participante poderia obter seria 800, considerando que esteve exposto à realização de 3 tarefas (100 pontos por haver apresentado respostas pertinentes para as 3), com 8 letras diferentes. As pontuações máximas de $\mathrm{N}$ poderiam ser de até 8 . Apresentamos, a seguir, um exemplo de como interpretar a pontuação dada a um de nossos participantes:

O participante SS04 (com escrita silábica sem valor sonoro convencional) obteve uma pontuação de 321 pontos. O que significa que em três ocasiões pôde responder pertinentemente à identificação de uma letra, que posteriormente a utilizou para escrever a sílaba inicial de uma palavra e para completar o início de outra (300 pontos). Porém, somente pôde coordenar duas tarefas para duas letras (20 pontos), e apenas uma resposta pertinente para alguma das letras (1 ponto).

É importante destacar que para esta análise não consideramos os contextos (motivados ou não motivados) nos quais se produziram as respostas. Bastou que uma criança emitisse ao menos uma das respostas pertinentes (pela letra e tarefa) para que a contabilizássemos como 1 ponto. Quando emitiu duas respostas pertinentes, por exemplo, ao completar palavras motivadas e de contraste com "T", consideramos como uma resposta pertinente, ou mesmo quando completou com "T" apenas um dos contextos. Na Tabela 77, listamos a pontuação total, segundo o nível de escrita, de cada participante: 
Tabela 77: Pontuação total e $\mathbf{N}$ por participantes, por nível de escrita

\begin{tabular}{ccccccccc}
\hline $\begin{array}{c}\text { Participantes } \\
\text { SSVSC }\end{array}$ & $\begin{array}{c}\text { Pontuação } \\
\text { Total }\end{array}$ & N & $\begin{array}{c}\text { Participantes } \\
\text { SCVSC }\end{array}$ & $\begin{array}{c}\text { Pontuação } \\
\text { Total }\end{array}$ & N & $\begin{array}{c}\text { Participant } \\
\text { es SA }\end{array}$ & $\begin{array}{c}\text { Pontuação } \\
\text { Total }\end{array}$ & N \\
\hline SS01 & 123 & 2 & SC01 & 413 & 0 & SA01 & 701 & 0 \\
SS02 & 2 & 4 & SC02 & 413 & 0 & SA02 & 602 & 0 \\
SS03 & 35 & 1 & SC03 & 512 & 0 & SA03 & 800 & 0 \\
SS04 & 321 & 1 & SC04 & 323 & 0 & SA04 & 502 & 0 \\
SS05 & 44 & 0 & SC05 & 17 & 4 & SA05 & 701 & 0 \\
SS06 & 25 & 1 & SC06 & 26 & 0 & SA06 & 404 & 0 \\
SS07 & 5 & 3 & SC07 & 314 & 0 & SA07 & 701 & 0 \\
SS08 & 12 & 5 & SC08 & 224 & 0 & SA08 & 503 & 0 \\
SS09 & 3 & 5 & SC09 & 233 & 2 & SA08 & 504 & 0 \\
SS10 & 1 & 6 & SC10 & 123 & 2 & SA10 & 602 & 0 \\
SS11 & 2 & 5 & SC11 & 314 & 0 & SA11 & 701 & 0 \\
SS12 & 105 & 1 & SC12 & 611 & 0 & SA12 & 701 & 0 \\
SS13 & 215 & 0 & SC13 & 7 & 5 & SA13 & 800 & 0 \\
SS14 & 304 & 1 & SC14 & 124 & 3 & SA14 & 800 & 0 \\
SS15 & 4 & 3 & SC15 & 512 & 0 & SA15 & 503 & 0 \\
SS16 & 103 & 1 & SC16 & 233 & 2 & SA16 & 701 & 0 \\
\hline
\end{tabular}

E na Tabela 78, reunimos a pontuação segundo o nível de escrita:

Tabela 78: Pontuação segundo nível de escrita e intervalo numérico

\begin{tabular}{lccc}
\hline Participantes & $\begin{array}{c}\text { Pontuação } \\
\text { SSVS }\end{array}$ & $\begin{array}{c}\text { Pontuação } \\
\text { SCVS }\end{array}$ & $\begin{array}{c}\text { Pontuação } \\
\text { SA }\end{array}$ \\
\hline $\begin{array}{l}\text { Participantes no } \\
\text { intervalo das } \\
\text { centenas }\end{array}$ & 6 & 13 & 16 \\
$\begin{array}{l}\text { Participantes no } \\
\text { intervalo das } \\
\text { dezenas }\end{array}$ & 7 & 15 & 0 \\
$\begin{array}{l}\text { Participantes no } \\
\text { intervalo das } \\
\text { unidades }\end{array}$ & 16 & 16 & 13 \\
\hline
\end{tabular}

As crianças com escritas mais avançadas (SA), ainda que prioritariamente tenham conseguido coordenar as três tarefas realizadas, puderam apresentar (13 participantes) respostas não coordenadas no intervalo das unidades. 
As crianças com escritas intermediárias (SCVSC), ainda que também apresentassem pontuações no intervalo das centenas (13 participantes), não ultrapassaram os 600 pontos. A maioria (6 participantes) apresentou pontuações entre 300 e 200, e somente 5 participantes ultrapassaram os 400 pontos. No entanto, 15 dos 16 participantes desse grupo apresentaram coordenação entre duas tarefas pelo menos em uma ocasião.

Todas as crianças com escritas SCVSC apresentaram respostas pertinentes somente em uma tarefa (marcadas no intervalo das unidades). Inclusive, dois deles (SC13 e SC05) apresentaram este tipo de resposta em 7 de 8 ocasiões.

No que diz respeito às crianças com escritas SSVSC observamos um predomínio de respostas não coordenadas (com somente uma resposta pertinente por letra); todos eles tiveram esse tipo de respostas (marcadas no intervalo das unidades). Essas, somadas às respostas N, são as que concentram a maior parte dos dados desse grupo de crianças.

Podemos concluir que a consistência nas respostas é incrementada conforme avança a conceitualização das crianças sobre o sistema de escrita. Tratando-se de crianças em processo de alfabetização, fica evidente, com a inconsistência de suas respostas, que seu leque de possibilidades para resolver as tarefas é limitado, assim como a relação que estabelecem entre identificar uma letra e poder usá-la (seja para escrever ou para completar uma palavra) não ocorre de maneira rápida ou imediata. Os dados nos sugerem que a generalização da informação faz parte das construções que as crianças fazem ao longo do processo de aprendizagem. 


\section{CAPÍTULO 4. CONCLUSÕES}

O modo tradicional de se considerar a escrita infantil consiste em se prestar atenção apenas nos aspectos gráficos dessas produções, ignorando os aspectos construtivos.

Ferreiro, 2010, p.21

O objetivo desse trabalho foi o de verificar a influência que a informação sobre o nome da letra tem para as crianças pré-alfabéticas nas decisões gráficas que elas tomam no momento de escrever uma palavra e de escolher qual letra completa uma palavra previamente escrita.

Para isso, desenhamos três tarefas nas quais as crianças precisavam (1) identificar letras fora de contexto, (2) escrever uma lista de palavras, e (3) completar palavras nas quais faltava a letra inicial. As palavras foram cuidadosamente escolhidas com o objetivo de que sua forma gráfica e/ou fonética não gerasse conflitos cognitivos para as crianças em momento inicial de reflexão sobre o sistema de escrita.

A tarefa de escrita de palavras teve duplo objetivo: servir para organizar a amostra segundo o momento conceitual e possibilitar a comparação da escrita da $1^{a}$ sílaba com as demais tarefas. As palavras ainda deveriam permitir observar se o contexto silábico motivado - quando há coincidência entre o som representado pela sílaba e o nome da letra que compõe sua representação - influencia no êxito da tarefa. Por essa razão, foram escolhidas quatro palavras cujas sílabas iniciais fossem motivadas fonologicamente e quatro palavras cujas sílabas iniciais fossem compostas pelas mesmas consoantes motivadas, mas com outro núcleo. Isso foi feito para que fosse usada uma letra potencialmente motivada, mas em contexto não motivado chamamos esse grupo de palavras de contraste. Além disso, escolhemos mais quatro sílabas em posição inicial nas quais o contexto silábico fosse não motivado, ou seja, composto por consoantes cujos nomes diferem de qualquer contexto silábico possível. O mesmo critério foi utilizado para a seleção das doze palavras da tarefa de completar palavras.

Os resultados obtidos mostram que, em relação à dificuldade das tarefas, identificar as letras fora do contexto foi a mais simples (71,79\% das respostas foram convencionais), enquanto completar pertinentemente o primeiro segmento das palavras escritas apresentou $54,17 \%$ das respostas.

$\mathrm{Na}$ tarefa de escrita de substantivos, em relação à representação do primeiro segmento silábico das palavras, $65,5 \%$ das respostas apresentaram a consoante convencional inicial (respostas CV pertinente $+\mathrm{C}$ pertinente). Sendo mais frequente a utilização da consoante pertinente para representar um segmento silábico "motivado" que outro "não motivado" ou de 
"contraste". Os "não motivados" foram os que tiveram maior quantidade de respostas não pertinentes e, por isso, podemos considerar essa tarefa como mais desafiadora para as crianças, inclusive mais que a escrita das sílabas do grupo de "contraste".

No entanto, é muito relevante destacar que as escritas mais convencionais (nas quais as crianças utilizavam tanto a consoante como a vogal para representar um segmento silábico inicial) ocorreram com mais frequência em sílabas "de contraste" ou "não motivadas". Ou seja, a presença da motivação da sílaba esteve relacionada com escritas menos avançadas (silábicas, que só utilizavam uma consoante).

Existe uma correlação constante e significativa entre o nível de conceitualização do sistema de escrita das crianças e a execução de todas as tarefas e este foi o aspecto que condicionou a possibilidade de uso das letras de modo pertinente nas tarefas de escrita e de completar palavras, bem como a exploração do contexto motivado.

Fora do contexto, as crianças demonstraram conhecer muitas letras, porém, esta informação não foi suficiente, sobretudo, para que as crianças com conceitualizações SSVSC pudessem completar ou escrever um segmento elegendo ao menos uma vogal pertinente. É dentro desse contexto de nível de escrita (SSVSC) que nosso argumento a respeito da transcendência explicativa da variável "conceitualização do sistema de escrita" tem maior relevância.

\subsection{Conclusões a partir das hipóteses do estudo}

A primeira hipótese que orientou este trabalho foi a de que o nível de conceitualização sobre o sistema de escrita apresentado pelas crianças (pré-alfabéticas) condiciona as suas possibilidades para identificar as letras pelo nome fora do contexto de leitura, para escrever e para completar palavras. Ou seja, quanto maior o nível de escrita, maiores são as suas chances de identificar letras, de escrever e de completar palavras.

Os resultados encontrados neste trabalho corroboram com a percepção, já destacada por diversos autores (Alvarado, 1997; Cano \& Vernon, 2008; E. Ferreiro, 2010; Emília Ferreiro, 1997, 2000, 2007; Vernon, 2001, 2005; Vernon et al., 2001; Zamudio, 2008), de que as crianças pré-alfabéticas, ou seja, que não consolidaram a aquisição do sistema de escrita, fazem análises progressivamente mais complexas sobre a linguagem escrita, formulam hipóteses e produzem escritas bastante pertinentes e reveladoras sobre as reflexões em processo. Também são capazes de identificar letras e partes que faltam em palavras escritas (Calderón, 2010; Cano \& Vernon, 2008; Fernández, 2015; Quinteros, 1994; entre outros). 
Os dados coletados nas três tarefas (escrita, completar palavras e identificar letras fora do contexto) confirmam que, efetivamente, quanto maior o nível de escrita, melhor é o desempenho nas referidas tarefas, mostrando que o nível de escrita é uma variável fundamental, pois amplia as possibilidades da criança em utilizar e integrar diferentes conhecimentos. Diferentemente do que sustenta a teoria cognitiva, pudemos demonstrar que as crianças em processo de alfabetização podem escrever e completar palavras apoiando-se em informações contextuais ou linguísticas, e não somente após completar o treinamento de identificação de letras e outros supostos pré-requisitos (Treiman \& Bowman, 2002, 2008).

A tarefa de identificar letras permitiu concluir que as crianças da amostra têm amplo conhecimento a respeito do nome das letras, já que $73,44 \%$ as identificaram de modo pertinente. No entanto, as identificações não foram estatisticamente equivalentes entre vogais e consoantes, sendo que as primeiras foram reconhecidas em $85,83 \%$ dos casos e as demais em 70,18\%.

Observamos também que conforme aumenta o nível de conceitualização sobre o sistema de escrita, amplia a possibilidade de reconhecer o nome das letras apresentadas, ou seja, a possibilidade de identificação de letras também esteve vinculada à reflexão que a criança faz do sistema de escrita.

Outro aspecto que também exerceu influência foram as características relacionadas à motivação fonológica (coincidência entre o nome da letra e o contexto silábico), pois os dados revelam que, estatisticamente, não foi equivalente identificar letras motivadas e letras não motivadas, sendo que estas últimas foram identificadas de forma pertinente com maior frequência.

Apesar de intuitivamente parecer mais fácil identificar letras cujos nomes coincidam com os respectivos fonemas que as representam - por exemplo, a letra T chama-se "te" e pronuncia-se /t/ -, os dados levantados e analisados nesta pesquisa permitem concluir que as letras que não têm essa motivação foram mais frequentemente identificadas. Ou seja, a motivação fonológica não foi um fator que exerceu influência.

Em relação à tarefa de escrita de palavras, as crianças também demonstraram bastante conhecimento, visto que $71,35 \%$ produziram escritas pertinentes para representar a $1^{\mathrm{a}}$ sílaba.

Enquanto as crianças com escrita SSVSC e SCVSC, no grupo de palavras de contraste e não motivadas, preferiram sistematicamente utilizar as vogais para a representação dos diferentes segmentos silábicos, as crianças SA usaram, majoritariamente, consoantes. Porém, no contexto motivado, a representação majoritária da sílaba, em todos os níveis conceituais, foi pela consoante. Portanto, a utilização da consoante ou da vogal ou a possibilidade de escrever 
a sílaba completa foram diretamente influenciadas pela motivação fonológica da sílaba a ser representada. Esse fenômeno foi observado tanto na tarefa de escrita quanto na de completar palavras, mas não implicou necessariamente na qualidade da escrita.

Se, por um lado, a sílaba motivada favorecia a seleção pela respectiva consoante, por outro, as sílabas de contraste e não motivadas favoreciam a utilização da vogal. Essa diferença entre os tipos de respostas não representa uma diferença qualitativa em relação à análise e à reflexão que a criança faz sobre o sistema de escrita.

Outro dado bastante interessante é que a maioria das respostas convencionais (a sílaba completa, ortograficamente correta) ocorreu em contextos de "contraste" e "não motivado".

Embora seja certo que a motivação das sílabas iniciais pôde fazer com que as crianças empregassem a consoante correspondente de maneira pertinente em sua representação, o esquema silábico motivou que o uso feito dessa consoante fosse igualmente silábico. Isto poderia nos levar a concluir sobre a utilidade dos segmentos motivados, embora a referida utilidade só tenha se apresentado entre as crianças com escritas SSVSC e SCVSC. Para as crianças com escritas mais avançadas, a utilidade do contraste que conseguiram fazer entre o nome da letra e dos segmentos não motivados foi maior, levando-os, inclusive, a apresentar respostas convencionais. Muitas crianças SA que foram capazes de utilizar a CV para representar sílabas de "contraste" e "não motivadas" usaram somente a consoante no contexto motivado, o que poderia significar uma "queda" em seu desempenho.

Essa consideração é importante porque relativiza o efeito da motivação ligada ao nome das letras para entender o avanço na compreensão do sistema de escrita. Portanto, a ideia defendida por Cardoso-Martins \& Batista (2005); Pollo et al. (2005b, 2015); Treiman \& Bowman (2002, 2008); Treiman et al. (2013), entre outros, de que o conhecimento do nome da letra é um importante pré-requisito para que as crianças possam escrever, não pôde ser confirmada neste estudo.

$\mathrm{Na}$ tarefa de completar palavras, as crianças apresentaram um desempenho inferior ao obtido nas demais tarefas, apresentando $54,17 \%$ de respostas pertinentes. No entanto, nessa tarefa, os critérios para considerar uma resposta como pertinente foram mais estritos - somente a letra convencional -, logo, todas as respostas que selecionavam a vogal correspondente como opção foram consideradas erradas. É importante destacar essa consideração, pois sabemos que muitas crianças silábicas apresentam maior percepção para o elemento vocálico da sílaba.

Observamos que nessa prova o contexto silábico motivado facilitou a localização da resposta pertinente, pois uma vez que a amostra era composta por crianças silábicas, ou seja, 
que já se deram conta da relação entre as partes que escutam e as partes grafadas, ao ouvirem e visualizarem a palavra escrita, rapidamente estabeleciam relação entre a parte buscada e seu correspondente oral, identificando qual segmento da palavra estava faltando. Como nas palavras motivadas o contexto silábico coincide com o nome da letra que o compõe, quando a criança sabia o nome da respectiva letra facilmente a selecionava para completar a palavra. Já nas palavras de contraste e não motivadas, o limite silábico, representado pela vogal, foi o que mais se destacou para as crianças, sendo, portanto, uma opção bastante considerada.

Vale ressaltar que no grupo de palavras de contraste, diferentemente do que ocorreu com as palavras iniciadas por sílabas motivadas, outra categoria de resposta que foi bastante representativa foi a da "vogal que compõe a sílaba", com $31,25 \%$ das respostas. Isso mostra que, apesar de muitas crianças conhecerem as consoantes "T", "P", "V" e "B", pois as utilizaram em contexto motivado, não puderam fazer o uso dessas mesmas letras em outra situação.

Observamos, portanto, que quanto maior o nível conceitual, maior a probabilidade demonstrada de generalizar a relação utilizada no contexto motivado para outros contextos. Isso se evidencia, pois as crianças com escritas SSVSC, apesar de utilizarem pertinentemente e com maior frequência as consoantes no contexto motivado, o que mostra que conhecem o valor sonoro da sílaba e da letra, não foram capazes de utilizá-las com a mesma frequência em contexto de contraste.

Contudo, embora todas as crianças, na tarefa de completar, tenham tido melhor desempenho no grupo de palavras motivadas, a diferença entre os grupos de palavras das crianças SA foi pouco significativa, pois apresentaram um desempenho equilibrado nos três grupos de palavras. Já para as crianças SSVSC e SCVSC, o índice de acertos nas palavras motivadas representou quase o dobro quando comparado aos demais.

A segunda e a terceira hipóteses deste estudo têm a ver com a generalização da possibilidade de uso de uma letra conhecida. Propomos que ( $2^{\text {a }}$ hipótese) conhecer o nome das letras pode facilitar que as crianças utilizem pertinentemente essa letra para escrever palavras (representar o segmento silábico inicial de uma palavra ditada); e que ( $3^{\text {a }}$ hipótese) conhecer o nome das letras facilita que as crianças identifiquem a letra inicial que completa a escrita de uma dada palavra.

Quanto a essas hipóteses, verificamos que ter a informação do nome da letra não implicou em poder utilizá-la para completar ou escrever palavras, e que, inclusive, poder utilizar essa informação em uma tarefa não implicou em poder utilizá-la em outra. 
Isso foi observável ao compararmos as respostas pertinentes obtidas em contextos motivados, tanto na tarefa de escrita como na de completar palavras, com as obtidas em contextos não motivados. Os dados revelaram que as crianças tinham conhecimento sobre o nome da letra e um possível uso, mas que essa possibilidade nem sempre foi generalizada e utilizada no contexto de sílabas de contraste. Ou seja, o uso do conhecimento do nome da letra variou em função das características fonológicas das sílabas escritas.

Vale destacar que, da lógica da criança, a sílaba só será motivada fonologicamente se ela souber os nomes das respectivas letras. Nesse sentido, vemos que o conhecimento do nome da letra teve bastante utilidade em contextos em que houve coincidência entre o nome da letra e o som emitido pela sílaba a ser representada, para que fosse feita a eleição pela consoante pertinente. No entanto, para a representação convencional da sílaba, no caso das crianças SA, os contextos não motivados (incluindo as sílabas de contraste) se mostraram mais eficazes para que a criança realizasse uma análise intrassilábica. Podemos concluir que se a coincidência entre o contexto motivado e o nome da letra por um lado favoreceu a escrita utilizando a respectiva consoante, por outro, prejudicou a possibilidade do registro mais conceitualmente avançado (CV).

O dado de que $74,6 \%$ das crianças SA que identificaram as letras tiveram condições de escrever convencionalmente a sílaba $(\mathrm{CV})$ no contexto de contraste corrobora com a ideia levantada anteriormente de que, para esse grupo conceitual, a motivação fonológica da sílaba não favoreceu o seu desempenho. Esses dados permitem a conclusão de que não foi o conhecimento do nome da letra e sua coincidência com o contexto silábico que possibilitou a escrita convencional, mas sim que o nível conceitual condiciona o uso que a criança pode fazer da informação dos nomes das letras.

Para as crianças SCVSC, as sílabas motivadas representaram uma possibilidade real de realizarem a escolha pela consoante, ao passo que as não motivadas as fizeram optar pela vogal que compunha a sílaba, ou seja, respostas igualmente pertinentes.

Os dados também sugerem que saber o nome convencional da letra não foi o fator determinante para garantir a pertinência da resposta. Isso porque, apesar de observarmos comportamentos de resposta que variavam em função da motivação fonológica, o denominador comum que implicava no incremento das respostas não foi saber ou não o nome da letra - visto que, em algumas análises realizadas, todas as crianças nos agrupamentos propostos sabiam os nomes das letras -, nem a coincidência com o contexto fonológico, mas sim o nível conceitual. 
Já nos agrupamentos organizados somente com as respostas das crianças que não identificaram as letras utilizadas na análise de completar e escrever palavras $(T, V, P, B, R, L$, $\mathrm{M} \mathrm{e} \mathrm{N}$ ), vimos também que as crianças que não identificaram as letras motivadas foram capazes de produzir representações pertinentes para a sílaba motivada em 38\% dos casos. Notamos que esse contexto silábico não foi favorável para que as crianças que não conheciam as respectivas letras produzissem escritas convencionais $(\mathrm{CV})$, mesmo no nível mais avançado de reflexão sobre o sistema. Esse é mais um dado que ajuda a corroborar a ideia de que não é o conhecimento isolado do nome da letra e nem tampouco o contexto silábico isoladamente que favorecem a produção de escritas convencionais - ou mesmo pertinentes, mas sim a possibilidade da criança de estabelecer relações entre a informação e sua utilidade em função dos diferentes contextos. A possibilidade de fazer essas relações é estreitamente ligada à reflexão que a criança pode fazer sobre os sistemas de escrita.

No nível SSVSC, houve 32 casos em que as letras motivadas não foram identificadas e em $84 \%$ das vezes as crianças produziram escritas não pertinentes. No entanto, na tarefa de completar palavras, o desempenho entre respostas pertinentes e não pertinentes esteve equilibrado (50\%). Esse dado chama a atenção, pois, na análise realizada entre as crianças que identificaram as letras motivadas, vimos que $62 \%$ das respostas para completar a sílaba foram pertinentes e levantamos a possibilidade de que o conhecimento do nome da letra tivesse influenciado o desempenho na tarefa nesse contexto fonológico. No entanto, observar que $50 \%$ das respostas foram pertinentes, embora fossem produzidas por crianças que não reconheceram as letras motivadas, ajuda a corroborar a hipótese de que o conhecimento isolado do nome da letra nem sempre é uma informação que a criança utiliza e tampouco de que necessita para realizar a tarefa de completar palavras em contextos motivados, nos quais há perfeita coincidência entre o nome da letra e o valor da sílaba.

As crianças que identificaram as letras motivadas também se mostraram bastante aptas para completar as palavras (83,33\%). Esse resultado também não surpreende, haja vista que as crianças desse nível conceitual (silábico) têm condições de fazer o recorte silábico da palavra. Como as sílabas iniciais desse grupo de palavras coincidiam com os nomes das letras, ao pronunciar a sílaba a criança dizia o nome da letra. Uma vez que ela é capaz de identificar as letras por seus nomes, localizá-las para completar as palavras desse grupo não representou um grande desafio. Vemos que mesmo entre as crianças SSVSC, das 29 que identificaram a letra por seu nome, $62 \%$ puderam utilizá-la para completar palavras. 
Por fim, a última hipótese desse trabalho era a de que o nível de escrita condiciona a utilidade que o conhecimento do nome da letra representa para a criança ao escrever ou completar palavras escritas.

Ao longo da discussão das hipóteses anteriores foi ficando evidente a influência da reflexão que a criança tem sobre a escrita com relação ao uso de dados contextuais e linguísticos em suas produções escritas ou para completar palavras.

$\mathrm{Na}$ última etapa de análise dos dados, no Capítulo 3, ao realizarmos a correlação entre identificar, escrever e completar palavras, observamos que a possibilidade de coordenar as informações e os contextos e ter respostas mais consistentes também se deu em função do nível de conceitualização.

$\mathrm{Na}$ análise das respostas organizadas em dois grupos, (1) um composto pelas crianças que identificaram as letras analisadas e (2) outro pelas crianças que não identificaram as letras analisadas, vimos que entre as crianças do grupo 1, apesar de todas terem identificado o nome da letra, isso não foi suficiente para que produzissem escritas ou as completassem de maneira pertinente. $\mathrm{O}$ incremento nas respostas pertinentes ocorreu de acordo com o nível conceitual: quanto maior o nível, maior a quantidade de respostas pertinentes.

Os achados encontrados neste estudo permitiram confirmar que antes de escrever convencionalmente as crianças possuem informações sobre quais são as letras e como se chamam. Porém, a utilidade dessa informação parece diferir em função da tarefa que lhes é solicitada (escrever ou completar uma palavra), dos contextos silábicos que atendem, e, sobretudo, da conceitualização que construíram sobre o sistema de escrita. Ou seja, crianças em idades semelhantes podem apresentar maior ou menor informação sobre o sistema de escrita, mas a possibilidade de usar essas informações está condicionada pela conceitualização que elas já construíram a respeito desse sistema. Nesse sentido, crianças com escrita SSVSC, apesar de terem um conhecimento amplo sobre a nomeação convencional das letras, não conseguiam utilizá-lo pertinentemente no momento de escrever.

\subsection{Resultados contrastantes com a perspectiva cognitivista}

Foi foco deste estudo analisar a influência que a informação sobre o nome da letra tem para as crianças pré-alfabéticas nas decisões gráficas tomadas por elas. A escolha por este recorte se deu em função da crença, muito recorrente na educação brasileira, sobre este ser um pré-requisito para a alfabetização. 
Os resultados encontrados corroboram as hipóteses levantadas neste estudo - de que a possibilidade de utilizar e integrar diversas informações, no caso o conhecimento do nome da letra, depende do nível conceitual da criança -, e estão alinhados a diversas pesquisas qualitativas oriundas da psicolinguística e da didática. No entanto, os estudos de natureza cognitiva chegam a resultados distintos em relação à importância que a informação tem para a aquisição da língua escrita, em decorrência de diferenças epistemológicas estruturais na forma de conceber o sistema de escrita, a aprendizagem e a criança.

Em relação à concepção sobre o sistema de escrita, os trabalhos revisados de natureza cognitivista não apresentaram critérios claros e coerentes para a escolha das palavras a serem ditadas, ou seja, não apresentam justificativa linguística para a escolha das palavras.

No entanto, a perspectiva da psicologia genética já demonstrou em inúmeras pesquisas que a extensão da palavra e a variação do núcleo e do ataque silábico impactam significativamente na qualidade da produção gráfica. A escrita de monossílabos e dissílabos bem como a de palavras que repetem o núcleo e o ataque silábico representam grande desafio conceitual para a criança em momento inicial de alfabetização, pois geram conflitos cognitivos com as hipóteses já consolidadas que elas têm sobre o sistema de escrita.

Neste sentido, é esperado, portanto, que ao terem que escrever palavras com estas características, sua produção não revele, isoladamente, a análise que já podem fazer sobre a língua escrita. Diante destas produções, as crianças poderiam acrescentar mais letras para completar a configuração gráfica e cumprir com os critérios de legibilidade; inserir uma letra não pertinente no lugar de outra que sabe que é pertinente para garantir o critério de variabilidade, entre outros. Por isso, o critério de escolha de palavras é condição primeira para que seja possível controlar e analisar as escritas infantis.

As pesquisas de corte cognitivista também não consideram as características fonológicas do idioma analisado, propondo escritas de palavras compostas por sílabas ou letras com diferentes possibilidades de realização sonora no português, o que impacta fortemente na produção, sobretudo, quando a natureza do erro não é observada.

A não consideração destes aspectos não são meros lapsos, mas sim coerências com a concepção que se tem sobre a escrita, ou seja, que esta é um código que serve para transcrever a linguagem oral, sendo a palavra uma mera sequência de letras ou de fonemas. Naturalmente, os resultados encontrados serão distintos daqueles estudos que considerem a língua escrita não como um código, mas como um sistema de representação, cujas características influenciam nas 
hipóteses que as crianças formulam sobre seu funcionamento, nas decisões que tomam no momento de escrever, e que tem particularidades em função do idioma em que é investigado.

Outro entrave epistemológico diz respeito à concepção que se tem das possibilidades infantis. Para as autoras de posicionamento cognitivista não importa o que as crianças sabem previamente, o que pensam sobre a linguagem escrita, suas funções e funcionamentos. $\mathrm{O}$ indivíduo é uma tabula rasa e tudo o que sabe é fruto da instrução, da transmissão direta realizada pelo adulto, que é quem detém o saber. Neste sentido, é inconcebível que a criança realize suas próprias análises sobre o escrito e formule ideias, ainda que provisórias.

Por esta razão, uma diferença crucial entre as pesquisas de origem cognitiva e as de origem psicogenéticas, que impacta fortemente nos resultados encontrados, diz respeito a observação de como as crianças vão, uma a uma, construindo a escrita da palavra, bem como as justificativas (verbalizações) que dão para esta produção: é abissal a diferença conceitual entre escrever "BOLA", colocando as letras "TJUONG" de forma aleatória, e escrever "TJ", atribuindo cada letra para cada sílaba da palavra, e, em seguida, acrescentar outras letras, porque "duas letras é pouco para que se possa escrever".

Ou seja, não se reconhece a ação cognitiva das crianças, nem que as diferentes escritas são respostas que elas dão ao tentar resolver um problema, que é escrever, antes de poder fazêlo convencionalmente.

Desta concepção de objeto de ensino (a língua escrita) e da concepção do sujeito de aprendizagem decorrem a forma de entender o processo de aprendizagem e o papel atribuído à informação externa.

As pesquisadoras da linha da aprendizagem estatística, embora rompam com premissas que sustentavam a produção de natureza cognitivista - sobre a defesa da consciência fonológica como pré-requisito para a alfabetização, reconhecendo que esta, ao contrário, é resultado da alfabetização -, passam a sustentar que é o conhecimento do nome da letra que possibilita que a criança perceba a relação, unívoca, entre a parte que se escuta e sua respectiva marca gráfica.

Desta forma, não há mudança conceitual na maneira de entender a aprendizagem - a diferença reside apenas que, em uma perspectiva acredita-se que a consciência fonológica é um pré-requisito para a alfabetização, e em outra, o pré-requisito é o conhecimento do nome da letra - o que muda é a variável que é considerada.

Com isso, pressupõem-se que para cada letra exista apenas um nome, o que, dadas as características do português, não é verdade. Considera-se também que a aprendizagem dependa exclusivamente da informação e, portanto, que todo conhecimento da criança provém da 
instrução, logo, o conhecimento gerado pela ação estruturante do sujeito não existe. Consequentemente, é inconcebível, nesta perspectiva, que as crianças formulem hipóteses sobre a escrita e que estas possam ser pertinentes e as ajudem a compreender o sistema de escrita e a avançar em sua reflexão sobre ele. Como tudo o que a criança produz é fruto do ensino e, consequentemente, como ninguém ensinou a escrever uma letra por sílaba, um sinal gráfico por sílaba, a criança não poderia, então, apresentar uma produção considerada silábica.

Por esta razão, estas mesmas pesquisas têm defendido que as crianças brasileiras não passam por um momento do desenvolvimento da escrita em que escrevem silabicamente, mas que usam em suas escritas as letras que observam com maior frequência de aparição em textos infantis ou as letras cujos nomes reconhecem na emissão oral. Desta percepção decorre a importância que atribuem ao ensino do nome da letra, porque é a partir deste conhecimento que elas poderão passar a identificá-lo auditivamente e a transcrevê-lo para o papel. Contraditoriamente, estas próprias pesquisas têm dados que mostram que mesmo as crianças que conhecem os nomes das letras, não puderam usar este conhecimento para escrever.

No entanto, dado que as pesquisadoras não acompanham a produção das crianças, não observam a construção da escrita, nem como elas justificam o que escreveram, limitando a análise apenas ao resultado gráfico; como deixam as crianças por si mesmas e em muitas ocasiões nem sequer dizem oralmente a palavra que solicitam que seja escrita; como não consideram nas palavras solicitadas os desafios impostos por cada uma delas (monossílabos, dissílabos, sílabas complexas, repetição do núcleo e do ataque silábico), e nem tampouco as características próprias de cada idioma, fica realmente difícil que observem uma produção silábica consistente.

A natureza da própria investigação dificulta, senão impede, que este tipo de escrita apareça, pois não é uma investigação que se interessa pelo processo de construção da escrita, nem pelas formulações e reflexões infantis.

Embora estas pesquisas considerem a perspectiva psicogenética como a "teoria influente no Brasil", o que vemos no nosso cenário educacional é que embora esta tenha impactado fortemente os documentos curriculares nacionais e os documentos curriculares escolares, muito pouco se conseguiu consolidar consistentemente na prática das salas de aula.

Há cerca de 40 anos que as pesquisas de Ferreiro e Teberosky (1999) chegaram ao país e ainda hoje encontramos inúmeras assimilações deformantes e falas equivocadas a respeito. Considerações que atribuem orientações didáticas à pesquisa psicogenética; que atribuem ao arcabouço teórico construtivista a defesa de que a aprendizagem ocorre simplesmente na 
interação espontânea da criança com diferentes objetos, diminuindo a importância do trabalho docente; que nesta perspectiva não se corrigem os erros das crianças; e a utilização dos momentos conceituais de reflexão sobre o sistema de escrita apenas para avaliar e ranquear as crianças e não como ferramentas para planejar de forma ajustada propostas didáticas e e de acompanhamento das aprendizagens.

Ainda há muito o que avançar, sobretudo no que diz respeito a uma das principais contribuições de Ferreiro (1982, 1997, 1999, 2000, 2002, 2007, 2009, 2010, 2013, entre outros), presente em suas inúmeras pesquisas e publicações: o acesso à cultura escrita como direito de todos, por seu potencial transformador para superar contextos desfavoráveis de vida.

$\mathrm{Na}$ contramão disso, encontram-se as metodologias ligadas à psicologia cognitiva, que, como referido anteriormente, desconsideram os sujeitos da aprendizagem, seus processos de aprender e mesmo o objeto de ensino: a Língua Portuguesa, com características que lhe são particulares.

Por isso, esta pesquisa desejou refutar algumas das premissas cognitivistas - no que se refere ao conhecimento do nome da letra como pré-requisito para a alfabetização, mas também reafirmando que as crianças passam por um momento conceitual silábico, no qual formulam a hipótese de que para escrever usa-se uma letra para cada segmento oral identificado (a sílaba), e, sobretudo, reafirmando a importância dos momentos conceituais para a reflexão que as crianças fazem sobre o sistema de escrita e sobre a possibilidade que têm para utilizarem as informações que dispõem.

\subsection{Implicações pedagógicas do estudo}

Apesar dos quase 40 anos da primeira publicação da Psicogênese da Língua Escrita, na qual Ferreiro \& Teberosky (1999) propunham uma nova forma de conceber a aprendizagem da leitura e da escrita, o pressuposto teórico que continua embasando a grande maioria das propostas didáticas é o mesmo que fundamentava as práticas anteriores a essa descoberta.

O problema é que nesse modelo o foco das propostas reside apenas no objeto da aprendizagem, no caso, a língua, não considerando os sujeitos da aprendizagem - as crianças. A análise da língua como um objeto, partindo da lógica e das possibilidades de análise do adulto, e que, portanto, só pode fazê-lo por já ser alfabetizado, implica em não considerar a lógica infantil, os objetos que a criança está tentando desvendar, as relações particulares que vai desenvolvendo e as hipóteses provisórias que formula na tentativa de explicar aquilo que observa. Ao considerar as crianças a partir dessa perspectiva, não faz sentido a formulação 
antecipada de etapas de aprendizagem a serem percorridas de maneira coletiva sob o pressuposto de que todas estão no mesmo momento, com as mesmas possibilidades e mesmos interesses.

Uma das ideias do modelo cognitivista que mais marcaram as práticas de aula na alfabetização inicial é a de que saber os nomes das letras é uma condição sin ne qua non, ou seja, para aprender a ler e a escrever as crianças devem reconhecer e nomear todas as letras de seu idioma. As principais implicações dessa formulação são (1) a quantidade de brinquedos destinados a crianças desde o nascimento até os 7 ou 8 anos de idade, em que se privilegia somente o conhecimento dos nomes das letras (e também dos números) em detrimento de outros aspectos da cultura, como as cantigas, os contos, as brincadeiras de roda etc., próprios da tradição popular; (2) propostas pedagógicas que dedicam muito tempo didático ao ensino do alfabeto e, pior, acredita-se que com isso se esteja ensinando a "Língua Portuguesa" ou a "Linguagem Oral e Escrita" - como é conhecida a disciplina escolar responsável pelos conteúdos dessa área de saber. Às vezes, por não se saber trabalhar essa área com crianças pequenas - porque um dos efeitos dessa perspectiva é a crença nas poucas possibilidades das crianças -, foca-se todo o trabalho da Educação Infantil no ensino da grafia, traçado, nome e "respectivo" fonema, sem sequer considerar-se as inúmeras possibilidades de realização sonora das letras.

Dessa maneira, as contribuições teóricas mais importantes deste trabalho são:

1. A reafirmação do papel estruturante dos níveis conceituais como organizadores das informações contextuais e linguísticas às quais as crianças estão expostas e sobre as quais fazem diferentes aproximações. É a partir dos esquemas de equilibração da criança e de seus conhecimentos já construídos que ela assimilará e acomodará as informações que o meio vai lhe oferecer. Também a reafirmação de que a criança pré-alfabética brasileira passa por um momento em que acredita na hipótese de que a linguagem que consegue escutar é formada por segmentos menores, as sílabas, e que a segmentação da palavra que pode fazer oralmente é representada por uma marca gráfica, e que isso é escrever.

2. A possibilidade de fazer uso da informação fornecida pela língua ou pelos contextos de produção está condicionada pelas reflexões que a criança pode fazer sobre o sistema de escrita, ou seja, por seus níveis conceituais. Nesse sentido, saber o nome das letras pode ser útil a determinadas crianças, em determinados contextos de produção (escrever ou completar palavras), e em determinados contextos linguísticos (a depender do tipo de sílabas que representará - motivadas ou não motivadas), mas pode não ser útil a outras crianças, em 
condições diferentes, e, mais ainda, pode inclusive configurar-se, para algumas crianças, em um elemento que dificulta a produção. 


\section{REFERÊNCIAS BIBLIOGRÁFICAS}

Acordo Ortográfico da Língua Brasileira. Disponível em $<$ https://www.academia.org.br/nossalingua/vocabulario-ortografico $>$ acessado em 17/06/2017.

Alvarado, M. (1997). Conciencia fonológica y escritura de niños preescolares: la posibilidad de omitir el primer segmento (Tesis de Maestria). Universidad Autónoma de Querétaro, México.

Alves-Martins, M., \& Silva, C. (1999). O nome das letras e a fonetização da escrita. Análise Psicológica, 1 (17), 49-63.

Borzone, A. M., \& Signorini, A. (1988). Del habla a la escritura. La conciencia linguística como una forma de transición natural. Lectura Y Vida, 9/2, 5-9.

Bryant, P., \& Bradley, L. (1987). Problemas de leitura na criança. Porto Alegre: Artes Médicas.

Calderón, G. (2010). La hipótesis alfabética y la conciencia fonológica en niños de preescolar. In G. Calderón \& K. Hess, El reto de la lengua escrita en la escuela. México: FUNDAp.

Calderón, Gabriela. (2004). Análisis de lo oral y conocimiento del sistema de escritura en niños preescolares: un enfoque cualitativo (Tesis de Maestria). Universidad Autónoma de Querétaro, Querétaro, México.

Cano, S., \& Vernon, S. (2008). Lo que los niños saben de las letras antes de comenzar a escribir convencionalmente. (Tesis de Maestria). Universidad Autónoma de Querétaro, México.

Cardoso-Martins, C., \& Batista, A. C. E. (2005). O conhecimento do nome das letras e o desenvolvimento da escrita: Evidência de crianças falantes do português. Psicologia: Reflexão \& Crítica, 18 (3), 330-336.

Cardoso-Martins, C., Resende, S. M., \& Rodrigues, L. A. (2002). Letter name knowledge and the ability to learn to read by processing letter-phoneme relations in words: Evidence from Brazilian Portuguese-speaking children. Reading and Writing, 15, 409-432.

Cardoso-Martins, Cláudia. (2001). The Reading Abilities of Beginning Readers of Brazilian Portuguese: Implications for a Theory of Reading Acquisition. Scientific Studies of Reading, 5, 289-317.

Castedo, M. (1997). A função alfabetizadora da escola, hoje. In Seminário Internacional Projetos didáticos com língua escrita. São Paulo: Centro de Estudos Escola da Vila.

Castedo, Mirta, \& Torres, M. (2012). Un panorama de las teorías de la alfabetización en América Latina durante las últimas décadas (1980-2010). In R. P. (coord ) Spregelburg (Org.), Historia de la Lectura en la Argentina. Del catecismo colonial a las netbooks estatales (p. 615668). Buenos Aires: Editoras del Calderón.

Colello, S., \& Luize, A. (2006). Aventura Linguística. Viver - Mente e Cérebro (coleção Memória da Pedagogia), 5(n.5), 14-23.

Delfior, S. (2008). ¿Cómo facilitar el aprendizaje inicial de la lectoescritura? Papel de las habilidades fonológicas. Infancia y aprendizaje, 31 \{3), 333-345. 
Ehri, L. (1986). Sources of difficulty in learning to spell and read. In D. Routh (Org.), Advances in developmental and behavioral pediatrics (p. 121-195). Hillsdale: Erlbaum.

Ehri, L. C. (1998). Grapheme-phoneme knowledge is essential for learning to. In L. C. Ehri (Org.), Word recognition in beginning literacy (p. 3-40). Mahwah: Erlbaum.

Fernández, N. (2015). El efecto del rasgo de continuidad en la identificación de palabras escritas (Tesis de doutorado). Universidad Autónoma de Querétaro, México.

Ferreiro, Emília, Gómez Palacios, M., \& Colaboradores. (1982). Análisis de las Perturbaciones en el Proceso de Aprendizaje de la Lecto-Escritura. In Fascículo 4: Las Relaciones entre el Texto -como Totalidad-y sus Partes. México.

Ferreiro, Emília. (1997). Alfabetización. Teoría y práctica. México: Siglo XXI.

Ferreiro, Emília, \& Teberosky, A. (1999). Psicogênese da Língua Escrita. Porto Alegre: Artmed.

Ferreiro, Emília. (2000). Entre la sílaba oral y la palabra escrita. Infancia y Aprendizaje, 89, $25-37$.

Ferreiro, Emília. (2002). Relaciones de (in) dependencia entre oralidade y escritura. Barcelona: Gedisa.

Ferreiro, Emília. (2007). Las unidades de lo oral y las unidades de lo escrito. Archivos de Ciencias de la Educación, 1 (1 cuarta época)(Universidad de La Plata, Argentina), 195-230.

Ferreiro, Emília (2008). Pasado y presente de los verbos leer y escribir - $2^{\mathrm{a}}$ ed. - Buenos Aires: Fondo de Cultura Económica.

Ferreiro, Emília. (2009). The transformation of children's knowlwedge of language units during beginning and initial literacy. In Y. Goodman \& J. Hoffman, Changing literacies for changing times (p. 61-75). Nova York: Routledge.

Ferreiro, E. (2010). Reflexões sobre alfabetização. São Paulo: Cortez.

Ferreiro, Emília, \& Ferreiro, E. (2013). La desestabilización de las escrituras silábicas: alternancias y desorden con pertinencia. In El ingreso a la escritura y las culturas de lo escrito (p. 47-55). México: Siglo XXI.

Frith, U. (1985). Beneath the surface of developmental dyslexia. In J. Marshall (Org.), Surface dyslexia: Neuropsychological and cognitive studies of phonological reading (p. 301-330). Hillsdale, NJ: Lawrence Erlbaum.

Frost, R., Katz, L., \& Bentin, S. (1987). Strategies for Visual Word Recognition and Orthographical Depth: A Multilingual Comparison. Journal of Experimental Psychology: Human Perception and Performance, 13, 104-115.

Gentry, J. R. (1982). An analysis of developmental spelling in Gnys at wrk. The Reading Teacher, 36, 192-200.

Goodman, N. (1976). Languages of Art: an approach to a theory of symbols. Indianapolis/Cambridge: Hackett. 
Goswami, U., Gombert, J. E., \& De Barrera, L. F. (1998). Children's orthographic representation and linguistic transparency: Nonsense word reading in English, French and Spanish. Applied Phsycholinguistics, 19, 19-52.

Goswami, U., \& Ziegler, J. (2005). Reading Acquisition, Developmental Dislexia and Skill Readers Across Languages: A Psycholinguistic Grain Size Theory. Phsycological Bulletin, 131(1), 3-9.

Harris, R. (1986). The origin of writing. London: Gerald Duckworth.

Leal, F., Matute, E., \& Zarabozo, D. (2005). La transparencia del sistema ortográfico del español de México y su efecto en el aprendizaje de la escritura. Estudíos de Linguística Aplicada, 42, 127-145.

Liberman, I. Y., Shankweiler, D., Fischer, F. W., \& Carter, B. (1974). Explicit syllable and phoneme segmentation in the. Journal of Experimental Child Psychology, 18, 201-212.

Lourenço, C., \& Alves Martins, M. (2010). Evolução da Linguagem Escrita no Pré-Escolar. In Actas do VII Simpósio Nacional de Investigação em Psicologia (p. 2749-2762). Minho, Portugal: Universidade do Minho.

Marques, L. F. (2008). Estrutura silábica do português do Brasil: uma análise tipológica. São Paulo, SP, Brasil: Universidade São Paulo.

Olson, D. (1988). A escrita e a mente. In ALVAREZ (Org.), Estudos socioculturais da mente (p. 89-111). Porto Alegre: Artes Médicas.

Piaget, J. (1967). Seis estudos de psicologia. Rio de Janeiro: Forense.

Piaget, J. (1971). A epistemologia genética. Petrópolis: Vozes.

Piaget, J. (1972). Problemas de psicologia genética. Petrópolis: Vozes.

Piaget, J. (1973). Para onde vai a educação? Rio de Janeiro: Editora/Unesco.

Piaget, J. (1977). O desenvolvimento do pensamento: equilibração das estruturas cognitivas. Lisboa: Dom Quixote.

Piaget, J. (1978). O nascimento da inteligência na criança. Rio de Janeiro: Zahar.

Pollo, T., Kessler, B., \& Treiman, R. (2005a). Vowels, syllables, and letter names:Differences between young children s spelling in English and Portuguese. Experimental Child Psychology, 92, 161-181.

Pollo, T., Kessler, B., \& Treiman, R. (2005b). Vowels, syllables, and letter names:Differences between young children $\mathrm{s}$ spelling in English and Portuguese. J. Experimental Child Psychology, 92, 161-181.

Pollo, T., Treiman, R., \& Kessler, B. (2008). Three perspectives on spelling development. In A. Naples (Org.), Single word reading: Cognitive, behavioral and biological perspectives ( $\mathrm{p}$. 175-189). Mahwah, N. J: Erlbaum.

Pollo, T., Treiman, R., \& Kessler, B. (2015). Uma revisão crítica de três perspectivas sobre o o desenvolvimento da escrita. Estudos de Psicologia (Campinas), 32(3), 449-459. 
Quaresma, P., \& Pinho, A. (2007). Análise de Frequências da Língua Portuguesa. In Livro de Actas da Conferência Ibero-Americana InterTIC (p. 267-272). Porto.

Quinteros, G. (1994). El uso y función de las letras en el período pre-alfabético. Lectura y Vida, ano 15(4). Recuperado de http://www.lecturayvida.fahce.unlp.edu.ar/numeros/a15n4/15_04_Quinteros.pdf

Quinteros, G. (1997). El uso y función de las letras en el periodo pre-alfabético (Tesis de Maestria). DIE, CINVESTAV-IPN, México.

Read, C., \& Treiman, R. (2013). Children's invented spelling: What we have learned in forty years. In R. C. Berwick (Org.), Rich languages from poor inputs (p. 197-211). New York: Oxford University Press.

Sampson, G. (1997). Sistemas de escritura. Análisis lingüistico. Barcelona: Gedisa.

Scarpa, R. L. P. (2014). O conhecimento de pré-escolares sobre a escrita: impactos de propostas didáticas diferentes em regiões vulneráveis (Tesis de doutorado). Universidade de São Paulo, São Paulo. Recuperado de http://www.teses.usp.br/teses/disponiveis/48/48134/tde20102014-115756/pt-br.php

SEYMOUR, P. H. K., ARO, M., \& ERSKINE, J. M. (2003). Foundation literacy acquisition in European orthographies. British Journal of Psychology, 143-174.

Signorini, A. (1988). La conciencia fonológica y la lectura. Teoría e investigación acerca de una relación compleja. Lectura y vida, 19, 15-22.

Silva, T. C. (2003). Fonética e Fonologia do Português: roteiro de estudos e guia de exercícios.

Sinclair, H. (1990). A produção de notações na criança: linguagem, número, ritmos e melodias. São Paulo: Cortez.

Teberosky, A., \& Tolchinsky, L. (2008). Além da Alfabetização. São Paulo: Ática.

Teberosky, Ana, \& Martinez, O. (2003). El nombre de las letras. Lectura y Vida, 24(3).

Treiman, R. (1994). Use of consonant letter names in beginning spelling. Developmental Psychology, 30 (4), 567-580.

Treiman, R. (1998). Why spelling? The benefits of incorporating spelling into beggining reading instruction. In L. C. Ehri (Org.), Word recognition in beggining (p. 289-313). Mahwah, N.J: Erlbaum.

Treiman, R. (2004). Phonology and spelling. In T. Nunes (Org.), Handbook of children's literacy (p. 31-42). Dordretch, the Netherlands: Kluwer.

Treiman, R., \& Bowman, M. (2002). Relating print and speech: The effects of letter names and word position on reading and spelling performance. Journal of Experimental Child Psychology, $82,305-340$.

Treiman, R., \& Bowman, M. (2008). Are young children logographic readers and spelleres? Scientific Studies of Reading, 12, 185-202. 
Treiman, R., Pollo, T., Cardoso-Martins, C., \& Kessler, B. (2013). Do young children spell words syllabically? Evidence from learners of Brazilian Portuguese. J Exp Child Psychol, 116 (4), 873-890.

Treiman, R., \& Rodríguez, K. (1999). Young children use letter names in learning to read words. Psychological Science, 10, 334-338.

Treiman, R., Sotak, L., \& Bowman, M. (2001). The role of letter names and letter sounds in connecting print and speech. Memory \& Cognition, 29, 860-873.

Treiman, R., Weatherstone, S., \& Berch, D. (1994). The role of letter names in children's learning of phoneme-grapheme relations. Applied psycholinguistics, 15, 97-122.

Vernon, S. (1997a). El proceso de construcción de la correspondencia sonora en la escritura (en la transición entre los periodos pre-silábicos y el silábico) (Tesis de doutorado 6). DIE, CINVESTAV-IPN, México.

Vernon, S. (1997b). La relación entre la conciencia fonológica y los niveles de conceptualización de la escritura (Tesis de doutorado). DIE, CINVESTAV-IPN, México.

Vernon, S. (2001). La identificación de letras, la conciencia fonológica y el desarrollo de la escritura en niños preescolares. Apresentado em Memorias del $2^{\circ}$ Simposio Internacional de "Lectura y Vida", Buenos Aires: IRA.

Vernon, S. (2005). La relación entre la conciencia fonológica y los niveles de conceptualización de la escritura (Tesis de doutorado). DIE, CINVESTAV-IPN, México.

Vernon, S., Alvarado, M., \& Calderón, G. (2001, julho). La conciencia fonológica y el proceso de adquisición de la lengua escrita: Resultados de dos estudios en español. Psicología y Sociedad, Revista semestral de la Facultad de Psicología, (Ed Especial).

Vernon, S., \& Calderón, G. (1999). Letras y sonidos en la alfabetización inicial. In Cuaderno de trabajo. Sistema de Investigación Miguel Hidalgo. Querétaro, México: Consejo Nacional de Ciencia y Tecnología.

Zamudio, C. (2004). Las ideas infantiles sobre la separación de las palabras. In A. Pellicer \& S. Vernon, Enseñar la lengua escrita en la escuela (p. 71-95). México: SM Editores.

Zamudio, C. (2008). Influencia de la escritura alfabética en la segmentación de sonidos vocálicos y consonánticos. Lectura y Vida, 29 (1), 10-21. 